Florida International University FIU Digital Commons

$11-6-2014$

\title{
Hispanic Orientalism: The Literary Development of a Cultural Paradigm, from Medieval Spain to Modern Latin America
}

Svetlana V. Tyutina

Florida International University, svetatyutina@yahoo.com

DOI: $10.25148 /$ etd.FI14110717

Follow this and additional works at: https://digitalcommons.fiu.edu/etd

Part of the Latin American Languages and Societies Commons, Latin American Literature

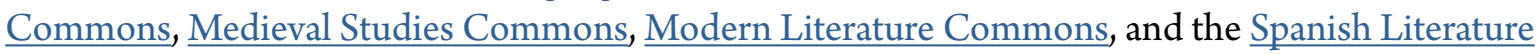
Commons

\section{Recommended Citation}

Tyutina, Svetlana V., "Hispanic Orientalism: The Literary Development of a Cultural Paradigm, from Medieval Spain to Modern Latin America" (2014). FIU Electronic Theses and Dissertations. 1592.

https://digitalcommons.fiu.edu/etd/1592 


\section{FLORIDA INTERNATIONAL UNIVERSITY}

Miami, Florida

\section{HISPANIC ORIENTALISM: THE LITERARY DEVELOPMENT OF A CULTURAL}

PARADIGM, FROM MEDIEVAL SPAIN TO MODERN LATIN AMERICA

A dissertation submitted in partial fulfillment of

the requirements for the degree of

DOCTOR OF PHILOSOPHY

in

SPANISH

by

Svetlana Tyutina

2014 
To: Interim Dean Michael R. Heithaus

College of Arts and Sciences

This dissertation, written by Svetlana Tyutina, and entitled Hispanic Orientalism: The Literary Development of a Cultural Paradigm, from Medieval Spain to Modern Latin America, having been approved in respect to style and intellectual content, is referred to you for judgment.

We have read this dissertation and recommend that it be approved.

Maida Watson

Joan Torres-Pou

Maya Boutaghou

Jean Rahier

Erik Camayd-Freixas, Major Professor

Date of Defense: November 6, 2014

The dissertation of Svetlana Tyutina is approved.

Interim Dean Michael R. Heithaus

College of Arts and Sciences

Dean Lakshmi N. Reddi

University Graduate School

Florida International University, 2014 
C Copyright 2014 by Svetlana Tyutina

All rights reserved.

"Cantar de mio Cid: Creation of the Founding Paradigm of Hispanic Orientalism" is published with the permission of Cambridge Scholar Publishing. 


\section{DEDICATION}

In loving memory of Ekaterina and Boris Venediktov. You have left this world too early, but you will be always in my heart. 


\section{ACKNOWLEDGMENTS}

I would like to thank my family and friends for their supports, patience, and understanding during this long journey. Their help and positive attitude allowed me to stay focused on my final goals at all times. I am especially grateful for the support of my father and husband who encouraged me to pursue my dreams and helped me to draw a road map to get there.

I also wish to thank the members of my dissertation committee for their invaluable advice and assistance during my doctoral studies. Their guidance helped me to succeed in my studies, as well as take advantage of leadership opportunities in the field of modern languages and higher education administration. I would give thanks to Dr. Maida Watson in particular for her constant support and encouragement of my endeavors and her active involvement with Modern Languages Graduate Student Organization that I founded and chaired since 2007. I am thankful to Dr. Ignacio López-Calvo and Dr. Cristián Ricci from University of California at Merced for introducing me to the exiting international community of Orientalists.

Finally, I would like to thank my major professor, Dr. Erik Camayd-Freixas, who from the beginning had confidence in my abilities to not only to successfully carry out my research, but also to become a professional in my field. Without his understanding, support and timely advice I would not be able to achieve everything I did during my doctoral studies.

In conclusion, I would like to thank Florida International University Graduate School for their financial support of my research and studies through Teacher Assistantship, Dissertation Evidence Acquisition Fellowships, and Dissertation Year 
Fellowship. I am also thankful to the Morris and Anita Broad Foundation and the Center for International Business Education and Research for awarding me research fellowships to collect data for my project in the United States and abroad. 


\title{
ABSTRACT OF THE DISSERTATION \\ HISPANIC ORIENTALISM: THE LITERARY DEVELOPMENT OF A CULTURAL PARADIGM, FROM MEDIEVAL SPAIN TO MODERN LATIN AMERICA
}

by

\author{
Svetlana Tyutina \\ Florida International University, 2014 \\ Miami, Florida \\ Professor Erik Camayd-Freixas, Major Professor
}

This dissertation offers a novel approach to Hispanic Orientalism, developing a dynamic paradigm from its origins in medieval and Renaissance Iberia during the process of the Christian Reconquest, to its transatlantic migration and establishment in the early years of the Colony, from where it changed in late colonial and post-Independence Latin America, and onto modernity.

The study argues that Hispanic Orientalism does not necessarily imply a negative depiction of the Other, a quality associated with the traditional critique of Saidian Orientalism. Neither, does it entirely comply with the positivist approach suggested in the theoretical research of Said's opponents, like Julia Kushigian. This dissertation also argues that sociopolitical changes and the shift in the discourse of powers, from imperial to non-imperial, had a significant impact of the development of Hispanic Orientalism, shaping the relationship with the Other.

The methodology involves close reading of representative texts depicting the interactions of the dominant and dominated societies from each of the four historic periods that coincided with significant sociopolitical transformations in Hispanic society. 
Through an intercultural approach to literary studies, social history, and religious studies, this project develops an original paradigm of Hispanic Orientalism, derived from the image of the reinvented Semitic Other portrayed in the literary works depicting the relationship between the hegemonic and the subaltern cultures during the Reconquest period in Spain. Then, it traces the turn of the original paradigm towards reinterpretation during its transatlantic migration to Latin America through the analysis of the chronicles and travelogs of the first colonizers and explorers. During the transitional late colonial and early Independence periods Latin America sees a significant change in the discourse of powers, and Hispanic Orientalism reflects this oscillation between the past and the present therough the works of the Latin American authors from the seventeenth to the nineteenth centuries. Finally, once the non-imperial discourse of power established itself in the former Colony, a new modern stage in the development of Hispanic Orientalist paradigm takes place. It is marked by the desire to differentiate itself from the $\mathrm{O}(\mathrm{o})$ thers, as manifested in the works of the representatives of Modernism and the Boom. 


\section{TABLE OF CONTENTS}

CHAPTER

PAGE

INTRODUCTION 1

CHAPTER 1. The Reinvention: The Establishment of the Hispanic Orientalist

Paradigm in Reconquest and Post-Reconquest Iberia ...................................... 18

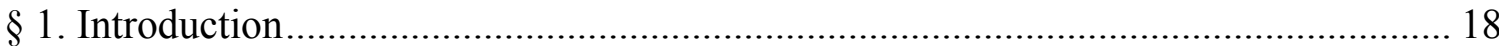

$\S 2$. The Reconquest: The Invisible or Overlooked Other ......................................... 28

$\S 3$. The Renaissance: The Sentimental Moor Caught in the Shift of Power ................... 42

$\S 4$. The Spanish Kingdom: A Search for Unity and the Europeanization of the Other 51

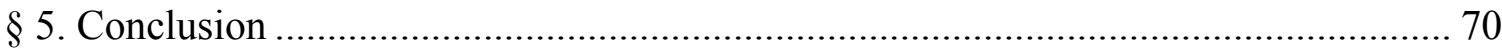

CHAPTER 2. The Appropriation: The Early Colonial Migration of Hispanic

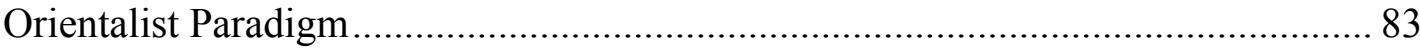

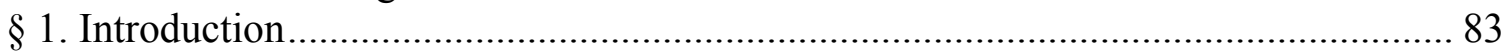

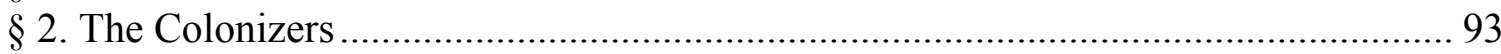

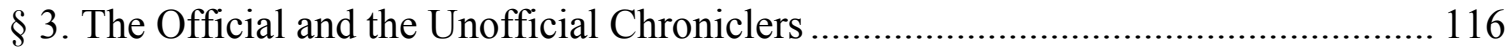

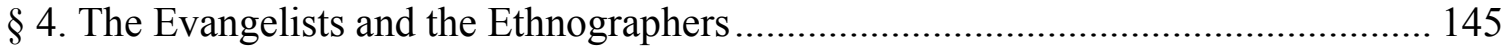

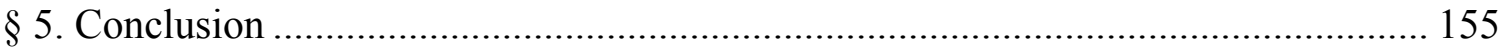

CHAPTER 3. The Transition: Hispanic Orientalism before and after Latin American

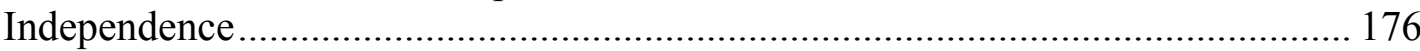

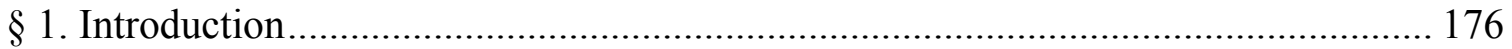

$\S 2$. Orientalization through Self-Reinterpretation in the Late Colonial Period: "Mundo iluminado" by Sor Juana Inés de La Cruz........................................... 183

$\S 3$. Orientalization through Segregation in the Castas Paintings of the Eighteenth

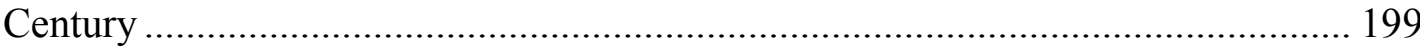

$\S 4$. Differentiation through Reinterpretation: The Gaucho and the Oriental in

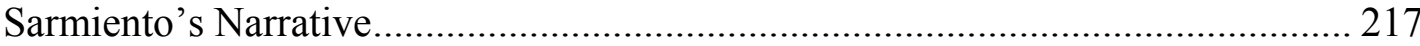

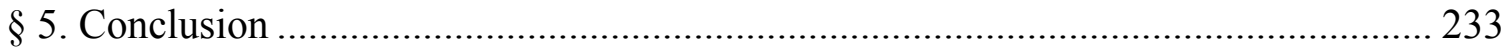

CHAPTER 4. The Differentiation: Hispanic Orientalism in Modern Latin America .... 251

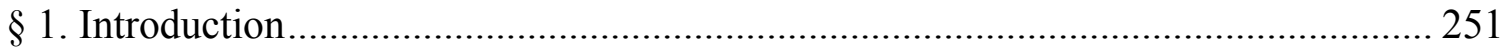

$\S 2$. Differentiation through Reinterpretation: The Traditional and the

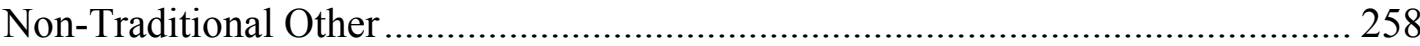

$\S 3$. The Search for Latin American Identity in the Oriental Mirror: The Forking Orientalism of Jorge Luis Borges................................................................... 282

$\S 4$. Differentiation through Self-Orientalization: Revalorization of the Traditional

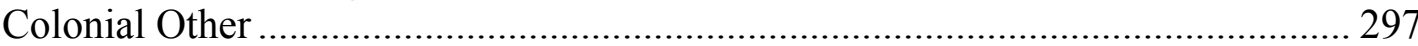

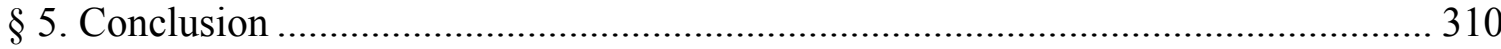

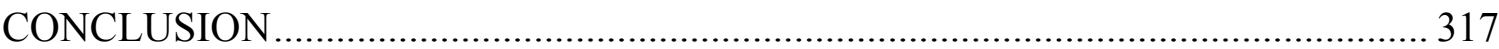




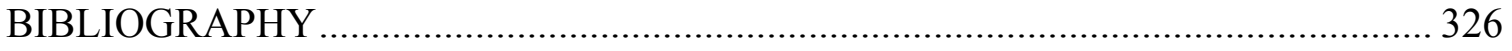

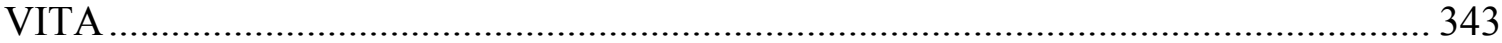




\section{INTRODUCTION}

Political and economic challenges since the early twentieth century, rooted in the cultural and ideological clash of Western and Eastern civilizations throughout the Modern World, resulted in the popularization of Orientalist studies. The much debated topic of Orientalism originated in Edward Said's seminal work Orientalism (1978), but started to evolve and diversify, depending on the area to which it was applied. Nevertheless, it would be wrong to claim that the study of Orientalism began with Said, as historical circumstances play an important role in the development of the Orientalist relationships. For instance, already Aristotle in his work The Politics tried to lay a scientific ground for an opposition between the East and the West. Referring to Orientals, he declared that "the peoples of Asia, by contrast [with the Nordic European races], are warm: therefore they were intelligent and skillful. Unfortunately, the heat also sapped their strength" (1327).

Later in history, the Aristotelian opposition was not forgotten. The posterior descriptions of Asians are often built either to contradict or to reassure this model. Beginning with the Roman Empire and up to sixteenth-seventeenth centuries, Asians are portrayed as experts of war, whose skills are often equal to the ones of their counterparts. This comparison arises from the constant battle encounters of the East and the West in the Iberian Peninsula, the Crusades and the Eastern hegemony in the Mediterranean Sea, the rise and fall of the Eastern Roman Empire, the Byzantium, and Constantinople under the Ottoman siege (1453). As David Blanks and Michael Frassetto state, "these varied perceptions remind us not just that the East has always held a certain fascination for 
westerners; more importantly, the European view of the "other," like the European view of the "self," has since classical times revolved around an ever-changing set of historical circumstances" $(1,3)$.

As can be seen, the awareness of the existence of such an opposition as East-West existed long before the first Orientalist studies appeared. At the beginning, the perception of the foreign Other was constructed from subjective conclusions, but the more contact the Europeans had with the Oriental world, the more prominent were the differences between "us" and "them," the self and its antagonist. The Other, therefore, began to serve as a mirror, from which European civilization shaped itself. ${ }^{1}$ However, this mirror has an interesting new dimension. As Rana Kabbani states, "it is a common place of Orientalism that the West knows more about the East than the East knows about itself; this implies a predetermined discourse" (10). As a result, the West claims the absolute knowledge of the essence of the East, which compromises it as an objective observer and, therefore, raises the question of the legitimacy of the Western observation of the East.

María Rosa Menocal notes that the West converted the writing of history into a myth-making process, pretending to forget "that history is written by the victors and serves to ratify and glorify their ascendancy" (1). In her analysis of the raisons d'être of Orientalism, Silvia Nagy-Zekmi focuses on its role in the establishment of the identity of the colonizer, a crucial process in the history of both Spain and Latin America. She suggests that Orientalism “no sólo 'produce' (discursivamente) el Oriente (conquistador y oprimido), sino también el Occidente 'imperial', promoviendo discursos de autoconocimiento, porque cada cultura requiere un 'alter-ego' diferente, ya que esta misma diferencia sirve de base para la autodefinición" ("“produces' (in discourse) not only the 
Orient (conquered and opressed), but also the 'Imperial' Occident, promoting the discourse of self-knowledge, because every culture requires a different 'alter ego,' and this very same difference serves as a basis for self-definition"; 13). Thus, Orientalism in the Hispanic World becomes a defensive mechanism that allows European to address the threat of the Other, as well as identify the self to create a favorable version of history.

Said's Orientalism theorized the modern process of interaction between colonial and colonized societies. Nevertheless, it is important to remember that Said's analysis follows from the nineteenth-century British and French colonial policy in India and the Middle East. Therefore, its direct application to the Hispanic world is problematic, which he himself points out in the Spanish edition of his book. While Said's followers praised his intent to define the intricate relationship between the East and the West, his critics pointed out the limitations of his theory. Some of them claimed the existence of different versions of Orientalisms, which varied in space and time according to the specific cultural environment and political background, Said's Orientalism being one of these variants.

Such was the fate of Hispanic Orientalism. There were several attempts to characterize and include this phenomenon within Said's original paradigm of Orientalism as a hegemonic discourse of domination. Appraisal of Hispanic Orientalism has been polarized by the desire to either validate or refute Said. The predominant tendency follows the idealized perspective of Hispanic Orientalism proposed by Julia Kushigian, who argued for a marked veneration of the Orient in Spanish and Latin American literature (Orientalism in the Hispanic Literary Tradition, 1991). However, she focused on the twentieth-century Orientalist practices in Latin America where the dominant non- 
imperial discourse of powers marked the evolution of the notion of the self and the Other. As a result of these studies, the complexity of Hispanic cultural encounters with the Other has been simplified and the dynamics of Orientalism in Hispanic literature remain illdefined.

Cultural interaction played a crucial role in the history of the Spanish speaking world, as early as the Medieval Reconquest of Spain and the Conquest of America during the Renaissance. Such contacts, first between Spaniards and Moors, then between Spaniards and Amerindians, were copiously reflected in literature. They scrupulously depicted the complex nature of the relationship with the unknown Other and the reactions of the dominant culture to it. Today, these encounters are labeled Orientalist. The present research proposes a new dynamic model for Hispanic Orientalism. It addresses a more nuanced and complex nature of Orientalist relationships across space and time. Unlike previous studies, it is derived from the analysis of the development of the original Medieval Spanish-Arabic paradigm and its reflection in the New World and transition onto modernity. Therefore, it takes into consideration the most important encounters with the Other: Medieval Moorish and Jewish, Amerindian and the later encounters of postIndependence Latin America with Europe and the traditional Orient. This bidimensional approach takes into consideration the changes in Hispanic Orientalism across both space and time. The proposed dynamic paradigm can explain the numerous peculiarities of Latin American depictions of Orientalist encounters in later centuries, while at the same time serving as a new tool for researchers and readers.

The primary purpose of the present study is to establish the original paradigm of Hispanic Orientalism and trace its development from its inception and onto Latin 
American modernity. It analyzes the phenomenon during four distinct time periods marked by significant social and historical changes: in key works of Medieval and Renaissance Spanish literature depicting the Semitic Other; then during its migration to the New World and the encounter with the new Amerindian Other; the transitional period of late Colony and early post-Independence when the roles of the self and the Other underwent a significant revision; and, finally, its development onto a period of modernity that embarks on the revisionist process of the colonial Orientalized past. Unlike previous studies, it takes into consideration both positive and negative aspects of the changing nature of Hispanic Orientalism, as well as the continuity of Orientalist tradition as the original paradigm is tested across space and time. The resulting dynamic paradigm contributes to the analysis of a wide range of texts depicting "Otherness" in Latin American symbolic production throughout its history.

Such a wide geographical and temporal span requires a solid literary corpus to be analyzed in order to establish and trace the changes in Hispanic Orientalism. The preference of literary works over other sources is defined by the fact that "writers have a marvelous tool at their disposal, imagination, which allows them to make believe. They can attribute to fictional characters things they themselves feel and think" (Memmi Decolonization 36). In other words, literary works have a wider audience and, as a result, a more powerful impact on popular imagery. At the same time, their influence is subtle and often the the public is not aware of its depth. Such stereotypes and connotations become more persistent in the popular imagery, since they are not regarded as imposed on oneself. However, the present research also refers to other non-literary types of representation of the Other, like eighteenth-century castas paintings. The main criterion 
for the inclusion of such production is its significant and wide-spread impact both in the Colony and the metropolis.

In order to establish the original paradigm of Hispanic Orientalism it is essential to refer to Medieval Spanish history. It was a period when the formation of the Spanish nation as a single cultural entity took place. Parallel to this process was the almost eightcentury Moorish presence in the Iberian Peninsula (711-1492). ${ }^{2}$ Thus, the Arab world became the first significant foreign Other, against which the nascent Spanish society was tested. It is during this period that the Spaniards defined their identity and distanced themselves from the invaders. The aftermath of this first massive clash is the creation of the stereotypical images of the European self and the Oriental Other. Rana Kabbani notes that the two dominant themes in the European narration of the East are "the first ... the insistent claim that the East was a place of lascivious sensuality, and the second that it was a realm characterized by inherent violence" (6). Similarly, the original paradigm of Hispanic Orientalism was an unstable structure that relied heavily on the hegemonic discourse of power. As the latter changed, so did Hispanic Orientalism.

Edward Said was one of the first to study the influence of the discourse of power on the relationship with the Other. ${ }^{3}$ He analyzed Orientalism from the point of view of an evolving discourse, taken from the correlation of various simultaneous realities. In the Hispanic world, the first such change occurred towards the end of the Reconquest. As the Christians advanced in their liberation process, Moorish influence, both cultural and political, was diminishing. As a consequence, there was a shift in the role of the dominant and the subaltern cultures. At the beginning of the Reconquest, Spanish society was dominated by the Arabic invader, while later it was the Moors who became the subaltern. 
The shift is copiously reflected in the literature of the period, where the image of the Moor changed from a menacing threat to a romantic hero, almost equal to the Christian hero.

Peninsular Hispanic Orientalism plays a crucial role in the ultramarine campaign of the metropolis. Hernán Taboada points out that the new type of relationship formed between the Spaniards and the Moors served as a future reference to all the encounters with the Other. He insists on historical and cultural links between the Reconquest and the discovery of America and its further conquest. Taboada observes this process as a continuation of the Christian Crusades in search of an expansion of Catholicism and the European hegemony in the West (45). The first travel logs and chronicles of the period reveal the eradicable link between the Reconquest and the Conquest in the mentality of the people during that time. In this light, the analysis of the transatlantic migration of Hispanic Orientalism is crucial. In the Colony, the subaltern Other, the Amerindians, were compared and contrasted with the traditional Other. However, while the conquest of the New World was perceived as a continuation of the Reconquest and the Crusades, the relocation of the paradigm, the new geopolitical situation in Spain and in the Colony, and the dominance of the imperial discourse of powers caused several changes in the original paradigm of Hispanic Orientalism.

The fact that Hispanic Orientalism is not static, but rather changing in nature, raises the first question of the present research: how does the paradigm of Hispanic Orientalism change across time and space? And if it does change, which factors have the most considerable impact on this unfolding process? As the research showed it is the historical progress and the relocation from Spain to Latin America that had the most 
significant impact on Hispanic Orientalism. In this process of development, the mimicry of the discourse of power, implied in Said's concept, plays a crucial role. ${ }^{4}$ It is the inner impetus of the adjustment of the relationship between the hegemonic and subaltern cultures that defines the dynamic nature of Hispanic Orientalism. However, this particular quality is commonly overlooked in Orientalist studies of both Peninsular and Latin American literature. According to Said, a fundamental role in the formation of the Orientalist mimicry is education, which is "threatened by nationalist and religious orthodoxies" (xxvi). His work addresses modern history; however, these words can be equally applied to Inquisition dominated Medieval Spain or the racially segregated Latin America of the sixteenth-nineteenth centuries.

The criticism of the Hispanic Orientalist approach during the Colonial period is a recurrent topic for the researchers in the field. As such, Julia Kushigian, despite her explicit opposition to Said's view, also claims the semi-mythical nature of Hispanic Orientalism, whose "categories are our own, it is as we want it to be" (Orientalism 23). Therefore, she admits to doubt the sincerity of the praise of the Other by the representatives of the hegemonic culture in the early colonial literature. On the other hand, in her study, Kushigian discloses the heteroglot nature of Orientalism in Latin America, as a result of the close coexistence of the two diverse cultures both in Medieval Spain and in conquered Latin America (Orientalism 53). The geographic proximity of Arabic-Andalusian and Castilian cultures resulted in mutual literary influence that can be found in popular lyric poetry (Sánchez-Albornoz 63). The same factor, the historical clash of Europe and the Ottoman Empire, led to the contamination of the chronicles of the conquest of the New World by elements pertaining to the Islamic culture (Taboada 
32-33). Hispanic Orientalism indeed is more heteroglot than the Anglo-French version. The reason behind this arises from the role that the East played in the process of interaction with the West. In the Hispanic world it is the conqueror that is gradually reduced to the position of the conquered. As a consequence of the shift, the relationship between the hegemonic and the subaltern cultures appears to be more complex and multifaceted that in the cases of the European domination in the Middle East.

Once established in the New World, the paradigm of Hispanic Orientalism did not remain static. In the late Colonial and early post-Independence periods it was the nineteenth-century political and the economic crises in the metropolis and the desire for self-assurance of the emerging nations that propelled the changes. The former Colony, once independent, tried to shake off its inferiority complex, imposed, on one hand, by the Orientalist prejudice of the colonizer, and on the other, by the underdeveloped economic and political processes, as well as the constant desire to Europeanize the Latin American self. The traditional "discourse of empire," suggested by Said, is dismissed and is gradually substituted by a non-imperial discourse by 1898 when Spain loses its most valuable colonies at the moment, Cuba, Puerto Rico, and the Philippines. The change in discourse indicates that not all the relationships between dominant and dominated cultures followed Said's approach. ${ }^{5}$

However, the transition between the two periods and discourses did not happen immediately after (or before) the independence of the Colony. Already during its later years, there is a noticeable desire of differentiation on the part of the authors of the period systematically suppressed by the metropolis. Hence, the end of the Colonial period and the early Independence constitute a type of buffer zone between the major changes in the 
approach to the Other for Hispanic Orientalism. Once the nascent Latin American nations are established, and the non-imperial discourse becomes dominant, the modern era of Hispanic Orientalism begins. It is important to note that, unlike the discourse of empire, the non-imperial discourse depends on juxtaposition, and not on hierarchy; it is an interaction of adjacent powers, each of them trying to exercise influence on each other culturally, politically, or economically. The relationship between the rival cultures in this case is not as hierarchical as in the first case. Consequently, it lessens the possibility of direct impact on the Other. The vector of this relationship is also different. It indicates interaction rather than more passive action and reaction, creating a greater resistance and, as a result, diminishes the mutual influence. These characteristics lead to a more superficial reciprocal influence between the two rival cultures. In the Hispanic world, such was the situation in post-imperial Spain and Latin America, which leads to the next research question of this study: how different is Hispanic Orientalism from the imperial and non-imperial discourse?

According to the premises above, our hypothesis is that the model of Hispanic Orientalism, sensitive to the sociopolitical changes in society, undergoes a significant alteration closely related to the shift in dominant discourse. The premises for this supposition can be found in the general studies of Hispanic Orientalism. Unlike Said's negative view of the Orientalist imperial encounters, Julia Kushigian creates a positive image of Hispanic Orientalism in post-Colonial Latin America. Kushigian analyses this phenomenon in the twentieth-century works of Jorge Luis Borges, Octavio Paz, and Severo Sarduy. Her thesis examines the veneration of the Orient in the New World, therefore, she determines as eradicable the distinction between the positive Hispanic 
perception of the East and the Anglo-French concept of Orientalism described by Said. She alleges that "whereas in France and in England the Orient was never allowed to permeate European culture successfully, it has been a viable presence and cultural source in the Hispanic world since the Muslim invasion . . . and it remains so" (Orientalism 101). It is this mutual influence between the Orient and the local culture that allows her to refute Said's negativity. Nevertheless, both Said and Kushigian agree that the historical circumstances find their reflection in the dominant discourse, as well as Orientalist practices of the hegemonic society.

In her analysis of the modern period in Hispanic Orientalist relationships characterized by the non-imperial discourse of power, Julia Kushigian adopts a positive approach, claiming that "Hispanic Orientalism opens the space to an infinite blending of the oppositions" (Orientalism 3). According to her, the blending never occurs in traditional Orientalism. However, the case of Hispanic Orientalism is different: it allows for "the interanimation of oriental images" and "provides a renovating link that promotes an open dialogue between Spain and Hispanic America" (Orientalism 6). Kushigian insists that the Hispanic World offers the juxtapositional and non-hierarchical structure of the relationship with the Other. Therefore, a distinctive aspect of Hispanic Orientalism is its openendedness and polyglot nature. It maintains a constant dialogue with the Other that depends on the veneration of the Other's self (14). According to Kushigian, unlike Said's Orientalism, Hispanic Orientalism lacks imperial aspiration, which is what makes it able to comprehend and appreciate its Other:

Hispanic Orientalism distinguishes itself in a momentary blending of opposites and interanimation of images grounded in a respect for diversity. 
This Orientalism reflects not so much a political posture towards the Orient ... but is, rather, a more thoughtful approach that values the dialogue of a discourses, reflecting an antithetical denial of and openness to the Other ... providing an enriching discourse that does not seek to exercise social or political control over the Orient. (Orientalism 10-11)

Nevertheless, it is true only for the non-imperial discourse. The imperial discourse has a different approach to the nature of relationship of the dominant power with the Other. It is why the dynamic nature of the paradigm of Hispanic Orientalism proposed in the present study constitutes a new approach to this question. The specific characteristics of the paradigm at each stage can be determined by the analysis of its static representation during the determined periods. The clear division of Spanish history into imperial and post-imperial periods is crucial for the analysis of Hispanic Orientalism, since the latter is characterized by coexistence of the dominant and subaltern culture, while the former has a hierarchical structure.

In summation, the present study addresses the dynamic nature of Hispanic Orientalism across space and time. The paradigm established in the course of the research is tested against literary and art works that represent four main periods: the Conquest and the Reconquest of Spain, the early Colonial period in Latin America, the late Colonial and early post-Independence, and twentieth-century Latin America. The temporal division allows reviewing in detail the existing differences between the imperial and nonimperial discourse in Hispanic Orientalism, as well as defining the characteristics of each of them. It provides an answer to the question about the role of Hispanic Orientalism and its differentiation from the traditional Saidian Orientalism. There are four phases of 
textual analysis in the present research. First, the original paradigm for Orientalism is established on the basis of the study of Spanish Medieval and Renaissance literary production. The works selected will target the period of the Reconquest of Spain, since this is the time when Castilian culture experiences one of the first and most challenging encounters with the Other. The analysis of this period is derived from the study of Cantar de mio Cid (1140), El Abencerraje y la hermosa Jarifa (1565), and Guerras civiles de Granada $(1595,1604)$.

Second, the implementation of the original paradigm in the New World is reviewed in the first chronicles and travel logs depicting the ultramarine campaign. Three major groups of authors who projected their vision of the Other during the early Colonial period are addressed here: the first colonizers and explorers, Christopher Columbus and Hernán Cortés; official and unofficial chroniclers, like Bernal Díaz de Castillo and Francisco López de Gómara; and, finally, religious men, like Fray Toribio Benavente (Motolinía). The broad literary corpus contributes to the validation of the paradigm obtained.

Third, after the revised Hispanic Orientalism has established itself in the Colony, towards the late Colonial years it enters a brief period of stagnation that we refer to as transitional period. It coincides with the independentista movement and marks the shift in the discourse of power. This is the period when the most significant change of in Hispanic Orientalism is germinated; however, it is marked by the oscillation of the authors between the traditionalist Orientalism and the newer approach to the Other. The works analyzed in this section are selected poetry by Sor Juana Inés de la Cruz, the socalled castas paintings, the pictorial depictions of conservative Orientalism, and one of 
the fundamental Latin American novels, Facundo: civilización y barbarie, by Domingo Faustino Sarmiento.

Finally, the modern period of Hispanic Orientalism begins at the end of the nineteenth and the beginning of the twentieth centuries, when the independent Latin American nations start entering the world political arena, and the former colonized was eager to revise its historical past in order to validate its present. In the process, it reviewed its approach to the traditional Orient, as in the modernista essays by Enrique Gómez Carrillo and Jorge Luis Borges in order to define the self, but most importantly, it revalidated the Orientalized past, giving voice to the former Other, the Amerindian, as in Elena Garro's short stories. Her revision of the image of La Malinche is of special interest, as its perception by the authors throughout the history is indicative of their position in regards to the Orientalized image of Latin America.

The criterion for the selection of literary works was their impact on society and their representation of the Other from the hegemonic point of view. The latter was selected to ensure the consistency of the Orientalist paradigm. At the moment of their creation most of them acted as a source of perpetuation of the history of the conquerors, paraphrasing Miguel León Portilla's words. However, each period contains literary works depicting the nuances in the relationship with the Other. The Orientalist "vision of the vanquished" represents a different point of view, not less valuable; however, it is not analyzed in the present research.

Since we regard Hispanic Orientalist paradigm as dynamic, under the term Orientalism here we understand multiple forms of interaction with the Oriental Other rather than a static orthodox Orientalism. In her contraposition of the terms Orientalism 
and orientalism(s), Christina Civantos points out that Orientalism (with the capital letter) still "signals that "the Orient" refers to a construct ... Ultimately "the Orient" is a geographic location, but one of unclear, and Eurocentric definition" (viii). Therefore, for our analysis, the term with the capital latter is used. However, it still comprises the idea of a multifaceted and changing nature of Hispanic Orientalism.

Finally, it is necessary to admit certain limitations imposed to the research by its goals. Those are unavoidable because of the ambitious geographical and temporal span of the works analyzed. The purpose of this study is to propose a framework, which can be further developed and enriched by the analysis of the Hispanic Orientalist encounters of different nature or from a different perspective (the view of the subaltern, for example). The literary and art works analyzed provide a generic paradigm described during each of its four major stages. Yet each of them can be further elaborated and reviewed for a particular author or cultural Other.

\section{NOTES}

\footnotetext{
${ }^{1}$ David Blanks and Michael Frassetto refer to this process of initial differentiation between "us" and "them" as defining of the self-image of the Europeans. The numerous encounters of the East and West, as they indicate:

... created an image of the Saracen, Moor, or Turk that was wholly alien and wholly evil. In both popular and learned literature Muslims were portrayed as cowardly, duplicitous, lustful, self-indulgent pagans who worshipped idols and trinity of false gods. On the other hand, the creation of such a blatantly false stereotype enables Western Christians to define themselves. Indeed, the Muslim became, in a sense, a photographic negative of the self-perception of an ideal Christian self-image, one that portrayed Europeans as brave, virtuous believers in the one true God and the one true faith. By debasing the image of their rivals, Western Christians were enhancing their own self-images and trying to build self-
} 
confidence in the face of a more powerful and more culturally sophisticated enemy. (3)

Therefore, the Orientalization of the Other played crucial role in the process of formation of Christian states in Europe. It allowed them to draw and to retain a specific picture of the self and the nation in people's imagery, a picture pre-selected to fit Christian values and, hence, reassure Christian dominance in Europe.

${ }^{2}$ The reason why this is the first Orientalist encounter is that it is the first time in history that we can talk about the Spanish nation as a whole. The marriage of the Catholic Monarchs, King Ferdinand II of Aragon (1452-1516) and Queen Isabella I of Castile (1451-1504), and their successors allowed for the apparition of a new unified kingdom instead of the small segregated kingdoms which had existed in the Iberian Peninsula during the first centuries of the Moorish Invasion. The new political force seeking selfidentification used the process of Reconquest of the Peninsula from the foreign invader to test itself, since the process of self recognition can be successful only when there is a counterforce. Hence, the Orientalist relationship in Medieval Spain not only served as a basis for the future interactions with the Other, but also contributed to the consolidation of the Spanish nation as a whole.

${ }^{3}$ Therefore, the discourse of power is highly important for the nature of Hispanic Orientalism. Edward Said's theory in this is close to the theory of Miguel de Unamuno, offered in Niebla and called by Philippe Lacoue-Labarthe "the theory of desistence" (Typography: Mimesis, Philosophy, Policy, 1989). It disintegrates the essence of a subject in three hypostasis: the real subject, the ideal subject and the subject as perceived by the Other. Such process of analysis rescues the multifaceted structure of reality. Its multilayered essence is nowadays diminished and simplified by the imperial discourse of power.

${ }^{4}$ In the process of definition of Hispanic Orientalism one cannot disregard the predetermination of the events by past history and its intimate connections to historical and political changes and. It is vital to admit that "the essential aspects of modern Orientalist theory and praxis . . . can be understood, not as sudden access of objective knowledge about the Orient, but as a set of structures inherited from the past, secularized, disposed, and re-formed" (Said 122). As such, a reliable paradigm of Hispanic Orientalism can only be traced in its development. Such approach also reveals the continuity and the rupture in the process of formation of Orientalist-type relationships between the dominant and dominated cultures.

${ }^{5}$ The imperial domination implies a very specific hierarchical structure for the interaction between the center and the periphery. It is based on the process of direct or tacit forcing of the suppressed or conquered Other into the hegemonic self, as it happened in the Roman, Russian and Ottoman Empires. Such was the case of the Spanish 
domination in Latin America and the Spanish Reconquest. In the latter, two different periods can be distinguished: the Moorish dominance in the process of the conquest of Spain and the Christian or Spanish dominance during the later centuries of the Reconquest. 


\section{CHAPTER 1.}

\section{The Reinvention: The Establishment of the Hispanic Orientalist Paradigm in Reconquest and Post-Reconquest Iberia}

\section{§ 1. Introduction}

Orientalist relations as a type of interaction between dominant and dominated cultural selves appeared well before the British and French colonialism described by Edward Said. In the course of its history, the Iberian Peninsula was a natural place of encounter of different civilizations and cultures: Phoenicians, Greeks, Romans, and Visigoths, among others. Cultural layers began to set the ground for the later development of a national character. But it is the Moorish invasion that stands out among these encounters because of its enormous impact on the Peninsula as a whole. Therefore, in order to trace the development of the paradigm of Hispanic Orientalism, it is crucial to examine Spanish Medieval history and analyze the most impacting encounter of the nascent Spanish nation with the Other, that is the Moorish conquest and the ensuing Christian Reconquest of Iberia. The Middle Ages and their religious controversy were at the center of what was known as "the Islamic problem." The development of the stereotype of the Muslim Oriental went through the three stages: rise, zenith and fall between the years 650 and 1570, leaving deep traces on the European mentality (Southern 13). Nevertheless, the impact of the encounter with the Oriental Other in Medieval Iberia has been considerably underestimated, if not neglected, for a long period of time in the accounts of both Peninsular and European history. 
The voluntary or involuntary forgetfulness and the negation of the role of the Orient in European development have influenced scientific minds up to the modern era. María Rosa Menocal gives an example of the century-long search for the etymology of the word trobador, singer of love poetry, an occupation that along with juglar, singer of narrative poetry, defines the literary processes of Medieval Europe. She points out that it was in 1928 that a renowned Spanish Arabist Julián Ribera proposed that trobador originates in the Arabic verb taraba. ${ }^{6}$ Its meaning is very close to the Spanish derivate, which also means "the singing of poetry." Nevertheless, this proposal "was not only not favorably received, but worse, it was not even deemed worthy of . . . discussion" (qtd. in Menocal ix-xii, 78). It seems that the Arabic etymon along with Arabic influence as a whole was purposefully overlooked, as if its recognition would go against the image of the Oriental Other fabricated in Europe at the time, as well the European self-image based on a myth of cultural and racial purity Nevertheless, there is abundant linguistic evidence of Arabic influence in almost every aspect of Medieval Iberia: from the numerous traces of Arabic in Castilian and other Iberian languages, the toponymy of the Peninsula, political and military institutions, its arts and sciences, to such things as flora and fauna. It is the Orient that introduced in Europe a great number of objects that became attributes of luxurious life: animals and insects like the peacocks, the Angora cat and goat, the silkworm; flowers and plants like tulips, daffodils, Persian lilac, jasmine, dates, pistachios, cider, and coffee among others (González Palencia 11-12).

Another aspect of the Medieval clash of Iberia with the oriental Other, usually overlooked in the process, is the so-called "Visigoth myth." The Visigoth kingship at the time of their presence in the Peninsula was not hereditary. When Rodrigo was elected to 
lead the Visigoths, the supporters of his rival essentially hired a mercenary force to strike against him. The Moors, thus, invited to engage in the hereditary was in the Peninsula, soon took control of the region. Some argue, however, that the Visigoths retreating to the North and starting the Reconquest from there, is a historical myths, as the Asturias needed to establish its right to the territory, and claimed their Visigoth origins in order to do so.

The common tendency in depicting the Oriental Other in European narratives of this period was, as Kabbani suggests, "a deliberate stress on those qualities that made the East different from the West, exiled into an irretrievable state of 'otherness"' (5-6). The interaction between the Christian East and the Muslim West begins with nascent Islam. Norman Daniel traces an interesting parallel between the development and expansion of Islamic thought and the Christian outreach to the North (the conversion of England). $\mathrm{He}$ states that "the two processes are in no way comparable in their importance to the history of the world" (The Arabs 10). It is true that the West was, in a way, fascinated by the East, as if unwillingly accepting the fact that "Europe was also the product of internal colonization and cultural assimilation" (Blanks, and Frassetto 2). Therefore, the encounter of the two selves, European Christendom and the Muslim Other, shaped the image of the East in the West and vice versa.

The Crusades played an important role in defining the nature of this interaction. In a sense, the Crusades were for Christians as jihād was for the Muslims, both physically and spiritually (Daniel, Islam 125). The conversion of the Saracens or any Orientals, in general, was never set as a goal for the first Crusaders: in 1095, during the First Crusade, it is not even mentioned; in 1147, during the Second Crusade, conversion is alluded to as 
a merely hypothetical possibility. However, the interest grows exponentially, and by the time of the Fifth Crusade (1217-1221), conversion becomes a primary goal on the very battlefield (Kedar 58-60, 71-72). Gradually, the Crusades revealed the abysmal difference between the goal of the campaign and its reality. The purpose of the crusaders was to free the Christian Orient and the Christians in those lands invaded by the enemies of the Church, but the encounter with the Greek, Coptic, and Syriac co-religionists resulted in xenophobia (Daniel, The Arabs 114, 261). For instance, the policies of Pope Innocent III included discriminatory legislation both for the Moors and the Jews. Among the orders they had to comply with was to wear distinctive clothing in order not to be mistaken with Christians. But even Oriental and Greek Orthodox Christians were treated differently from European Christians (Tolan 196-97). Europe felt surrounded and threatened by the Other: the Muslim Other and the (Oriental) Christian Other at the same time. The spirit of the Crusades remained alive long after the end of the Holy War, and even continued into the modern era. It is not surprising then that on July 22, 1920, when the French army entered Damascus, the head of the army, General Gouraud, proceeded to the tomb of the legendary defeater of the Christians during the Third Crusade, Yusuf ben Ayub (Saladin), who reconquered Jerusalem in 1187 , where he triumphantly proclaimed: "Nous revoilà, Saladin!” (“We are back, Saladin!”; Kabbani 5).

The tendencies in the relationship with the Other had economic repercussions as well. Benjamin Kedar notes that while the policy of conversion was being popularized by papal bulls and the Order of Santiago, economic interests presented a militant opposition to conversion. When a Muslim slave became Christian, his "economic impact" was lost in this transformation, as he could no longer be treated as a non-Christian. There were 
numerous reported cases of masters trying to prevent the conversion of their slaves merely for economic reason. Some of the Christian and Jewish slave owners in Barcelona even demanded that the Church compensate them for their losses caused by the baptism of their slaves (Kedar 48). The controversy surrounding the problem of conversion affected, therefore, not only the culture and the politics, but also the economics of the kingdom.

In the Iberian Peninsula, the encounter with the Oriental Other was overwhelmingly sudden, as the territory was very rapidly annexed to the great Caliphate of Damascus as a result of the military campaigns of Tariq ibn Ziyad (689-720) in 711 and Muza (640-716) in 712-14. The celerity of the invasion could be attributed not only to the high level of development of the Muslim kingdom, but was also caused by the decline of the weakening Visigothic rule in the Peninsula. Already by 756, the independent Emirate of Cordoba was established by 'Abd al-Rahman I (731-788) with the ruling Umayyad family. In its process of development, the peninsular Islamic state evolved from an Emirate to the Caliphate of Cordoba in 929, during the rule of 'Abd alRahman III (891-961), and later underwent a process of disintegration into taifa kingdoms (from the Arabic ța ${ }^{`} i f a$, "sect"), as a result of the policies of Almanzor I (9381002) (Tuñón de Lara 74-79). Sánchez Albornoz points out that especially during the Emirate period there was a significant influx of Arabs to the Peninsula both from Africa and the Levant, especially from Syrian territories, as Damascus played a crucial role in the development of the Muslim Empire (42-44). Most of the immigrants were soldiers, relocated to Iberia, who later settled down in Al-Andaluz. 
The reaction to the Muslim invasion, the process called by Christians "the Reconquest," started almost immediately after the beginning of Muslim rule. Its symbolic launch is the victory in the battle of Covadonga in the north of the Peninsula in 718. But it is during the period of the disintegration of the Caliphate in the eleventh century that the Christian kingdoms became the dominant military power in the Peninsula. With the shift of power, the reinvention of the image of the Moor received a new impulse. It is also important to take into account the cultural and ethnic diversity of the Peninsula during the Reconquest. This diversity defined the intricate character of the relationship between Christians and Moors. The seven-century long Reconquest provided enough time for the gradual interpenetration of local and Moorish cultures, which resulted in the establishment of an Orientalist relational paradigm unique to Iberia. Nevertheless, to understand Hispanic Orientalism, it is important to accept the fact that the process of Reconquest did not stop after 1492, as the military reconquest was followed by thea cultural and symbolic reconquest as well. Both the military and cultural conquests had long repercussions throughout the centuries, which resulted in the persistence of the original paradigm of the relationship with the Oriental Other in Iberia, and later, in Latin America.

There were numerous sociocultural and ethnic groups ${ }^{7}$ during the Reconquest; their importance and prestige in Spanish and Moorish societies changed, as the shift of power occurred. During the first part of the Reconquest of Iberia, the most distinguishable group of people who were the product of the cultural and religious encounter of Christian and Muslim societies were the Mozarabs, Christians who lived under Muslim rule but preserved their original religion. Despite being Christian, the 
Mozarabs adopted some of the cultural habits of the Arabs, and hence their hybrid name. The original Arabic name for another group, the Muladi (muladies), denotes a higher degree of cultural mixture. The successful pace of the Reconquest led to the formation of another sociocultural group, opposite to the Mozarabs, the Mudehars (mudéjares). Its Arabic meaning is "domesticated," referring to the Muslims who continued living in reconquered territory, adopting some of the cultural habits of Christian society.

The general objective after the victory over the Kingdom of Granada (1492) was the creation of a homogeneous Kingdom of Spain. Therefore, the remaining Muslims were under a constant pressure to convert, which lead to their forced conversion into Christianity and the expulsion of those who refused (1609-1610). Those, who formally embraced Catholicism, were denominated Moriscos, a term of Spanish origin, indicating the Islamic heritage of a person belonging to this group. A considerable number of them secretly practiced Islam. There was another sociocultural group, which like the Moriscos appeared as a result of the homogenizing policy of the Catholic Monarchs Ferdinand and Isabella: the Marranos, Jews who had converted to Christianity but practiced their religion clandestinely. The last of the larger sociocultural groups were the Sephardic Jews (sefardies), a group that defined their motherland as Sepharad, or the Iberian Peninsula. They followed Judaism and refused to convert, which resulted in their forced exile in $1492 .^{8}$

The diverse palette of interacting cultural groups created complex social dynamics in the Peninsula, including long periods of peaceful coexistence. To begin with, during the conquest of Iberia by Moors, Christians, though encouraged to convert to Islam, were not forced to do so. Those who continued to practice Christianity were considered 
dhimmi (ذَّي), a non-Muslim "protected subject" who resided in the Islamic territories ruled by shar'ia law. Dhimmi had full religious freedom as they were ahl al-kitāb, meaning that their religion was mentioned in the Qur'an. They had the right to organize their life and community as required by their religious obligations (Mohammed 32-33). Dhimmi were guaranteed freedom of religion, and their lives and possessions were protected by the Islamic government, whose sovereignty they ought to recognize. NonMuslims could not participate in the military, but were protected by the Muslim army. This military protection was paid off by the poll tax, jizya (جزية), which was also used for the improvement of the community (Armstrong 200-1).

The general situation changed when the shift of power occurred during the Reconquest. In the Christian Middle Ages, Islam was considered the result of a fusion of several ancient heresies, but the Moors were never fully treated as heretics until the appearance of the baptized Moriscos. It is then that the Inquisition could attack them. While the Christian dhimmi under Moorish rule were protected by the unalterable Qur'an, Christian law was not as explicit. The fate of Jews is often compared to that of the Moors, since the law in the Peninsula treated them almost equally to the Moorish subjects. However, in reality, the Jews who settled earlier in the Peninsula were welcome in Europe more often than the Moors (Daniel, The Arabs 254-55).

Compared to the Muslim rulers during the beginning of the Reconquest, Christian kings were less tolerant of the Muslim Other. Nevertheless, history gives us several examples of the relatively peaceful coexistence of different sociocultural groups in the Peninsula under Christian rule. The most prominent of them was the rule of Alfonso VI (1040-1109), known for his support of the Muslim subjects in his kingdom. 
He allowed the refugee princess Zaida of Seville to stay under his protection; more so, after she gave birth to Alfonso's only son Sancho, Zaida converted to Christianity around 1091, becoming one of the most famous converts in Medieval Iberia (Kedar 44). The story of reconciliation between East and West became popular in the Peninsula. The lost Cantar de la mora Zaida narrates the story of this relationship, though "the facts are very much jumbled" and sometimes considerably far from reality (Daniel, The Arabs 88). These alterations generally tend to favor one side, the Christians, while exposing the vulnerability of the other side. As a result, the relationship between the Christian king and the Moorish princess is portrayed in an Orientalist, patronizing fashion. Zaida falls in love with Alfonso in a very courtly manner. She is ready to abandon her religion to follow her true love. Some territories, such as Cuenca, come as a part of her dowry. Therefore, the author conveys the idea of Christian superiority over Moorish values and Islamic religion by playing with the historical facts and personalities.

Among Medieval literary works, there is one that most literary critics consider as one of the most influential sources of Orientalization of the non-Christian Other. It is Disciplina clericalis, a collection of stories translated from Sanskrit, Arabic, and Persian into Latin in the twelfth century by a converted Sephardic Jew, Pedro Alfonso. Some of the most famous stories in Disciplina clericalis include "Barlaam and Josaphat," the Arabic version of the story of Buddha, "Sendebar," "Kalila and Dimna," and many others. They were translated into several languages and were referenced by more than 60 European authors during the Medieval and Renaissance periods (González Palencia 3537). Its influence extended into modernity. The work of the School of Translators of Toledo under the rule of Alfonso X the Wise (1221-1284) is another example of the 
respectful relationship with the Other. It not only rescued various Greek, Arabic, and other manuscripts from oblivion, but had among the translators not only Spaniards, but also Sephardic Jews and Arabs..$^{10}$

As a consequence of such historical and cultural changes, the nature of the relationship between the Iberian Christendom and the foreign Other was far from simple. The dominant sociocultural groups were responsible for shaping the image of the Other, which resulted in its reinvention or Orientalization. The complexity of this process is determined by the considerable duration of the coexistence of the two opposing religious groups in the Peninsula, as well as by the constant shifts of power along their already porous frontier. Religion was by far the major factor for the differentiation between the Iberian "us" and the Muslim Other. The Reconquest of the Peninsula went hand in hand with the Crusades, both campaigns carrying a special religious significance. It is not surprising, then, that the public perceived a parallelism between both processes, especially after the conquest of Jerusalem by the Arabs in 1072, and Toledo by the Christians in 1085 (González López 18). Cultural and religious ignorance, along with the desire to create a self-assuring myth, led to the Orientalization of the Eastern Other by the West. This process developed throughout the Middle Ages and into modernity, and became part of the European heritage, passed on with the other values of Western civilization.

In order to establish the concrete characteristics of the original paradigm of Orientalist relationships in Iberia, three historical periods issuing from the initial encounter, and their representative literary works, are analyzed below. These are: the Reconquest (711-1492) and the Cantar de mio Cid (1140); the period immediately after 
the Reconquest until the mid-sixteenth century, exemplified by El Abencerraje y la hermosa Jarifa (1565); and the late sixteenth century and early seventeenth century, which coincides with the publication of the two parts of Guerras civiles de Granada $(1595,1604)$.

\section{§ 2. The Reconquest: The Invisible or Overlooked Other}

The Reconquest was not a homogeneous process. At the beginning, the Peninsula was not culturally or linguistically defined: different ethnic, religious and cultural groups coexisted, while the Castilian dialect gained dominance only between 1067 and 1140 (González López 27). During the first two centuries of the Conquest, Moorish power dominated over the Christian kingdoms. After the tenth century, the active process of the Reconquest and the progressive unifying impetus shifted the balance of power, giving the Christian kings the upper hand, with the exception of some enclave kingdoms, such as the Kingdom of Granada, which would remain a Muslim stronghold until the end of the Reconquest.

An analysis of the representations of the Oriental Other in the documents of the period casts light on the nature of Orientalist relationships during the Reconquest. As religion was a fundamental factor during this period, the documents reflect the juxtaposition between Islam and Christianity. For instance, in the 1140s, an anonymous Mozarabic Christian priest, responding to the need for reassuring his community about the predominance of the Christian religion, wrote a tract with abundant citations from the Qur'an, the Torah, and the Bible. His main goal was to prove that Christianity was the 
only true religion, as "the Jews affirm that they crucified Him, whereas you [Muslims] deny this on your side. But for us the denial of the crucifixion is unbelief, so everyone who denies it is an unbeliever" (Mozarabic Refutation 145). This and many other similar documents launched the process of Orientalization of the Other by reshaping it according to the ideals and needs of the dominant Christian culture.

The juridical documents dating from the twelfth to the fourteenth centuries are an interesting source of information about the complexity of social relationships with the Other. Mark Meyerson notes in his analysis of one of such documents pertaining to the trial of Açen Muça who stabbed Abdalla Centido for killing his half-brother at a Christian celebration:

The murder took place as Christians and Muslims were watching the Corpus Christi procession together. The attendance of members of both faiths at an important Christian religious festival indicates the breaching of religious and social barriers. However, the readiness of Christians to take up arms against Muslims after the murder had been committed points to the fragility of the modus vivendi between Muslims and Christians. (33839)

This and similar documents attest to a crucial fact: despite their cultural and religious differences, the process of mutual influence became a part of their society. Therefore, fertile grounds were created for the growth and development of Orientalist-type relationships between the hegemonic and subaltern cultural groups.

Different written sources depicted these intricate relationships in the Medieval Peninsula. But perhaps the most indicative of the tendencies in Orientalizing the Oriental 
Other is the Cantar de mio Cid (1140). Originated in the oral tradition of the bards (juglares), each of whom reshaped the story to his way of reciting and to the taste of his audience, the Cantar de mio Cid represents the quintessence of the Hispanic Orientalism of the period, which is symbolically represented in the name of the protagonist, Ruy Díaz de Vivar (1043-1099), the Cid (سيد meaning "master" or "lord" in Arabic). The poem narrates the adventures of this Christian hero, his multiple military campaigns, and the capture of Valencia in 1094, which contributed to his reconciliation with Alfonso VI. However, in the background, we can see several Oriental, Arab and Jewish characters, whose interactions with the dominant group, the Christians, cast light upon the process of Orientalization and its ramifications in Medieval Iberia.

These relationships become even more prominent because of the historicity of the poem. Menéndez Pidal indicates that the Christian protagonists are "rigurosamente históricos y fueron coetáneos del Cid" ("strictly historical and were the Cid's contemporaries"; En torno al poema 13). The topography of the poem also lacks invented names and places, in contrast with the French chansons of the period. In a way, the realism of the Cantar tacitly opposes their illusory fantasies, especially those of Chanson de Roland (Menéndez Pidal, En torno al poema 77). The military campaigns and their chronology also describe real historical events. Therefore, the historicity of the poem sets it apart from later works describing the encounter or the coexistence with the Oriental Other in the Peninsula and in Medieval Europe.

Despite all of this, it would be erroneous to affirm that the poem is strictly historical, since it is already contaminated with preconceived constructs of the Other and its place in the Christian world. Analyzing the times when the Cantar was created, 
Southern notes that it was a period of "ignorance of triumphant imagination," as the Europeans knew very little about Islam, which they saw not as a religion, first of all, but as a "large number of enemies threatening Christendom from every direction" (14). Even Menéndez Pidal, analyzing the poem as a whole, cannot but note that the Medieval author “acertó a idealizar ... recuerdos locales, uniéndolos para siempre a la historia poética del héroe y haciéndolos brillar en ella aún más que las hazañas que interesaban a toda España" ("managed to idealize the local memories, linking them forever to the hero's poetic history and making them shine even more than the heroic deeds that interested the whole of Spain"; En torno al poema 20).

The idealization raises a very important question for the analysis of the origins of Hispanic Orientalism: the veracity of the assessment of the Other. While the backdrop is historical, the characters might be manipulated as prototypes by the author's desire to deliver a specific message. Such reading is reinforced by the fact that Moorish characters in the poem are either invented or impossible to identify historically. Menéndez Pidal identifies only King Yúçef of Morocco as a real historical figure, linking him to Yúsuf ben Texufin (1059-1116), who was the first Almoravid ruler (En torno al poema 17-18). The image of the historical Cid, a mercenary knight who served both Moorish and Christian sovereigns, differs considerably in the poem and in Arabic sources, where his image is closer to the historical Cid, giving rise to the so-called cidofilia and cidofobia among the researchers of the poem (Daniel, The Arabs 81; De Chasca 74). As a result, the Oriental characters are prone to manipulations. Thus the poem offers a solid ground for analyzing the formation of Orientalist relationships between Christians and Moors. 
Religion in the Cantar yet again becomes the litmus paper that reveals the sociopolitical division of society. All the actions of the Cid are determined by his religious affiliation, which is presented to the audience in a manner that contrasts with the apparent lack of religious fervor on the part of the Other, thereby reinforcing the gap between the dominant and the subaltern cultures. The Cid and his men are blessed with victories and ganancias, profits, ${ }^{11}$ which does not contradict the biblical notion ${ }^{12}$ of a good Christian. ${ }^{13}$ The religiousness of the Christian protagonisis contrasts with the lack of religious dedication on the part of Muslims and Jews in the poem ${ }^{14}$. Both subaltern cultures in the Cantar, the Muslims and the Jews, are constantly compared, directly or tacitly, to the Campeador. They are defeated by Christians, morally or physically, and even poetically: the author sometimes shows surprising negligence towards the Other.

On one hand, during the battle against King Yúçef of Morocco, one of the Christian characters, Albar Salvadórez, imprisoned by Yúçef (v. 1681), suddenly appears (v. 1994) combating the Moors along with the other Christian knights. On the other hand, when it comes to rewarding the Other for his loyalty and service, this Other is somehow "forgotten" in the poem (Menéndez Pidal, En torno al poema 51). Both times, when The Cid promises to compensate the Jewish moneylenders, Raquel and Vidas, and the Moor Avengalvón, who accompanied the Cid's daughters to Valencia, the text never mentions if the Christians actually fulfilled their word. Whether the payment or reward actually took place remains unknown. And even if it did, apparently, this fact is completely irrelevant for the narrator, as both Jews and Muslims occupy a secondary position in the poem compared to the Christians. However, while these two groups share the fate of being an Orientalized Other, they are not treated equally. They differ in the Cantar in 
several respects: their occupation, their perception of themselves in relation to the Christians, and their perception of the Christians. As a result, the Orientalization mechanisms differ for these two Others, indicating a divergence in the Orientalization path in Iberia.

The Jewish Other in the poem is represented by Raquel and Vidas, the two moneylenders who helped the Cid financially when he was banished by King Alfonso. The profession chosen for Raquel and Vidas in the poem is indicative of their social status. The author deliberately reduces the interaction between Christians and Jews to a stereotypical perception, handling money, thus reducing the importance of the other aspects of such interactions. He follows the general tendency of ostracizing the Jews that preceded the ostracism of the Muslims (Daniel, The Arabs 262). It is sometimes alleged that the author gives female names to the Jewish characters to underscore their low position in society. However, both of these names could refer to original Jewish male names. Raquel can be a derivate of Raguel, and Vidas, which means "life" in Spanish, could possibly be a translation of the Hebrew name Hayyim (Song of the Cid 113). Both Jewish characters are presented as outsiders and representatives of the lowest echelon of society. It is reflected both in their actions and in the way the Christians treat them. It is interesting that throughout the poem, when somebody wants to say "everybody," the expression used is "moros e cristianos" or "non . . moros nin a cristianos" ("Moors and Christians"; "Not the Moors nor Christians"; Poema de mio Cid III.128-2729, I.9-107; The Poem of The Cid 179, 11). Thus the Jewish Other is simply excluded from society. The author portrays them as such, as a peripheral culture existing next to the Christiancentric society. 
To separate them even more from the other members of society, the author makes sure that the Campeador does not interact with the moneylenders directly, but always through one of his vassals. When asked by one of them, Martín Antolínez, to lend money to his banished sovereign, the moneylenders do it readily, even though the Cid's words are transmitted by a messenger. In the poem, Raquel and Vidas constantly worry about their profit. "Nos huebos avemos en todo de ganar algo," ("In any business / we must gain something"), they say to Martín Antolínez, who comes to Raquel and Vidas on behalf of the Cid (Poema de mio Cid I.9-123; The Poem of The Cid 11). But, as the author indicates, because they cannot see past the profit, they are made fun of in the Cantar as the Cid fools them, leaving two chests filled with sand instead of gold.

Even the process of lending money is under Christian control at all times. Raquel and Vidas are under constant pressure. It seems that the Christians are certain about the loan and its conditions (which are imposed by them on the moneylenders and not otherwise), and do not want to waste their time on negotiations (Smith 218). Later, after the conquest of Valencia, Raquel and Vidas follow the Cid's men and request their money back. But they have no bail from the Cid and they have to agree to lose their profit in order to recover the principal. They say to another of the Cid's men, Minaya Álvar Fáñez: "Desfechos nos ha el Çid, sabet, si no nos val; / soltariemos la ganancia, que nos diesse el cabdal. ... /Si non, dexaremos Burgos, ir lo hemos buscar" (Poema de mio Cid II.83-1431-1438). "The Cid has undone us you may know; if he will not aid us; / we shall ignore that interest if he give back the capital. . . . / If not, we shall leave Burgos and go to seek him in Valencia" (The Poem of The Cid 97). 
In the poem, despite all the negotiations, the bard never mentions whether the moneylenders received their loan back, showing a drastically different approach from the principle of fairness that is used towards the Christian warriors and their ganancias. A similar approach to the Jewish Other can be found in other documents of the period. Joseph Duggan compares the Cantar and the other chronicles of the period that describe the Cid's relationship with Raquel and Vidas. It is interesting that in the Crónica de veinte reyes, the second meeting with the moneylenders is omitted altogether; therefore, they never had a chance to ask for their money back. In the Estoria de España, they receive back only the original loan, 600 marks, without any of the interest promised to them by the Cid's people (Duggan 18-19). And it is surprising that despite the trick and the fact that the reader never sees the Cid or his people paying the moneylenders back, we, as Francisco Acaso says, "amamos más a Rodrigo" ("love Rodrigo even more”; 85).

The Orientalization of the Other in the poem is possible only if the reader shares the same values as the bard. The reader identifies with the Cid and stands against the Other. While Christians and Moors present a dichotomy, the Jewish Other has no place in this equation. It is not certain that the bard himself was an anti-Semite, but the events of the poem surely demonstrate the general anti-Semitism present during that epoch (Bandera Gómez 127). As portrayed in the Cantar, Raquel and Vidas seem to accept their lower position. That is, the moneylenders accept their subordinate position as the other vassals of the Campeador, but they do not receive the same patronage as the others.

Therefore, the nature of Orientalism in case of the Jewish Other is different. It is not the relationship between dominated and dominant cultures, but rather dominant and peripheral. The main characteristic of such marginalizing Orientalism is the alienation 
from hegemonic society. Jews are separated from both Christian and Muslim characters by their status; unlike them, they are never represented as noble. While religion plays a crucial role in differentiating between these two groups, the religious aspect is never even alluded to in the case of the Jews. Likewise, Raquel and Vidas are portrayed as nonpertinent to the nobility and, therefore, reduced to outsiders in the Cid's society. If the Muslim Other is a substratum of the kingdom of Alfonso VI, the Jewish Other is an adstratum. As such, they are outside the established social hierarchy. ${ }^{15}$

The Muslim characters constitute another group Orientalized by the hegemonic culture. While they share some of the characteristics of the previous group, the Jews, the path of Orientalization in their case differs from the marginalizing Orientalism described above. Moors, both allies and rivals of the Cid, are also secondary to Christian warriors. Most of them are fictitious, which already indicated the path of reimagination of the Moorish Other chosen by the author of the Cantar. Like Raquel and Vidas, most of the Moors, except for Avengalvón, are not given a chance to speak. The poem lacks an expanded description of any of the Moorish characters, leaving the reader in the dark to guess about their character. During the battles, the adjectives that constantly accompany the Moors allude to enormous losses of goods and people, which become the Cid's booty. Their fear or helplessness is depicted considerably more often than their courage, as in the battle for Alcocer: "moros e moras començaron a llorar" ("the Moors and their women / fell to weep"; Poema de mio Cid I.46-856; The Poem of The Cid 59). Neither the Moorish army nor their kings are as skillful, thoughtful, or successful in their attacks as the Christians. As a result, the Moors in the Cantar become easy victims of Christendom. Norman Daniel points out that in the poem, "the Moors are deliberately 
terrorized ... Most Moors are the objects of contrived terror, to be robbed, slaughtered or sold as slaves" (The Arabs 2). This is true both for the noble Moors and for the masses represented by soldiers and civilians.

The conversion to or from Islam, and Islam itself, are never mentioned in the poem. But, as Theresa Sears notes, religion plays a crucial role in the identification of the Muslim Other (43). In literary studies the Cantar is often accused of lacking the spirit of the Reconquest or the Crusades, as it fails to portray the religious clash in Iberia (De Chasca 74-75). However, the religious supremacy of Christianity is tacitly present in all the elements of the poem: from the descriptions of the characters to the evaluation of the results of military campaigns. While the Cid's men launch their attacks in the name of God, their adversaries never mention the name of the Supreme Being. Hence, they are acting without God or without knowledge of Him (a version that complies with the Medieval perception of Islam as a sum of heresies). While the Cid is treated almost like a biblical hero, Moors, in this case, are the biblical antihero, against whom Christendom is tested. While God protects the Cid and his men in their campaigns and rewards them with goods and lands, Moors are seen to lack this patronage. They lose their belongings and their lives, which for the author is a clear indication that they are in God's disfavor. Thus, religion becomes one of the defining criteria of the relationships between the Christians and the Moorish Other, and therefore, one of the main characteristics of the Orientalization of the Moors in the Cantar. As in the Crusades, the ultimate object of Holy War was to prove that God was on their side.

Another important factor is the social position of the Moorish Other. Some of the Moors are noble, but never as noble as the Christians. However, the "good" Moors like 
Avengalvón are regarded by the author as nobler than the "bad" Christians like the Carrión family. Nevertheless, the poem never dwells on their origin describing the leaders of the Moorish army very briefly, such as Rey de Sevilla, Rey Tamin, Rey Búcar, and "Rey de Marruecos" ("King of Morocco"), the only Muslim leader to actually have a historical referent. Curiously, in the poem even the Cid's Christian rivals and those who envy him, such as Count García Ordóñez, the Count of Barcelona, the Heirs of Carrión, and others, are all characterized in detail, and, most importantly, all are named. In contrast, most of the Moorish characters, even the kings, are anonymous. A name is a crucial element in most cultures: it reflects the person's self. Its absence can indicate a deficiency of character or a lack of importance and uniqueness.

Most of the Moors in the Cantar are portrayed as warriors, who are treated very differently from the Jewish Other. As De Chasca observes, despite the fact that most of them are the Cid's enemies, the bard almost never uses any derogatory epithets when describing them (except on one occasion when referring to the Moorish king Búcar). Analyzing De Chasca's observation, Bandera Gómez concludes that the Cantar was written following an idealized ethic, not so much on Christian values and ideas, as on monarchic loyalty and the trustworthiness of subjects (54-55). This approach leads to the treatment of the noble Moor with as much respect as a Christian knight, a deference to nobility that becomes part of the process of Orientalization of the Other determined by its reimagination.

However, the distance between the hegemonic and subaltern cultures is always present. Moorish warriors are always depicted as slightly inferior to their opponents. They are strong, but not as strong as the Christians; they often lose the battles quickly. 
Here a process of historical ellipsis takes place, the same strategy that the author applies to the Cid's biography. It consists of conscious omissions of facts, which might glorify the Moors. One of the best examples of these omissions is the conquest of Valencia. The Arabic sources thoroughly describe the historic events preceding and following the conquest of this city by the Cid. This description is radically reduced in the Cantar. A similar process can be observed in the Christian Chronicles, where the Moorish century rule was often dramatically compressed. Such compression is an indication of the rapid passage from history to folklore (Daniel, The Arabs 90). Therefore, the selective memory and, as a result, the reimagination or reinvention of the real history are key elements in the construction of the Cantar and define the Orientalization of the Moorish Other.

It is important to note that while Moors are portrayed collectively, there is one character that stands out. It is the Cid's ally, alcaide Avengalvón, one of the Moorish noblemen whose lands were under the Campeador's protectorate. While other Moors underwent a process of reimagination, Avengalvón is not only reimagined but also accepted by the Christians almost as an equal. Norman Daniel points out that "Moors are occasionally allies and may always become friends. They may be more truly noble, and 'my Cid' cares what they think of him ... Treachery to an allied Moor is despicable; the Moor 'Avengalvón' is the Cid's only friend among his peers, his other friends are followers" (The Arabs 2). The Cid calls Avengalvón "amígol . . . sin falla," an "unfailing friend," which indicates the respect for the Moor (Poema de mio Cid II.84-1528; The Poem of The Cid 103). The Cid trusts Avengalvón, as he asks him to escort his daughters to Valencia once Alfonso VI allows them to rejoin the Cid. When the Heirs of Carrión 
decide to return to their lands after the marriage, it is Avengalvón who senses their future betrayal and discovers their plans of murdering him and taking his possessions. At this moment, Avengalvón gives a speech that defines his character and his perception by the author and, therefore, by the reader:

¿Dezidme, qué voz fiz, infantes de Carrión!

yo sirviéndovos sin art, a vos conssajastes mie muort...

Dios lo quiera y lo mande, que de tod el mundo es señor,

D'aqueste casamiento ques grade el Campeador. (Poema de mio Cid III.128-2675-2685)

Tell me, what harm have I done you

Heirs of Carrión!

I serve you without malice

and you plot my death. ...

May God, who is Lord of the world

will and command

that the Campeador may remain

content with this marriage. (The Poem of The Cid 177)

Among Moorish characters only Avengalvón is accepted by the Christians. The speech reveals the reasons why this Orientalized Moor differs from the others. First and foremost, Avengalvón brings the name of the Lord to attest to his words and to the evil deeds of the Carrión, something unusual for the Moors in the poem. Once again, this fact 
stresses religion as a key factor in the process of building the new social hierarchy in the Cantar and placing the Other in it. Secondly, Avegalvón presents himself as a loyal servant of the Cid and his new family. He brings the readers' attention to the fact that he served the Heirs of Carrión as he served the Campeador. At the same time, he is considered an equal among the other vassals of the Cid, as can be seen in his greeting of Minaya, whom he hugs and kisses in the shoulder following a Moorish tradition, while a vassal would greet his patron by kissing his hand (Poema de mio Cid II.83-1515-1525).

Finally, Avengalvón's speech reveals another important fact. While the idea of revenge, both military and personal, is often found in the enemies of the Cid, both Christian and non-Christian, Avengalvón demands only Supreme justice and mercy for the Heirs of Carrión, restraining himself from their direct punishment. Similar humility is one of the core values of a true Christian, who should seek only a Heavenly revenge, not a human one. In the same way, at the end of the poem, the Cid leaves the revenge of the Carrión family in the hands of God. It is God who guides the Campeador's men in their duel with the Carrión, and brings the Cid not only the victory, but a more important reward: the marriage of his daughters into two ruling families. Therefore, Avengalvón represents a type of Europeanized Moor, reinvented by the dominant society that is looking into accepting him and making him a part of its hierarchical structure.

These two distinctive paths of Orientalization, the marginalization and the reinvention of the Other, will have repercussions in later literary works and national imagery. Won over by his admiration of the Cid's virtue, the Moor Avengalvón has taken a first step towards embracing the Christian civilization, and as a result he is on the other side of the barricades, helping the Christians. His speech reveals the main characteristics 
of the Orientalization process that will become popular soon after the end of the Reconquest: it is the appropriation of the Other through the process of reinvention. Avengalvón, however, despite being treated almost as an equal, is not given full protagonism in the poem compared to his Christian counterparts. Hence, the process of appropriation of this Orientalized character in the Cantar is at its initial stage. Nonetheless, it is an important step in the development of Hispanic Orientalism.

\section{$\S$ 3. The Renaissance: The Sentimental Moor Caught in the Shift of Power}

The development of the Orientalist paradigm in Iberia went hand in hand with political changes. As the Reconquest was coming to an end and the Peninsula witnessed dramatic changes in the distribution of power, there was a significant increase in the number of cultural, linguistic, and social interactions. The inhabitants of Iberia felt threatened by the Other, but the Iberian Crusade was "too steady for European fears to focus on" (Daniel, The Arabs 80-81). Therefore, it had a lesser impact on the panEuropean imaginary. Meanwhile, the movement to unify Spain dictated the need for further segregation into "us" and "them," reimagining and including in the social hierarchy those who complied with Christian ethics and roundly refusing those who did not. This situation resulted in the expulsion of the Jews (1492) and the Moriscos (1609), as well as further Orientalization of those who remained in the Iberian Peninsula.

The Renaissance Peninsula distinguished itself in remarkable ways from the previous period. The evolving nature of the relationship between Spaniards and Moors became evident then. The Oriental Other lost its connotation as the enemy and started to 
lose its connections with historical reality. The Other began to appear more often in literary depictions of the past, rather than in official historiography or accounts of the present. This situation gave way to a process of romantization, a further reinvention of the Other that led to the acceptance of such Orientalized, non-threatening Muslim in the popular mentality of the time. The Moor became more of a fairytale character than a historical figure.

Such preconceived image of the Oriental Other had a significant impact on both literature and history. The literary text, however, was an easier and more reliable medium for perpetuating the myth. Its initial subjectivity was concealed by the objectivity claims (Menocal 3). Hence, increasingly Orientalized Muslims make their way into literary works. Two prominent texts of the period, El Abencerraje y la hermosa Jarifa (1565) and Guerras civiles de Granada $(1595,1604)$, exhibit noteworthy changes in the perception of the Oriental Other. Both works were written after the end of the Reconquest but recreate Iberia's historical past from the perspective of the victorious Castilian culture. Therefore, the shift of power and the change in people's perceptions were reflected in the ways that both works portray the Other and recreate its Orientalized image.

Already in the Cantar, there was a tendency to idealize the reinvented image of the Other in order to include it in Christian society. The mechanisms and peculiarities of such "positive" Orientalization can be found in El Abencerraje y la hermosa Jarifa, the story depicting the period in Spanish history preceding the end of the Reconquest. Since El Abencerraje y la hermosa Jarifa was published during the Renaissance, the time gap between the events described in the story and the actual time of creation determined the Orientalization path of its characters. As Claudio Guillén notes, "El Abencerraje alludes 
to contemporary history by means of silent contradictions. It offers a vision of peace and unity against a background of past wars between Christians and Moslems, while connoting contemporary struggles and religious conflicts" (178). Thus, El Abencerraje becomes one of the best examples of a reinvented and idealized Other that was turned into a propaganda tool for Spain's absolute monarchy. Consequently, the relationship of Hispanic Orientalism to the discourse of power, as well as the type of relationships between Christians and the Oriental Other (juxtaposition versus hierarchy) become crucial elements that determine the development of the original paradigm.

The first three known versions of El Abencerraje appeared almost one century after the end of the Reconquest in the years $1561-1565 .{ }^{16}$ The 100-year gap allowed the author to reinvent or reimagine the story in accordance with the new historical circumstances and demands. The temporal distance between the sixteenth-century narrator and the fifteenth-century setting gave the storyteller an opportunity for redrawing history, and with it, the Oriental characters. The verisimilitude of the newer version of events resides in what Wayne Booth called "the undramatized narrator" (152). The storyteller not only created a suitable image of the Moorish warrior Abindarráez from the famous lineage of Abencerrajes, but in order to convince the audience of its authenticity, he pretended to experience the same feelings as a reader. The storyteller dives into the story along with his audience, and this has an immediate impact on the power of the text to impress. The audience can even identify with these characters (Wright 256). Such connection between the reader and the text could not happen in earlier literary works, like the Cantar de mio Cid, where the reader most likely would identify with the Christian knights. Therefore, the fact that the reader is sympathetic to the Oriental Other and 
recognizes his own values in the Other's, is indicative of the acceptance of the Orientalized (but domesticated) Other by the dominant society.

The narrator wisely chooses the third person to appear neutral and credible, as the audience is less likely to perceive the author's manipulation of the characters (Rico 4142). Nevertheless, the gap between him and the narrated events is obvious. Thus some linguistic techniques are used to make the Orientalized Other even more credible. One of them is the creation of a special semantic entourage for each of the characters, words that appear in association with them. Such type of "coaching" of the audience is an effective method for creating a stable stereotypical image of the Other that henceforth will appear in later literary works.

In the story, the author first establishes an approximation to what would be the ideal goal of all the Orientalized characters. Such ideal is embodied by the Christian protagonist Rodrigo de Narváez, governor of Álora. His name always appears couched in epithets and values such as "the greatest virtue," "gallant," "noble," "honor," etc., emphasizing his chivalry, courage, and strength. This semantic field creates the image of an ideal knight who is emotionally, physically, and spiritually superior to his adversaries, both Christian and Muslim. Rodrigo de Narváez is admired by both for his invincible moral values, as portrayed in the story of the married lady, where he preferred to guard his friend's honor rather than follow his own feelings: "Pudo más con él la honra del marido que la hermosura de la mujer" (Lama, and Peral Vega 80); “The husband's honor influenced him more than the wife's beauty" (López Estrada, and Esten Keller 73).

The story of forbidden love is parallel to Abencerraje's love story. However, the latter could not avoid the temptation, and the lovers were forced to escape. The nobility 
and worthiness of Abencerraje are also constantly compared to those of Narváez. The latter is a model knight fighting for his king and the wellbeing of the country, deeply respected by both Christian and Moorish societies. While Abencerraje is also portrayed as a skillful and noble warrior, it is Narváez who saves him in the eyes of the King of Granada. In response to his letter asking to absolve the two lovers, Abencerraje and Jarifa, who broke the rules by getting married without their parents' permission, the Moorish king answers: "Sábete que ninguna cosa me pedirá el alcalde de Álora que yo no lo haga" (Lama, and Peral Vega 85); "And know that I refuse nothing the Governor of Álora asks me to do" (López Estrada, and Esten Keller 83).

The image of Narváez created in accordance with the code of courtly love is idealized. He becomes a perfect vessel to transmit the universal values of honor and honra embedded in the notion of the perfect Christian knight, as theorized by Erasmus and Castiglione. Such image also serves the political agenda of the author supporting the Christian dominance in the Peninsula. The simplified structure of the image of the Christian hero was already observed in the Cantar de mio Cid. Even though the immediate Muslim threat diminished with the end of the Reconquest, the authors of the period often fell into what Manuel Álvar called "maurofilia"- the idealized, romanticized view of the vanquished Moor (58). Luce López-Baralt indicates, however, that the very existence of "maurofilia" in the times of the Inquisition is "uno de los enigmas literarios más importantes de la literatura peninsular" ("one of the most important literary mysteries of Penisular literature"; 149). As a consequence, even during the Renaissance, it was important for the author to establish the Christian dominance, as the consolidation of the Spanish Empire was not yet complete and there was an urgent need to reiterate the 
claims of not only Christendom, but Spaniards themselves. It was also the time, when Catholicism faced the advance of Protestantism, a new menacing enemy of the traditional Church. Thus, Narváez presents a very convenient standard, against which the storyteller tests the Moorish Other and Orientalizes it to serve his own political interests. During the early Renaissance, unlike later periods when the Spanish Kingdom consolidated its European and American dominance, setting such standard plays a crucial role in the process of Orientalization of the Other. It serves as a measuring scale, as the paradigm of the relationship with the Other was not fully established yet.

As before, during the Renaissance the Orientalization process does not affect all social strata to the same degree. The Moorish protagonists, as their Christian counterparts, are always of noble origin, like Abindarráez, whose story occupies a considerable part of the narrative, and Jarifa, the daughter of the King of Granada. Only such adversaries could be compared to the ideal, created in the Spanish literary and oral tradition. However, the tendency to reimagine these protagonists resulted in their fabulization, the loss of connections to historical reality. The fact that the life and adventures of Abencerraje and Jarifa were very popular themes of romances fronterizos (frontier folk poetry), which preceded the publication of the story, only reinforced this tendency, as historicity was not the main purpose of the romance fronterizo. Therefore, the interpolation of real and fictitious elements was natural in this type of literature (Wright 255-56). It facilitated the process of reinvention of the Other, which intensified exponentially from the romance fronterizo to El Abencerraje y la hermosa Jarifa.

As the author establishes the yardstick for the Other, he re-creates Abencerraje as a mirror image of Narváez, adding an Oriental flavor to it. The same linguistic tools are 
used to describe this character: words of Arabic origin, as well as parallel semantic structures, thus intensifying the contrasts and the similarities between the respective representatives of the hegemonic culture and the Other: "Vieron venire por donde ellos iban un gentil moro en un caballo ruano; él era grande de cuerpo u hermoso de rostro y parescía muy bien a caballo. Traía vestida una marlota de carmesí y un albornoz de damasco del mismo color" (Lama, and Peral Vega 52); "They saw a noble Moor on a roan stallion advancing over the road they had been following. He was of heroic physique and handsome countenance, and he sat his horse expertly. He wore a crimson marlota and a damask burnoose of the same color" (López Estrada, and Esten Keller 47).

As both protagonists are noble, their personal characteristics are very similar: they are brave, honorable, and skillful, in other words, exceptional. The narrator is amazed by the nobility and strong values of the Christian knight Narváez, as well as those of Abencerraje. He praises the grace and the elegance of the Moor along with the Christian protagonists of the story. But it is the final remark by the Orientalized Other that becomes a quintessence of the Orientalization process in El Abencerraje: "Quien pensare vencer a Rodrigo de Narváez, de arma y cortesía, pensará mal" (Lama, and Peral Vega 88); "Who thinks to surpass Rodrigo de Narváez in arms and courtesy, thinks erroneously" (López Estrada, and Esten Keller 83).

The appraisal of Narváez coming from a Moorish nobleman may seem at first as a confirmation of Christian values that became a scale by which to measure the Other. Nevertheless, the meaning of this phrase goes beyond this superficial reading. The very fact that it is an Oriental Other that recognizes Christian values indicates that Abencerraje underwent a process of reinvention and, as a result, idealization by hegemonic society. 
Therefore, his words reaffirm the traditional values of the absolutist Spanish Kingdom: monarchy, nobility, and the so-called pureza de sangre (blood purity). ${ }^{17}$ Those are European values accepted and adopted by an Orientalized Moor. The real Moor, therefore, is replaced in Spanish popular imagery by an Orientalized (domesticated) Moor, a la Spain, whose ideals reinforce the hierarchical social structure, which was considered a clear reflection of the celestial one, according to the prevailing Neoplatonic attempt to still hold on to a vanishing medieval worldview. Such Moor is seen as a possible member of courtly society, a follower of the supposedly universal code of courtly love, thus initiating the process of appropriation of the Other.

It is interesting that Abencerraje while adopting Christian values related to the nobility follows the so-called código caballeril (chivalric code) of the late European Middle Ages. When describing his entrance into the scene, the narrator portrays the Moor as a Provençal knight. His image, created by an intricate combination of colors and shapes, reminds an experienced reader of the novelas de caballería (chivalric romances). The pattern of the relationship between Abencerraje and Jarifa - the common childhood memories, the forbidden love, the escape, the punishment, and the happy ending - can be easily recognized by the reader of this type of novels. Therefore, it is clear that the figure of the Moor in El Abencerraje y la hermosa Jarifa is reinvented, in other words, Orientalized, and this Orientalization has a political motive. It eliminates the menacing differences between culturally diverse entities in the Peninsula, which seeks to complete the foundational process of creating a homogeneous nation. This would go along perfectly with the expulsion of Moriscos and other reforms that had a similar goal. 
The parallelisms in the life story and character of the Christian and Moorish protagonists gave the author the necessary basis for the reinvention of the Renaissance Oriental Other. The new Oriental then is idealized in the same way and included in the social hierarchy, with the Moorish Other, naturally, placed below his Christian counterpart. According to López Estrada, this is the reason why in El Abencerraje y la hermosa Jarifa the idealized relations between Moors and Christians are fused with the plot of the novel (Wright 259). It provides for an image of a romanticized Moor, "a Moor whose moral code and whose habits are essentially those of Christians" (Deferrari 12). Deferrari also argues that Abindarráez represents the "anomaly of a gentlemanly Moor" who becomes one of the founding images of a sentimental Moor (10). This image closely resembled the Christian protagonists of chivalric novels, confirming the idealization path that Hispanic Orientalism took after the end of the Reconquest, when the Moor was no longer dangerous.

Therefore, the main characteristics of Hispanic Orientalism, which were present since the Reconquest, namely the reinvention and idealization of the Other, intensified and developed further during the Post-Reconquest period. The maurofilia that became customary in Spanish literature legitimized the figure of the idealized Other in popular imagination. It led to the gradual substitution of the real Moor by his Europeanized version who speaks like a Christian, feels like a Christian, even reads the same books and operates with the same imagery seen in chivalric novels. Most importantly, as it can be seen in El Abencerraje y la hermosa Jarifa, he accepts the Christian founding values of the absolute monarchy. This acceptance initiates the process of appropriation of the Other by hegemonic culture, through an Orientalization mechanism that can be described as 
intended "for the Moor, by the Moor, but without the Moor." The figure of the Orientalized Other becomes a puppet in the hands of canonical writers and historians. As a result, the real nature of the relationship between dominant and subaltern cultures remains silenced in the documents and the narrative.

\section{§ 4. The Spanish Kingdom: A Search for Unity and the Europeanization of the Other}

The capture of the Kingdom of Granada played a crucial role in the history of Spain, as well as affected the relationships between the Old Europe and the foreign Other. The previously established peninsular literary paradigm of relationship with the Oriental Other had already established itself in the popular imagery and even in official documents and chronicles. For instance, the Moorish protagonists of Ramon Muntaner's Chronicle were often amazed by Christian superiority and even recognized it openly, similar to Abindarráez in El Abencerraje y la hermosa Jarifa: "When the King of Granada saw the marvelous deeds performed by the Lord King of Aragon and his followers, he held himself for lost, for he had not thought at all that there was so much strenuousness and so much valour in them" (235). There are very few documents that present this Christian-Islamic opposition from the point of view of the Other, the Moors. One of these documents, the Arabic chronicle Nubdhat al-'așr, points out that the surrender of Granada was a prepared act by Granada's king Boabdil, and not a spontaneous decision based on the current military situation. According to the author, the king simply fooled the people by gathering all noblemen whom he consulted on this 
matter, but many alleged that he and the military chiefs "had already made an agreement to hand over the city to the Christians." Such conspiracy was the reason why the Catholic Kings "readily agreed" to Boabdil's proposal and were "happy to grant all their requests and stipulations" (Nubdhat al- 'așr 251). In fact, had the articles of the Capitulation of Granada been carried out, the Muslims in the Iberian Peninsula would have enjoyed similar benefits as had the dhimmis under Muslim rule. Among those benefits were the free exercise of Islam, the preservation of the mosques, the use of Muslim law, shari'a, among Muslims, tax alleviation, etc. ${ }^{18}$ (Capitulation of Granada 345-47). In reality, many of the clauses of this agreement remained on paper only.

After the end of the Reconquest, the search for a unified Spanish kingdom became a priority. The expulsion of the Jews (1492), the subsequent expulsion of the Moriscos (1609-1610), and the constant obsession with purity of blood led to an increased desire in people to affirm their lineage. Those outsiders who remained in the Peninsula were forced to blend in. In many cases, it meant adoption of Christianity as well as the customs and habits of the Spaniards. The literature of the period contributed to the process of unification by juggling with the image of the Other. While previously the negative image of the outsiders, for instance Muslims, invaded peninsular and European literature, during the Renaissance a shift towards the "noble Saracen" is observed. Nina Dulin-Mallory, while tracing the parallels between these two powers, points out one such example, the Saracen Plomides, who possesses all the virtues of a great Christian knight (qtd. in Blanks, and Frassetto 6). The image of a Muslim nobleman was being reinvented and was merging with that of the Christian warrior. However, this was the case in narrative. In 
reality, by contrast, despite the disappearance of the direct Islamic threat, social segregation continued to exist.

The memoirs of the period indicate that there was a considerable gap between Christians in Europe and the remnants of the Muslim invaders. One of the testimonies of cultural and religious segregation in the community is Lettera $V$ by Andrea Navagero, the ambassador of Venice in Spain. After having visited the south of the Iberian Peninsula in 1526, he wrote:

Los moriscos hablan su antigua y nativa lengua, muy pocos quieren aprender el español; son cristianos a la fuerza y están poco instruidos de nuestra fe, en esto se pone poquísimo cuidado. . . . Son muy enemigos de los españoles, que no los tratan por cierto muy bien. Las mujeres todas visten a la morisca, que es un traje muy fantástico . . . todas se quiebran los pechos para que crezcan y cuelguen mucho ... usan mucho los baños. .. . Dicen que en tiempo de los moros el rey de Granda tenía más de cincuenta mil de a caballo; hoy no hay casi caballero, y la gente que queda es plebeya y vil, salvo muy pocos. (317)

The Moriscos speak their old native language; very few of them want to learn Spanish. They are forced into Christianity and know little about our religion, and very little care is placed on their instruction. They are very hostile towards Spaniards who, as a matter of fact, do not treat them well. The women all dress Moresque style and their dresses are very extravagant. They say when the Moors ruled here, the King of Granada 
had over 50,000 cavaliers. Now, there is hardly a nobleman here; the people who stayed are plebeian and vile, except for very few. ${ }^{19}$

As it can be seen from the letter, cultural and religious segregation continued beyond the Reconquest. The reality described by Navagero differs considerably from that of El Abencerraje y la hermosa Jarifa. It reveals the hostile environment that reigned in the reconquered Peninsula. Even assuming that Navagero's perception is somewhat partial, it still reveals the downfall of Moorish culture in newborn Spain and the attending societal segregation.

Despite the reignant differences, in Spanish narrative, the memories of the opposition between Christians and Muslims were fainting, and the process of reinvention and appropriation of the Oriental Other went faster and faster. Illustrative of this tendency is the work of Ginés Pérez de Hita, Guerras civiles de Granada. A predecessor of the modern historical novel, it was published in two volumes that differ significantly in style $(1595,1604)$. The first part combines both historic and fictional events, narrated in the style of the chivalric novel. It describes the Kingdom of Granada in its last period before the Christian conquest and its most eminent representatives, the Zegríes, the Abencerrajes, and other lineages. The second part is less flowery in style and is closer to the real historical events. It narrates the campaign against the Moriscos during the second half of the sixteenth century following their revolt against Christian rule in 1568.

The first part of Guerras civiles de Granada represents a romanticized image of life in the Kingdom of Granada before its fall in 1492, very similar to that found in El Abencerraje. As Shasta Bryant indicates, facts and fantasy are so interpolated here that sometimes it is impossible to see the real historic entourage in the narration vividly 
seasoned by Pérez de Hita's imagination. However, there is literary and historic evidence that the events described in the novel are rooted in the chronicles of the period, such as Crónica de los Reyes Católicos (1565) by Hernando del Pulgar and Compendio histórico de las Crónicas de España (1571) by Esteban Garibay y Zamalloa (Bryant xiii). At the same time, it is important to note that fantasy in Guerras civiles does not result in an abundance of supernatural events, so typical of the chivalric novels (Zaid 316). It can be attributed to Pérez de Hita's desire to create a chronicle of the period, rather than another novel of chivalry. Therefore, the author bases his descriptions on actual reality, modifying it to his own taste and that of his audience. This important fact indicates that the vector of Orientalization is descending, and the literary tradition shaped the image of the Other, coaching the readership to recognize this image, thereby forming a stereotype in its mind.

Critics strongly disagree about the historical value of Guerras civiles de Granada. Some scholars, such as Marcelino Menéndez y Pelayo, assert that the Moors in the novel are "galantes, románticos y caballerescos, alancedores de toros ... son convecionales en gran parte y no dejan de prestarse a la parodia y a la caricatura ... de los pastores de las églogas" ("galant, romantic and chivalric, bull fighters; they are mostly conventional and even lend themselves to a parody and caricature of the shepherds from the eclogues"; ccclxxxvi). For Menéndez y Pelayo they are Christians dressed up in Moorish garb. Giorgio Valli also argues that the novel represents an imaginary, picturesque Arabic lifestyle, which is far distanced from the truth by virtue of the author's imagination. Therefore, he considers Guerras civiles a chivalric novel, rather than a novela morisca, a Moresque novel (26). 
Even though the presence of chivalric motifs is indisputable in the work, some scholars oppose such categorization of the novel. Even though they recognize the Europeanizing tendencies in Guerras civiles, they do not attribute such manifestations to the fact that it is merely a chivalric novel lacking a real historical background. In their opinion, the proximity of Christendom and its traditions, and the constant movement of mercenaries, such as the Cid, led to the inflection of Arabic culture in the Peninsula with elements of Christian culture and habits. As evidence, Paula Blanchard-Demouge points to numerous chronicles, including Jhata by Ibn Aljatib, which she considers as one of the most influential. They all mention, for instance, that for years Moors participated in Christian festivities, such as Christmas and St. John's day (Introducción, Primera parte 1xxv). Juridical documents of the period also attest to the fact that Moors often attended important Christian festivities (Meyerson 338-39). Therefore, according to this second point of view, Pérez de Hita did not invent most of what he described, although some critics like Blanchard-Demouge admit that imagination played an important role in his narrative. ${ }^{20}$

However, despite the radical difference regarding the vector of Orientalization in these two points of view, the outcome of both processes is rather similar. Whether the Moorish Other was reinvented and romanticized to fit into the European mores, or whether the court of the king of Granada indeed assimilated to the lifestyle and customs of its Christian neighbors, at the end of the sixteenth century both were likely to be portrayed in Orientalist fashion. As Rhona Zaid states, the predominant attitude among sixteenth-century Spaniards was "the feeling of quasi tolerance, rather than acceptance" towards the Moorish Other, which lead to Orientalization (328). Similarly, the author 
offers his testimony to the reader, either by Orientalizing the events or by reporting the Orientalized image, already established in the popular imagery (or both).

The first part of Guerras civiles shows many signs of interpolation of Christian and Islamic cultures, staring with the chivalric plot of the narrative and the courtly lifestyle of the Moorish knights, the love triangles, and the battlefield as a way to solve such conflicts. The protagonist, in this case a whole lineage of Abencerrajes, is passing through the usual routine: their loyal service to the king, their betrayal by antagonists, in this case the Zegríes and their allies, and finally the protagonists' revenge and restitution of their honor and status. Thus, the main stages of Guerras civiles coincide with those of the formative novel or Bildungsroman, which later becomes one of the mechanisms of reinvention of the Oriental Other. The Abencerraje's relationships with their Christian opponents in the battlefield and outside of it become a litmus test that reveals the new facets of the Hispanic Orientalist paradigm. In this sense, the Orientalization techniques in Guerras civiles are slightly more sophisticated than in El Abencerraje y la hermosa Jarifa. If in the latter, the Moorish king explicitly accepts the Christian values' dominance ${ }^{21}$ only at the end, in the first part of Guerras civiles de Granada, the Oriental Other not only behaves like a Christian, but also thinks and speaks like one from beginning to end. So, ultimately, as the Muslim threat diminished, Pérez de Hita can benevolently allow himself to display, as Luce López-Baralt notes, "el propósito expreso de dignificar la casta perseguida y promover el espíritu de reconciliación y armonía entre la cristiandad oficial y los descendientes de los musulmanes" ("the express purpose of dignifying the persecuted ethnic group and promoting a spirit of reconciliation and harmony among official Christendom and the descendants of the Muslims" 150). 
Therefore, the reinvention and Europeanization of the Oriental Other is expected, and the process of appropriation of the Other by hegemonic society observed in El Abencerraje appears as fait accomplit in Guerras civiles.

Clear evidence of cultural interpenetration and appropriation of the Other in the readers' eyes is the mixed use of images and allusions to Muslim, Christian, as well as Ancient Greek and Roman historical figures and realities. Even though Pérez de Hita attributed the authorship of Guerras civiles to Aben Hamin, an Arab historian whose writings were purportedly translated by Pérez de Hita, it is important to note that these diverse cultural images are used in the author's remarks. They also disclose the basis for the Orientalization process that Pérez de Hita imposes on his readers. In the descriptions of Muslim warriors either by the author of by other Muslim and Christian characters, typical European imagery also serves as a common reference to emphasize characteristics of the protagonist. One of the most recurrent images is "el fiero y sangriento Marte" ("fierce and sanguinary Mars"; ${ }^{22}$ Pérez de Hita, Primera parte 100, 163). One of the most active Moorish characters, Reduán, is compared to "el famoso Alejandro o César," ("the famous Alexander or Caesar"; 97). Such mode of Europeanization is one of the strategies of appropriation of Other by the dominant culture.

The Moors are not only compared to the legendary warriors and gods of European tradition, but they themselves are made to employ these images, completely understanding the nuances and showing great knowledge of European history, especially of a period when Islam was not yet instituted as a religion. For example, the Moorish knight Almoradí says that the civil wars of Granada are "tan crudas como aquellas tan memorables de Silla y Mario" ("as cruel as those very memorable [civil wars] of Sila and 
Mario"; Pérez de Hita, Primera parte 201). In other words, he finds his reference in the events that took place in the first century BC, when the above-mentioned leaders of two opposing groups committed several cruelties, for which they are famous. Another recurrent Christian reality in the novel is St. John's day. It is mentioned consistently throughout the first hundred pages, as there is a "fiesta muy solemne, el día de San Juan" (“a very solemn day, St. John's day"; Pérez de Hita, Primera parte 77). It is difficult to imagine what, other than the Christian tradition of celebrating this holiday, could possibly lead to a Moorish celebration on that day. Even if there were such a reason, the fact remains that in the author's eyes this celebration occurred on a day dedicated to St. John.

Besides these obvious Europeanizing elements in Guerras civiles, there are several metatextual connections with other texts that portray European Christian values. These references once again confirm that the authorship could not belong to an Arab historian, as he would use a different set of references in his work. The Orientalization from inside allows the author to create a more convincing image of the Other, as well as to conceal from the audience the rebranding techniques. First and probably most relevant for Guerras civiles is the biblical influence. Several parallels can be traced between the Bible and the novel. The author describes the lineages and enumerates the geographic locations, mimicking the biblical descriptions not only in meaning but even in syntax. ${ }^{23}$

This parallelism and other instances of interconnectedness of the two texts indicate the intention of the author of Guerras civiles to create an almost biblical, in other words, an essential and exhaustive narration of life in the kingdom of Granada. The author sought to create an encyclopedic three-dimensional world that his contemporaries and future generations could use as a reference. The novelistic form is more entertaining 
than a chronicle; it would be accessible to more readers, widening its influence on society. Therefore, its images, including those of the Orientalized Other, would be more likely to become a classic or traditional referential source.

The interactions between Muslims and Christians in their everyday life and in the battlefield define the essence of the Orientalist paradigm for the period. There are three main groups of characters that can be distinguished in the novel: the Christians and the two antagonist Moorish groups, led by the Zegríes and the Abencerrajes. The image of the Christians follows the tendency already established in the literary tradition of the Peninsula: they are benevolent, magnanimous, and noble. Their kindness to the defeated Moors conquers the hearts of their enemies and leads to their continuous admiration. Christian excellence is constantly mentioned in the novel: "la bondad del Meastre" ("the kindness of the Maestre"); one of the Moorish warriors, Alabez, tells the Christian knight don Manuel "tu bondad me obliga" ("your kindness obliges me") (Pérez de Hita, Primera parte 34,75$)$. Almost all the military campaigns of the Christians are successful, and the author never misses the opportunity to bring it to the readers' attention: "quedaron los cristianos con singular victoria" ("the Christians scored a remarkable victory"; 14). As a result of the exacerbated praise, the image of the Christians is significantly idealized. Like the image of the Oriental Other, it is also reinvented and polished, and thus, simplified; however, unlike the Moors, the Christians are placed at the top of the hierarchical structure of the society.

The other two groups, the opposing Moorish lineages of the Zegríes and the Abencerrajes, are also widely accompanied by epithets and comparisons, particularly in the first part of Guerras civiles. However, these two groups are defined and placed in the 
social hierarchy according to their relationships with the Christians. Pérez de Hita does not do it directly, but his comments on the actions of both groups reveal the author's preferences. While the brave Abencerrajes are always the winners of the skirmishes either on the battlefield or during the numerous military exercises held in the court of the king of Granada, the evil Zegríes, as well as the other less important members of the opposition, such as the Gomeles and the Mazas, "les tenían mortal odio y envidia" ("hated and envied them to death"; Pérez de Hita, Primera parte 56). The conclusion that the author draws after characterizing the two rival groups is of great importance. He sees the success and leadership of the Abencerrajes as a consequence of their allegiance to the Christians: "eran, finalmente, amigos de los cristianos" ("were, after all, friends of Christians"; 56).

The idea of the relationship between social position and allegiance to either of the two parties is repeated in different ways throughout the novel, making the Abencerrajes the legitimate successors of the Christians. The qualities that they possess are similar to those praised in the Bible. Among them, charity is constantly referred to: "caridad a los cristianos ... porque los bienes el santo Alá los da para que se haga bien por su amor, sin mirar leyes" ("charity for Christians as Allah Almighty gives to people to do good things because of His love regardless of religion"; 135). Therefore, the hierarchy of the three groups present in the novel is the following: the Christians, then the group led by the Abencerrajes, and finally the Zegríes and their followers. Consequently, the Abencerrajes are closer to the top of the social ladder in the author's eyes as a consequence of their proximity to Christianity and their acceptance of core Christian ideas and values. It is also of great importance that the Moorish characters from both groups are of noble origin. 
The Moors from lower classes are never mentioned in the first part of the novel, not even the servants of the Moorish noblemen.

The main differences between Christianity and Islam are manipulated by the author in order to create a stereotypical, Orientalized image of a good Moor and a bad Moor. Even though Medieval reality places these two religions in opposition, they have one major doctrine in common: the existence of the one and only one God. Monotheism is never questioned in the novel, whether by Moors or by Christians. Nonetheless, one of the major reasons for the segregation of Christianity and Islam, the figure of the Prophet Muhammad, serves as a litmus test to reveal the nature of Orientalism in Medieval Spain. Twice in the novel, the author directly expresses the dominance of the Christian tradition. In both cases, it is the Moor who recognizes the superiority of Christianity. It usually happens when he is facing one of the biggest challenges of his life. For instance, when Albyaldos is mortally wounded by Maestre, he asks the victor to baptize him: “Albayaldos ... dijo que quería ser cristiano.... Y allí Maestre le echó del agua sobre la cabeza, en nombre de la santísima Trinidad, Padre, Hijo, Espíritu Santo, le llamó don Juan" ("Albayaldos said he wanted to become Christian. And there, Maestre poured water over his head and called him Don Juan in the name of the Holy Trinity, the Father, the Son and the Holy Spirit"; Pérez de Hita, Primera parte 123).

A more obvious example of manipulation of the theological differences between Christianity and Islam can be seen in Chapter X, where Sarrazino loses an important tournament and with it, his faith in the Prophet. However, despite that, it never occurs to him to reject the idea of the one and only God. Therefore, Sarrazino finds a perfect solution: to follow Christianity, the religion where his new ideas fit perfectly: 
¡Oh Mahoma traidor, perro pérfido engañador, y en el tiempo que habías de favorecer mis esperanzas me faltaste! Di, perro, falso profeta ¿yo no te había prometido hacerte de oro todo, si me dabas victoria en tal jornada como ésta, y quemar grande cantidad de incienso en tus aras? . . Pues vive Alá, don falso Mahoma, que por oprobio tuyo que me tengo de tornar cristiano. Porque es mejor su fe, que tu secta mala y llena de engaños, y esto yo lo cumpliré como caballero, y doquira que oyere tu nombre he de blasfemar dél. (Pérez de Hita, Primera parte 90-91)

Oh perfidious and deceitful Mahomet! at the moment you ought to favored me most, you deserted me. Do you forget, false enemy, that I promised to raise your statue in gold and to burn a load of incense in your mosque, if you had this day given me victory? I find you have not the power to assist me, as therefore, as Alla lives, I will be revenged of you by turning christian, and following that holly religion: thus only can I save my soul from eternal perdition! (The Civil Wars of Granada 123) ${ }^{24}$

These situations exemplify the process of reinvention and appropriation of the other by the dominant culture. They show that the Europeanized Moors are the only Other accepted by Christian society. They form part of the social hierarchy and are placed one step below the Christians. The Moor who does not accept Christianity is still included in the social hierarchy, but is placed even lower. The reason for the inclusion of both Europeanized and non-Europeanized Moors is that they underwent a process of alteration in order to be understood and accepted by the dominant group. These 
alterations consist, first and foremost, of the erasure of radical differences between the opposing religions, Christianity and Islam. Even though one of the representatives of the Zegrí linage, Albin Hamad, affirms that "o el moro, moro; o el cristiano, cristiano" ("let the Moors be Moors and the Christians be Christians"), even the negative characters in the novel experience a considerable influence of Christian society (Pérez de Hita, Primera parte 135).

Throughout the novel there are numerous references to Moorish and Islamic traditions and customs, such as the sacred month of Ramadan, the Muslim prayers, alzalá, ${ }^{25}$ etc. (Pérez de Hita, Primera parte 55, 156). However, not all of these elements are used properly, revealing their artificial character and decorative role in the novel, which contribute to the process of reimagination and reinvention of the Oriental Other. One of several examples is the use of precious metals, in particular gold. The court of the king of Granada is constantly described as pompous, and precious metals are used everywhere. In the case of gold, even though in the Islamic tradition this metal is not banned, men are forbidden to wear it. Despite that, it is common in the novel to see personal objects made of gold in possession of the Moorish knights. In the following passage, the everyday use of the golden objects is especially obvious: "el moro . . . sacando una sortija del dedo, de oro muy rica, que era con la que sellaba, se la dió al Maestre" ("the Moor, taking a golden ring that he used as a seal, off his finger, gave it to the Maestre"; Pérez de Hita, Primera parte 114).

The plot against the queen in the later chapters of the novel is one of the best examples of the author's manipulations of Muslim reality. As Blanchard-Demouge indicates, there is no correspondence between the scene of the queen's betrayal and any 
of the romanceros of the period. Hence, most likely, it is the author's imagination, nourished by stories about rivalry in the harem that brought to life the queen's accusation of adultery (Blanchard-Demouge, Introducción, Primera parte lxv). When the king of Granada is warned by one of the Zegrí knights that he saw "la reina holgar con Albinhamad" ("the queen consorting with Abinhamad"), he accepts the accusation with only two witnesses, Mahandin Gomel and the accuser himself, Hamete Zegrí (Pérez de Hita, Primera parte 171). Yet, according to the Qur'an, in order to prove such a crime, the accuser has to produce four witnesses. ${ }^{26}$ Later, the king arranges a duel, very common among knights in chivalric novels, to decide who is right, the queen's accusers (the Zegríes and their supporters) or the defenders of the queen's honor (the Abencerrajes and their followers). Apparently familiar with Islamic traditions, the author has four representatives of each group fight for the queen, instead of simply witnessing the crime a minor inaccuracy in the eyes of his readers, but a major mistake in the eyes of a Muslim, as it misinterprets the Qur'an. Such blend of traditions and cultures shows that the Other underwent a process of Europeanization and is only accepted as such by the dominant society.

The second volume of Guerras civiles de Granada differs significantly from the first. The second book is written using contrast as a literary technique. Historical events not only serve as a backdrop, but are a central part of the narration, as Pérez de Hita himself was a witness and an active participant in the military campaign against the Moriscos in 1569-1571, following their revolt in Alpujarras. The author seems to forget about the glorious lineages copiously described in the first part. His narration is more dynamic in comparison to the almost static first part where the reader encountered long 
descriptions of a single event. The amorous adventures are left out as well. It is half way through the second part that the author introduces some scenes typical of the first part, such as a Moorish knight's veneration of his lady, a courtly balcony scene, and several love triangles whose protagonist is the beautiful Zahara (Pérez de Hita, Segunda parte $153,156-57,163,219-25)$. Nonetheless, these scenes only serve as a short break for the reader between the descriptions of the military campaign. Indeed they resemble the comic pieces inserted during the intermission of Ancient Greek tragedies to relax the tension and prepare the spectator for the next episode. The second book shows a Pérez de Hita who appears more familiar or more careful in his descriptions of Moresque lifestyle and customs. ${ }^{27}$ Despite that, the process of Orientalization of the Other follows the general tendency of reinvention and appropriation found earlier.

Some researchers, such as Paula Blanchard-Demouge, argue for a difference in the nature of Orientalism between both volumes. She admits that the Oriental motives and the way of treating the Moorish characters in the first part underwent a process of alteration. She suggests that it is in the second book that a true Orientalism can be found (Blanchard-Demouge, Introducción, Segunda parte xxxi). ${ }^{28}$ However, her definition of the term Orientalism is limited to the representation of the true-to-life Orient. It does not reflect the relationship between Christian and Islamic cultures, but rather centers on the more realistic description of the Moriscos in Spain. In this sense, the second book indeed is more accurate in depicting the Oriental Other in the Iberian Peninsula. Nevertheless, given the understanding of the term Orientalism as proposed in this study - as a process of interaction and interpolation of different cultural selves - the accuracy in depicting this type of relationship in the second book of Guerras civiles is debatable. 
There are several parallels between the two parts of the novel, which bring them close together despite their apparent differences. There are semantic and syntactic parallels, including the concepts of noble lineage and purity of blood. Nobility is manifested in both Moors and Christians, and is significantly more prominent in the second part of Guerras civiles, which features characters from different social strata. The conflict between plebeians and noblemen, both of Moorish and Christian origin, underscores the fact that social hierarchy is much stronger in the second book. It seems that the upper class is contrasted with the lower class, and in this process, it is the lower class that always appears corrupted or lacking in morals.

Even the greater realism of the second part serves to emphasize the hierarchical structure of society. Pérez de Hita, who himself faced the scenes that he described later in Guerras civiles, feels obliged to report the cruelties and abuses perpetrated by the Spaniards, for instance, during the battle of Felix when the uncontrolled Christian troops slaughtered helpless Moorish women. Pérez de Hita unfolds a horrifying picture in front of the readers' eyes. He says the Moorish women:

. . confiando en la christiana misericordia hazían cruzes de unos pequeños palos $\mathrm{y}$ hincaban de rodillas, llorando $\mathrm{y}$ temblando dolorosamente dezían: “¡A mí, christiana, señor; a mí, christiana!” Mas el endiablado esquadrón, no usando de aquella misericordia que las pobres y desventuradas Moras esperavan, las hazían mil pieças y a otras les hazían saltar por fuerça de aquellas peñas abajo. (Segunda parte 79) 
... relying on Christian mercy, they were making crosses with little sticks and falling on their knees. Shivering painfully and crying, they were saying: "Me Christianize, sir, me Christianize!" But the bedeviled squadron, not making use of the mercy that the poor unfortunate Moorish women hoped for, would cut them into a thousand pieces, and made the others jump off the cliff and fall on the rocks.

Pérez de Hita himself condemns such rage: “ $\mathrm{O}$ crueldad terrible de los Christianos, jamás vista en española nación! ¿Y qué furia infernal te incitava a hazer tanta crueldad?" ("Oh, terrible cruelty of the Christians never before seen in the Spanish nation! What kind of infernal fury was instigating you to commit such a cruelty?"; Segunda parte 79). At the same time, despite the gravity of the crime, he is not completely on the side of the Moorish women. Once again, purity of blood wins, as the cause of the cruelty is explained by the weaknesses of the Christian lower class: Palomares, a simple soldier, supposedly instigated the entire slaughter. Therefore, only the upper class, represented by Marqués de Vélez, much venerated by Pérez de Hita, cares about its image and about being a good Christian. Similarly, the descriptions of the Christian knights, like Don Luys Fajardo, are very elaborate and resemble descriptions of legendary heroes. In contrast, the Oriental Other is often referred to only by nationality as "Turco" (Turk) or "Africano" (African).

Whereas the realism of the second part constitutes a significant departure from the first part, Pérez de Hita's evaluation of his contemporary society remains the same. The "immunity" that he grants to the noble Christians only becomes more obvious in comparison with the lower class crimes. The author also attaches typical concepts of 
nobility, compassion, etc. to the image of a noble Christian: "el buen Francisco Zervantes lleno de compassión (natural cosa de Christianos dolerse de aquellos que les fallece fortuna)" ("the good Francisco Zervantes full of compassion (as it is natural for Christians to feel for those who are unfortunate)"; (Segunda parte 24). Religiosity in the second part is as important as in the first. God helps Christians in all instances in both books. For example, when the Moriscos wanted to attack Granada during Christmas, according to the author, God made it snow heavily, so that the enemy could not start his attack.

A true noble Christian who is at the top of the hierarchy is a firm believer: “Christianos somos y Christianos tenemos de morir, y viva el Rey nuestro Señor . . . más queremos la paz que la guerra" ("We are Christians and we will die Christians, and long live the King. We want peace more than war"; Pérez de Hita, Segunda parte 24). This position is quite opposite from what the Moors say about their religion: in both parts of the novel, several of them end up praising Christian values or even converting. Unlike noble Christians, their nobility and, therefore, all their positive qualities are not innate. Even the noble Moriscos are not exempt from the lower instincts, as when they betray Reyecillo, their newly proclaimed king: "y entonces se tuvo por más perdido, entendiendo que de sus camaradas era vendido, porque tenía aquella gente morisca por mudable y $\sin$ fe ni ley a la verdadera amistad, como ya tenía visto por las cosas passadas" ("and then he felt he was completely lost, as he understood that his companions betrayed him, because he knew that these Moriscos were changing sides and did not follow any religion or law, despising friendship, as he could deduce from things that had happened earlier"; "Pérez de Hita, Segunda parte 24). The very title of the 
Moorish king, Reyecillo, formed with the diminutive suffix -illo, already indicates the relationship of dominance between the Christians and the Moriscos: there is only one king in Iberia, and the others are "reyecillos."

Hence, the image of the Moriscos in the second book does not differ radically from the first book. In both parts of the novel, the Oriental Other undergoes a process of reinvention and appropriation by Christian society. It is manipulated to fit the mainstream hierarchical paradigm of the newly founded Spanish nation. Included as part of this hierarchy, the reinvented Other ceases to present a menace to absolute monarchy or to Christianity.

\section{$\S 5$. Conclusion}

During the Reconquest and post-Reconquest, the shifting powers in the Iberian Peninsula allowed for the formation of a certain stereotypical perception of the nondominant cultural group, the Other. After the European self successfully launched the process of Reconquest, the foreign Other started to be associated with the invaders, the Muslims. These relationships between the dominant and the dominated sociocultural groups are Orientalist in nature, as it is the dominant group that imposes certain criteria on the subaltern Other. It took several centuries for the original Orientalist paradigm in the Peninsula to be formed. The impact of cultural encounters eventually became imprinted in both, individual and literary memory, being reflected in the Orientalist paradigm and making its features more prominent and recognizable. 
Several factors played a major role in the Orientalization process, natural for an Iberia struggling for national and mental unity. Religion was by far the principal factor in the differentiation between the Iberian "us" and the Other. Moreover, the impact of this factor in the perception of the Other was so strong that its remnants can be found in twenty-first-century literature and politics. The desire for uniformity and, therefore, for a more manageable and less complex society, is one of the crucial factors that define the vector of Orientalization. As the process of unification of the Spanish kingdom progressed, the mechanism of dividing society into Self and Other became more and more defined. This dichotomy allowed the Western self not only to define its relationship to the East, but also to define itself through self-comparison to the Other.

Oral and written literary traditions shaped the image of the Other in the Peninsula. The Cantar de mio Cid reveals the distinctive nature of Hispanic Orientalism. In the poem, two Others, the Jews and the Moors, occupy different positions in society, the first by being a peripheral culture, and the second by being a part of the Christian-Muslim dichotomy. The manners of Orientalization differ for both outgroups, as they reflect the balance of power between dominant and subaltern groups. There are thus two methods of Orientalization used in this case: alienation (marginalization) and reinvention.

In the other milestone work for Hispanic Orientalism, El Abencerraje y la Hermosa Jarifa, the Orientalization mechanisms are much more defined in comparison to the Cantar. Here, the Oriental Other finds its niche in the hierarchical structure of Castilian Christian society. The "Otherness" of the real Moors is gradually erased by including them into the dominant culture. This way, the subaltern culture becomes easy to understand and relate to, while the figure of the Orientalized Other becomes a puppet 
in the hands of official writers and historians. Therefore, the dominant society begins the process of appropriation of the Other through its reinvention, while more realistic manifestations of the Other found, for instance, in Arabic Chronicles are simply silenced.

While in the previous two works, the Orientalist paradigm could be referred to as going through the formation process, it is in Guerras civiles de Granada where it reveals its full potential. The two stylistically different parts of the novel only prove the sustainability of the Orientalization process in post-Reconquest Iberia. The newly formed Spanish nation appears more confident to include the Oriental Other in its social structure by manipulating its image and reinventing it to fit the pre-established hierarchy. Only the Muslim Other of noble origin is considered part of the Hispanic social structure. Nevertheless, this Other can never reach the same position as a Christian, who in turn is openly and universally admired. Thus, the main characteristics of the original paradigm of Hispanic Orientalism include the reinvention and Europeanization of the Other, or, more generally, reshaping the Other to fit the values of the dominant culture. This leads to the appropriation of the Other in order to rule more effectively by creating a more uniform society. The more the Oriental Other mirrors the values and ideas of the dominant society, the more he is admired. The authenticity of this recreated image is not questioned in the oral and written literary traditions as they are presented to a contemporary audience. This way, over time, what was an artificial creation would become tangible in the popular imagery. Consolidated through this process over several generations, the original paradigm was now ready to be exported to the New World. 


\section{NOTES}

${ }^{6}$ The transliteration of Arabic words is done according to the IJMES system (Journal of Middle East Studies). As such, unlike other words, the proper names are not italicized and the diacritics are not used in them, except in the use of 'ayn and hamza (the initial hamza is also dropped).

${ }^{7}$ The linguistic map of Iberia during this period is also of great importance and interest. Beside the presence of several pure romance languages and dialects, as well as Semitic languages, there are multiple examples of mutual linguistic influence, like the case of aljamiado, which used the Arabic alphabet to transcribe a text written in a romance language. On the other hand, we have kharjah (jarcha) and muwashshah (moaxaja), lyric poetry written in an Andalusian dialect of Arabic, significantly influenced by the surrounding Romance dialects.

${ }^{8}$ It is an interesting fact that the Sephardic Jews, banished from Christian Iberia in 1492, were officially welcomed back to Spain only in 1992. In that festive ceremony, Prince Felipe of Asturias addressed the representatives of the Sephardic community, inviting them to rediscover their land of origin. This symbolic act that happened five centuries after the expulsion of the Sephardic Jews once again points out the enduring nature of Orientalism and the intent on both sides to overcome their differences. This process, nevertheless, is as intricate and problematic as any other. Even though the event in 1992 was received with acclamation, a severe criticism of Spain's passive position in the whole process continues to be raised. For example, José Luis Abellán from Universidad Complutense states: "En esta hora en que se impone una nueva remodelación de la escena internacional, España podría dar un ejemplo de buena voluntad y prestar un apoyo positivo al proceso de planetarización, incentivando sus relaciones intelectuales con una comunidad sefardí que ... mantiene vivas sus raíces españolas" ("Nowadays, in the recent process of restructuring international relations, Spain could give an example of good will, positively supporting the globalization process, by promoting its intellectual relationship with the Sephardic community, which still keeps its Spanish heritage alive"; Abellán).

${ }^{9}$ Karen Armstrong uses the following transliteration: jizyah (200-01). However, for the sake of uniformity, the spelling used in this research follows the IJMES guidelines.

${ }^{10}$ During the rule of Alfonso X the Wise (1221-1284) the School of interpreters of Toledo rescued various Greek, Arabic, and other manuscripts from oblivion. Among the translators there were not only Spaniards, but also Sephardic Jews and Arabs, including famous ones like Jehuda ben Moses Cohen, Isaak ibn Cid, Abraham Alfaqui, Thabit ibn Qurra, and al-Battani. It is symptomatic that while working with scientific manuscripts, the translators used the word "Arabic" and not "Saracen" to refer to the 
origin of the tracts. Benjamin Kedar argues that this arose from the fact that "Arab" is a linguistic or ethnic reference, while "Saracen" points to the religion, Islam (90-91). Therefore, the translators, valuing knowledge itself, tried to neutralize the impact of the religious opposition and its effect on the translated works. Norman Daniel also points out the importance of the translation of Arabic texts during this period, as they conveyed both Arabic thought infused by the translators and the experience of reading the original ancients Greek manuscripts. Among the translated texts were the works of such eminent representatives of their time as al-Farabi, al-Ghazali; medical writers like Ali ibn alAbbas al-Majusi (Haly Abbas), Ibn Butlan; doctors and philosophers like ar-Razi and Ibn Sina (Avicenna), and Jewish writers familiar with Arabic culture like Ibn Jabirol and Musa ibn Maymun (Maimonides). But it is the translation of Ibn Rushd (Averroes) that would be one of the most influential for Western civilization, as it was a vehicle for Aristotelian thought more than "Averroism," which Daniel considers partly a nineteenthcentury invention (The Arabs 274-77).

${ }^{11}$ Even though at first, Daniel's view of the legendary Cid seems exaggerated, it is nevertheless, fairly accurate. It is hard to argue that the protagonist of the Cantar differs from the real historical Cid, who indeed was a mercenary at the service of both Christians and Moors and, as a consequence, led the typical life of a professional warrior, fighting and gaining or losing his assets depending on the outcome of his campaigns. At the same time, the theme of acquisition of money and goods as a result of military victories is not hidden from the reader. For instance, the word "ganancia" ("profit") is quite recurrent in the poem, along with other words of the semantic field of trade, such as "marcos" ("marks"), a type of currency used during the period; "oro y plata" ("gold and silver"), etc. In fact, the Cantar distinguishes itself from other epic poems by displaying an extraordinarily detailed financial account of the military campaigns (Duggan 19). The Cid gains lands and goods as a result of his military actions and trades these possessions as a good merchant. He keeps Valencia, an important city, but sells Alcocer to the Moors for "tres mil marcos de plata," "three thousand silver marks" (Poema de mio Cid I.44845; The Poem of The Cid 58). The Cid sells what will not bring him much profit or is difficult to maintain, and manages the rest of his possessions extremely rationally:

Los moros y las moras vender non podremos, que los descabeçemos nada non ganaremos; cojámoslos de dentro, ca el señorío tenemos; posaremos en sus casas e dellos nos serviremos. (Poema de mio Cid I.31619-622)

We cannot sell the Moors and their women, it would gain us nothing to cut off their heads; Let us take them in 
for we are the lords here;

we shall live in their houses

and they shall wait upon us. (The Poem of The Cid 43)

${ }^{12}$ See: "Jehoshaphat and his people proceeded to collect the plunder and found much among them, including goods with the bodies and precious articles. They stripped off for themselves more than they could carry, spending three days collecting the loot; for it was enormous" (The Holy Bible. The Berkley Version, II Chronicles 20.25; my emphasis).

${ }^{13}$ On the other hand, it seems that the author does not see any contradiction between the nobility of the Cid and the loot he obtains as a result of a military exploit. Even his nickname, El Campeador, the Champion, is associated in the poem with both aspects of the victory: the battle itself and la ganancia, the profit. The absence of any sharp distinction between these can be explained in various ways, but considering the importance of religion during the period, it is impossible to overlook the similarities between the actions of the Cid and those depicted in the Old Testament. Considering that the Cantar omits the part of the Cid's biography when he served the Moorish sovereigns, all his remaining actions aim at the reconciliation with Alfonso VI and the defense of the "true" faith. In order to stress the king's supremacy and despite being unfairly treated by him, the Cid sends Alfonso several valuable presents. The Campeador does it to assure the king of his loyalty even after the king has pardoned him.

It seems sometimes that the author makes the Cid a rival to Alfonso VI, challenging the latter, as the king is constantly falling for the rumors about the evil plans or disobedience of the Cid. There are two remarks in the poem that paraphrase each other, one about the Campeador and the other one about his king. The author, saddened by the Cid's banishment by Alfonso, exclaims: "Dios, qué buen vassallo, si óbviese buen señore!" (Poema de mio Cid I.3-20); "God, how fine is the vassal / Were his lord but worthy! (The Poem of The Cid 5). When the Cid makes his men rich by selling Alcocer to the Moors and distributing the money among them, the bard notes: "Qui a buen señor sirve, siempre bive en deliçio" (Poema de mio Cid I.45-850); "Who serves a good lord / lives always in delight" (The Poem of The Cid 58).

As it can be seen, the conflict between Alfonso and the Cid starts at the very beginning of the poem. These lines not only contrast the two characters, but show the reader the dominance of the Cid, who does not passively enjoy the achievements of his vassals, but engages in dangerous campaigns to defend his faith. At the same time in the Cantar in contrast to the historical Cid, the Campeador never questions the hierarchical system and the nobility of the king. These characteristics are the ones that distinguish the Cid from the rest of the knights and the king himself, who does not trust the noble blood of the protagonist. As Cristina González states, "aunque el Cid en ningún momento piensa destronar al rey, en cierto modo, con la gloria que ha alcanzado, lo destrona. El hombre más poderoso de España no es el rey de Castilla, sino el héroe castellano" 
("even though the Cid never wanted to dethrone the king, in a way, he did it; he dethrones the king with all the glory he achieved. The most powerful man in Spain is not the king of Castile, but the Castilian hero"; 178). This idea is forced upon readers when the author calls his protagonist "mio Çid Roy Díaz el Castellano" ("Ruy Díaz, the Castillian / My Cid") instead of using the name of the place the Campeador is originally from, the city of Vivar (Poema de mio Cid I.38-748; The Poem of The Cid 58).

${ }^{14}$ As a true defender of the Christian faith, the Cid always invokes God and the Virgin Mary to attest to his words or deeds. He launches all his campaigns "en el nombre del Criador" ("in the name of the Creator," Poema de mio Cid I.34-675; The Poem of The Cid 47). As soon as he obtains his first victories and even before sending tributes to King Alfonso, the Cid donates money to celebrate one thousand masses in the Cathedral of Burgos, from where he parted to his exile (Poema de mio Cid I.41-820-825). After he reconquers Valencia, one of the first things the Cid does is to confirm "buen cristiano" Don Jerónimo ("good Christian") as the bishop of Valencia (Poema de mio Cid II.781300; The Poem of The Cid 89). The significance of this action is emphasized by the bard: all the heads of the Cid's army and his closest friends, like Álvar Fáñez or Minaya, are extremely happy about this decision. The whole Christian world celebrates the installment of a bishop to minister over the newly recovered territories: " $D$ Dios, qué alegre era tod cristianismo, /Que en tierras de Valençia señor avie obispo!" (Poema de mio Cid II.79-1305-1306); "God, how great was the rejoicing /of all those Christians, / for in the lands of Valencia / there was a lord bishop!" (The Poem of The Cid 89).

For the protagonist, it is especially important to establish a religious authority in the reconquered territories, considering that the caliphates were religious states, and all influential political concepts and institutions in Medieval Iberia, even the religious ones, were called "ley" ("law"). Therefore, a bishop consolidates the authority of the church over the region. In this light, the protagonist's religiosity for the author of the Cantar is beyond doubt. The Cid is the quintessential Christian knight defending his faith and his motherland. Clearly, this indicates that the author of the Cantar sees the Cid as a man of God who protects Christianity and supports the institution of the monarchy and the idea of the unification of the Peninsula under one firm rule. In the poem, the Cid regains territories lost to the infidels, who occupied them "illegally" in order to spread their religion. According to the "divine will," those lands were assigned to the Christians. This situation markedly resembles the texts of the Old Testament, where the twelve tribes of Israel constantly fought for the Promised Land. They not only defended it from the attacking tribes, but also fought those who stayed in their lands and spread their pagan religions. A significant part of the description of such battles is the list of all the enemy's belongings, which the tribes of Israel had gained by courage and divine favor. One of such descriptions presents the aftermath of the encounter between the Judah king Jehoshaphat and the men of Ammon, Moab, and Mount Seir: "Jehoshaphat and his people proceeded to collect the plunder and found much among them, including goods 
with the bodies and precious articles. They stripped off for themselves more than they could carry, spending three days collecting the loot; for it was enormous" (The Holy Bible. The Berkley Version, II Chronicles 20.25; my emphasis). The word choice in the description is of considerable interest. It openly presents the nature of the process without hiding or disguising it. The same process can be observed in the Cantar. The booty that the Cid acquires after one of his campaigns is as amazing and as directly described as in the Bible (my emphasis):

Esta alberga los de mio Çid luego la an robado

de escudos e de armas e de otros averes largos;

de los moriscos, quando son llegados,

ffallarom quinientos e diez cavallos....

Traen oro y plata que non saben recabdo ... (Poema de mio Cid I.40-794796b, 799)

My Cid's men have sacked the Moors' encampment seized shields and arms and much else of value; when they had brought them in they found they had taken five hundred and ten Moorish horses.... They bear so much gold and silver they do not know how much there is. (The Poem of The Cid 54-55)

${ }^{15}$ It is stressed even more by the way Raquel and Vidas are addressed by the Christians (mostly by their names), in contrast with the descriptive titles given to the Cid. If the language of the characters defines them in the poem, as Malcolm Read says, the Jewish Other is obviously silenced in the Cantar (4-5). It seems that in the poem, the existence of such peripheral Other does not affect society in any significant way, and the latter interacts with them only when it feels the necessity to do so.

${ }^{16}$ One version of this legend was published in the Chrónica, another version was inserted in the Book of Diana by Jorge Montemayor, and finally, the most elaborate version appeared in Inventario by Antonio de Villegas.

${ }^{17}$ Blood purity refers to the long-known ancestry of noble Christian origin.

${ }^{18}$ According to the Capitulation of Granada, there were several benefits guaranteed by the Catholic Monarchs to the citizens of the Kingdom of Granada. The document mentions specifically two geographic locations, Granada and Alpujarras, the inhabitants of which would benefit from the treaty. However, there is a slight distinction between the rights of the inhabitants of these two places. The Capitulation of Granada contains numerous clauses that give considerable benefits in terms of migration, religion, taxation, etc. Some of the most important clauses are the following: 
Their highnesses and their successors will ever afterwards . . . allow King Abi Abdilehi ... and all the common people ... to live in their own religion, and not permit that their mosques be taken from them ...

No Christians might enter mosques where the Muslims perform their prayer without the permission of the alfaquies ...

Their highnesses would not permit Jews to have power or command over the Moors, or to be collectors of any tax.

Law suits which arise between Moors will be judged by their law, sharì'a ... (Capitulation of Granada 345-47)

It is interesting that many of these clauses would be vital for the resolution of numerous conflicts in the contemporary Middle East and the Islamic world in general.

${ }^{19}$ The translation is mine. (S. T.).

${ }^{20}$ For example, in Guerras civiles, there is no indication of the authorship of Aben Hamin that Pérez de Hita claims (Introducción, Primera parte xxix, xxxvii). At the same time, Henry Austin Deferrari traces the resemblance of many of the scenes of feasts, tournaments, court life in Guerras civiles to the ones depicted in contemporary chronicles. Nevertheless, he admits that the image of the Moorish Other presented to the reader both in the chronicles of the period, as well as in the novel, contributes to the perpetuation of an exotic and, therefore, foreign icon of the Other (Deferrari 29-30). In other words, The Moorish Other went through the process of self-Orientalization under the influence of the dominant Western culture. The latter Europeanized him and included him into the familiar Western paradigm. In this case, the vector of Orientalization has the opposite direction. Such image is not imposed on every man. It is the Oriental Other that changes himself, and this new image is then reflected in the literature of the period.

${ }^{21}$ See previously quoted passage: "Quien pensare vencer a Rodrigo de Narváez, de arma y cortesía, pensará mal" "Who thinks to surpass Rodrigo de Narváez in arms and courtesy, thinks erroneously “; Lama, and Peral Vega 88; López Estrada, and Esten Keller 83).

${ }^{22}$ Hereafter, the translations of the First part of Guerras civiles de Granada (The Civil Wars of Granada) are mine, unless otherwise indicated (S. T.). The 1803 English version of The Civil Wars of Granada is highly imprecise. It does not always translate all the text, omitting words in the sentences or even whole sentences. Therefore, this text will be used only when it does not affect the meaning of the Spanish original.

${ }^{23}$ There are several examples of such parallels, especially at the beginning of the novel. For example, in Chapter III, the description of the origins of each of the lineages and the constituents of each of the regions that will be discussed in the text, resemble 
considerably the passages from the Bible (Joshua 15.20-62 and Genesis 36.9-32). See, for instance:

Y con toda esta gente, se fue el valeroso capitán Abidbar hasta la ciudad de Vera, donde era alcailde el bravo Alabez Malique, adonde se acabó de juntar todo el ejército de los moros y alcaides que aquí se nombrarán.

El general Abidbar; Abenaciz, capitán de Baza; su hermano Abencazin, capitán de la Vega de Granada; el Malique Alabez, alcaide de de Vélez el Blanco; Alabez, alcaide de Vélez el Rubio; Alabez, alcaide de Almería; Alabez, alcaide de Cúllar; otro alcaide de Guéscar; Alabez, alcaide de Orce. Alabez, alcaide de Purchena; Alabez, alcaide de Giquena; Alabez, alcaide de Tirieza; Alabez, alcaide de Caniles. (Pérez de Hita, Primera parte 8)

At length he came to Vera where the general rendezvous was appointed, and where one of the noble Malique Alabeces commanded. The army now mastered as follows:

Abidbar, the general. Abenaziz, captain of Baza. Abenaziz, his brother, captain of the troops of the Vega de Granada. Almoradi, Alcayde de Guadix. Malique Alabez of Vera. Alabez of Vélez el Blanco. Alabez of Vélez el Rubio. Alabez of Almeria. Alabez of Cuellar. Alabez of Huescar. Alabez of Orce. Alabez of Purchena. Alabez of Xiquena. Alabez of Tirieza. Alabez of Caniles. (The Civil Wars of Granada 8)

Literal translation of the Spanish text fragment is the following:

And with all these people, went the gallant captain Abidbar to the city of Vera, where the governor was the brave Alabez Malique, and where just gathered all the army of the Moors and governors that will be named here.

The general Abidbar; Abenaciz, captain of Baza; his brother Abencazin, captain of la Vega de Granada; the Malique Alabez, governor of Vélez el Blanco; Alabez, governor of Vélez el Rubio; Alabez, governor of Almería; Alabez, governor of Cullar; other governor of Guéscar; Alabez, governor of Orce. Alabez, governor of Purchena; Alabez, governor of Giquena; Alabez, governor of Tirieza; Alabez, governor of Caniles.

Below is one of the biblical parallels to this enumeration that can be compared to the text, not only in meaning but also in its syntactic structure. This takes the interconnectedness between the texts to the next level: 
7 These are the kings of the land on the west side of the Jordan, whom Joshua and the Israelites defeated from Baal-gad in the valley of Lebanon to Mount Halak, which stands opposite Seir . . .

9 the king of Jericho, the king of Ai which is near Bethel,

10 the king of Jerusalem, the king of Hebron, 11 the king of Jarmuth, the king of Lachish, 12 the king of Eglon, the king of Gezer, 13 the king of Debir, the king of Geder, 14 the king of Hormah, 14)

The king of Arad. (The Holy Bible. The Berkley Version, Joshua 12.7-

24 The translation of the Spanish text is not completely accurate, especially in the last part of the paragraph where the Moor expresses his intention of becoming Christian. The literal translation of the last sentence is: "Because His faith is better than your poor sect full of lies; and I will follow my word as a knight, and everywhere I hear your name [Muhammad] I will curse it." As well, Sarrazino promises to decorate the mosque with gold rather than building a golden statue of Prophet Muhammad. The English translation, therefore, directs the reader to the image of golden calf as a symbol of religious betrayal and failure of this idol to assist Sarrazino. These mistakes in the translation themselves can be an indication of the more contemporary Orientalization processes that take part at the beginning of the nineteenth century. The translator applies the Christian model of the veneration of God to Islam, altering the text to fit this idea.

25 The word alzalá is not currently included in the Dictionary of The Royal Academy of the Spanish Language. The meaning of this word is "a prayer." It comes from the Arabic word al-șalā, (الصلا) that has the same meaning.

${ }^{26}$ The respective passages in the Qur'an are as follows: "And those who launch a charge against chaste women, and produce not four witnesses (to support their allegations) - flag them with eighty stripes; and reject their evidence ever after, for such men are wicked transgressors" (The Qur'an, Surah Al Nur 24.4).

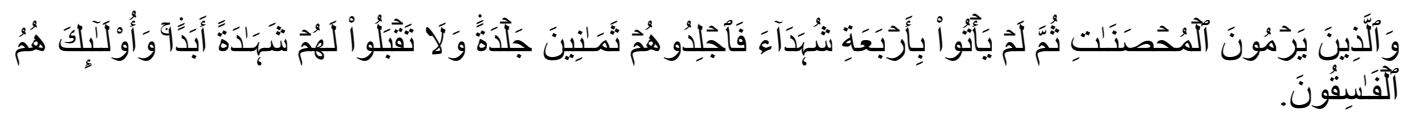

(The Holy Quran, Surah Al Nur 24.4) 
See also: "Why did they not bring four witnesses to prove it? When they have not brought the witnesses, such men, in the sight of Allah, (stand forth) themselves as liars!" (The Qur'an, Surah Al Nur 24.13).

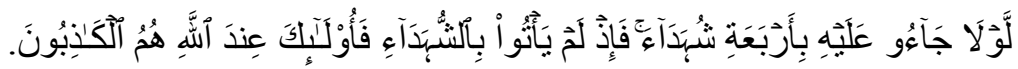

(The Holy Quran, Surah Al Nur 24.13)

${ }^{27}$ In the second book, Pérez de Hita pays more attention to details when describing Moorish life. In the first book, the Moorish men wear gold, something that is against Islam. In the second book, on the contrary, it is silver that is constantly mentioned, as it is a more typical metal for Muslim men to wear: "le pusieron encima de la cabeça una corona de plata dorada y rica, que era de una imagen de nuestra Señora" ("they crowned him with the silver, golden plated crown with the image of Our Lady"; Pérez de Hita, Segunda parte 15).

As well, in the second part, realistic details are abundant in Pérez de Hita's narration, while they are constantly omitted in the first part. This realism is especially obvious in the descriptions of military campaigns. The author often explains the outcome of the battles with natural causes, as "los Christianos enfermos passaron la peor parte porque no podían huyr ni pelear y assí morían muchos dellos" ("the Christians who were sick, suffered the most, as they could not flee nor fight, and, therefore, a lot of them were dying"; Pérez de Hita, Segunda parte 312).

${ }^{28}$ Blanchard-Demouge argues that the description of the Oriental life, depicted in the first book of Guerras civiles, is based on the real life events, described in the chronicles that served as basis for Pérez de Hita. She asks:

¿No hay orientalismo de buena ley en Hita? . . . Analogía entre las aventuras del héroe beduino, su devoción por su dama, su generosidad protectora de los débiles y las costumbres de la caballería europea en la Edad Media. . . Los cronistas españoles testifican este espíritu caballeresco de los moros, refiriendo numerosos ejemplos que ciertamente Hita debió conocer y que contribuirían a la idealización del enemigo que se encuentra en su obra. (Introducción, Primera parte lxxxvii)

Is there genuine Orientalism in Hita? [There is] Analogy between the adventures of a Bedouin hero, his devotion for his dame, his protective generosity towards the weaker and the customs of the European knighthood in Medieval period. The Spanish chroniclers attest this knightly spirit in the Moor, giving numerous examples that Hita most certainly was familiar with. It would contribute to the idealization of the enemy that can be found in his work. 
At the same time, Blanchard-Demouge recognizes that while writing the first part, Pérez de Hita was often driven more by the chivalric spirit of the period than by historical accuracy. As a result, the content is sometimes fictitious, which contradicts the author's original purpose (Introducción, Primera parte $1 \mathrm{xv}$ ). Therefore, she considers the way of depicting the Oriental lifestyle in the first part less authentic: "Si en la obra de Hita quiere buscarse orientalismo, no es en la primera parte, sino en la segunda, donde podemos encontrarle, siendo de un interés verdaderamente histórico, aun cuando fuese menos apreciada y conocida que la primera" ("If one wants to look for Orientalism in Hita's work, it is not in the first, but in the second book that we can find it. The second part has true historical interest, even though this volume is less acclaimed and famous than the first"; Introducción, Segunda parte xxxi). Albeit, it is important to remember that by the term "Orientalism" in this case, Blanchard-Demouge understands the exotic portrayal of Moorish life itself rather than the intricate relationship between the dominant culture and the Other as theorized by Edward Said. 


\section{CHAPTER 2.}

\section{The Appropriation: The Early Colonial Migration of Hispanic Orientalist Paradigm}

\section{§ 1. Introduction}

With the disappearance of the immediate Islamic threat in the Iberian Peninsula towards the end of the Reconquest, the image of the Other became more inclusive rather than exclusive. Under Christian lead and practices, it began to be considered as a part of the social hierarchy. Rather soon after the end of the Reconquest, these inclusive practices changed in nature. With the unifying impetus in the Peninsula on one hand, and the growth and strengthening Ottoman Muslim Empire on the other, Christianity once more felt a possible Islamic threat. This opposition resulted in "purifying" practices in Iberia, such as the expulsion of the Jews (1492) and the expulsion of the Moriscos (16091610). The so-called discovery of America occurred in the times crucial for the construction of European identity, when "the Europeans were themselves in the process of establishing their own myth of cultural homogeneity as the 'West,' defined by exclusion of the "Orient," as well as "the Westernization of Christianity through differentiation from its Semitic roots" (Camayd-Freixas, Controversy 1).

Hernán Taboada insists that the so-called Reconquest of Iberia was not the major moving force behind the conquest of America. He emphasizes the Ottoman threat that was more imminent than the Moorish one, however, "la gigantesca Guerra . . . con el imperio otomano" if often overshadowed by the Reconquest ("a gigantic was against the Ottoman Empire"; 32-33). He goes even further by asserting that the most direct link to 
the Islamic world during the period of Great Discoveries are the maritime wars with the Muslims in the Mediterrenian (Taboada 191). The New World presented one of the greatest opportunities for Europe endangered by the Ottoman threat for the revival and conservation of Christianity in its pure form. It explains the popularity of the Plus Ultra campaign that became widely available to the European self and imagination after its socalled discovery by Christopher Columbus and its exploration by him and other travelers and conquistadors. ${ }^{29}$

However, the expansion of Christianity came second after the main reason for the colonization of the New World, which was the common desire for upward social mobility by taking part in the conquest and exploration of the newly discovered territories, as well as benefiting from its wealth. The idea of the extraordinary richness of the New World, first associated with fabulous Asia, was later augmented by the results of the campaign of Hernán Cortés, the conqueror of the Aztec Empire (1519-1521). Despite the fact that only one other campaign, that of Francisco Pizarro, the conquistador of the Inca Empire (1532-1536), resulted in a similar booty, there were numerous attempts to pursue the legendary fabulous wealth of the new lands. Even later, when gold extraction declined giving way to silver mining, such as in the semi-mythical mines of Potosí in Peru, the colonizers continued to venture into Latin American territories, looking for the precious metal. The subsequent exploitation of the indigenous population, forced to work in mines, had a detrimental effect on the demographics of the mining regions. ${ }^{30}$

The methods of conquest and exploration were another factor that undermined the demographic stability of the indigenous population in Latin America. There are several causes that are historically considered to have had the most impact on the local 
population in the Colonies. Among them, there are the epidemics brought by the Spaniards (smallpox, measles, etc.), as well as the sociological and psychological shock from the drastic change in almost every aspect of pre-Colombian life (Aguirre Beltrán 27). These factors resulted in a weakening of the sociopolitical position of the indigenous population in Latin America, just as had happened to the conquered Moors during the Reconquest.

Mythmaking takes place only in fertile grounds, and the New World most definitely offered such grounds in every sense of the word (Memmi, Decolonization 19). On the one hand, the legendary wealth and opulence of Asia, and the unseen exuberant reality of the New World blended together in the imagination of the explorers and conquistadors, who often attributed magical powers to these lands and their inhabitants. ${ }^{31}$ On the other hand, Europeans came to the new continent with certain missions. First, there was an economic goal, as The Indies were believed to be a part of sumptuous Asia. However, the lack of immediate results led to the compensatory, religious agenda of the conquistadors, as can be seen, among other sources, in Christopher Columbus's Diaries..$^{32}$ As a result, mythmaking, which aimed to either legitimize one of these goals or to explain the absence of the expected results, took place already at the very beginning of the conquest of America. Hispanic Orientalism in its migration to the New World, thus, found a very fertile ground that allowed it not only to survive but also to adapt to the new reality.

One of the key factors that contributed to the smooth transition and fast "acclimatization" of the original paradigm of Hispanic Orientalism is the expansion of Christendom that became one of the driving forces behind the Conquest. There was a 
gradual transition between the end of the Reconquest in Spain, the "purity of blood" policies of its monarchs and the European arrival in the Americas. This process resulted in what Nicolás Alemán called "the re-conceptualization of the world" (234). It shook to the core not only the social and cultural establishment of the Old World, which resulted in the creation of a new social hierarchy in the Americas, but also affected the existing geographical knowledge about the world. This change became especially obvious after 1507 when the new cartographic design officially introduced the American continent to the Old World (O'Gorman 129).

Spaniards arriving in the New World brought with them not only their traditions and customs, but also their social and political views. Soon after the geopolitical division of the territories was established, the newcomers started adjusting the old Peninsular system of distribution of power to the new circumstances. For instance, the typical Spanish administrative division into municipios ("municipalities") in all its diverse forms was also adopted by the new authorities. Some rural communities with a predominance of indigenous population received a status similar to the Castilian municipio: the cacicazgo, where a cacique represented the authority. The presence of the two sociocultural groups often resulted in the appointment of corregidores ("mayors") of both European and indigenous origin (Tuñón de Lara 292-93). Despite this striking parallelism between the two systems, already during the sixteenth century the New World was gradually detaching itself from Spain. ${ }^{33}$ However, this process was slow enough to allow it to grow deep roots in the social system and the mentality of Latin America.

It is of no surprise then that the social structure in the New World during the preindependence period mirrored, in a way, the original Iberian social structure. The 
European-born noblemen, Peninsulares ("from the Iberian Peninsula"), were at the top of the hierarchy, governing the others and distributing the profits of their military and explorative enterprises. Naturally, they were Christian, and the conversion of the local population and the salvation of their souls, according to the common belief at the time, was one of their main duties. The other groups were very diverse in terms of ethnic background and religion, similar to medieval Iberia. But unlike Iberia, the novelty of the Colony arose from its new hybrid society where "almost everyone mixed with everyone else," a process accelerated by the fact that the Spaniards did not originally bring any European women (Orellana 85). This created a necessity to establish a more rigid hierarchical system defined by race (castas).

Several groups, whose role in history is significant, existed in the colony. First among them were the criollos, Europeans born and raised in the New World. Because of the latter, they occupied a lower position in the social hierarchy compared to those born in Spain. ${ }^{34}$ The figure of the criollo is crucial for understanding cultural and political processes in the New World, as they "were first at odds with the colonial Spanish administration and then with immigrants" (Civantos, Criollo viii). At the beginning of the nineteenth century, this dissonance resulted in the independence movement, led by the criollos who would assume the role previously played by the Peninsular colonizers. The mestizos, of mixed European and indigenous descent, were placed one step lower in the social ladder. They were, as Manuel Tuñón de Lara notes "producto de la gran libertad que reinaba en las Indias" ("a product of the great liberty that reigned in the Indies"; 293). Their European heritage and sometimes noble indigenous blood (like, for example, Inca Garcilaso de la Vega) allowed them to hold positions of relative power in colonial 
society. However, their relation to the indigenous population and their origin (often, out of wedlock) conditioned their social role.

Two other major groups, present in the New World, were the indios and the negros. The first represented the indigenous population, who practiced their religion, often clandestinely even after converting to Christianity, as was the case in Iberia with the converts. This situation gave rise to religious syncretism in Latin America: Christian saints were associated by the indigenous population with local deities, one of the most prominent examples being the Virgin Mary associated in Mexico with Tonantzin ("Mother Earth"). By the seventeenth century, the exploitation of the indios, as well as other factors, led to a dramatic decrease in their population, especially in certain regions like the Caribbean.

African slaves, who constituted the second marginalized group, were brought to the New World starting in the 1530s. By the seventeenth century their number had increased enough to play a significant social role in the Americas. Unlike the other groups, they were alienated from society, as their perception by other groups was derived from the fallacy that slavery was their "natural" condition. Even the fact that the Africans had a soul was subject to debate, and hence the dehumanization of the representatives of the Africans. In a sense, the methods and the outcome of their Orientalization was similar to that of the Jews in Medieval Iberia, who were similarly excluded from a society that alienated them and used their serviced only when they were needed.

The social and ethnic diversity in the New World immensely influenced not only the nature of the relationship among different groups, but also their economic and political status. Los blancos ("the Whites") atop the social ladder considered themselves 
hidalgos, noblemen, even though back in Europe, they did not necessarily possess this title. However, in Spanish Americas they reaffirmed their claim for nobility by avoiding any manual work, which was attributed to lower classes; however, they also demanded payment for their services. This self-identification was the origin of the encomienda, a feudal-type system of servitude in which the conquistador had the right of exploiting his subjects, the indigenous population. Despite several laws and royal decrees protecting the latter - prohibition of slavery of the indigenous population by the Catholic Kings in the Leyes de Burgos (1512-1513), reduction of the power of the encomenderos, the abolishment of Indian slavery and personal service and the institution of a native tribute by Charles V in Las leyes nuevas (1542) - the system of encomienda, officially abolished by 1720, continued to exist in some form in the Americas until 1791 (Tuñón de Lara 29394; Roa-de-la-Carrera, Infamy 231; Parry 7-11). However, for Hispanic Orientalism, the nature of this phenomenon is more important than its economic and social outcomes.

The encomienda was originally established during the period of the Reconquest of Spain and was meant to protect the inhabitants of the lands bordering with the Moorish kingdoms. In the Americas, this system was applied apparently to a considerably different situation - the indigenous population was perceived as unable to defend its rights and, therefore, in need of protection of the ruling class. However, this reasoning only perpetrated the image of the indio as el buen salvaje ("the noble savage") created in the contemporary chronicles and travelogues. Hence, it reinforced not only the further Orientalization of his image, but also served as another link between the New and the Old World, facilitating the migration of the original paradigm of Hispanic Orientalism to the New World. 
The present chapter examines the migration of the original paradigm of Hispanic Orientalism to Latin America and its development and changes in the New World during the Colonial period, when the Latin American continent takes its first steps towards economic and political independence. Such geographical and temporal span requires a solid literary corpus to be analyzed in order to trace the common changes in the original paradigm of Hispanic Orientalism. The authors of the memoirs and chronicles of the period represent a diverse social palette that is given special attention, as social factors played a crucial role in the process of Orientalization of the Other in Latin America, as they did in medieval and Renaissance Iberia. The texts analyzed in this chapter belong to authors of different social background and status. This approach allows establishing common aspects of Hispanic Orientalism in the early colonial period and distinguishing this phenomenon from that of the metropolis.

The first group of authors is constituted by the conquistadors and the explorers, whose vision of the newly discovered land is highly contaminated by the dominant discourse of power, as well as their personal goals and missions. While there is a large number of existing letters and travelogues left by the representatives of this group, special attention is given to the accounts by Christopher Columbus and Hernán Cortés because of their prominence and their impact on the popular imagery, as well as their influence on the other conquistadors and explorers.

The second group of texts are official and non-official chronicles. They are written from different perspectives: some from the hegemonic perspective of the metropolis, as in the case of Gonzalo Fernández de Oviedo or Francisco López de Gómara; and others from the perspective of the Other, such as the mestizo and 
indigenous chronicles. This work analyzes the process of Orientalization from the hegemonic perspective, so it is the chronicles written by the representatives of the dominant class that are in the center of the analysis. One the one hand, we look at the texts produced by Francisco López de Gómara, who brings a different perspective of the American Other, as he never visited the New World and did not have any first-hand experience of the narrated events. On the other hand, there are the unofficial chroniclers, such as Bernal Díaz del Castillo, who were very familiar with in the everyday life of the conquistadors and who themselves took part in the process of Conquest and exploration. His account of America differs significantly from Gómara's, whom he severely criticized for his idealization of the New World and the aggrandizement of the role of Hernán Cortés in the conquest of Mexico.

The third group consists of the testimonies of religious men, like Fray Julián Garcés, Juan de Torquemada, Diego Durán, Fray Joseph de Acosta, Diego de Landa, Fray Toribio Benavente (Motolinía), Bartolomé de Las Cases and others. These accounts, like that of Motolinía, whose texts are analyzed here, represent an attempt to view the Amerindian Other from a more "moral," Christian perspective; though they do not avoid the temptation of Orientalizing the Other for their own aims. Motolinía, along with other Franciscan friars, is one of the first authors to pay close attention to the moral and ethical situation of the aboriginal culture, using this knowledge to his advantage in his religious campaign. His ethnographic endeavor will later be followed by a more in-depth work by other friars like Fray Bernardino de Sahagún.

It is of great importance to point out that these authors had different goals when writing their narrations. While the conquistadors were seeking proof of their conquests 
that would improve their socioeconomic position, the chroniclers' were to attest to these events. The evangelists were immersed in their own religious campaigns, perceived as a continuation of the process of the Reconquest of Iberia and the earlier Crusades. They attempted to create a wholesome cosmogony of the New World. While some of the writings by their nature were to be less self-centered, they, nevertheless, exerted a mutual influence. The analysis of such a wide variety of the depictions of the new reality in America is crucial for the establishment of the Hispanic Orientalist paradigm in the new continent.

While the narrative of these authors was deeply rooted in the literary tradition of the Spanish kingdom and often transmitted a preconceived image of the Amerindian Other or an image defined by the Peninsular Orientalist approach, their ways of viewing and relating to the new Other were not the same. All the works analyzed here represent the point of view of the conqueror and, consequently, are in contrast with the texts by Mestizo chroniclers, such as Fernando de Alva Ixtlilxóchitl, Fernando Alvarado Tezozómoc, Diego Muñoz Camargo, and Juan Bautista de Pomar, and the indigenous chroniclers like Guaman Poma de Ayala, Tuti Cusi Yupanqui, and others. While the ways of self-representation and self-Orientalization by the subaltern culture are of undoubted interest, the present chapter is limited to the analysis of the dominant Orientalist paradigm based on the perception of the Other by the colonizer. It is this paradigm that was inherited and transported oversees with the first conquistadors and later evolved into the modernity.

The analysis of such a wide variety of chronicles and testimonies allows answering crucial questions that define the nature of Hispanic Orientalism in the New 
World. First, it establishes the reflection of the original paradigm of Orientalism in the texts created in/about Latin America; then, it reveals the differences between the original and the colonial paradigms of Hispanic Orientalism; third, it establishes the level of consistency of Orientalization among documentary texts created by the dominant social strata of the early colonial period; finally, it analyses the process of transformation of the "Oriental" into "Amerindian" and the authors' justification of this process. The answers to these questions contribute to the identification of Hispanic Orientalist strategies in the New World. Some degree of change in the original paradigm was inevitable, since Hispanic Orientalism, as demonstrated earlier, is intricately related to the discourse of powers and reflects sociopolitical changes in society. Hence, the migration, the establishment of a new society, and the new Latin American reality mirror themselves in the Orientalization techniques and approaches typically employed during the early colonial period.

\section{$\S$ 2. The Colonizers}

During the transatlantic migration of Hispanic Orientalism to colonial Latin America, the relationship between the hegemonic Spanish and the substrate cultures both in the Peninsula and in the colonized New World undergoes an unavoidable process of alteration. It is based, in part, on the essential sociocultural differences between the subaltern Others, the Moors and the Amerindians. It arises as well as a consequence of the newly established hierarchy and the resulting differences between the social strata of the dominant class in Spain and the American conquistadors. The relocation of the 
paradigm and the new geopolitical situation (as Spain became one of the largest empires in the world at that time), combined with the Islamic threat to Europe, were the major reasons for the changes in the original paradigm of Hispanic Orientalism.

The continuity and the relationship between the process of the Reconquest of Iberia and the Conquest of America are of great importance here. There are numerous historical and cultural links between these two events. Not only did they coincide historically, one ending and the other one beginning in 1492, but also geographically, as Columbus's enterprise received a royal approval in the former Al-Andaluz (Cummins 2). The new type of relationship, formed between the Spaniards and the Moors during the Reconquest, served as a future reference for all the encounters with the Other. It is a continuation of the Christian Crusades in search of the expansion of Catholicism and the European hegemony in the West (Taboada 45). The first literary depictions of the relationship between the conquistadors and discoverers and the Other, such as the accounts by Christopher Columbus, Hernán Cortes, Álvar Núñez Cabeza de Vaca, and many others prove the existence of the link between the Reconquest and the Conquest in the mentality of the people during that time. Such continuity not only casts light on the nature of Hispanic Orientalism in the New World but also unveils the raison d'être of its development.

Works like The Diary of Christopher Columbus (1492-1493, The First Voyage to The Indies) are especially important for tracing the transatlantic changes in the original Hispanic Orientalism and the understanding the process of formation of the new Latin American identity. The very first pages of the Diary illustrate the idea of continuity between the conquest of the so-believed Oriental lands by sea and the Christian 
Reconquest of Iberia. ${ }^{35}$ Columbus begins his account by mentioning the siege of Granada and the desire of the Catholic Monarchs, "amadores de la santa fe cristiana y acrecentadores de ella" and "enemigos de la secta de Mahoma y de todas idolatrías" ("lovers and promoters of the Holy Christian Faith" and "enemies of the false doctrine of Mahomet and of all idolatries"), to Christianize the land of Great Khan after "purification" of their own lands through the Reconquest and the expulsion of the Jews (Colón 15; Columbus 19). Hernán G. H. Taboada notes in this light that Columbus's perception of Islam is generally hostile (93). Religious fervor, along with the later Christian crusade in the Americas and the search for the Earthly Paradise in the Far East facilitated the adoption of the ideology from the Spanish Reconquest to the Conquest of the New World in the popular mind. These preoccupations of the conquistadors did not fall too far from the goals of the Reconquest: Christianization, ganancia ("profit") as the heavenly reward for being good and loyal Christians, and personal ascend on the social hierarchy.

Columbus's Diary is one of the first documents that show the results of the implementation of the Peninsular Orientalism after its transatlantic journey. It reveals the gradual transformations that occurred in the ways of perceiving the Other and rediscovering one's own self through it. There, the first traces of the new type of relationships with the Amerindian Other can be found. The difference in time and location, as well as in personal expectations of Columbus, and later on, of many other colonizers, evangelists and chroniclers are some of the factors that conditioned the beginning of the change in the traditional European Orientalism. These changes are 
significant, as they influenced the future interactions between the dominant social group and the subaltern cultures in the Americas.

There is no doubt that Columbus traveled to the West with a preconceived idea of the Other. He was significantly influenced by the readings of his predecessors about the mythic East, as well as the idea of Christianization that he mentions in the introduction to his Diary. During the first voyage, Columbus even had a converted Arabic-speaking Jewish interpreter for communication with the inhabitants of the land of the Great Khan, who presumably spoke Arabic (Cohen 12). As Flint notes, "Columbus's medieval readings also offered him manifold opportunities to ponder upon such associations and ... he seized upon these opportunities" ${ }^{36}$ (124). Peninsular Orientalism found a fertile ground in the imagination of Columbus and influenced his relationships and perception of the Amerindian Other, which, as many believed, was the same adversary Iberia and Europe had been facing for centuries. Having asserted the predominance of the Christian self over the Moorish Other, the nascent Spanish Kingdom expected to confirm its domain over the newly discovered America, considering her a part of the Orient.

In the Diary, the Orientalization of the Amerindian Other takes place on several levels. Each of them contributes to the perpetuation of a certain image of the new Other, el indio ("the Indian"), both in official historiography and in popular imagery. The first Orientalization strategy is related to the level of authenticity of the narration. The title of the memoirs states El primer viaje a Las Indias (The First Voyage to The Indies; Colón 15). Therefore, the text immediately suggests that Columbus is speaking for himself about his singular experience on the way to the legendary land of the Great Khan. At the same time, the text, as we know it, is a narration edited by Fray Bartolomé de Las 
Casas. ${ }^{37}$ Moreover, there is a recurrent use of formulaic expressions revealing Las Casas's desire to assert the authenticity of the text, like "Todas son palabras del Almrante" (“All are the Admiral's words"; Colón 31; Columbus 69; October 11, 1492). He even reinforces statements by personalizing the comments, such as "Yo vide algunos..." ("I saw some"; Colón 31; Columbus 67; October 11, 1492). Such polyphony is often confusing to the reader, who is struggling to separate both points of view and determine to what extent Las Casas uses Columbus's authority to advance his own agenda as an evangelist. ${ }^{38}$

What Las Casas achieves by the use of this technique is to establish certain credibility among his contemporaries. As a result, the type of relationship between the Spaniards and the Indians found in the Diary becomes paradigmatic. Without Columbus's authority, Las Casas was unlikely to establish such memorable and transmittable images. On the other hand, inferior to Columbus in social hierarchy, Las Casas had to go through the process of self-Orientalization in order to pretend to view the discovery through the eyes of his superior. This technique would become a typical discursive strategy for colonial and, later, independent Latin America, indicative of the desire for self-identification through opposition to the Other.

The second element that influenced the image of the Amerindian in the Diary, contributing to its Orientalization, is its idealization, which led to the reinvention of the New World's reality. This process was similar to that of Renaissance Iberia, where the Other gradually became the product of imagination rather than real history. However, the new reality that unfolded in front of Columbus and his men needed a new approach. The European literary tradition at the time included either chronicle-style narration or 
fairytale-like imaginary spaces that would culminate with chivalric novels, like Amadis de Gaula (1508). As the conventional chronicle-style narration could not properly convey the new reality, a more exciting approach was implemented: that of reinvention. It facilitated the comprehension and appropriation of the Other by the conquistadors, whose primary goal was to dominate the lands socially and culturally.

The appropriation of the Other through reinvention found its manifestation in Columbus's Diary on several levels. Most of the elements of the travel (its path, the newly discovered land and people, etc.) are surrounded by mystery. For instance, the existence of the path to the lands of Great Khan is an enigma, based on hearsay among the noblemen of the country, a tactic that can be seen in novela morisca like Guerras Civiles de Granada. ${ }^{39}$ After the expedition reached the promised lands, the Diary presents to the reader the fairytale-looking landscapes and the incredible fertility of the New World, which echoed the biblical description of Paradise: "la isla mas fermosa que yo vi ... vino el olor tan bueno y suave de flores o árboles de la tierra, que era la cosa más dulce del mundo" (sic) ("the island the most beautiful thing I have / seen ... the smell of flowers or trees that came from land / was so good and soft that it was the sweetest thing in / the world"; Colón 41-42; Columbus 99-101; October 19, 1492). However, the narrator would always keep in mind the mundane purpose of the expedition, the search for precious metals. The presence of gold, however, was important not only from the mercantile point of view. In Genesis we find: "There was also a river flowing out of Eden to water the garden, and from there it was divided and became four rivers. The first is named Pishon; it flows around all the land of Havilah, where there is gold, high quality gold; aromatic gum, too, and onyx stone" (The Holy Bible. The Berkley 
Version, Genesis 2.10-12). Therefore, the abundant presence of this precious metal was also an indication that the sailors might have reached the Earthly Paradise, which was believed to be located in the East.

Columbus's descriptions were also strongly influenced by the images taken from the texts of great travelers and historians of the past, like Marco Polo and Pliny, so it is of no surprise then that the newly discovered land was seen through the imaginative lens: exuberant, exotic plants and fantastic creatures, like men with dog heads and sirens supposedly inhabited this mysterious land. The reference to the dog is of significance. As Taboada notes, it is long rooted in the contraposition of Islam and Christianity, where canine references like "los omnipresentes 'perros' moros" could be the etimology of the words like "cannibal" and "Calibán"40 ("ubiquitous doggish Moors"; 95). There images influenced the travelers' perception of the Other and determined their interaction with it. The existing tradition of reinventing the Other was strong enough by the time of Columbus's travel to be transported overseas. Therefore, it is natural, that the Diary follows the path of reinvention to conquer the Other, the path that previously helped Europe to de-demonize the Moorish Other and include him in the social hierarchy of the nascent Spanish Kingdom.

The Peninsular Orientalist tradition was characterized by the Europeanization of the Other through portraying it as a debtor of Christian values and traditions and the follower of European ethics. The first step in this process was creating a distance between the two selves. Since the beginning of this encounter with the Amerindian Other, Columbus reinforced the gap between "us" and "them," constantly forming such oppositions in his text. The next step was the reimagination of the Other in order to 
include it in the social and cultural paradigm of the dominant society. As such, while describing the indigenous population of the New World, Columbus often referred to them as very susceptible to the Iberian culture and customs. Two weeks into his discovery of the new lands, he mentiones that "ya los entendían algo y mostraban estar contentos con los cristianos" (the English translation reveals even more directionality: "now the Indians understood the / Spaniards somewhat and appeared to be content with the Christians"; Colón 49; Columbus 121; October 29, 1492). This affirmation is followed by the description of the benevolence of Columbus who, as a good patron, prohibited ransacking the abandoned Indian village. Here, like in the case of the Renaissance Moors, the text portrays an Other reinvented by the dominant society. And, as in Iberia, the principles of nobility, la pureza de sangre and el cristiano viejo ("blood purity", "long-time Christian") are prominent characteristics of the hegemonic society that "discovers" and takes the Other under its "protection."

Not only do the traditional Iberian values find their repercussion in the ways of interacting with the Other, Columbus himself often refers specifically to the image of the Moor, of Andalusia, and its inhabitants and compares them to the New World. He uses both direct comparisons, as well as loanwords from Arabic: "hechas a manera de alfaneques" ("made in the fashion of very large Moorish campaign / tents"; Colón 49; Columbus 121; October 29, 1492) or "como en el Andalucía por abril y mayo" ("as in Andalusia in April and May"; Colón 48; Columbus 117; October 28, 1492). If the parallelism between the Moors and the Indians were not clear enough to the reader, the Diary explicitly compares the landscape of the Caribbean islands discovered by Columbus to the panorama of an Andalusian city with its minarets and other elements 
pertinent to Muslim culture: "una de ellas tiene encima otro montecillo a manera de una hermosa mezquita" ("one of them has / on top another little mountain like a pretty mosque"; Colón 50; Columbus 123; October 29, 1492). In case of Medieval Iberia, the hegemonic group was protected by God; in Columbus's account, it is God-like, as Amerindians "creían que éramos venidos del cielo" ("the believed that we had come / from the heavens"; Colón 45; Columbus 109; October 22, 1492). Coming from the Other, it is not perceived as Babel-like arrogance; on the contrary, it legitimizes the process of Orientalization. Similar tendencies can be seen in the novel Guerras Civiles de Granada, which emphasizes strong ties between the dominant culture and the Orientalized Other during the Reconquest and the Conquest of America.

The third factor influencing the perception of the Other and reinforcing its Orientalization are the goal of the expedition and the personal goals of Columbus. The initial desire to reach the legendary, opulent Orient was driven by the acquisition of gold. It is mentioned almost on every page of the Diary after the discovery. The Other, in this light, becomes only a guide, the means to reach the goal. Therefore, Columbus does not pay too much attention to the description of the nature of the interaction with the Amerindians at the very beginning of the Diary. However, when the expedition faced the scarcity of gold, its attention is driven back to the Indians. Under the pressure of the economic failure of the mission, Columbus returns to the idea of Christian salvation that was mentioned already at the beginning of his travel log. It is this moment that marks the beginning of the manipulations of the image of the Amerindian Other.

Like the Peninsular chroniclers of the period who depicted the relation with the Moors, Columbus selected a path of Orientalization through reinvention of the Other for 
the sake of its appropriation. Even though, it was hard for him to create a Europeanized image of the Indians, as it was done with the Moors, he most definitely tried to fit the Amerindians into the European Christian paradigm. The following and the similar comments reveal his manipulations: "No le conozco secta ninguna, y creo que muy presto se tornarían cristianos, porque ellos son de muy buen entender" ("I do not / detect in then any religion and I believe that they / would become Christians very quickly because they / are of very good understanding"; Colón 38; Columbus 89; October 16, 1492). Hence, the creation of "el mito de buen salvaje" ("the myth of the good savage") in the Diary is taked from the Peninsular Orientalist mechanism of reinvention of the Other through its portrayal as a part of a familiar paradigm. Once on that path, Columbus repeatedly refers to this technique to empasize the gentle character of the Indians, their child-like innocence and natural curiosity. ${ }^{41}$ Their nudity is constantly mentioned in the Diary, asserting the right of the Spaniards to subdue Other. The latter is gradually inserted into the paradigm of Spanish society where it soon plays an important but subsidiary role.

According to the text, the Amerindians seem to be kind and naïve, they are also very good looking, which for Columbus means God's approval of this nation and the possibility of its inclusion into the dominant sociocultural paradigm. ${ }^{42}$ Not only the external beauty but also the color is important, as it creates a parallelism with the Reconquest and the Moors: "ellos son de la color de los canaries, ni negros, ni blancos . . . Ellos todos a una mano son de buena estatura de grandeza y buenos gestos, bien hechos" ("They are of the color of the / Canarians, neither black nor white ... All of them / alike are of good-sized stature and carry / themselves well”; Colón 30-31; Columbus 67; October 11, 1492). 
Columbus goes even further by directly comparing the aboriginal population of the land and the population of Iberian Peninsula: "son blancos más que los otros, y que entre los otros vieron dos mujeres mozas tan blancas como podían ser en España" ("they / are whiter than the others, and that among them they / saw two young women as white as any in Spain"; Colón 88; Columbus 225; December 13, 1492). Such perception became popular to the point that "entre los primeros grabados sobre la llegada de Colón a la Española había uno, hecho en Alemania, que mostraba cómo de una galera (!) descendían a las islas del Caribe unos marinos con tocados moriscos" ("among the first engravings about the arrival of Columbus to Hispaniola, there was one, made in Germany, that depicted the descent from a galera (!) to the Caribbean islands of the sailors with Moresque-style headdresses"; Taboada 128). While the Moors of the literary text in Iberia knew the benefits of Christendom and considered converting, as did the protagonists of Abencerraje y la Hermosa Jarifa or Guerras Civiles de Granada, the inhabitants of the New World seemed to have forgotten Christianity and were following their pagan tradition. Columbus finds his proof of it in the supposed anthropophagy of the local population. As a result of this process of reinvention, he presented to the reader a prodigal son of the New World, ready and in need of being rescued. This Europeanized image facilitates the placements of the Amerindian Other into the hierarchical structure of the new Iberian society. ${ }^{43}$

Columbus's accounts of his first travel to the West had an immediate and profound impact on the mentality of his contemporaries not only in Iberia but in the whole of Europe. It can be seen, for instance, in the correspondence of the period, where the main Orientalist features of the New World are singled out. A perfect example of the 
impact of Columbus's Orientalism on the European mind is the letter from Aníbal Zennario to Jacobo Trotti, who later sent a copy of it to the Duque of Milan. In this letter, Zannario mentions, in particular, the following about the voyage and its results: "En XXXIII días arribó a una gran isla, en la que habitaban pueblos de color aceitunado y desnudos, sin ninguna máquina de guerra y muy temerosos," and later "con lo cual, perdiendo ellos el miedo y siendo hombres de rápida comprensión, colmaron sus deseos, pues por señas y otras maneras se enteraron a través de ellos que se hallaban en las islas de la India" ("In 33 days, they arrived to a big island inhabited by the people of olive color, naked, without any weapons and very timid"; "So they lost their fear and being smart people, they had their wished fulfilled, as by gestures and in other ways they understood from them that they were in the island of India"; Gil, and Varela 148; my emphasis). It is evident that not only the mythical destination of Columbus is being legitimized in this letter, but also the inhabitants of the land are reimagined offering Europe the ready-to-be-used myth of the noble savage.

Zennario falls for Columbus's Orientalism even further when he brings up the religious aspect. As he writes, Columbus "no ha percibido que observen entre ellos ninguna ley ni religión, sino que creen que todo proviene del cielo y que allí está el hacedor de todas las cosas; por este motivo espera que fácilmente se convertirán a la santa fe católica" ("did not see that they have any law or religion, but believe that everything comes from heaven and the creator of all things is there; because of that he thinks that they will convert easily to the Holy Catholic Faith"; Gil, and Varela 149; my emphasis). This passage almost paraphrases the very text of the Diary, which indicates the extent of the importance of the facts conveyed in this description. Not only is the 
Orientalized image of the Amerindians of interest for Zennario; he also transmits the synopsis of the Admiral's account about the fabulous-like newly discovered lands: "En dichas islas han encontrado, según dicen, pimienta, lignáloe y minas de oro por los ríos, esto es un río que tiene arenas con muchas arenillas de oro" ("In those islands, they found pepper, lingaloe, and golden mines along the river, meaning that the river has sand with a lot of golden grains"; Gil, and Varela 149; my emphasis). As a result, the image of the Americas, reinvented and appropriated in Columbus's writings, is immediately divulged across Europe through private correspondence and word of mouth. This facilitates the transmission of his Orientalist myths and their penetration into the popular mentality already familiar with the Europe's own Orientalist practices.

Other early chronicles and accounts about the New World were in no lesser degree influenced by Columbus's Diary and his Orientalization, as well as European Orientalist tradition. Another significant narration of the conquest of America, Cartas de relación (1519-1534) by Hernán Cortés, the conqueror of Mexico (1519-1521), echoes these main concepts of this relationship with the Other. In the history of the conquest of the New World there are two campaigns, the economic, the political, and the social consequences of which are difficult to overestimate. These are the expeditions of Francisco Pizarro, the conqueror of the Inca Empire (1532-1536) and the expedition of Hernán Cortés in the Aztec Empire. The campaign of Cortés, one of the first big successes of the conquistadors, in a way, sets an example for all the other explorers of the New World.

The idea of the continuation of the Reconquest in America is given a second life in Cartas de relación. The enterprise of Cortés was undoubtedly influenced by the 
voyages of Columbus. While the search for the mythical treasures was still a part of his expedition, another aspect of such campaigns also played a crucial role: the Christian quest to return the so-called "lost children" to their Christian faith (this aspect became more evident in the later Columbus's travel logs when his promises of attaining gold and condiments failed). At the same time, the debate about the legitimacy of the conquest arose at the beginning of the sixteenth century. The argument of Bartolomé de Las Casas and Juan Ginés de Sepúlveda about the morality and legality of the conquest culminated in the creation of the treatises by Dominican friar Matías de Paz and Juan López de Palacios Rubios (Carman 133). Although never published, they had a significant influence, as they established "an even more stringent guiding principle for Spanish colonialism: the king could not seek to extend his dominions or enrich himself"' (Roa-dela-Carrera, Ethics 180-91). Therefore, the Christian crusade in America became the only legitimate way for colonial expansion. It was impossible to complete this process without reimagining the aboriginal Other from the standpoint of the dominant culture. The previous Peninsular experience of the conquistadors facilitated this process. Cummins suggests that the Peninsular Orientalist tactics came into play "as soon as the conquistadors met, on the one hand, serious opposition, and, on the other, the astonishing creations of the builders and craftsmen of the mainland," as "for the real veteran among them, men hardened in their youth by the long campaigns of the Moorish wars, those marches through the hostile land of Mexico ... the curious tongues, the pagan temples and richly worked artifacts, the constant stress on their role as the vanguard of God, must have seemed very much an extension of the Christian Reconquest of Spain" (4). 
Therefore, is it of no surprise that Cortés refers to Moorish imagery and loanwords to portray the reality of the New World, much like Columbus. ${ }^{44} \mathrm{He}$ becomes a part of the tradition that not only established a direct connection between the Amerindians in the New World and the Muslims in the Iberia, but insisted on this relation even after the overseas territories began to play an important social and economic role in the life of the metropolis. The Orientalization of the Amerindian Other though its portrayal as a new Moor gradually became canonical in the Colony. Many other chronicles and codices used both the images and the loanwords to trace the similarities between these two Others. This technique was already used in Renaissance Iberia when portraying the Moorish Other, so its transition to America was easy and predictable. One such example is the inscriptions made by a Spanish scribe in the Codex Mendoza, a pictorial manuscript created by aboriginal artist, use Arabic words to describe Aztec religion, like alfaqui ("a Moorish priest") when referring to Aztec religious leaders, or mezquita ("mosque") when describing their temples ${ }^{45}$ (Cummins 207-08).

Another example is Nueva crónica y buen gobierno (fl.1613) of Felipe Guamán Poma de Ayala, where the defeat of the Inca army in the siege of Cuzco results from the miraculous interference of Santiago de Compostela, Santiago Matamoros (St. James of Compostela, the Moorslayer). ${ }^{46}$ Taboada mentions a significant transformation that happens to the image of the latter in America: "Fue Santiago, el campeón de la lucha antimora en la Edad Media española, que llevó a cabo hazañas transmarinas igualmente notables, apareciendo repetidas veces en los campos de batalla y auxiliando a los cristianos con un nuevo nombre: Santiago Mataindios" ("Santiago was the champion of the fight against the Moors in the Middle Ages, which resulted in his no less dramatic 
achievements overseas, where he appeared multiple times on the battle field helping the Christians under a new name: Santiago Indianslayer"; 193). Cortés himself refers constantly to the image of this saint (see letters 3 and 5, for example) when describing the military encounters with the Indians (Cortés, Cartas 154, 253). This continuity in the historical and literary practices in the Old and the New Worlds strengthens the thesis of the transatlantic continuity of the Hispanic Orientalist tradition. The hegemonic culture finds a place for the new "Moors" of America in society, but such incorporation is only possible if the Amerindians go through the process of reimagination and appropriation.

In Cortés's letters there are three recurrent topics that are important in relation to the Other: gold, God, and glory or the marvelous secrecy of the lands he explores and conquers. The three serve as a basis for his bidirectional Orientalization, that of the self and the Other. Like the chronicles of other conquistadors and explorers, the goal of Cartas de relación is to embellish the role of Cortés himself in the process of the conquest of Mexico and prove the righteousness of his deeds. Cortés presents himself as benevolent with the local population, convincing them that he will not do any harm and that his mission is peaceful (see Cortés, Cartas 23, 34, etc.). Contrary to his opponents, such as Diego Velázquez, he is an utmost loyal subject of the Spanish Crown, and he convinces the locals to become its vassals, duly noting every such request of the Amerindians (Cortés, Cartas 45, 53, 92, etc.). He is also a man of faith and has a messianic goal of converting the Indians to Catholicism (and making them vassals of the Spanish Crown at the same time). Throughout the Cartas, Cortés meticulously describes his religious fervor when he gives the Indians some religious objects, even destroys they idols in their temples in front of Moctezuma and his court, a clear comparison to biblical 
scenes. ${ }^{47}$ Carman calls this process self-mythification, as Cortés depicts himself as a victorious military and political leader who wins over both Indians and Spaniards (48). This self-Orientalization is possible because of the reinterpretation of his own deeds, as well as the Amerindian Other, both the land and its inhabitants. Unlike selfOrientalization of the post-Independence period, it does not serve the purpose of differentiation but rather self-embellishment.

Cortés's descriptions of the lands are indicative of the Orientalist path that his and the later narratives take. Unlike Columbus's Diary that has predominantly elated descriptions of the New World because of its novelty, Cortés's letters show ethnographic interest when the author engages in short but precise descriptions of local flora, fauna, and customs. However, the enchantment of America, so prominent is Columbus's writings, is not completely obsolete. In the Cartas, there is a recurrent set of adjectives and nouns describing the lands, the most prominent of which being maravilloso ("marvelous / wonderful") and secreto ("secret"). Often, these two words are used in the same context. Surprisingly, they refer not only to the perception of the conquistadors, but of the locals as well. For instance, Cortés talks about himself: "En este gran ciudad estuve ... sabiendo e inquiriendo muchos secretos de las tierras del señorío de este Mutezuma como de otras que con él confinaban y él tenía noticia; que son tantas y tan maravillosas, que son casi increíbles" ("While in this great city I was ... finding many of the secrets of Mutezuma's lands and those which bordered on them and those of which he had knowledge; and they are so many and so wonderful that they seem almost unbelievable"; Cortés, Cartas 68-69; Cortés, Letters 112-13). The conquistador culminates his account 
pronouncing solemnly: "es otro mundo sin duda" ("it is without doubt like another world"; Cortés, Cartas 96; Cortés, Letters 159).

The idea of the impossibility to fully comprehend the lands and their unusual life is recurrent in the Cartas; and Cortés accepts it as a natural fact, something that can be perceived as a part of magic realism of the New World. It becomes a motive for his adventures. More than once the conquistador insists that he cannot stop his mission before revealing the secrets of the lands in order to convey them to the Spanish kings. ${ }^{48}$ Cortés does not specify, what kind of secrets he is expecting to find, making it even more mysterious and intriguing. The reader, however, can speculate about their nature: perhaps, he refers to the mythical wealth? The word oro ("gold") is mentioned practically in every page of his letters. Cortés is very thorough when describing anything pertaining to this topic: in the first letter, there is a long list of golden objects sent to the kings; later, one of the conquistadors conveys in detail how much gold had each of the caciques he saw and how rich in gold was the land; Cortés even organizes an expedition to see the gold mines of the Indians.

Maybe, the secret of the lands are the religious practices of the locals and their tacit susceptibility to Christianity, as it was already insinuated by Columbus? While he considered himself an old Christian (“cristiano viejo"), Cortés draw a contrasting image of the locals. However, not too contrasting, so that he is able to carry his messianic goal of bringing Christianity to America. Along with the problem of the "gentes bárbaras" he offers a solution: "habiendo lenguas y personas que les hiciesen entender la verdad de la fe y el error en que están, muchos de ellos y aun todos, se apartarían muy brevemente de aquella errónea secta que tienen, y vendrían al verdadero conocimiento, porque viven 
más política y razonablemente que ninguna de las gentes que hasta hoy en estas partes se ha visto" ("barbarous people"; "had we interpreters and other people to explain to them the error of their ways and the nature of the True Faith, many of them, and perhaps even all, would soon renounce their false beliefs and come to the true knowledge of God; for they live in a more civilized and reasonable manner than any other people we have seen in these parts up to the present"; Cortés, Cartas 22; Cortés, Letters 36).

Such an attitude of the discoverers towards the aboriginal population is severely criticized by Bartolomé de Las Casas in his own chronicle Historia de las Indias (15271561). On the same note, Menéndez Pidal states: “Colón violó cien veces el derecho natural ... Cortés engaña al mundo diciendo que convirtió a los de Tabasco; ¿qué virtud tenía él para "con diez palabras mascadas y mal pronunciadas" conseguir que los indios rompieran sus ídolos, cesaran en sus sacrificios humanos y dieran vasallaje al Rey de España?" ("Columbus violated hundred times the natural law. . Cortés lies to the world when he says that he converted those of Tabasco. What qualities did he have in order to "with ten mumbled and mispronounced words" convince the Indians to break their idols, stop their human sacrifices, and pledge allegiance to the King of Spain?"; La lengua 10405). It is interesting, though, that the mentions of God in the Cartas are not equally distributed throughout the text, as are, for instance, the references to gold. They agglomerate around the descriptions of battles scenes or complicated cultural and political situations during the campaign. This reveals the true preoccupations of Cortés; however, it does not answer the question about the marvelous secrecy of the lands that the conquistador seeks to understand. 
In this light, the image of the indio becomes crucial to the understanding of America's mystery. Like Columbus, Cortés is interested in portraying the traditional indigenous population's lifestyle. He is much more realistic in his descriptions of the Amerindians and their behavior compared to his predecessors. He does not feel any remorse when characterizing the Amerindians as mean and cunning when they attack him instead of bringing promised food, or when calling them barbaric, their customs "horrible y abominable" ("horrid and abominable"), and their ornaments - "muy grandes y feas cosas" ("very large and ugly objects") that make them "muy deformes" ("a most deformed appearance"; Cortés, Cartas 21-22; Cortés, Letters $30-35) .{ }^{49}$ The use of the Indian and his culture during the colonial period, according to Stacie Widdifield, served to the colonizer, especially in Mexico, as an almost unlimited resource "to justify, if not reinvent, its own history and shore up structures of power and strategies of social control" (70, my emphasis). Thus, Cortés's Orientalism serves the purpose of legitimizing the colonial campaign of the hegemonic society. It is carried out from a more realistic perspective; nevertheless, it is still an artificial image.

The lifestyle and religious practices of the Indians described by the conquistador also point out to his Orientalist approach. In the first letter, Cortés establishes a direct link between the Moors and the Amerindians that he later exploits in his other letters. For instance, he describes the locals as Moorish-like not only in terms of their practices, in their estranged looks: "y los vestidos que traen es como de almaizales muy pintados ... y encima del cuerpo unas mantas muy delgadas y pintadas a manera de alquiceles moriscos" ("the clothes they wear are like large, highly colored yashmaks ... and on the top half of their bodies wear thin mantels which are decorated in a Moorish fashion"; 
Cortés, Cartas 21; Cortés, Letters 30). Their houses also bear startling resemblance to the Moorish houses in Southern Spain with their numerous patios inside the house and water wells. $^{50}$

But the most astounding association lies in their religious practices. The conquistador condones brutal sacrifices by the locals, comparing them tacitly to Islamic practices: women forbidden to go to the temple, religious men who never cut their hair, the Moorish-like decoration of the "mosques" with "zaquizamíes," a wood-decorated ceiling, typical of Moorish architecture (Cortés, Cartas 64). The perception of Islam as a sect, widespread at the time of discovery of America, also finds its echo in the writings of Cortés, who often refers to the local religion as "secta" (Cortés, Cartas 22, 64, etc.). Therefore, it becomes clear to Cortés's contemporary reader that the locals must abandon their repugnant customs and convert to Christianity for the sake of their salvation, of course with the help and enlightenment of Cortés.

Instead of comparing the local temples to the mosques ${ }^{51}$ ("mezquitas"), Cortés uses this word to directly reference them: "con éstos tienen sus mezquitas y adoratorios" ("Likewhise they have their shrines and temples"; Cortés, Cartas 21; Cortés, Letters 35). It is significant that in this contexts Cortés often does not refer to expressions, such as "like," which implies a comparison, but rather names the objects directly using an Arabic loanword, as one of the most popular Orientalization techniques of the period. ${ }^{52}$ As in the case of the land, here the conquistador also repeatedly recurs to the adjective "maravilloso," as when describing the Templo Mayor of Tenochtitlán. ${ }^{53}$ The comparison to the cathedral of Seville, which several times changed hands during the Reconquest serving at times as a mosque, is particularly characteristic of the Orientalized image of 
this battle ground for Christian conquistadors and the American "Moors," the Amerindians. This messianic role of Cortés is summarized at the end of the second letter: "los españoles habían tomado por fuerza la grande ciudad de Temixtitan, en la cual murieron más indios que en Jerusalén judíos en la destrucción que hizo Vespasiano" ("the Spaniards had taken by storm the great city of Temixtitan, in which there had died more Indians tan Jews in Jerusalem during the destruction of that city by Vespasian"; Cortés, Cartas 96; Cortés, Letters 159). This comparison reveals not only the continuous Orientalization of the New World, but also confirms the further alienation of the image of the Jews in the Peninsula.

The secrecy of the land at which the traveler marvels, the Muslim-like customs and religious practices of the Amerindians, whose good or bad, suspicious or friendly appearance described in the chronicles seems to depend on their attitude towards the conquistadors, and the self-mythification of the colonizers reveal the Orientalization path in the Cartas de relación. While there is an ethnographic interest on the part of Cortés, his America happens to be Orientalized as in the writing of his predecessors. Carman questions the very notion of truth in the Cartas: while the conquistador claims to defend it, his narrations "places the very notion of truth on slippery ground" (71). Cortés reinterprets the new reality and connects it to the familiar subjects in order to understand it better and for easier classification in the popular mind.

In sum, the accounts of the first conquerors of the New World have a significant impact on the popular Orientalized perception of America and its inhabitants. Based on the European Orientalist tradition at the time, as well as the experience of the Reconquest, Hispanic Orientalism was transported overseas and found a fertile ground 
for reimagination of the mythical New World. The Diary of Columbus reinforces his mission: the discovery of the new path to the legendary world of Asia and its attribution to the Spanish Crown. As a result, the encounter with the New World and its inhabitants undergoes a process of Orientalization, as this is the only way to claim the Spanish right to conquer and explore these lands. Columbus follows the long established tradition of reinvention of the Other in order to include it into the imagery of the Old World.

Even before the reader sees the very description of the Amerindians, he is already forced to follow the path of his predecessors, the Peninsular medieval and Renaissance audience, accustomed to the previously established Orientalist paradigm, based on Europeanization through reinvention and appropriation of the Other. Only such Other can be accepted by the dominant society. As a part of this social hierarchy, the new Other had to be taken care of, in other words, it had to be "civilized" and baptized. Such Orientalist strategy became very popular among the conquistadors of the Americas, who needed to find a plausible justification for their endeavors. In the Cartas de relación by Hernán Cortés similar mechanisms are used to legitimize the campaign and portray the local lands and their inhabitants. Cortés reinvents the reality of the New World using the same techniques of Peninsular Orientalism. While Cortés's account is not as imaginative as Columbus's, he also uses reinvention and sometimes reinterpretation of the Other. It shows a change in the original paradigm of Hispanic Orientalism that had previously gravitated towards the mythification. The reason for this shift is not only rooted in the transatlantic migration. As more and more information about the New World arrived in Spain through different sources, the path of reinvention was becoming increasingly 
difficult. Hence, it gradually gave way to the reinterpretation for the same purpose of appropriation of the Other and its inclusion into the existing social paradigm.

\section{§ 3. The Official and the Unofficial Chroniclers}

The first explorers and conquistadors of the New World composed their travelogues and letters to the Spanish Crown in order in order to create a written record of their achievements and "legalize" the acquisition of the conquered lands. However, the desire to improve one's own social and economic position often guided such writings, thus leading to misrepresentations and often exaggerations of the conquistador's role, as well as the fictionalization of America's reality. Unlike these personal writings, the chronicles, both official and unofficial, were written supposedly to bring a more neutral and independent account of the life and deeds of the newly acquired lands. Nevertheless, would such unbiased account be altogether possible?

Among the chronicles of the period, there were two distinctive types. Some of the chroniclers, like Bernal Díaz del Castillo, Gonzalo Fernández de Oviedo, Bartolomé de Las Casas, Francisco Cervantes de Salazar and others traveled to America and participated themselves in the events they later narrated. Others, like Francisco López de Gómara, never set foot in the new continent, heavily relying on the writings of the others. Such recycling of existing ideas was often severely criticized because of its lack of authenticity and inaccurate representations that closely followed the accounts of the very conquistadors, one of the major sources for these chroniclers, or were heavily influenced by their or the chronicler's political agenda. 
This section analyzes two, in a way, antagonical writings. One of them is Historia general de las Indias, the second part of which describes the conquest of Mexico (1552) by Francisco López de Gómara; its prohibition came several year later, possibly, because of its polemic description of the colonization process and the colonizers (Roa-de-laCarrera, Gómara 42). The other chronicle is Historia verdadera de la conquista de la Nueva España by Bernal Díaz del Castillo. Written between 1563 and 1568, almost thirty years after the author's participation in the campaign led by Hernán Cortés, it was long forgotten and published only in 1632. Historia verdadera, as an unofficial account of the conquest of Mexico, served as a counter argument to Gómara's Historia general de las Indias, an official account of the events. The selection of these two authors allows for comparing the mechanisms of Orientalization that these two types of chroniclers used, as well as comparing them to the discourse used by the conquistadors themselves, and Hernán Cortés in particular. Like in Cortés's Letters, the conquest of Mexico is at the center of our analysis of the texts since its impact was so significant for the newly established Amerindian Orientalism. It also allows for establishing parallels between the three accounts, the two chronicles and the Letters, in order to determine the changes in the Orientalist paradigm during the period of discovery and conquest.

The writings of the first explorers and chroniclers of the Indies aimed for a wider audience compared to the literature of the period, for instance, the chivalric novels with their intricate language of the "domadores de palabras" ("word tamers"); they were characterized by a simpler language that lacked Latinizing elements and were closer to the common spoken language, like the writings of Cabeza de Vaca or López de Gómara (Menéndez Pidal, La lengua 74-75). It allowed this new literature an easier way into the 
popular imagery. Gómara's Historia general de las Indias enjoyed a broad popularity to the point that it became the base of the chronicle written by an unidentified author in the Islamic world around 1580, the Tarih-I Hind-I garbi. Written in Turkish, translated into Arabic and Farsi, and reprinted in 1720, this chronicle represented a rather fantastic account of the American land and society (Taboada 111, 178).

The popularity of the work can be attributed to the fact that Francisco López de Gómara, an official chronicler of the Spanish Crown, takes advantage of the style of the chivalric novels and novela morisca, and also of the first chronicles and letters describing the discovery and the conquest. On the one hand, he creates an encyclopedic overview of the New World, its inhabitants and their customs, flora, fauna, and geography, covering the area from Chile and Peru to New Spain and Florida. On the other hand, he takes advantage of the familiarity with the Arab Other of his fellow citizens, often referring to it as a comparison and using elements of chivalric-style literature in his writings to reinforce such associations. ${ }^{54}$ His writing is educated and religious: in the first part he extensively cites the philosophers and historians of the past, as well as uses religion to exemplify and question the facts about the New World (López de Gómara, Primera parte 7-18). This combination allowed him to create an account that became immensely popular, which led to its almost simultaneous translation into multiple languages, therefore, increasing its impact on the popular minds all over Europe.

European Orientalist traditions are copiously reflected in Gómara's relationship with the Amerindian Other. It is not surprising, perhaps, considering the fact that the chronicler never went to America, so his interpretation of the new reality unavoidably had to use a familiar Spanish lens. As a result, his Orientalist approach to the New World 
heavily relies on its reinvention, the technique typical for the contemporary peninsular literature, for instance, to novela morisca. His ethnographic interests will culminate in the writings of his contemporary Fray Bernardino de Sahagún, whose Historia general de las cosas de Nueva España was a quintessential work of ethnographic thought of the period about Latin America. This curiosity, along with his religious views, though to a lesser degree, forced Gómara to find a new more interpretative approach to the perception of the Other than his predecessors. As a result, he relies more on the reinvention than on the traditional reinterpretation for the appropriation of the Other.

Gómara's Orientalism is based on several elements, whose cornerstone is religion, much like during the Reconquest. In the narration, he himself highlights the close connection between the Conquest of the New World and the Reconquest of Iberia, like "comenzaron las conquistas de indios acabada la de moros" ("the conquests of Indians began after the end of the Reconquest from the Moors"; López de Gómara, Primera parte 6). In this light, the evident nationalism of Gómara comes as no surprise. The Spaniards are the defenders of the true faith, and, for the chronicler, they deserve his praise as the dominant nation of Europe and the whole world. ${ }^{55}$

The chronicler reinforces this image throughout the text. It can be as obvious and come from other Spaniards, such as Gómara himself, as in chapter "Elogio de los españoles" ("Praise of Spaniards"; López de Gómara, Primera parte 384-85). Researchers, like Roa-de-la-Carrera, argue that "the Historia general engages in effective debate about the consequences of the conquest and makes no attempt to conceal its destruction" (Ethics 173) when in this chapter Gómara complaints that "el mal que hay en ello es haber hecho trabajar demasiado a los indios en minas, en la pesquería de perlas y 
en las cargas" ("The evil in it is to force the Indians to work too much in the mines, as pearl fishers and load carriers"; López de Gómara, Primera parte 385). While it is partly true, and the chronicler does reveal the consequences of the often brutal conquest, he hides them immediately behind religious reasons, in the same way the "cristianos malos" were the ones to blame for their cruelty towards their enemy in Guerras civiles de Granada, as "Dios ha castigado sus gravísimos pecados por aquella vía" ("God punished their great sins in this way"; López de Gómara, Primera parte 385). An indirect praise of the Spaniards can be found in the descriptions of the explorers and the conquistadors; it even comes from the Indians who believe them to be gods. However, while the compatriots enjoy author's admiration, the others, both the locals and the Europeans, are portrayed as noticeably inferior. It is especially obvious in the comparison of the figures of the praised Cortés ${ }^{56}$ and the lucky Columbus, whose discovery the chronicler attributes to a Spanish sailor, whose maps Columbus retains after the death of the latter. ${ }^{57}$

America and its inhabitants are key figures in Gómara's theorizing of Spanish nationalism. Like Cortés, he often marvels about the land and the events he is describing. ${ }^{58} \mathrm{He}$ uses the same word maravilla / maravillar ("marvelous / to marvel") in similar circumstances, which indicates his intent to reimagine the reality that is so different to the one he knows. At the same time, another recurrent word, gran (grande / grandeza / grandísimo) ("great / big / greatness, enormity / the greatest, the biggest") appears in his writings. ${ }^{59}$ The vagueness of its meaning, as something imprecise but the one that causes admiration, can be indicative of the limitations of Gómara's imagination and his impossibility to verbally convey the impact of the reality he never saw. 
The use of the superlative suffix "isimo," ${ }^{60}$ prominent in Historia general, also might point out to the very same fact, inviting the reader to imagine rather than understand why the Indians were not only "muy putos" but "falsísimos," "ingratísimos," and "inimicísimos," or why the Spaniards were not just lucky but "dichosísimos," and not just religious but "devotísimos" and "religiosísimos" ("great lechers"; "the falsest"; "the most ungrateful"; "the most hostile"; López de Gómara, Primera parte 128, 204, 373; "the luckiest"; "the most devoted"; "the most religious"; López de Gómara, Segunda parte $429,162,404)$. Despite relying heavily on imagination of the reader, Gómara does show intent to interpret the new reality rather than reinvent it. He introduces local words in his writings. In the second part he even tries to describe them or give a Spanish equivalent (compared to the simple use of the local words in the first part) in an attempt to approach the reality: "teucalis" - "templos," "tianquitzli" - "mercado" ("temple"; “market”; López de Gómara, Segunda parte 59-60, 151).

He also uses the words describing Catholic religious practices in order to portray the Indian religious practices and ritual places: "una torrecilla maciza con una especie de capilla en lo alto" or "una especie de sacristía" ("a massive tower with some kind of chapel on the top"; "a type of sacristy"; López de Gómara, Segunda parte 62, 34). Not only religion, but also life in the New World is often portrayed through European images: "gran ejército de aquellos indios," "mayordomo" and "lacayo" of Moctezuma, his "escudo de armas" and "banderas," or "romance viejo" that the Indians sang as a prayer ("great army of those Indians"; "butler"; "lackey"; "coat of arms"; "flags"; "old romance"; López de Gómara, Segunda parte 78, 134, 52). While the use of these terms is similar to the use of Arabisms by Cortés in the sense that both of them reimagine the 
current reality, it is yet a step forward, as here, the starting point is not the externalized Other, but an internalized self. This contributes to a more rapid and successful appropriation of the Other through the process of reinterpretation.

Gómara's nationalism allows him to occupy a hegemonic position in the dialogue with the New World, enabling him to be the sole source of judgment about its value and qualities, which facilitated the Orientalization of the Other in his Historia general. After having established Spain's authority, Gómara then reimagined the New World, recreating its image as parallel to that of the Peninsula. As a skillful writer, he uses both linguistic and extra-linguistic tools to achieve his goal. The "Arabization" of Amerindians by his predecessors proved to play a pivotal role in the process of justification of the conquest of America. Gómara uses many of these traditional tactics to legitimize the right of Spaniards to engage in the new overseas crusade. Like Colúmbus, he often uses words of Arabic origin, especially in the descriptions of Amerindians and their life. These are both the words that were widely used during his time as "algodón" or "aceite," and other less common words ("cotton"; "oil”; López de Gómara, Segunda parte 18, 23). However, there is a tendency to agglomerate such words in the descriptions of the Indians and their way of life. ${ }^{61}$ Gómara reinforces this image by calling them "infieles" ("infidels"), and this adjective usually follows the mention of the Iberian Reconquest, which gives it an even deeper meaning, highlighting Gómara's messianic view of the Spanish nation: "al acabarse la conquista de los moros . . . comenzó la de los indios, para que siempre peleasen los españoles con infieles y enemigos de la santa fe" ("after the end of the conquest of the Moors, the one of the Indians started, so that the Spaniards were always 
fighting the infidels and the enemies of the Holy Faith"; López de Gómara, Primera parte 33).

The text of the chronicle abounds both in tacit and explicit comparisons to the Arab world, its traditions and customs. The rivers of the New Worlds are compared to the Nile (López de Gómara, Primera parte 153). The appearance of the Indians is also exotic and Oriental: they have "zarzillos en las orejas, anillos en las narices, and "they are dressed "en mantas" ("earrings in their ears and rings in their noses"; "blanquets"; López de Gómara, Primera parte 122). Their family and marital traditions seem to be taken directly from the Arab world. ${ }^{62}$ Ultimately, Amerindian lifestyle is Arab-like: they are nomadic; they embalm their diseased and follow other "Oriental" practices. ${ }^{63}$ Even their priests "borrachos o encalabrinados con humo" can be regarded as an allusion to the "drunken Sufism" founded by Persian Sufist Tayfur Abu Yazid al-Bustam polularly known as Bayazid al-Bistami in the ninth century (“drunk or altered with fumes"; López de Gómara, Primera parte 122). This parallel is reinforced by the comparisons of the ritual dances to "la zambra de los moros" ("the zambra celebration of the Moors"; López de Gómara, Primera parte 53).

Taking into consideration these tacit and open Orientalist claims by Gómara, it is then logical that in the second part of the chronicle it is Santiago Matamoros, and not the Apostle Peter who appears on the battle field to protect the Spaniards, because the local population had to be first defeated and reverted from their "sodomía" ("sodomy") before they can earn their way into Heaven. ${ }^{64}$ As in the other texts, the biblical references ${ }^{65}$ here serve the chronicler's agenda and are skillfully used as the underlining argument to prove Gómara's legitimizing theory of the conquest. It is also curious that while proclaiming 
that "la conquista de Méjico y conversión de los de la Nueva España, justamente se puede y debe poner entre las historias del mundo," in his brief overview of these glorious stories Gómara suggests that "no deberíamos meter en esta cuenta a los reyes de los judíos" ("the conquest of Mexico and the conversion of those of New Spain can be and should be justly included into world history"; "we should not include the Jewish kings into this account"; López de Gómara, Segunda parte 8, 7). This asseveration follows the alienating tendency of Hispanic Peninsular Orientalism towards the Jews, and, therefore, once again confirms a close link between Gómara's Orientalist practices and the original paradigm formed during the period of the Reconquest.

While, on one side, Gómara insists on the similarities of the conquest of America and the Amerindians and the Reconquest of Iberia and the Muslims, he nevertheless, draws an important line between them. It is necessary in order to legitimize the conquest and the religious crusade in America. He adopts Columbus's approach to the Amerindians as noble savages. Their nudity is constantly noted by Gómara on the pages of the chronicle (see, for example, López de Gómara, Primera parte 69, 76, 77, 113, 141, 162; López de Gómara, Segunda parte 33). They are also often portrayed as "hombres simples," "gente pobre, pero caritativa y muy religiosa en aquella su falsa creencia" ("simple men"; "poor but charitable people, and very devoted to their false religion"; López de Gómara, Segunda parte 34). Their religious devotion is important, because, when converted, they were perceived to become devoted Catholics. But the Amerindians, according to Gómara, not only possess a religious predisposition, they also have the knowledge of the Spanish hegemonic societal structure, based on the concepts of nobility and honor and honra, which is indicative of their easy integration into the colonizer's 
society. When Moctezuma invites Cortés and his men, he asks the conquistador about their social status in order to treat them accordingly. ${ }^{66}$ This will later evolve into the system of casts, copiously depicted in the so-called castas paintings that became another source of Orientalization in the colony in the eighteenth century.

The ultimate goal of such manipulations of the image of the Indians was to prove that they were a lost Christian tribe, which would serve as the decisive justification of the conquest, since the religious route was proclaimed the only legitimate way of exploration of the New World. Orientalization through reinvention of the Amerindian population from the perspective of the Spanish hegemonic society presented a convenient mechanism to carry out these manipulations. They allowed Gómara to evolve and reinforce the idea of the linkage between the Old and the New Spain. At the beginning of the first part, he only introduces this concept, although he does not appear to be entirely convinced himself: "allí se hallaron cruces de latón y palos sobre los muertos, de donde arguyen algunos que muchos españoles se fueron a esta tierra cuando la destrucción de España hecha por los moros en tiempos del rey don Rodrigo" ("There they found brass crosses and sticks over the tombs, and because of that some argue that many Spaniards went to this land when Spain was destroyed by the Moors during the reign of king Rodrigo"; López de Gómara, Primera parte 86). In the second part, when the reader is already familiar with the Orientalized image of the Amerindian Other, it is Moctezuma himself who attests to the chronicler's theory:

Recuerdo debéis tener . . . cómo ni somos naturales de esta tierra, ni nuestro reino es duradero; porque nuestros antepasados vinieron de lejanas tierras, y su rey o caudillo que traían se volvió a su tierra, diciendo que 
enviaría quien los rigiese y mandara si él no viniese. Creed por cierto que el rey que esperarnos hace tantos años, es el que ahora envía estos españoles que aquí veis, pues dicen que somos parientes, y tienen desde hace mucho tiempo noticia de nosotros.... Me haréis placer que os deis .. . por vasallos del Emperador y rey de España, nuestro señor, pues yo ya me he dado por su servidor y amigo. (López de Gómara, Segunda parte 173-74)

You should remember that we are not from these lands and that our kingdom is not long-lived, because our predecessors came from far away, and their king or caudillo returned to his land promising to send someone to reign and command them if he did not come back. Be assured that the king we have been waiting for so many years is the one who is now sending the Spaniards you see here, as they say that we are related and they have learned about us long ago. You will please me if you proclaim yourselves the vassals of the Emperor and king of Spain, our lord, as I did when I offered him my service and friendship.

Here, Gómara skillfully uses actual beliefs and historical events, although reinterpreting them to fit his goals. This becomes the quintessential justification for the inevitability of the conquest of America, whose reinvented self seems to be nothing else but the mirror image of the colonizer. In this case, the conquistadors in their pursuit not only look for humane retribution, but are guided by God, since the conversion of these so-called lost Spaniards becomes their sacred duty. That is why in the chronicle, the 
vassalage, the religion and the success, military or financial, go hand in hand, reinforcing the idea of divine support of the Conquest. And, as in the Cid, the treasures, obtained by Cortés and his men, seem to be the divine reward for their actions. The acquisition of gold, silver, pearls, and precious stones is meticulously documented by Gómara and serves as testimony of the divine approval of the conquest. ${ }^{67}$

However, in order to justify the methods and cruelty of the military campaign, it was not enough to compare and contrast the image of the Amerindians to that of the Moors. It needed to be further Orientalized in order to convince the reader that the only approach to rescuing these lost people was military conquest. As a result, Gómara creates a fantastic image of the Indians, attributing to them all possible negative characteristics. Most of the local population is depicted as a group that shares similar traits, regardless of the region where they live: This "gente tan inhumana y bárbara" not only displays negative personal characteristics, they are so "asnos" that Gómara even curses at them ("people so inhumane and barbaric"; "gross"; López de Gómara, Segunda parte 32). And what is even worse, they sacrifice and even eat other human beings, a recurrent image in Historia general (see, for instance, López de Gómara, Segunda parte 136). They are Sodomites and idolaters, and even their land smells like sulfur, a clear allusion to the infernal chaos (López de Gómara, Primera parte 372, 360). If this was not enough to cause consternation among his readers, who would approve of Christian salvation of such tribes that warded off the path of civilization, Gómara offers an even more repugnant summary that he attributes to a renown religious man and the confessor of the Emperor Fray García de Loaisa. ${ }^{68}$ 
Gómara is horrified by the customs and the religious practices of the New World. By creating a macabre picture of Amerindian religion, he urges their conquest and Christianization, which he sees as a blessing. Gómara openly and repeatedly states that the Amerindians are possessed by the devil, which, on the one hand, is negative, as it denounces them as sinners; but, on the other hand, it is a desirable condition, because it inserts the Amerindians into the Christian dichotomy of good and evil. It means that they can be rescued by the conquistadors. After all, despite their paganism, they once knew the true faith, the confirmation of which one can see, for example, in the fact that "bien pensaban estos mejicanos que las almas eran inmortales" ("and those Mexicans believed strongly that the soul was immortal"; López de Gómara, Segunda parte 393). It is not a coincidence that after the conquest, Gómara creates a positive image of the locals, who overthrow idols and do not see the devil any more, and the narration of their lives culminates with the chapter "Lo bien que libraron los indios con ser conquistados" ("The benefits of the freed Indians after their conquest"; López de Gómara, Segunda parte 434).

That is why, in Historia general, unlike in Bernal Díaz's chronicle, the conversion of the Indians is not only in the center of the author's attention, it is also a one way process, where the Indians are portrayed as eager, readily accepting the lost children of Christianity. Gómara's long discourses about the benefits of the conquest and the sermons of Cortés, like the one in Tenochtitlán on the negative consequences of idolatry, are a brilliant example of, using Carman's term, "Renaissance ventriloquism," which allows the author to inadvertently defend the conquest of America in the eyes of not only his European readers, but in the eyes of the colonized society (Carman 133-34). The religion and the supposed common past serve here as an egalitarian principle that allows 
to form the bridge between the colonizer and the colonized through Orientalization of the latter.

Because of this reason, the idyllic scenes ignore sometimes the reality of the conquest, as Gómara does not retain readers' attention on the cases of the renegades, like Gonzalo Guerrero or the baptized Indians who abandon their Christian faith. All of this also can explain the very limited attention that the chronicler pays to the Indian interpreters of Cortés: Melchor is called "rudo y simple," while Doña Marina, whose original name is not revealed by Gómara, is barely mentioned ${ }^{69}$ (López de Gómara, Segunda parte 28). As Carman notes, "as soon as she appears in the narrative, she is translated, baptized, and given Castilian identity" (121). At the same time, Jerónimo de Aguilar is focused on as a symbol of the coming religious redemption of the Amerindians. Gómara, once again, resorts here to his nationalism. When Aguilar is rescued by the Spaniards, the first thing he asks about is if they were Christians, and as they confirm, Aguilar "les rogó que diesen gracias a Dios . . por la merced que le hacía de sacerlo de entre infieles y hombres infernales, y ponerle entre cristianos y hombres de su nación" ("he begged them to praise the Lord for his favor, as he took him from the infidels and infernal nation and put him with Christians and his countrymen"; López de Gómara, Segunda parte 30-31). Gómara seems to believe that the Christian conquest brought positive changes to Amerindian society despite its atrocity, especially in light of new regulations that came into existence in 1542 that proclaimed the elimination of Indian slavery, as well as forced service, both domestic or as carriers, and assigned them to pay a tribute instead (Roa-de-la-Carrera, Ethics 231). 
As a result of Gómara's manipulations with the Latin American Other, the reader is presented with its Orientalized image that is a logical continuation of the Orientalization practices found both in the Peninsular literature and in the accounts of the first discoverers and colonizers. The author reimagines the Indian in order to legitimize the conquest, taking advantage of the work already done by his predecessors. However, his ethnographic interests also allow him to use a more interpretative Orientalism, which will find its manifestation in later writings, like the another chronicle depicting the conquest of Mexico, Historia verdadera de la conquista de la Nueva España by Bernal Díaz del Castillo.

Created in response to Gómara's account and unlike the letters of Cortés, it was written long after the end of the campaign. This allowed the author to distance himself from the events, as well as travel through time and space: often, he emphasizes the importance of an event by comparing it to the future ones, like the conquest of Peru. It makes his account more verdadero (veridical), which was, after all, the goal of Bernal Díaz. ${ }^{70}$ However, Gómara's account undeniably influenced Bernal, to the point that some argue for systematic plagiarism of his chronicle by Bernal Díaz (Roa-de-la-Carrera, Gómara 35; Iglesia 77-96). ${ }^{71}$

To his credit, Bernal Díaz tried to clarify all the possible contradictions between his account and that of the others. For instance, it is in his Historia verdadera where we find the mention of Cortés's lost letter. His first letter was never found or published; Bernal Díaz mentions this missing letter very vaguely in his chronicle: "Cortés escribió por sí, según el nos dijo, con recta relación; más no vimos su carta" ("Cortés wrote, as he told us, his own true account, but we never saw his letter"; Díaz del Castillo, Historia 
135). Henry Wagner also proposes that Gómara had a copy of the original, which he used for his own chronicle (155).

Gómara is severally criticized by Bernal Díaz for his exaggerations in terms of almost everything, beginning with the heroic role of Cortés in his conquest and ending with the descriptions of the New World. Bernal finds himself obliged to correct Gómara almost on every other page with the exception of the narration about the conquest of Tenonctitlán, where he seems to be carried away by the events. ${ }^{72}$ Unlike Gómara, Bernal is not fixated on numbers and distances, but tries to create an epic account of the conquest of Mexico from the point of view of the soldier, who is unfortunately forgotten in the official chronicles. He often uses the collective "we" to give the voice to those soldiers, including himself: “¡Oh qué cosa tan trabajosa es ir a descubrir las tierras nuevas, y de la manera que nosotros nos aventuramos!” (“Oh, how difficult it is to go and discover new lands, especially in the way we ventured"; Díaz del Castillo, Historia 14; my emphasis). Understanding this approach is crucial for the interpretation of Bernal Díaz's perception of the Other. His different standpoint and goals for his narration result in a significant shift in Amerindian Orientalism from the first chronicles.

In order to explore Bernal Díaz's version of Orientalism, his descriptions should be compared to the key Orientalized elements of Cortés himself: gold, God and glory. It soon becomes obvious in Historia verdadera that the gold rush is not the author's primary focus. While in Cartas de relación the search for gold is the main goal, and even Christianization seems at times secondary, Bernal Díaz's chronicle often just attests to the presence or absence of the precious metal. It does not become an object of fixation for the soldiers; though, they welcome its abundance. The attention of Bernal Díaz is on the 
story itself and on the heroic deeds of the simple soldiers. The concepts of el honor y la honra becomes predominant in the chronicle and is applied to both the Spaniards and the Indians as a universal concept. ${ }^{73}$ As a result, gold is not the primary reason for Orientalization in Bernal Díaz's account.

Another object Orientalized by Cortés is the land and its inhabitants, and here lies the most substantial difference between both authors. While the novelty and the desire of self-Orientalization for the purpose of personal prosperity lead Cortés to marvel at the New World and its inhabitants, the time gap and a more veridical approach of Bernal Díaz allows him to create a more realistic picture. Unlike Cortés, he often invites the reader NOT to marvel at the otherness of the New World. His linguistic choices here are important. He uses the word "marvelous" ( maravilloso $^{74}$ ) only later in the account (in Cartas it is much more recurrent). Instead of this word, that triggers the imagination or reimagination of the subject, he uses the adjective gran or grande ("great, large, major, big"). While, as in case of Gómara, it can be indicative of intent to convey extraordinary nature of the New World, Bernal almost never uses it in the superlative form, unlike Gómara. This implies a statement of a fact rather than a comparison. Hence, an interpretation rather than creation of a relatively abstract matter is what triggers readers' imagination: "gran carga de oro" or "muy grandes ofrecimientos que Cortés les hizo;" "gran Montezuma," "gran fortaleza de México" or "gran poder del emperador" ("big load of gold"; "great offerings of Cortés"; "great Moctezuma"; "great fortress of Mexico"; "great power of the emperor"; Díaz del Castillo, Historia 101, 134, 97, 154, 281). Yet again, the author uses this word indiscriminately in the descriptions of both the Spaniards and the Indians. 
The image of the latter in Bernal Díaz's chronicle is also rather different. While Cortés's Orientalization causes him to reimagine the looks and the behavior of the Indians, the author of the Historia verdadera seems to marvel at neither their ritual deformities nor exotic looks. Rather, he creates a linguistic entourage that helps the reader to easily identify the characters. There are several words that are constantly used when the Indians, both guerreros ("warriors") or naturales ("aboriginal"), are mentioned: canoa, flecha, algodón ("arrow," "canoe," "cotton"; Díaz del Castillo, Historia 75, 81; $75,77 ; 57,81)$. These words are used on the same pages and in the same context, thus, forming part of a semantic entourage of the Amerindians. In the same way the word caballo ("horse") is used when talking about the Spaniards (Díaz del Castillo, Historia 57-58). It is curious that a bridge-word between the two antagonists is gallina ("chicken") that often changes hands and serves as a precious commodity for both groups (Díaz del Castillo, Historia 61, 67, 84, 90, 94, 97, 180). Bernal also does not avoid direct, sometimes inferior descriptions of the Indians, as their lengua ("interpreter") Melchor, an Indian convert, whom he does not trust and describes as perfidious (Díaz de Castillo, Historia 78).

It seems that the figure of the Amerindian in Bernal does not go through exactly the same process of reinvention as compared to the accounts of Columbus or Cortés. However, it would be erroneous to say that he avoided Orientalization of the Other. The very inferiority that Bernal Díaz attributes to them arises from it and will lead to the formation of the famous system of casts that becomes so popular in Mexico in the eighteenth century. When the chronicler describes the Indians as "locos" ("crazy") (164) or "muy hermosa para india" ("too beautiful to be an Indian"; Díaz del Castillo, Historia 
$164,133)$, he reveals his hegemonic approach that is now disguised in a "verdadera historia" of the conquest. However, the basis of this Orientalism is gradually changing from that of the first colonizers. While Columbus and Cortés rely heavily on reimagination and reinvention of the reality of the New World, Bernal Díaz some thirty years after the conquest of Mexico chooses reinterpretation, which becomes a more efficient way for the appropriation of the Amerindian Other at his time.

Another proof of this change in the Orientalist strategies can be found, again, in the linguistics preferences of Bernal Díaz. While the first accounts used Arabic loanword to describe the new reality, most of the Arabisms in the Historia verdadera are used in neutral contexts ${ }^{75}$ for routine descriptions (with only a couple of exceptions, which will be mentioned later). ${ }^{76}$ It indicates, on one hand, that these loanwords gradually became an integral part of Spanish language, and, on the other hand, that Arabisms were no longer indispensable for the process of Orientalization of the Amerindian Other. At the same time, the words originated in the native languages of the region are much more abundant in the chronicle. Often, Bernal Díaz introduces them in pairs, a Spanish and a local word, unfamiliar at the time, for an easier understanding: cazabe - yuca ("yucca"), estera petate ("mat"), gran señor - lopelucio ("great master/lord"), ídolos - teules ("idols"), navios - acales ("ships") (Díaz del Castillo, Historia 19, 30, 104, 119, 192, 201). He makes sure that while his account is as authentic as he would like it to be, it is also clear and understandable, and even educative for the reader. He clarifies not only the words, but also cultural refeences, for example, when he mentions that Moctezuma decides "hacer ciertos sacrificios en recompensa del gran tlatlacol, que quiere decir pecado ("to make certain sacrifices to compensate the great tlatlacol, which means sin"; Díaz del 
Castillo, Historia 261). Curiously, most of these words are now officially part of Spanish dictionary, similarly to the Arabisms, used by the chronicler, that were gradually becoming a part of his contemporary language.

The reinterpretation of reality is also prominent in the comparisons that Bernal Díaz uses in this chronicle. While his predecessors had a tendency to compare the reality of the New World to that of Southern Spain, to cities, like Granada, Seville or Cordoba, all belonging to Al-Andaluz, and heavily influenced by the Moors (for example, see Cortés, Cartas 62-64), the author of Historia verdadera chooses a much wider range of cities and localities of Spain for his comparisons: the geographical position and the city profile of Valladolid with its towers, the picturesque landscape of Talavera and Palencia, the abundance and the fairs of Medina del Campo, his homeland, the plaza mayor of Salamanca, slaughterhouses in Castile, etc. (Díaz del Castillo, Historia 207, 224, 256, $258,260)$. The very reality of the New World is often expressed in terms of his contemporary Europe, which indicates the transatlantic rebirth of the Europeanizing tradition present in Renaissance Iberia. For instance, in his descriptions, he uses culturally oxymoronic word combinations such as "escuadrones de indios," "guarniciones de mexicanos," "mayordomo de Montezuma" ("squadrons of Indians"; "Mexican garrisons"; "Moctezuma's butler"; Díaz del Castillo, Historia 79, 123, 249). It would be difficult to imagine Bernal's predecessors using similar terms on such a regular basis. The above mentioned expressions are based on physical resemblance of the two objects rather than on the reinvention of one of them by attributing to it the characteristics of the other. All of the above shows the ethnographic interest of Bernal Díaz and advocates for an interpretative Orientalization of the Amerindian Other rather than a mere reinvention. 
While the gold and the peculiarities of the lands and its inhabitants play a secondary role in Historia verdadera, the third crucial topic, the religion, is very prominent. Unlike in the previously analyzed accounts, the mentions of God are quite constant here. Not only does Bernal Díaz refer to God, Jesus Christ and the Virgin Mary when he needs their heavenly patronage, it becomes a recurrent motif in his writing. When describing religion, he becomes a traditionalist. The scenes of the Spaniards overthrowing the pagan idols of the Amerindians and forbidding the locals to perform their ritual sacrifices, as well as the conversion to Christianity of Indian men and women are abundant in the narration, especially during the march on Tenochtitlán (see, for example, Díaz del Castillo, Historia 43 and 233). However, it is the religious aspect of the Historia verdadera that reveals the gradual change in Hispanic Orientalism from reinvention to reinterpretation, since some of the aspects in Bernal's account remain very similar to his predecessors, and others show a change that was already seen previously.

Unlike the earlier accounts, Historia verdadera makes a very direct connection between religion and vassalage, as Christianization was interpreted as a pledge of allegiance to the Spanish Crown. ${ }^{77}$ The chronicle mentions several cases of baptism, especially of Indian women, but it admits that this did not guarantee their loyalty to Spaniards, as in the case of Melchor, their "lengua" (Díaz del Castillo, Historia 8). This more realistic approach to the topic of conversion is combined with the attempt of Bernal Díaz to once again reinterpret the local religion and traditions. As such, he conveniently adapts the word "papa," also meaning "the Pope" in Spanish, to name the local priests, since as he claims, the Indians called them so. ${ }^{78}$ The chronicler, thereafter, calls them "papas" as consistently, as Cortés was calling the temples mezquitas. However, he 
reminds the reader from time to time about the difference, when referring to the priests as "adivinos y papas" (“fortune tellers and papas"; Díaz del Castillo, Historia 169). He also inserts other images and words from the Catholic religion into his account about the pagan rituals of the local population. For instance, a common practice among the Indians is zahumar ("fumigate with incense") Cortés and his men with what seems to be incense. Bernal also uses the word "altar" to refer to both the Christian altars that they build in the Indian cities and the local altars where the ritual sacrificed are made; even the local bread is compared to an "oblea" ("wafer"; Díaz del Castillo, Historia 251). It is important to note the difference between the use of such terms by Cortés, Bernal and Gómara, which is crucial for the differentiation between the reinterpretative and reimaginative approaches to Orientalization. While Cortés, and similarly Gómara, proceed to adjudicate terms like "mezquita" or "capilla" directly to the object, Bernal has a tendency to compare the aboriginal object to the Spanish one, which leads, as a consequence, to the recurrent use of comparative structures.

As Carman notes, on a larger scale, works like the one of Bernal Díaz and López de Gómara served to legitimize the conquest of the New World as an acceptable and even desirable way to spread Christianity in the Americas (43). Therefore, the Orientalization through reinterpretation and Europeanization of the Amerindians was intended to have a great impact on the popular minds: the use of the same religious terms for both Catholic Spaniards and pagan Indians brought them closer together and substantiated the purpose of the conquest steering it towards the religious Reconquest, much like in Medieval and Renaissance Iberia. To reinforce this idea even further, Bernal Díaz compares Tenochtitlán not to Venice, as Cortés and Gómara (Cortés, Cartas 41; López de Gómara, 
Segunda parte 147), but to "Constantinopla y . . toda Italia y Roma" ("Constantinople and the whole of Italy and Rome"; Díaz del Castillo, Historia 259). This not only implies its link to the long-established Christian tradition, but also insinuates that Tenochtitlán might be the third Rome, and just like Constantinople after 1453 it was in need of a Christian rescue. In this light, it is of no surprise that in terms of religion, Bernal Díaz remains a traditionalist and still follows the peninsular Orientalism of the first colonizers.

While Bernal's account tries to incorporate the Amerindians into the social paradigm rather than create an American substitute for the Moors, some traditional peninsular Orientalist tactics are still present in his work. At the very beginning of the chronicle he mentions that as they saw a big settlement in Cuba, they immediately named it "Gran-Cairo" ("Grand Cairo"), as the size and appearance of this city built by the Other reminded them of this Arab city (Díaz del Castillo, Historia 6; Díaz del Catillo, History 3). Another traditional element of peninsular Orientalism is the evocation of St. James, one of the symbols of the Christian Reconquest of Iberia. The battle cry "Santiago y a ellos," is one of such examples, where Santiago Matamoros ("St. James Moorslayer") becomes the patron saint of the Spaniards fighting the Indians ("In the name of St. James, attack!"; Díaz del Castillo, Historia 161). Bernal also notes that St. James was the saint patron of Cortés, along with St. John the Baptist and Virgin Mary (Díaz del Catillo, History 842). The alternate version of Historia verdadera also mentions the new church built on the ground of an old temple: "As we got possession of this great city [Tenochtitlán]. . . it was determined to place a church of St. Jago on the ground where this temple stood ... The church which now stand here is called St. Jago el Taltelulco" (Díaz del Catillo, History 148). At the same time, the chronicler is criticizing Gómara's 
evidence of the holy patronage that includes an actual appearance of the saint in front of Cortés and his men (Díaz del Castillo, Historia 83). Despite that, bernal essentially uses this image in the same Orientalist fashion as Gómara and other authors, for example, in novela morisca.

Another traditionalist aspect of the Historia verdadera appears at the very beginning and has to do with the image of teules, the local idols. While it becomes customary in the chronicle that the Spaniards overthrow them, introducing at the same time the elements of Christian religion, it is of greater importance the perception of these idols by both sides of the conquest. At the very beginning, Bernal Díaz makes an astonishing statement: "los ídolos del barro ... decían que eran de los judíos que desterró Tito y Vespasiano de Jerusalén, y que habían aportado con los navíos rotos en que les echaron en aquella tierra" ("the clay idols, they say, belonged to the Jews banished from Jerusalem by Titus and Vespasian, who came on the broken ships in which they were sent off"; Díaz del Castillo, Historia 18-19). In the alternate version there is also a similar passage, even more assertive, about the presence of the idols: "When the figures of idols which they brought were produced, it was believed that they were antiques conveyed to these countries by a Jewish colony, after the destruction of their city by Titus and Vespasian" (Díaz del Catillo, History 10). This passage is of special interest because it is almost a direct quote from Cortés's letter ${ }^{79}$ that used the same historic event to refer to the number of Indians killed by the conquistadors. There is a very significant difference though: while Cortés alienates both the Jews and the Amerindians from the hegemonic society, Bernal includes them into the social hierarchy through his reinterpretation of the 
Other, but at the same time, he perpetuates the Orientalized image of the Jews created in the Peninsula.

On the other hand, the local population sees Spaniards as teules: they require sacrifice, reverence, vassalage and they bring a new God (Díaz del Castillo, Historia 170, $175,182,187,214,237,295$, etc.). Cortés and his men take advantage of this perception and the Amerindians' believe that they were fulfilling an old prophecy. All of the above, like the interpretation of the local religion through Christianity and the local perception of the Spaniards, gave birth to religious syncretism, the manifesto of which can be seen in these words:

Y respondieron que no aprovechaban nada sus varas y flechas ni buen pelear ... porque una gran tecleciguata de Castilla venía delante dellos, y que aquella señora ponía a los mexicanos temor, y decía palabras a sus teules que los esforzaba; y el Montezuma entonces creyó que aquella gran señora que era Santa María y la que le habíamos dicho que era nuestra abogada, que antes dimos al gran Montezuma con su precioso hijo en los brazos. (Díaz del Castillo, Historia 271)

And they replies that their arrows and canes and great fighting skills were of no use, because the great tecleciguata of Castille preceded them, and this great lady put fear into Mexicans and she was saying words to her teules that encouraged them. Then Moctezuma believed that that great lady was the Virgin Mary who, as we said, was our advocate, and we had given him her image with her precious on in her arms. 
This fusion is impossible to imagine without the reinterpretative practices that took place on both sides of the Conquest.

However, all these served only as an anticipation of Bernal's Orientalism. It is not God, gold or land, but the people, both the Indians and the Spaniards, that are in the focus of his attention. It is the mutual influence of the representatives of the hegemonic and subaltern societies. Bernal Díaz accepts that both the Indians and the Spaniards go through a process of acculturation. Cortés and his soldiers not only learn to eat local food, but also practice local traditions (Lucena Salmoral 54). As such, they, at first surprised, accept the help of tamemes or "indios cargueros," but later on, the Spaniards demand that those servers be provided to them ("Indian carriers"; Días del Castillo, Historia 115). However, in the process of acculturation, the hegemonic group usually does not lose its essence and does not fall under the Amerindian influence, but uses common sense to take advantage of the situation. When and if a Spaniard is Americanized, he is banned from the hegemonic society.

Inadvertently and despite his intent of reinterpreting the new reality, Bernal Díaz proclaims the dominance of the colonizer over the colonized in all aspects, from social to religious. It is especially evident when comparing the lenguas or translators of Cortés, Doña Marina (La Malinche), Jerónimo de Aguilar and one of the Spaniards living with Indians, Gonzalo Guerrero. The latter is a Spanish conquistador who assimilated among the Indians. His appearance was completely altered by the Other: "dijo que estaba casado y tenía tres hijos, y que tenía labrada la cara e horadadas las orejas y el bezo de abajo" ("he said he was married with three kids, and his face was carved and his ears and lower 
lip pierced"; Díaz del Castillo, Historia 70). He seemed to forget the true religion and prefered not to join Cortés, who concludes that Guerrero has to be left alone because he “jamás será bueno" (“will never be good”; Díaz del Castillo, Historia 70). For Bernal, this is unacceptable, and in his eyes, Guerrero steps down the social ladder by joining the Other.

Opposite of him is the figure of the Europeanized Malinche or Doña Marina, her Christian name. The legendary interpreter of Cortés, La Malinche, as Bernal clearly states, was not only crucial for the Christianization of the Mexican Empire, but also saved the lives of the conquistadors and was extremely loyal to them (see, for instance, Díaz del Castillo, Historia 132, 153). Unlike Gonzalo Guerrero, she accepted the values of the hegemonic society. Even physically, she was more attractive than him and had powers and influence that corresponded to her noble origin. As a result, she enjoyed some privileges, so that even the Indians recognized her exceptional position. She became an alter ego of Cortés to the point that the Amerindians address him as "Malinche". In this light, the position of Doña Marina can be compared to the one of Avengalvón in the Cantar del mio Cid, revered but never equal to the Christian warrior.

Jerónimo de Aguilar occupies an intermediary, and therefore, more indicative of Bernal's Orientalism, position compared to the two previous characters. At first encounter, Bernal says about him that he "ni más ni menos era que indio" ("was exactly like an Indian"; Díaz del Castillo, Historia 69). His description even contains several Arabisms (albricias, alpargatas zarangüelles), a very rare phenomenon for Historia verdadera that can be found in only a couple of other descriptions, one of Moctezuma, and another one, of Tenochtitlán (Díaz del Castillo, Historia 95, 154). However, as 
Aguilar declares his loyalty to the Spaniards, Bernal's tone changes. He reminds the readers that Aguilar was a religious man; soon after that he claims Aguilar to be a loyal subject of Spanish Crown who is devoted and eager to convert the Indians ${ }^{80}$ Hence, his comeback to the hegemonic culture it is of no surprise. His religious vocation in past and in present allows him to advance on the social ladder. The behavior and perception of these three lenguas are similar to the Moors and the Moriscos in Iberia. These characters, the transgressors of the two worlds, are Orientalized based on their religious and cultural background; their position in the social hierarchy depends on their acceptance of the hegemonic society values.

Just like the Other in Iberia, the Indians in Historia verdadera are often portrayed collectively; only the noble ones are given a more detailed description or a chance to speak for themselves. This is of no surprise, taking into consideration that Bernal Díaz was very familiar with the chivalric novels and similar literature of the period. The only Indian who is portrayed in much more detail and is given a voice in the chronicle is the Emperor Moctezuma. Like the initial description of Aguilar, Moctezuma's description also contains Arabisms like carmesí, almizcle, algodón (Díaz del Castillo, Historia 95). His image almost mirrors the characteristics of Cortés ${ }^{81}$ himself, but always not to the same extent, creating a parallelism like Abencerraje-Narváez in El Abencerraje y la Hermosa Jarifa (see Chapter I for this description).

In sum, while Gómara's chronicle is structured around the figure of Hernán Cortés, Bernal's account tries to introduce another voice to the conquest, that of the soldiers who carried out the victory on their shoulders. As a result, in both cases, the Amerindian subject noticeably lacks the opportunity for self-expression. It is notorious 
that the voice of the Other, Orientalized in both chronicles for the purpose of legitimization of the conquest, is silenced. It creates a contrasting image of the representation of this silenced and Orientalized Other that only finds its voice in the Nahua rewriting of the conquest of Mexico, such as the chronicle by Domingo Francisco de San Antón Muñón (Chimalpahin) Quauhtlehuanitzin, ${ }^{82}$ where Nahua involvement in this historic process is given more protagonism, leading to the self-Orientalization of los vencidos ("the conquered").

As a result, Bernal's Orientalism does not avoid the inevitable influence of Peninsular Orientalism. However, due to the time gap, it is more subtle than that of his predecessors. It is based on the inferiority of the Other who is to be rescued by Christian society in order to become a part of it. However, there is a change in Bernal's writings. The chronicler reinterprets, rather than reimagines the reality of the New World and the relationships between the Amerindians and the Spaniards. He Orientalizes them in order to be able to appropriate this new entity and make it understandable to hegemonic society, but his approach is more realistic than that of his predecessors.

While Bernal's chronicle shows signs of a more advanced and changing Orientalism, Gómara's account is a more traditional Peninsular-like Orientalism that sees the overseas conquest as a continuation of the Christian Reconquest of Iberia. Hence, the chronicler's perception of the Amerindian Other and the Moorish Other seem to be closely related. As a result, Gómara uses the same techniques of reimagination of the reality of the New World, as, for instance, the novela morisca. At the same time, despite the dominance of the original paradigm of Hispanic Orientalism, there is a nascent attempt at reinterpretation of the Orientalized Other that manifests itself through 
ethnographic curiosity, and, to a lesser degree, through the religious perception of the New World. This interpretative Orientalization begins to play a more prominent role in later chronicles.

\section{§ 4. The Evangelists and the Ethnographers}

The impact of the authors' immediate experience as active participants in the process of conquest (or access to the participants of such events, as in the case of Gómara) and direct interaction with the Other for the purpose of its domination were very obvious in the two previous groups of works, the personal travelogues and the chronicles. Unlike them, the narrations by the evangelists, who, as in the case of the Franciscan friars were often viewed as the first ethnographers of the Americas, reveal a slightly different approach. While the first chronicles of the conquest refer numerous times to their presumed linguistic competence as a means to successfully carry out their campaign, the Franciscans, who established a relative missionary monopoly in the New World, understood very early the actual importance of truly understanding the language and the customs of the Other. Motolinía, for instance, notes that "la lengua es menester para hablar, predicar, convenser, enseñar y para administrar todos los sacramentos; y no menos el conocimiento de la gente" ("Knowledge of the Indian language is necessary for speaking, preaching, teaching and administering the Sacraments. Not less necessary is to be informed concerning the natives of New Spain”; Motolinía, Historia 88; Motolinía, History 187). Even the title of his chronicle, Historia de los indios de la Nueva España, 
while creating a parallelism with many other accounts, like Bernal's, emphasizes the position and the role of the Amerindians in the history of the colony.

Such approach "changed the friars into students of ethnography," and, as a result, numerous studies were carried out, predominantly, by the members of the Franciscan order, often with the endorsement of the Vatican (Baudot 72-73). Friars like Andrés de Olmos, Martín de la Coruña, Toribio Motolinía, Francisco de Las Navas, and most famously, Fray Bernardino de Sahagún embarked on an Amerindian Crusade with the conviction that only a deep knowledge of the Other would allow their mission to succeed. In an effort to do so, they paid special attention to the lingua franca of New Spain, the Nahuatl, creating in 1547 the first Nahuatl Grammar (Andrés de Olmos), and in 1555, the first Nahuatl-Spanish Dictionary (Alonso de Molina) (Baudot 92). However, this ethnographic approach did not prevent the friars from engaging in an Orientalist campaign that affected significantly the perception of the Other in the colony and the metropolis.

The evangelists, like the conquistadors, led their own religious campaign. They, more so than the others, perceived the continuity of the process of redemption of Christianity during the Latin American Crusade. In this light, the accounts of the evangelists offer a quintessential view of the Amerindian Other that combines religious and personal approaches that were despairingly represented in the previously analyzed chronicles. Due to the evangelists' religious background, the question of Amerindian identity, their qualities as human beings and their prospects in the Catholic world play a crucial role in the works by the friars like Fray Toribio Benavente Motolinía and Fray Juan de Zumárraga (Franciscans), Fray Julián Garcés, Bartolomé de Las Casas, and Juan 
de Torquemada (Dominicans), and others. On the other hand, like conquistadors, they were in need of justifying their actions, often defending their order against the others. Therefore, the accounts of the friars present an different testimony of the representation of the Other and its Orientalization by the hegemonic society that combined the approaches that became popular in the early colonial period.

Since in our focus is the Orientalization techniques of the dominant society, this section looks into the hegemonic approach to colonial subjects, in particular Motolinía and his Historia de los indios de la Nueva España (1541). While other accounts, ${ }^{83}$ like Fray Diego de Landa's Relación de las cosas de Yucatán, or especially Fray Bernardino de Sahagún's Florentine Codex may be of greater interest due to their ethnographic nature, ${ }^{84}$ Sahagún's alleged intent to represent America from the stand point of the Other differs from mainstream representations like Motolinía's. Such attempts, as well as the chronicles of discovery written by the Amerindians themselves, like the account of the conquest of Mexico by Domingo Francisco de San Antón Chimalpahin Cuauhtlehuanitzin Muñón, constitute another approach to the representation of the New World that can be a topic of a future analysis. As Browne notes, "in colonial situations, the colonizer and the colonized mimetically feed off each other as they "naturalize" the Other's world as part of their own. However, it can no longer be assumed that this happens on both sides of the equation for the same reasons" (168). Therefore, in order to be able to trace the development of Hispanic Orientalism, it is important to consistently view it from the same perspective.

For the purpose of this analysis, we will set aside the discussion about the composition of the "provisional, incomplete, and mutilated version" and the fate of the 
Historia de los indios de la Nueva España, confiscated, as many other evangelical chronicles in 1577 (Baudot 335, 120). Instead, we will concentrate on Orientalization techniques that make this chronicle a quintessential Orientalist manual of the colonial period, a sort of "work of propaganda," as described by Baudot (370). First and foremost, unlike the previous accounts, Motolinía tells the story of life after the conquest and not so much the story of the conquest itself. This gives him a certain perspective, similarly to Bernal Díaz, whose historical distance from the past allowed him to create a broader picture.

As Taboada indicates, after the conquest of America, religion becomes a litmus test for social and even racial segregation, and Motolinía indulges himself in the process of religious mythmaking (46). He is not shy to denounce the atrocities and severe exploitation of the Amerindians by the Spaniards and advocates for the local population, something that was not favorably viewed in the metropolis. However, his Orientalist approach changes its strategy. While the associations with Asia are still present, Motolinía's perception of the Other is not centered around the premise "like the Moors," as was typical of his predecessors, but rather "not like us, the Spaniards." While it seems like a minor divergence, it marks a significant change in the Orientalist approach, as it changes the reference (from another Other to hegemonic group, as well as directionality (from comparison to contraposition).

While the religious aspect is predominant in Motolinía's chronicle, his narration style is considerably more human than that of the conquistadors. Possibly influenced by the art of homiletics, Motolinía's text features direct addresses to the audience, almost poetic passages, and even a villancico. ${ }^{85}$ However, religious aspect, a crucial point for 
social segregation, impregnates every aspect of the chronicle. It is structured so that the reader gets acquainted first with the local pagan and demoniac traditions. These lead to the process of Christianization and, finally, the celebration of Christian religious practices, such as Easter and Corpus Christi as acknowledgement of the figure of Christ, baptism and confession, as a personal acceptance of Christianity, and finally, the eradication of polygamy as the ultimate proof of full acceptance of the new religion, according to the author (in this precise order!). This structure of the chronicle reveals the importance that Orientalization acquired as a technique of appropriation through interpretation, so skillfully used by Motolinía.

This approach also serves another purpose. The departing point for the definition of the Amerindian Other becomes "us" and European history rather than Islam. It is not by accident that Motolinía mentions Rome several times, as well as its legacy and Spain's links to it, for instance, when addressing Spanish and Holy Roman Emperor Charles V (1500-1558): "Emperador Romano, amado de Dios" or when he compared the Amerindian calendar to the Roman calendar ("Roman Emperor, Beloved of God"; Motolinía, Historia 72, 33; Motolinía, History 165). At the same time, the allusions to Asia are few. Most of them are biblical in nature, such as the references to Babylon, islands of Ophir, mountains of Gelboe, etc. (Motolinía, Historia 166-67; Motolinía, History 292-93). To reinforce the close link between the Other and "us," the author uses biblical structures to create an account about the New World using a formulaic text, widely accepted and recognized in Europe. This manifests itself in the enumeration of names that recall biblical passages attesting to the lineage of the tribes of Israel. ${ }^{86}$ 
The rather recurrent reference to Babylon is very significant for Motolinía: it directly links the Amerindian community, in which at the time of the Franciscan religious campaign more than forty languages were spoken, to the biblical scripts. But more importantly, such allusion was a confirmation of the Franciscan agenda in the New World. "The destruction of the new Babylon, the priestly and hierarchical Church" and the Second Coming of Christ were believed to result in the replacement of the current Church, "after the conversion of the Jews and the gentiles and the elimination of the infidels" (Baudot 78). This is indicative that, despite the desire to give protagonism to the Amerindian Other, the Reconquest Other was always present in the discourse of hegemonic society. It can also be seen in Motolinía's Oriental references, although there are only few exceptions to the evasion of non-biblical Oriental allusions: "para que de estos se servían grandes señores de esta tierra, como ahora hace Gran Turco, de eunucos” or "hacen también alpargatas como los del Andalucía" ("The lords of this land are served by these dwarfs as the Grand Turk is by eunuchs"; "They also make slippers, like those worn in Andalusia"; Motolinía, Historia 146, 198; Motolinía, History 269, 332). And even these comparisons are different in nature that the one seen previously: they serve as a reference rather than directly attribute certain Oriental characteristics to the Amerindian Other.

Motolinía also presents the reader with the list of the ten American plagues ${ }^{87}$ mimicking the infamous plagues of Egypt. It is not surprising then that he calls America “otra Egypto en idolatría” (“a second Egypt in point of idolatries”; Motolinía, Historia 156; Motolinía, History 278). In this case, this comparison is Europeanized, as it has already passed through the purgatory of biblical tradition. Motolinía even concludes that 
the transatlantic colony "es capaz de producir ... todo lo que hay en Asia, y en Africa, y en Europa; por lo cual se puede llamar otro Nuevo Mundo" ("is capable of producing in abundance everything found in Asia, Africa and Europe; wherefore this land can rightly be called another New World"; Motolinía, Historia 158; Motolinía, History 281). Therefore, the departing point of such comparison is Europe, and not as much Asia, and America gradually becomes an independent actor, different from the previous peninsular Other and capable of creating its own dichotomy with the Old World.

The Orientalization process in Motolinía's account, as in previously reviewed chronicles, has two vectors: self-Orientalization and the Orientalization of the Other. Like the conquistadors, the friars needed to justify their religious campaign, which led to the reinterpretation of their own role in the process of the conquest of America. In Chapter 4 of the Third Treatise, Motolinía carefully reviews the behavior of the Spaniards and other friars, comparing the humildad and pobreza ${ }^{88}$ ("humility" and "poverty") of the Franciscans to the seven deadly sins, under the spell of which fell too many of his compatriots. ${ }^{89}$ The concepts of humility and especially poverty, the pillar aspects of the Franciscan order, were crucial to the friars, and Motolinía constantly finds their manifestations in his fellow friars, as well as in the Amerindians.

On the other hand, there is a great deal of idealism in portraying the local population and their Christian devotion. Browne notes that, unlike in later works like Sahagun's, Motolinía's view "simply lacked the conceptual framework that would have been necessary to perceive the superficiality of the Nahuas' conversion" (106). Motolinía also laments that they are treated by the members of the superior class as their slaves. They are prompt to fall into the deadly sins, like drunkenness and sodomy, of course, 
mostly before the Franciscan missionary campaign. However, the image of the Amerindians needed some positive traits to support the possibility of their redemption. Motolinía finds them not in their superficial behavior that can be changed, but in the inherited characteristics: he praises their peacefulness, natural talents, and openness to the Christian word. For instance, he notes that "estos indios y todas las animalias de esta tierra naturalmente son mansos ... pero hábiles son para cualquier virtud, y habilísimos para todo oficio y arte, de gran memoria y buen entendimiento;" they are "simples y sin ningún mal, no codiciosos de intereses, tienen gran cuidado de aprender" ("yet, the Indians are fit for any virtue, most fit for a new trade or art, having a retentive memory and possessing a good understanding"; "simple people, well disposed, neither avaricious nor ambitious. They take great pains to learn”; Motolinía, Historia 88; Motolinía, History 187-88).

The chronicle is full of idyllic descriptions of Indian devotion and readiness to battle el demonio ("the devil"). It is he who is their main opponent, which, once again, refers to the Christian opposition of good and evil. The locals not only long for baptism and reject polygamy willingly; they seem to be completely acculturated in the eyes of Motolinía. As a proof of this, he mentions an Indian who sold his possessions to give limosna ("alms"), or the natural understanding of the concept of honradez and honestidad ("honor" and "honesty") by a young Indian girls serving the pagan idols who restrain themselves from sexual relations and make a sort of penitencia ("penance"), or even fast (Motolinía, Historia 94, 43-45).

Another example are the visions of the saints and apostles, frequent in Motolinía's account. They are sometimes shared by both the Spaniards and the locals. Unlike in the 
previous accounts, where Santiago Moorslayer was by far the most popular and recurrent vision, in Motolinía's Historia there are various saints and apostles who appear to both the Indians and the Spaniards. Some of these visions include, naturally, St. Francis, St. Anton (128), Archangel St. Michael (72), and, of course, Santiago Moorslayer (71). The latter does not appear, however, in America. This vision is mentioned as a part of the campaign against the Moors and the Jews to liberate Jerusalem where the representatives of the New World fight alongside the Holy Emperor's troops.

The inhabitants of the colony receive Motolinía's blessing and are portrayed as ready for a change. Their lands also hold great potential. Despite being "destruída" (sic) "de plagas" because of the "enfierno que estaba en México" as a result of paganism, it is usually described in very positive terms as "esta tierra muy sana" and "rico valle y fertilísimo," abundantísima de todo género de ganados" ("devastated by . . plagues"; "the city of Mexico, which looked like as if it had been brought from hell itself"; "this land is very healthful"; "the rich and fertile valley"; "It abounds exceedingly in all kinds of cattle"; Motolinía, Historia 19, 24, 6; Motolinía, History 95, 104, 80). As in the case of Amerindians, while the customs of the city of Mexico deserve to be reprimanded by Motolinía, he admires its inherited grandeur and richness. As a matter of fact, the word "grandeza" ("grandeur") becomes a customary adjective applied to everything in and about the city. It is important to note, however, that despite all of these similarly equalizing characteristics, the Other always remains in the inferior position and needs guidance from the hegemonic society.

In Motolinía's Historia, like in the other chronicles, one can find abundant references to the marvelousness and the secrecy of the land, as well as superlative 
adjectives describing it. ${ }^{90}$ However, the context of most of them is religious, which, once again, refers to the reinterpretative nature of the author's Orientalization. The ethnographic curiosity of this approach also resulted in the use of Christian religious terms to describe the local practices, although not as prominently as in the other chronicles, the most dramatic being "gran príncipe o pontífice mexicano, que era como papa" ("the great chief of Mexico, the pontiff who was, as it were, their pope"; Motolinía, Historia 31; Motolinía, History 113). Some local words, like teutl, are also introduced into the text with their respective description, a technique that was typical for the chronicles of the early colonial period (Motolinía, Historia 25).

What is strikingly different is the notable lack of Arabisms in the text. ${ }^{91}$ This echoes the above mentioned relative absence of parallelisms with the Arab world, especially in a non-biblical context. Even more indicative is the insertion into the chronicle of the letters of Don Antonio Pimentel who conveys to the Emperor the story of the military campaign in Jerusalem, where the "ejercito de la Nueva España" fights against the Jews and the Moors ("the army of New Spain"; Motolinía, Historia 69; Motolinía, History 162). This is indicative of the fact that the Amerindian Other starts to be interpreted as a part of the dichotomy Europe-America rather than Europe-Asia. It represents a significant change in the Orientalist paradigm in the New World.

As a result, the Amerindian Other in Motolinía's chronicle is reinterpreted in order to be appropriated and form part of the hierarchical structure of colonial society. Paraphrasing Walden Browne's conclusion about the work of another Franciscan, Fray Bernardino de Sahagún, "he labored intensely - if not entirely successfully - to make all that jarred with a Western schema fit into a preexisting perspective ... in order to 
produce what can only be understood as a highly orchestrated text" (96). However, it is not viewed any more entirely as a part (or a mirror) of the Muslim world that Spain had to face for centuries; instead, America forms a new dichotomy with the Old World. In this sense, the Historia de los indios de la Nueva España reveals cardinal changes in the original paradigm of Hispanic Orientalism in the New World; the changes that were first expressed in the works of explorers and conquistadors and developed in the subsequent works of the chroniclers of the New World.

\section{§ 5. Conclusion}

Hispanic Orientalism is not static, but rather changing in nature. Its historical development and relocation from Spain to Latin America caused the most significant changes in its original paradigm. In its process of development, the mimicry of the discourse of power, implied in Said's concept of Orientalism, played a crucial role. It was the inner impetus of adjustment to the evolving relationship between the hegemonic and the subaltern cultures that defines Hispanic Orientalism in its migration from Europe to America. It was important at the time to establish Christian dominance, as the process of consolidation of the Spanish Empire was not yet complete and there was a need to reiterate the claims of not only Christendom, but also of Spaniards as such, especially under the imminent Ottoman threat.

Therefore, the transatlantic migration of the Orientalist paradigm from the Iberian Peninsula to colonial Latin America was a crucial moment for the formative process of Hispanic Orientalism in the New World. The relational model between hegemonic 
Spanish and subaltern cultures both in Medieval Spain and the colonized New World undergoes an unavoidable process of change. It was based on cultural and mental differences between the subaltern Others, Moors and Amerindians, and the historical shift in powers. As well, it arose from the differences between the social strata of the dominant class in Spain and the conquistadors. Even though, the Conquest of the New World was perceived as a continuation of the Reconquest and the Crusades, the relocation of the paradigm and a new geopolitical situation, as Spain became one of the largest empires in the world at the time, and the Islamic threat to Europe, influenced the changes in the original paradigm of Hispanic Orientalism.

Paraphrasing Michael Householder's emphasis on the "encounter, invention, narration" (1) as mechanisms of imagining the Other, Hispanic Orientalism arose from the encounter, reinvention and later reimagination of the Other. When the Spanish Kingdom confirmed its European and Plus Ultra dominance, the discourse of power reshaped the Orientalist approach of the new colonial nation. This gradual change can be seen in the chronicles of the conquest and the accounts by the colonizers and religious men. During the early Renaissance, Christian ideals play a crucial role in the process of Orientalization of the Other, since the measuring scale for the latter was not fully established. In the later period, the acceptance of Christianity and its values served as a litmus test for the differentiation between "us" and the "Other," as well as led to sectarianism and social disparity.

Initially, Columbus and Cortés's strategy generally followed the appropriation through idealization and reinvention approach, typical of Peninsular Orientalism at the time. The abundance of Arabisms and comparisons to the Muslim countries reveals the 
underlying opposition between the Amerindians/Moors and Europe. The ensuing chronicles about the New World had a broader perspective, both historically and geographically, so they could not rely on imagination only: since it would jeopardize the credibility of their Orientalist approach. Therefore, chroniclers like those of Gómara and later Bernal Díaz del Castillo chose a different technique - that of reinterpretation of the existing reality. The acknowledgment of the differences of the New World weakened the ties between the Amerindian Other and the traditional Orient.

However, it is in the evangelical accounts like Motolinía's, where we can clearly see the direction of the development of the colonial Orientalist paradigm. Despite the prominence of the religious aspect and the ethnographic interpretation through a religious lens, his account reveals that the Orientalist approach, as well as its underlying dichotomy, have experienced significant alterations. While Motolinía is still searching for the (Christian) appropriation of the Other through reinterpretation, he also gives protagonism to America itself. His allusions to Asia are rare and mostly biblical, and his comparisons often involve Europe rather than Muslim countries. In this sense, the Amerindian Other starts to be interpreted as a part of the Europe-America dichotomy rather than Europe-Asia. This represents a significant change in the Orientalist paradigm in the New World.

In sum, the original paradigm of Hispanic Orientalism had traversed an enormous length through space and time. In its transatlantic journey during the period when the link between the New and the Old World was especially strong, it managed to adapt to the new historical circumstances. Two major changes can be observed in the paradigm. One of them was the movement away from the reinvention of the Other as a mechanism for 
appropriation, since it was deemed unreliable and not trustworthy for the audience.

Instead, reinterpretation took place. The other key change was the gradual substitution of Asia by America in the Orientalist dichotomy in the New World. These two alterations, established during the early colonial period, were adopted in the late colonial and the early Independence periods, determining social segregation, such as the castes system in Mexico, and further Orientalization of the Other from a new perspective. This experience, the possibility to switch the elements in the dichotomy in an Orientalist relationship, will provide an Orientalist model for the Independence period when the hegemonic powers change once again.

\section{NOTES}

${ }^{29}$ At the same time, the fifteenth and seventeenth-century travels and expeditions were a break though in geography and navigation. Christopher Columbus reaching in 1492 Las Indias that later were confirmed to be a new continent was only the beginning of a great journey of discovery. Even though most of the expeditions had economic rather than scientific purpose, it is their scientific value that preserved the names of the explorers and sailors in the history. In 1513, Vasco Núñez de Balboa for the first time crosses the continent discovering "el mar del Sur," in other words the Pacific Ocean. Another expedition, the consequences of which it is impossible to overestimate, is the one of Ferdinand Magellan y Juan Sebastián Elcano (1519-1522). Sailing along the South American cost, they were the first Europeans to reach Tierra de Fuego and the Pacific Ocean through the Strait of All Saints, or Strait of Magellan, as it is known nowadays. Magellan never saw the result of his expedition, as he died in Philippines where his crewmembers were the first Spaniards who reached the islands. It was Elcano, who finally returned to Seville in September 1522 with 18 members of the original 265 member crew (Tunón de Lara 286). However, it is impossible to overestimate the result of the expedition of Magellan-Elcano, as it was a practical prove of the spherical shape of the Earth and it gave an estimate of how fast one could circumnavigate it.

Parallel to this process are the exploration campaigns in the New World. As such, between the years 1540 and 1550, all the territory between Río de la Plata and California was explored. Several expeditions were launched from the Caribbean to discover the lands on the North. In 1513, Juan Ponce de León discovered what was first believed to be 
an island that was called Florida. In 1565, the first city in North America, St. Augustine, was founded by Pedro Menéndez de Avilés. Earlier, Hernando de Soto was the first European to cross Mississippi. Parallel to his endeavors was the expedition of Francisco Vázquez de Coronado y Luján in present day Colorado during which the Great Canyon was discovered (Tuñón de Lara 290-91).

In the present day Central and South America during the sixteenth century, numerous expeditions explore the immense territories, establishing in them political and economic dominance of Spain. Many of the cities that become a center of sociopolitical life of the region are founded during that period, among them, for example, Lima, the capital of Viceroyalty of Peru (1543). The process of creating of sociopolitical centers in different regions of the American triggered cultural development, especially in the center of the Viceroyaly of Nueva España and Peru. The first printing house was founded in Mexico already in 1535, in Lima it appeared in 1584. The first universities opened their door to students in Santo Domingo, Mexico and Lima (the last two - around 1555) (Tuñón de Lara 292, 297).

${ }^{30}$ Antonio Domínguez Ortiz compares the use of workforce in the mines of Nueva España, where the labor of free workers and blacks was used, and the mines of Potosí in Peru. In the latter, a system of mita was implemented. This system, of Incaic origin, demanded the mandatory participation of all the members of the society in the working process. Even though, there was a rotation among workers and they were paid certain salary, the work conditions were so hard, that the indigenous population from the neighboring territories left for other regions in order to avoid exploitation (Tuñón de Lara 295). This, along with other consequences of the conquests (numerous diseases and exterminations), resulted in considerable demographic changes in the New World, some of the regions of which, as the Caribbean, losing almost of all its indigenous population.

The fast enrichment of the Spanish Crown due to the active exploitation of precious metals, especially in the region of Potosí and Zacatecas, was another consequence of the discovery of the Americas. However, it had both positive and negative impacts: on one hand, it resulted in the delayed economic downfall of Spain and, at the same time, in the continuation of the Orientalization process as one of the ways to legitimize the exploitation of the local and imported workers. In the sixteenth century, Spain acquired about 7,400,000 kilograms of silver and 150,000 kilograms of gold from the New World. However, most of this wealth did not stay in the country, as it was used for the Spanish military and diplomatic campaigns in Europe. The drastic economic downfall of Spain occurred between 1540, when war depth constituted $68 \%$ of the kingdom's income, and the end of the sixteenth century, when it was eight times bigger than the yearly income of the kingdom (Kamen 154). Spain's economic downfall and the ways it extracted and spent the resources of the New World resulted in the gradual decline of its role in the Colony throughout the seventeenth century. However, by that time, Spanish social and economic practices had been established in Americas, and along 
with them the principles of interacting with the Other, which were brought to the New World from Europe. As a result, it coined its own principles of Orientalization that naturally were rooted in the Iberian Orientalist practices of the time of the Reconquest and the Post-Reconquest.

${ }^{31}$ See the section dedicated to the Diarios of Christopher Columbus.

${ }^{32}$ It is argued sometimes that the religious mission was the real reason for Columbus to launch his trips to the New World, as he was searching for "paraíso terrenal" ("the eathly paradise"), which according to cartographers of the time, could be found in that direction.

${ }^{33}$ Spanish control over the New World was carried out by two institutions. One of them, Consejo de las Indias (Council of the Indies) was founded by Carlos V and had very broad authority. Another institution, Casa de Contratación (The House of Trade), even though it was officially overseen by Consejo de las Indias had total control over the trade with the New World (Tuñón de Lara 292, 382). Established in Seville, in 1717, Casa de Contratación was moved to Cadiz where it influenced considerably the life of its inhabitants and the very profile of the city.

34 The Spanish word "criollo" can be translated into English as "Creole." Nevertheless, there is a significant difference between these terms. Both comprise the ideas of some kind of mixture, but Creole refers to racial mixture between Europeans and Africans, and criollo, to a person of European descent born in the Americas.

${ }^{35}$ See the following:

Nuestros Señores, este presente año de 1492, después de Vuestras Altezas haber dado fin a la guerra de los moros que reinaban en Europa y haber acabado la guerra en la muy grande ciudad de Granada, adonde este presente año a 2 días del mes de enero por fuerza de armas vide poner las

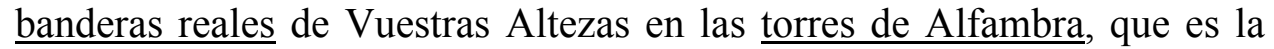
fortaleza de la dicha ciudad, y vide salir al rey moro a las puertas de la ciudad y besar las reales manos de Vuestras Altezas y del Príncipe Mi señor, y luego en aquel presente mes, por la información que yo había dado a Vuestras Altezas de las tierras de India y de un príncipe llamado Gran Can, que quiere decir en nuestro romance Rey de los Reyes, como $\underline{\text { muchas veces él y sus antecesores habían enviado a Roma a pedir doctores }}$ en nuestra santa fe porque le enseñasen en ella y que nunca el Santo Padre le había proveído y se perdían todos los pueblos creyendo en idolatrías o recibiendo en sí sectas de perdición, Vuestras Altezas, como católicos cristianos y Príncipes amadores de la santa fe y acrecentadores de ella y enemigos de la secta de Mahoma y de todas idolatrías y herejías, pensaron 
de enviarme a mí, Cristóbal Colón, a las dichas partidas de India para ver los dichos príncipes, y los pueblos y tierras y la disposición de ellas y de todo y la manera que se pudiera tener para la conversión de ellas a nuestra santa fe; y ordenaron que yo no fuese por tierra al Oriente, por donde se costumbraba de andar, salvo por el camino de Occidente, por donde hasta hoy no sabemos por cierta fe que haya pasado nadie. Así que, después de haber echado fuera todos los judíos de todos vuestros reinos y señoríos, en el mismo mes de enero mandaron Vuestras Altezas a mí con armada suficiente me fuese a dichas partidas de India . . (Colón 15-16, my emphasis)

. . our Lords: This present year of 1492 , after Your Highnesses had brought to an end the war with the Moors who ruled in Europe and had concluded the war in the very great city of Granada, where this present year on the second day of the month of January I saw the Royal Standards of Your Highnesses placed by force of arms on the towers of the Alhambra, which is the fortress of the city; and I saw the Moorish King come out of the gates of the city and kiss the Royal Hands of Your Highnesses and of the Prince my Lord; and later in that same month, because of the report that I had given to Your Highnesses about the lands of India and about a price who is called "Grand Khan," which means in our Spanish language "King of the Kings"; how, many times, he and his predecessors had sent to Rome to ask for men learned in our Holy Faith in order that they might instruct him in it and how the Holy Father had never provided them; and thus so many people were lost in idolatry and accepting false and harmful religions; and Your Highnesses, as Catholic Christians and Princes, lovers and promoters of the Holy Christian Faith, and the enemies of the false doctrine of Mahomet and of all idolatries and heresies, you thought of sending me, Christóbal Colón, to the said regions of India to see the said princes and the peoples and the lands, 
and the characteristics of the lands and of everything, and to see how their conversion to our Holy Faith might be undertaken. And you commanded that I should not go to the East y land, by which way it is customary to go, but by the route to the West, by which route we do not know for certain that anyone previously has passed. So, after having expelled all the Jews from all of your Kingdoms and Dominions, in the same month of January Your Highnesses commanded me to go, with suitable fleet, to the said region of India." (Columbus 17-19).

${ }^{36}$ Having arrived in America, Columbus shows no doubt in his Diary about the land being a part of the Far East, unlike some of his sailors. Numerous notes relate newly discovered lands to Cathay and Cipango, and Columbus even uses his authority to impose his beliefs upon his crew (for instance, during his second voyage he make everybody sign a declaration that Cuba is not an island but a part of mainland Cathay) (Gil, Varela 21723; Morison 277; Flint 128). There were similar precedents that Columbus knew about, as the one of Bartolomé Díaz that might have served as an inspiration for the Admiral. While the hesitation of the sailors is important as it questions the Orientalist theories of Columbus, it is even more indicative of their persistency that neither the Admiral's son nor Las Casas mention this episode in their writings (Gil, and Varela 216). Gil and Varela note:

Francisco Niño, vesino de Moguer, piloto de la caravela Niña, dixo que para el juramento que avía hecho que no oener yó ni vido isla que pudiese $t$ tresientas e treinta e cinco leguas en una costa de Poniente a Levante y aun y que veía agora que la tierra tornava al Sur Suduest ;no acababa de andar y al Suduest y Oest y que ciertamente no tenía dubda alguna que fuese la tierra firme, antes de muchas leguas navegando por la dicha costa, se fallaría tierra donde tratan gente política de saber y que saben el mundo etc. (Gil, and Varela 219)

${ }^{37}$ See:

This is the first voyage and the courses and way that the Admiral

Don Cristobal Colón took when he discovered the Indies, summarized except for the prologue that he composed for the king and queen, which is given in full ... (Translated by me $-S$. T.). 
Este es el primer viaje y las derrotas y camino $\bar{Q}$ hizo el almirante don xpōūal Colon quando dscubrio las yndias puesto sumariamēte sin el prologo $\bar{Q}$ hizo a los reyes $\bar{Q}$ va a la letra ... (Columbus 16-17)

${ }^{38}$ The figure of Columbus appeared to be reinvented several times in history not only in the writings of Las Casas. His origins, as well as his burial place remain in question and are disputed by the researchers. For instance, while the widely accepted theory of Genovese precedence of Columbus is shared by a number of researchers, other, like Menéndez Pidal note that he might have belonged to a Jewish Spanish family forced into exile because of the persecution that began in Iberia in 1391 under the mandate of the Archdeacon of Ecija (La lengua 9-10). This and similar disputes are indicative that the figure of the very "discoverer" of America underwent a process of Orientalization by the hegemonic power in an effort to attest to its own importance through the reinvented image of the one of the most important historic figures of the period. Similarly, the writings of Columbus, and later on, other discoverers and conquistadors of the New World, Orientalized the new reality in order to aggrandize their role and seek social and economic welfare.

Menéndez Pidal also established the periods for language acquisition of Columbus that are closely related to his travels and his professional experiences (La lengua 19-25). This is important as its shows the gradual "Hispanization" of Columbus (through Portuguese), which, together with the Menéndez Pidal's theory of the Spanish-Jewish origins of his family completes the circle of Orientalization of Admiral's figure. In a way, it can be compared to the representation of the Indians as the ones who forgot the God and whose comeback was facilitated by Spain and the Spanish conquistadors and evangelists.

39 “juraban muchos hombres honrados españoles que . . . cada año vían tierra al Oueste de las Canarias" ("many honorable Spaniards . . . / swore / that every year they saw land to the west of / the Canaries" ( $\mathrm{sic}$ ); Colón 18; Columbus 25; August 9, 1492).

40 The association of the Arabic word kalb 'dog' can be one of the possible etymologies of the renown personage of Shakespeare's The Tempest (1611) (Taboada 95).

41 "Esta gente es muy mansa y muy temerosa, desnuda . . . sin armas y sin ley" ("these people are very gentle and very / timid, naked . . without / weapons and without law”; Colón 54; Columbus 133; November 4, 1492). 
42 "Todos de buena estatura, gente muy fermosa" ("all of good stature - very handsome people"; Colón 31; Columbus 69; October 13, 1492).

${ }^{43}$ Columbus's and Las Casas's reimagination and reinvention of the Other leads to a construction of the image that is quite similar to the image of the Moors in the Iberian Peninsula. It is crucial though that Columbus separates the Indians from the Africans. Often, this contraposition is based on color. This way, Columbus includes the Indians into the Spanish societal structure, rather than alienating them, as happened to the Jews in Medieval Iberia. It facilitates considerably the task of the Christian conquest of the Americas, or its Reconquest, as the Indians seemed to know the true God, whom they lost to their pagan rituals.

${ }^{44}$ For instance, alquicel, alberca, adobe, mezquita, almaizal (yashmak, water tank, adobe, mosque, thin mantel; Cortés, Cartas 21; Cortés, Letters 30-35).

${ }^{45}$ Codex Mendoza. Ed. James C. Clarke. 3 vols. London: n. p., 1938. Print.

${ }^{46}$ Guamán Poma de Ayala, Felipe. Nueva crónica y buen gobierno. Eds. John V. Murra, Rolena Adorno, and Jorge L. Urioste. 3 vols. Madrid: Historia, 16. 1987. Print. Fol. 404.

${ }^{47}$ See Cortés, Cartas 14, 17 and Cortés, Cartas 64-65 for textual reference.

48 "Y el capitán . . . les dió a entender que en ninguna manera él se había de partir de aquella tierra hasta saber el secreto de ella para poder escribir a vuestra majestad relación de ella" ("The captain them answered them, giving them to understand that on no account would he leave until he had learnt the secrets of the land and might send Your Majesties a true account of it"; Cortés, Cartas 15; Cortés, Letters 19).

${ }^{49}$ There is a tendency to adjudicate those characteristics more to his enemies, while he restrains himself from direct negative comments about his Indian allies or the Indians who treat him friendly: he describes in detail the grandeur of Moctezuma's court (Cortés, Cartas 66-69), and the Tlaxcaltecas are referred as "eran muchos y muy fuerte gente ... con sus plumajes que acostumbraban traer en las guerras . . que peleaban con mucho denuedo y ánimo" "“they were many and very strong . . . dressed in feathers they wear in battle . . . they fought with great courage and ferocity"; Cortés, Cartas 36-37; Cortés, Letters 57-58).

50 "Los aposentos . . . son muy amoriscados y en las partes adonde no alcanzan piedra, hácenlas de adobes y eneálanlos por encima . . . Hay casas muy frescas . . . de cinco patios dentro de una sola casa, y sus aposentos muy aconcertados, cada principal 
servido que ha de ser por sí. Tienen por dentro sus pozos y albercas de agua ...." ("the rooms are ... in Moorish fashion. In those parts where there is no stone they make their houses of adobes, which are whitewashed ... There are houses ... very cool and have . . . as many as five courtyards in a single house, and the rooms around them very well laid out, each man having a private room. Inside there are also wells and water tanks"; Cortés, Cartas 21; Cortés, Letters 30).

${ }^{51}$ This tradition of using Arabized toponims and Ababisms in general will persist for some time in America. See the legend about the city of Xequechakán that was considered to be called so after the xeque, the Moorish ruler who came to these lands and was later killed when the locals revolted against his oppression (for a detailed version, see Antonio de Ciudad Real, Tratado curioso y doctor de las grandezas de la Nueva España, 353). Taboada also gives the follwoing example:

En Brasil, la carta de Pedro Vaz de Caminha informaba que los indios también hablaban "beribería", por lo que no se los podia entender . . .Cei contestaba citando algunos antropónimos, entre los cuales figuraba el de "Mahoma “. En otras áreas guaraní, el cronista Jerez señala la semejanza de su lengua con el árabe; Martín del Barco Centenera y Johannes de Laet hacen mención de los mahomas sobre el Río de la Plata. (129-30)

${ }^{52}$ However, the absence of a direct comparison can be also indicative of the fact that the word "mezquita" was used to denominate a non-Christian temple, hence the English translation of it as a "shrine". Cortés continues referring to local temples as "mezquitas" also in the other letters that compose Cartas de relación.

${ }^{53}$ When describing the Templo Mayor of Tenochtitlán, he writes: "Entre estas mezquitas hay una que es principal, que no hay lengua humana que sepa explicar la grandeza y particularidades de ella . . . la más principal es más alta que la torre de la iglesia mayor de Sevilla ... de maravillosa grandeza y altura" "“Amongst these temples there is one, the principle one, whose great size and magnificence no human tongue could describe . . . the most important of these towers is higher than that of the cathedral of Seville ... of remarkable size and stature"; Cortés, Cartas 64; Cortés, Letters 105-06).

${ }^{54}$ See, for instance the use of the word "escaramuza" and "escaramuzar." There terms, typical for a Moresque novel, describe the often glorious for Spaniards encounters with the Indians on the battlefield. The concept of individualism and personal glory are very important for the participants of such combats, similarly to scenes in Guerras civiles de Granada.

${ }^{55} \mathrm{He}$ starts his account by presenting the Spaniards as an example of good Christians and vassals who are under God's protection as they carry out their mission: 
Demos gracias a Dios, que tanto bien y honra nos ha guardado y dado. Pidámosle por merced nos ayude y guíe a conquistar esta tierra y nuevo mar que descubrimos y que nunca jamás cristiano vio, para predicar en ella el santo Evangelio y bautismo, y vosotros sed lo que soléis y seguidme, que con el favor de Cristo seréis los más ricos españoles que a Indias han pasado, haréis el mayor servicio a vuestro Rey que nunca vasallo alguno hizo al señor, y tendréis la honra y prez de cuanto por aquí se descubriere, conquistare y convirtiere a nuestra fe católica. (López de Gómara, Primera parte 108)

Let us praise the Lord who saved and gave us so much good and honor. Let us ask him to help us in his mercy and guide us to conquer this land and the new sea that we discovered that no Christian ever saw, to preach in it the Holy Gospel and the baptism. And you be what you are and follow me, as with God's help you will be the richest Spaniards who passed through the Indies; you will the greatest servants to your King, more than any of his vassals and you will have honor and fame of everything that is here discovered, conquered and converted to our Catholic faith.

${ }^{56}$ The image of Hernán Cortés is opposite to this pejorative description. He is portrayed as a great warrior and strategist, whose honor and honra run in the family: "sus padres ... no solamente los honraban sus vecinos por la bondad y cristiandad que conocían en ellos, sino que hasta ellos mismos se percibían de ser honrados en todas sus palabras y obras" " "his parents were not only respected by the neighbours because if their kindness and religiousness, but they themselves felt respected in their words and deeds"; López de Gómara, Segunda parte 9). Even his appearence is of a hero: "Era Hernán Cortés de buena estatura, rehecho y de gran pecho; el color ceniciento, la barba clara, el cabello largo. Tenía gran fuerza, mucho ánimo, destreza en las armas" ("Hernán Cortés was tall, robust and of wide chest, greyish color, with light colored beard and long hair. He was very strong, of great spirit and skillful with weaponry"; López de Gómara, Segunda parte 444). In Historia general the reader almost always sees the glorious victories of Cortés and his men, and much less often is faced with the scenes of defeat, suffering or other problems, something that Bernal Díaz severely criticized later in his own account.

${ }^{57}$ The descriptions of the latter are simple and even negative. He is portrayed as a foreigner and he always seems to lack strength and support: "le faltaba el favor del rey," "trajo mal despacho," pobremente vestido" ("he lacked the king's favor"; "had no luck"; "poorly dressed"; López de Gómara, Primera parte 31-33). Gómara even attributes the discovery of the New World by Columbus not only to the support of the Catholic kings who conveniently had "el pensamiento puesto en echar a los moros del reino de 
Granada," a metaphor of the future Latin American crusade, but to mere luck, as, according to Gómara, a Spanish sailor who had reached America before Columbus, "falleció . . . en casa de Cristóbal Colón, en cuyo poder quedaron las escrituras de la carabela y la relación de todo aquel viaje largo" ("had their mid set on expelling the Moor from the kingdom of Granada"; "died in the house of Christopher Columbus who took possession of the ship's log and the account of that long journey"; López de Gómara, Primera parte 29, 32). Hence, Columbus was only taking advantage of the greatness of Spanish sailors.

It is also indicative of the reimagination of the figure of Cortés the fact that Gómara's other chronicle, Crónica de los corsarios Barbarroja, completed while he was writing Historia general, traces parallelisms between Cortés's military success and importance of the conquest's consequences, and the one of 'Arjul Barbarossa, the elder brother of Khair ad-Din, whose victories are sometimes attributed by Gómara to the former ${ }^{57}$ (Roa-de-la-Carrera, Gómara 36, 45). Carman points out though that despite the parallelism in the portrayal of these "great men," they are not treated alike. In the dedication to his Crónica, Gómara distinguishes two historic genres: narration of someone's life and narration of the fate of great men, like emperors or conquistadors, whose trajectory is closely connected to history. While the Barbarrossa brothers are depicted biographically, Cortés's life is so closely related to the conquest that Historia general almost falls into the second category (87-89). Another crucial difference lies in their ethics: for Gómara, in the comparison between the Cortés's ethics and Barbarossa's states that there exist "the pinnacle of virtue and the sea of vice" (Carman 95). As a result, there is a difference in the images of the two chronicles. Muslim and adversary to Spanish kingdom, the Barbarrossa's nobility and personal glory allowed for the comparison to a Christian conqueror like Cortés, in the same way that Abencerraje could be compared to Narváez (see Chapter I for this description).

${ }^{58}$ See López de Gómara, Primera parte 5, 7, 29, 30, 35, 37, 86, 10, 110, 127, 142, 212, 213, 371, 376, etc.; López de Gómara, Segunda parte 27, 101, 111, 132, 134, 400, etc.

${ }^{59}$ See López de Gómara, Primera parte 5, 29, 32, 36, 50, 70, 83, 84, 102, 111, 122, 128,143,147, 202, 207, 362, 374, etc.; López de Gómara, Segunda parte 8, 12, 23, $24,27,33,57,59,75,151,423,429,431$, etc.

${ }^{60}$ This suffix is used extensively in both parts of the Historia general. See López de Gómara, Primera parte 5, 29, 36, 43, 62, 70, 84, 140, 143, 146, 158, 163, 202, 203, 204, 207, 234, 355, 362, 373, 374, 384, etc.; López de Gómara, Segunda parte 8, 57, 58, 75, 103, 131, 133, 140, 143, 146, 162, 151, 157, 404, 419, 423, 429, 431, etc.

${ }^{61}$ See descriptions in the first part where the following words of Arabic origin are used: zaragüelle, alpargata, alfiler, alboroque, algodón; azúcar, mazapán, algodón, 
aljófar, nácar; bodoque, almohadilla, algodón, almizcle, alquitrán, atabal (López de Gómara, Primera parte 82, 127, 142-46) or jarro, algodón, almaizales, alpargatas, alfileres; azúcar, aceite, alfiler, zaragüelle; arrejaque, aljófar; azotea, almacén (López de Gómara, Segunda parte 18, 23, 81, 156).

${ }^{62}$ They "se casan con cuantas quieren . . . no hermana, ni madre ni hija. No las quieren extranjeras ni desiguales," allusion to polygamy and Islamic marital restrictions; "son ellos celosos, y ellas buenas de su cuerpo," living in a type of harem, where the master sometimes "cortaba narices y miembro, y hasta brazos, a los criados que guardaban y servían a sus mujeres" " "get married with as many as they want, not sisters, mothers nor daughters"; "used to cut noses and penises, and even hands of the servants who guarded and attended to their wives"; López de Gómara, Primera parte 122, 199).

63 "Se mudan como los árabes," "acostumbran lavarse dos o tres veces al día" as the Mulsims do before payers, and even embalm their deceased: "los asan, en fin, después de muertos, y aquello es embalsamar" "“they are nomadic as Arabs"; "they have a habit of washing up two or three times a day"; "shortly, they fry them after death, and it means embalming"; López de Gómara, Primera parte 122-23).

64 "Vieron por tres veces al del caballo rucio picado pelear en su favor contra los indios ... era Santiago, nuestro patrón. Hernán Cortés quería mejor que fuese San Pedro, su especial abogado" ("they saw three times the one on the roan horse fighting with them against the Indians . . . It was St. James, our protector. Hernán Cortés preferred him to be St. Peter, his patron saint"; López de Gómara, Segunda parte 46).

${ }^{65}$ The religious influence is quite prominent in Gómara's argument. It is important to note that it is evident not only in the open comparisons, arguments and ideology, but also can be seen on a structural level. For instance, in the first part, the chapter entitled "El sitio de las Indias" with its precise measurements resembles the biblical description of lands inherited by each of the Israeli tribes:

De Cotoche o Yucatán hay ciento diez leguas al río Grande, y quedan en el camino la punta de las Mujeres y al bahía de la Ascensión. Del río Grande, que cae a dieciséis grados y medio, hay ciento cincuenta leguas hasta cabo del Camarón, contadas de esta manera: treinta del río o puerto de Higueras, de Higueras a puerto de Caballos otras treinta, y otras treinta de Caballos al puerto del Triunfo de la Cruz, de él al puerto de Honduras otras treinta, y de allí al cabo del Camarón, veinte, de donde calculan setenta al cabo de Gracias a Dios, que está a catorce grados. (López de Gómara, Primera parte 24)

The portion that went to the tribe of Judah for their families extended to the border of Edom in the wilderness of Zin in the Negeb on the 
southern end. Their southern boundary ran from the edge of the Salt Sea at the south bay southward to the slopes of Scorpion Pass, then through Zin south of Kadesh-barnea, curving back to Karka through Herzon and Addar, then past Azmon, and along the brook of Egypt out to the sea. (The Holy Bible. The Berkley Version, Joshua 15.1-4)

The description of the temples of Tenochtitlán in the second part resemble the description of the biblical tabernacle or Solomon's temple (note the repetition of the number " 3 " and the structure of the temples in both descriptions):

Al templo le llaman teucalli ... Todos o casi todos, son de una forma; y por tanto, con hablar del mayor bastará para entenderse, y así como es general en toda esta tierra, así es nueva forma de templos, y creo que ni vista ni oída más que aquí. Tiene este su templo el sitio cuadrado. De esquina a esquina hay un tiro de ballesta. La cerca de piedra con cuatro puertas, que responden a las calles principales que vienen de tierra por tres calzadas que dije, y por otra parte de la ciudad que no tiene calzada, sino muy buena calle. En medio de este espacio hay una cepa de tierra y piedra maciza, esquinada como el patio, y de cincuenta brazas de ancha de un cantón a otro. Cuando sale de tierra y comienza a crecer el montón, tiene unos grandes relejes. Cuanto más crece la obra, tanto más se estrecha la cepa y disminuyen los relejes ... (López de Gómara, Segunda parte 154-55)

The house which King Solomon built for the Lord was 90 feet long, 30 feet wide and 45 feet high. The porch in front of the temple itself was 30 feet long, as was the width of the house, and its width was 15 feet in front of the house. ... The house was built of stones dressed at the quarry ... The door of the lowest side rooms was on the right side of the house and by winding steps one could go up to the middle side chambers and from the middle to the third. (The Holy Bible. The Berkley Version, Kings 6.2-3, 7-8)

Here one can also compare Gómara's and Bernal's descriptions of the overview of Tenochtitlán with its three roads stretching out from the lagoon and the biblical description of the Paradise and its four rivers: "Todo el cuerpo de la ciudad está en el agua. Tiene tres clases de calles anchas y agradables. Las unas son de agua sola, y las otras, de tierra y agua" (López de Gómara, Segunda parte 147-48). "Le dejo que mirase su gran ciudad y todas las más ciudades que había dentro en el agua . . y y de allí vimos las tres calzadas que entran en Mérico, que es la de Iztapalapa. Que fue por la que entramos cuatrodías había; y la de Tacuba, que fue por donde después . . . salimos huyendo .. . y la de Tepeaquilla" (sic) (Díaz del Castillo, Historia 258-59). "There was also a river flowing out of Eden to water the garden, and from there it was divided and 
became four rivers. The first is named Pishon; it flows around all the land of Havilah, where there is gold, high quality gold; aromatic gum, too, and onyx stone. The name of the second river is Gihon; . . . the name of the third river is Tigris . . . The fourth river is the Euphrates" (The Holy Bible. The Berkley Version, Genesis 2.10-14). These tacit comparisons would be easily perceived by the devoted population who would be more inclined to favor the Christian conquest of the New World for the sake of its salvation from the pagan oblivion it lived in.

66 "Se fue a Tecpan, que es un palacio, y allá se informó particularmente por los lenguas, cuáles eran o no caballeros, y . . . así les envió el don: si era hidalgo y buen soldado, bueno y con mayordomo, y si no, y marinero, no tal y con lacayo" ("he went to Tecpan, which is a palace, and there he learned in detail through interpreters who was a nobleman and who was not. And respectively, he sent them gifts: if nobleman and good soldier, he sent a good gift with a butler; if not noble or a seaman, not such a good gift and with a lackey"; López de Gómara, Segunda parte 134).

${ }^{67}$ See López de Gómara, Primera parte 109, 129, 133, 135, 134, 211; López de Gómara, Segunda parte 16-19, 80-83, 168-69, etc.

${ }^{68}$ His comment seems to draw an infernal picture that should have served as a motivation for the true believers who were looking into participating in the American crusade:

Los hombres de tierra firme de Indias comen carne humana, y son sodométicos más que ninguna otra generación. Ninguna justicia hay entre ellos, andan desnudos, no tienen amor ni vergüenza, son como asnos, abobados, alocados, insensatos; no tiene en nada matarse ni matar; no guardan verdad si no es en su provecho; son inconstantes, no saben qué cosa sea consejo; son ingratísimos y amigos de novedades; se precian de ser borrachos, pues tienen vinos de diversas hierbas, frutas, raíces y grano; se emborrachan también con humo y con ciertas hierbas que los saca de quicio; son bestiales en los vicios; ninguna obediencia ni cortesía tienen mozos a viejos ni hijos a padres; no son capaces de doctrina ni castigo; son traidores, crueles y vengativos, pues nunca perdonan; inimicísimos de religión, haraganes, ladrones, mentirosos, y de juicios bajos y apocados; no guardan fe ni orden, no se guardan lealtad maridos a mujeres ni mujeres a maridos; son hechiceros, agoreros, nigrománticos; son cobardes como liebres, sucios como puercos; comen piojos, arañas y gusanos crudos dondequiera que los encuentran; no tienen arte ni maña de los hombres; cuando se olvidan de las cosas de la fe que aprendieron, dicen que aquellas cosas son para Castilla y no para ellos, y que no quieren mudar de costumbres ni dioses; no tienen barbas, y si alguna les nace, se 
la arrancan; con los enfermos no usas piedad ninguna, y aunque sean vecinos y parientes lo desamparan al tiempo de la muerte, o los llevan a los montes a morir con sendos trocitos de pan y agua. Cuando crecen se hacen peores; hasta los diez o doce años parece que han de salir con alguna crianza y virtud; pero de allí en adelante se vuelven como brutos animales; en fin, digo que nunca crió Dios tan cosida gente en vicios y bestialidades, sin mezcla de bondad o cortesía. Juzguen ahora las gentes para qué puede servir la cepa de tan malas mañas y artes. Los que hemos tratado, hemos conocido esto de ellos por experiencia . . (López de Gómara, Primera parte 373)

${ }^{69}$ La Malinche is not given any protagonist in Gómara's chronicle. Her name is only mentioned as a reference, and it is her Christian nameonly, for instance: "Cortés les hizo hablar con Marina" or "según dijo Marina" or "les preguntó con Aguilar y Marina" or "lo examine con Marina y Aguilar" (López de Gómara, Segunda parte 59, 62, 73, 101). Gómara gives a very brief description of her story, noting appropriately that "esta Marina y sus compañeros fueron los primeros cristianos bautizados en toda la nueva España" (López de Gómara, Segunda parte 55).

${ }^{70} \mathrm{He}$ insists that "afirmo que lo que en este libro se contiene es muy verdadero, que como testigo de vista me hallé en todas las batallas . . y no son cuentos viejos, ni Historias de Romanos de más de setecientos años" ("I affirm that what this book has is very true; as I, as an eye witness, participated in all the battles . . . they are not old stories nor seven hundred year old stories of Romans"; Díaz del Castillo, Historia 1; or "I will proceed with truth"; Díaz del Castillo, History IV).

${ }^{71}$ Here is further, all the translations of Historia are mine unless otherwise indicated. This is due to the fact that the Spanish and the English versions of the Bernal's text used for the analysis are based on two slightly different manuscripts. The Spanish version is based on the original draft of the chronicle, edited by 1632, while the English version is based on the manuscript altered by the later chronicler Adarzo y Santander.

72 Among Bernal's arguments against the "escritos viciosos" ("vicious writings") of the official chronicler of the Spanish Crown are that "en su historia en todo lo que escribe se enganó" and "todo que en el caso pone es muy al revés, por más buena retórica que en el escribir ponga" ("he was deceived in everything he writes about"; "everything that he describes is wrong despite the use of good rhetoric"; Díaz del Castillo, Historia 1, $43,108)$.

${ }^{73}$ For instance, see Díaz del Castillo, Historia 21, 49, 87, 97, 178, 193. 
${ }^{74}$ For other instances of the use of this Word, see Díaz del Castillo, Historia 113, $215,238,239,242,272,377$.

${ }^{75}$ Here is the list of some of the Arabic loanwords used mostly to describe the everyday life of the Spaniards (the words are mentioned multiple times in the chronicle, however, here only one reference is given for brevity; all quoted in Díaz del Castillo, Historia): zaino (about a hourse; 57), algodón (57), jinete (58), alarde (62), albañil (66), jarro (67), albricias, zaragüelles, alpargatas (69), carmesí, almizcle (95), alazana (about a horse; 112), azotea, albarrada (154), alférez (166), aljófar (262), alguicil (277), bodoquillo (281), calafate (313), alarde (339), etc.

${ }^{76}$ Some of the examples are algodón, jinete, albañil, azotea, carmesí ("cotton, horseman, mason, roof, crimson"; Díaz del Castillo, Historia 57, 58, 69, 95, 154). For the etymology of the words refer to The Dictionary of Royal Spanish Academy: Real Academia Española. Diccionario de la lengua española. 22nd ed. Real Academia Española, n. d. Web.

77 "Les dijimos cómo éramos cristianos y vasallos del mayor señor que hay en el mundo, que dice el emperador don Carlos" or "le dieron a entender . . . las cosas de nuestra santa fe y el gran poder del emperador nuestro señor" ("we told them that we were Christian and vassals of the greatest lord in the world"; "they made him understand the things about our Holy Faith and the great power of our lord the emperor"; Díaz del Castillo, Historia 95, 281). It is curious that the expression "mayor señor que hay en el mundo" without the referral to the emperor could have been easily interpreted as a reference to God, and not only the tribute to Carlos V who was the Emperor of the Holy Roman Empire at the time of Cortés's campaign.

78 “eran sacerdotes de los ídolos que en Nueva España se llaman papas" ("they were priests of the idols who in New Spain are called papa"; Díaz del Castillo, Historia $10)$.

79 “Los españoles habían tomado por fuerza la grande ciudad de Temixtitan, en la cual murieron más indios que en Jerusalén judíos en la destrucción que hizo Vespasiano" ("the Spaniards had taken by storm the great city of Temixtitan, in which there had died more Indians tan Jews in Jerusalem during the destruction of that city by Vespasian"; Cortés, Cartas 96; Cortés, Letters 159).

80 "buena lengua y fiel" who in his talks to the Indians "aconsejaba que siempre tuviesen devoción y reverencia a la santa imagen de nuestra señora y a la cruz" ("good interpreter and loyal"; "advised that they be always devoted and reverend of the holy image of Our Lady and the cross"; Díaz del Castillo, Historia 70-71). 
${ }^{81}$ While at the beginning of the Historia verdadrera Bernal laments that the main focus both of Cortés's Cartas and Gómara's chronicle is on the conquistador himself and his role in the campaign, he does not avoid Orientalizing of the figure of Cortés. He is idealized, noble, wise, benevolent towards the Indians and good with the soldiers, but above all, he is the defendant of the true faith, almost like the legendary Cid. Even the way Bernal addresses the conquistador, "nuestro Cortés" ("our Cortés) echoes "mío Cid" (Díaz del Castillo, Historia 275). Bernal Díaz in his account of Cortés's life not only reinforces the impression of the conquistador's power, but also his deep knowledge of history and law by attributing to him numerous high-sounding speeches that show great familiarity with Roman history. However, these can be attributed to the influence of chivalric novels, popular at the time in Iberia, with Bernal Díaz, and even Cortés himself (Pagden 48-49).

While Cortés is depicted as a very literate man of his time, which can be deduced, for instance, from the use in his account of the Mexican conquest of both Latinisms and references to the Roman heroes, like "certum quid," "ab initio" or "un hecho troyano," his education was not as sophisticated as it appears to be ("Trojan deed"; Cortés, Cartas 66, 68, 4). As Pagden notes, "several years' legal training, popular fantasy and the traditions of medieval Spain" - that is what defined Cortés style and thinking (49). Nevertheless, both Bernal Díaz and even more Gómara create a more sophisticated image of the conquistador, for whom "ya echada estaba la suerte de buena o mala ventura, como dijo Julio César sobre el Rubicón" ("the fate the good or bad luck was already determined, as Julius Cesar said at the Rubicon"; Díaz del Castillo, Historia 149).

On the other hand, Bernal himself was known to be fond of reading chivalric novels, which could inspire him to add to his chronicle his own touch. In this light, the following expressions seem to belong to the chronicler rather than to Cortés himself. While admiring the view of Tenochtitlán, Bernal and the others see it as "las cosas del encantamiento que cuentan en el libro de Amadís" ("the enchanted things described in the book about Amadis"; Díaz del Castillo, Historia 238). Similarly, the following words seem to be taken directly from a chivalric novel: "Dénos Dios ventura en armas como al paladín Roldán" ("God give us fortune in arms like the Paladin Roldan"; Díaz del Castillo, Historia 91; Díaz del Castillo, History 51).

82 See: Chimalpahin Cuauhtlehuanitzin Muñón, Domingo Francisco de San Antón. Ed. and trans. Susan Schroeder, Anne J. Cruz, Cristián Roa-de-la-Carrera, and David E. Tavárez. Chimalpahin's Conquest: A Nahua Historian's Rewriting of Francisco López De Gómara's La conquista de México. Stanford: Stanford U P, 2010. Print

${ }^{83}$ Also see the chronicle of the representative of a less influential in the Colony Dominicans Fray Diego Durán and Jesuit missionary José de Acosta.

${ }^{84}$ However, the role of Sahagún as the pioneer ethnographer and anthropologist is sometimes questioned: "Sahagún has no place as the father of modern anthropology, 
nevertheless, anthropology's ongoing struggle to come to terms with the diversity of cultures and human behavior may still lead to a better understanding of Sahagún" (Browne 71).

${ }^{85}$ See Treatise I chapter 15 (Motolinía, Historia 67):

Para qué comía

La primer casada,

Para qué comía

La fruta vedada.

La primer casada

Ella y su marido,

A Dios han traído

En pobre posada

Por haber comido

La fruta vedada.

Also see: "¡Oh, tierra del Perú . . !," “Nobles de España, llorad . . !," "Oh, qué río de Babilonia . . !" (“Alas! land of Peru . . !”; "Ye nobles of Spain, bewail . . !”; "Alas! What a Babilonian river”; Motolinía, Historia 166; Motolinía, History 291-92).

${ }^{86}$ See the descriptions in the Epístola proemial (Motolinía, Historia 3-7) that enumerate the parents and their offsprings of the rules of what was in Motolinía's time New Spain. They closely resemble the detailed biblical descriptions of the tribes of Israel. It is not casual that such description is placed before the beginning of the actual chronicle. It sets the tone for the reader and inspires him to see more similarities between the Amerindian Other and the Christian religion and its practices, something that was of high importance for the Franciscans.

${ }^{87}$ The plagues for Motolinía are directly related to the "codicia" ("greed") of the conquistadors. They are (Motolinía, Historia 13-17):

1. Chickenpox and measles (Viruelas, sarampión);

2. Death of many as a result of the conquest of Mexico;

3. Famine;

4. The calpixeques (exploitation of Black);

5. Indian tributes;

6. Golden mines;

7. The way Mexico City was built;

8. Slavery;

9. Indian workers of the mines;

10. Division among Spaniards. 
${ }^{88}$ The use of these two words is prominent in the chapter. The words "humilde" and its derivatives are used 8 times and "pobre" and such, 7. These adjectives are applied to both the Franciscans and the Indians, which establishes a special link between them in the eyes of the reader, serving as a proof of a successful Christianization campaign by these friars.

${ }^{89}$ Of especial concern to him is also the greed that is constantly present in his descriptions: “¡Oh, cuántos por esta negra codicia desordenada del oro de esta tierra están quemándose en el infierno!" ("Oh, how many, how many, on account of this black inordinate greed for the gold of this land are burning in hell!"; Motolinía, Historia 23; Motolinía, History 101). Moreover, Motolinía denounces ruthlessly the abuses of the Spaniards and even shows examples of divine retribution, as in the story of the Spaniard who used to call Indians "perros" ("dogs") and who was consequently torn to pieces by a tiger (Motolinía, Historia 109).

${ }^{90}$ See, for instance, Motolinía, Historia 1, 30, 52, 62, 110, 115, 117, 118, 162, 177 and 19,118 respectively.

${ }^{91}$ There are only few Arabisms used by the author. Among them are: atabal (19); zaraguelles (65), and alpargatas (198). 


\section{CHAPTER 3.}

\section{The Transition: Hispanic Orientalism before and after Latin American Independence}

\section{§ 1. Introduction}

At the beginning of the sixteenth century both the Latin American colonies and the metropolis underwent significant sociopolitical changes. At the beginning of the conquest of Latin America, Iberia, as well as the whole of Europe were under the imminent Ottoman threat. At the same time, Spain, as Taboada points out, occupied rather subordinate position among its peers because of its economic circumstances, lack of significant technological and military advances, and even the number of inhabitants; it is during the sixteenth century when the Iberian Peninsula took the first steps to minimize the gap between and "sus contrincantes extraeuropeos, para superarlos en varios terrenos en el XVII, competir ventajosamente en el XVIII y dominarlos en el XIX" ("its non-European so that it surpassed them in several fields in the seventeenth century, successfully competed with them in the eighteenth, and dominated them in the

nineteenth"; Taboada 28). Beginning with $1580,{ }^{92}$ the fearful Ottoman menace that, in a sense, provided a framework for the Christian crusade in the New World, was gradually disappearing. Nevertheless, this did not mean that the Islamic threat was eliminated from the popular mind. The latent wars with and within the Islamic world, and the piracy from Moroccan and Algerian costs (Taboada 124-28, 171) maintained and nourished the paradigm of relationship with this Other up to modern times. 
The overseas colony was also experiencing some sociopolitical and economic changes, which led to its independence from the metropolis, weakened by the Napoleonic wars. Toward the beginning of the eighteenth century, the complex socioeconomic and political relationships in Latin American colonial society were already established. The originally flexible society gave way to an almost feudal organization. The system of the encomienda, established in the early colonial period to control and exploit the indigenous population, underwent a process of considerable scrutiny on the part of the metropolis, especially after the denouncements by the Dominicans, like Bartolomé de Las Casas, which led to its abolishment at the beginning of the eighteenth century. Adopted in 1680, La Recopilación de Leyes de Indias, established a rigid system of relationships between different racial groups, the implementation of which, however, was not ideal. The changes in the system of taxation affected first of all the indigenous population and caused numerous revolts in the second half of the eighteenth century, like the one of Túpac Amaru II (1780-1783). The latter had strong repercussions rippling across Peru and reaching territories from Tucumán in modern Argentina to New Granada, proving that "Madrid could not fully control the situation [in the colonies] at the same time as it weakened the structure in order to implement the change" (MacLachlan 101).

However, the crisis of the encomienda along with the ongoing discussions about the legitimacy of the Amerindian campaign and the rational capacity of the local population, on one hand, and, on the other, the sixteenth-century treatises of Fray Matías de Paz and Juan López de Palacio Rubios, stipulating that the king "could not seek to extend his dominions or enrich himself" though a colonial occupation, "set a 
problematic precedent for formulating a coherent narrative of colonization ... creating an obstacle for the construction of a discourse of domination" (Roa-de-la-Carrera, Infamy 189-191). Many, such as Gregorio López and John Major, theorized about the legality of the Spanish enterprise, proclaiming the use of force as an exclusive measure "if the heathen refuses to tolerate the peaceful preaching of the Gospel," having in mind mostly "the infidel of the later Middle Ages" (Parry 17). John Major's, thesis, however, are of great importance for the development of Orientalism in Latin America. His second argument in justification of the conquest, not a theological but a secular one, consisted in bringing civilization to the barbaric population of the New World. In this sense, Major was, as Parry notes, "the first publicist to apply the Aristotelian theory of natural servitude to the natives of the New World or to any entire race" (18). This is a very important step forward that is retaken and revised in the late colonial and early independence period, when the dialogue between civilization and barbarism gains a new perspective, as in the works by Sarmiento.

The arduous and prolonged debate about the legitimacy of the conquest led to the strengthening of the desire, on the part of the hegemonic society, to reassure itself and the others about the imminent need for colonial intervention and the dominance of the hegemonic class. And what better mechanism than reinterpretation of the Other could come in hand for such a task? As a result, this tendency, latent in the early colonial period gained more force towards the beginning of the nineteenth century, when the rupture with the former colonizer produced a different type of Orientalism.

It is during this phase of the pre-independence period that the phenomenon of criollismo became more and more powerful. Initially, it was not associated with 
separatism, but rather aimed to defend the interests of the Indies and prevent their discrimination by the metropolis (Tuñón de Lara 379-81, 385). However, at the beginning of the nineteenth century when Napoleon's invasion weakened Spain and detracted its attention from the colonies, it was the criollo (Creole) movement and thought that became the engine for emancipation. As Browne notes: "Monarchical - and even supposedly liberal - Spain had become a millstone around the necks of criollos (Creoles), who realized during the turn-of-the-century European wars that they did not need Spain as an intermediary . . they needed . . to forge their new identities" (46). At the beginning of the nineteenth century, the realization of this dissonance resulted in the independence movement led by criollos who would assume the role previously played by the Peninsular colonizers. Inspired by the example of the United States that gained independence in 1776 , the new leaders of the New World were ready to take the place of the colonizer (Tuñón de Lara 388). This moment initiates a new period when the nature of Hispanic Orientalism undergoes a major revision due to dramatic changes in the social and political circumstances.

The original paradigm of Hispanic Orientalism, which had traveled an enormous distance throughout space and time, continued to develop in the colonies. The early colonial period is characterized by a growing tendency to implement a reinterpretive approach to the Other for the purpose of its appropriation. Parallel to this process, was the gradual substitution of Asia by America in the Orientalist dichotomy in the New World. In the late Colony period, these changes resulted in social segregation, such as the creation of the caste systems in Mexico and the further Orientalization of the Other from a new perspective. Nevertheless, the dramatic change in power during the 
independence movement that altered the axes of the colonizer and the colonized resulted in the need to review the long-established approach to the Other. The hegemonic powers, represented now by the criollo elite, had to define themselves in opposition to a new entity. While in the early colonial period the crucial point for such differentiation was the Amerindian Other; towards the $19^{\text {th }}$ century the differentiation from Europe, the old colonial alma mater, became indispensable for the creation of independent nations. As Latin American nations moved towards their independence the need for selfassurance and differentiation grew stronger. As a result, the transitional period of Hispanic Orientalism is characterized by the gradual shift from an interpretative to a differentiating Orientalist approach. It was no longer the colonizer Orientalising the colonized, but rather the former colonies Orientalizing the self and the others to assert their right for independency.

The close co-existence of the colonizer and the colonized in the New World could not but lead to the deep mutual influence between the hegemonic self and the Other. For instance, Browne notes that "art historians have documented the increased Europeanization of the indigenous artwork" during the colonial period that manifested in "hybrid of indigenous and European features" (160-61). This tendency continues into the later centuries and can be seen in the paintings representing different castes in Latin America, the so-called pinturas de castas, the caste paintings. The pre-established images of the Other and the self, deeply rooted in popular imagery and the literature, were the raison d'être of verses like the following that was circulating in New Spain by 1821: 
Desconfía de indio con barbas,

De gachupín lampiño,

De mujer que hable como hombre,

De hombre que hable como niño. (León 70)

Do not trust an Indian with a beard,

Or a beardless Spaniard, indeed,

A woman who speaks like a man,

And a man who speaks like a kid.

The first two verses are very indicative of the direction of Orientalization and self-Orientalization in Latin America. Taboada notes in regards to the function of appearances: ${ }^{93}$

Durante siglos, los varones de la Cristiandad latina se habían distinguido de los muslimes o los judíos por su ausencia de barba. Al arribar al Nuevo Mundo anotaron, acertadamente o no, que su modalidad lampiña era compartida por los amerindios, cuya escasa pilosidad empezó a convertirse en un rasgo básico de las descripciones. Que los europeos comenzaran a portar barba a partir del siglo XVI es un hecho, y en alguna medida, aunque con seguridad la causalidad no es tan directa, el cambio nos señala que el Otro por excelencia, del cual había que distinguirse, no era ya el judío/muslim, sino el amerindio. (232) 
This reveals a new tendency that will be formulated during the later colonial period and will be developed fully during the post-independence: the necessity of differentiation from the Other, whatever form it takes.

Not surprisingly, while during the colonial period mimesis was the way of "Othering" (Browne 158), with Independence, "en busca de raíces, se opuso la herencia indígena a la hispánica" ("in the process of searching for their the roots, they opposed the Indigenous heritage to the Spanish"; Portilla 16). This resulted in the reevaluation of the process and the outcomes of the American conquest, which led to the reinterpretation of history from the point of view of the Latin American self, such as, for example, the negative associations of the figure of Hernán Cortés and La Malinche. The period between 1763 and 1830 was marked by the accelerating disintegration of many of the American colonies, which "constituted a water-shed between two epochs and changed the character of European imperialism" (Fieldhouse 100). However, the time alignment and the likeness of the independence movements across Latin America was striking: "Although the early stages of the struggle for independence in Mexico are more ambitious in that lower classes were involved, it is generally recognized that, early on, the struggle for Mexican independence fell into the same pattern of a triumphing politico-economic elite that is recognizable in other Latin American independence movements" (Browne 46). It is of no surprise then that similar Orientalist tactics were used across America.

This chapter analyses the manifestations of Hispanic Orientalism during the transitional period, which spans over the later Colonial and early Independence periods. In order to trace the gradual changes in the paradigm, we review its implementation in 
the seventeenth century poetry and prose by Sor Juana Inés de La Cruz (1648-1695), in the eighteenth century castas paintings, which strived to depict the rigid colonial structure in pre-independence Latin America. Finally, we look into the Orientalism of the early Independence period in Facundo: civilización y barbarie (1845) by Domingo Faustino Sarmiento. The analysis of this broad scope of narrative and pictorial representations of Orientalism allows us to clearly delineate the tendencies of the period, which will define the late-Independence and modern Orientalism in Latin America.

\section{$\S$ 2. Orientalization through Self-Reinterpretation in the Late Colonial Period: “Mundo iluminado” by Sor Juana Inés de La Cruz}

During the time when the overseas colonies of the Spanish kingdom became more and more autonomous from the metropolis and were gradually acquiring a protostate shape, a new question arouse, that of their right to exist and their place in the glorious scripts of European-dominated history. While the Americas continued to be the Other of Europe, the colonies strived to be included in the European tradition. Only such acceptance would give the New World enough power and grounds to later differentiate itself from the metropolis, launching the independence movement. As Latin American nations moved towards their independence this need for self-assurance only grew stronger. During the post-independence period, it manifested itself in further differentiation not only from the metropolis, but also from the other Others, including the Oriental Other. 
This intricate process of finding its place in European history and culture while still preserving a certain degree the autonomy can be observed in the prose and poetry of Sor Juana Inés de La Cruz (1648-1695). While her literary predecessors emphasized the need to include the Amerindian Other into Colonial society by reinterpreting itself for the purpose of its appropriation by the hegemonic group, Sor Juana's approach is different. She offers the reader an insider's view, which makes her claims of the inherent value of "nuestra Imperial Méjico" for European society more substantial (“Our Imperial Mexico" (Neptuno alegórico); De la Cruz, Obra 792).

In a way, she launches a campaign to de-Orientalize the Colony, whose Orientalized image was created and perpetuated in the chronicles and travelogues of the discoverers and colonizers. In order to carry out her mission, Sor Juana engages in a process of self-Orientalization, originated in the polyglot nature of Spanish society, and, as a consequence, of Hispanic Orientalism, whose influence was analyzed by Julia Kushigian, pointing to its impact on the later works of Latin American authors (Orientalism 26; Sor Juana 168). Anna More, theorizing the concept of the Archivo criollo ("Creole Archive"), makes a similar observation as regards the local documents that were gathered and reinterpreted in order to "domesticate" the common past (73). Sor Juana's self-Orientalization partially follows this tendency. It is based on the desire to insert America into European imagery and history. Both her poetry and prose abound with biblical, Greek and Roman mythological and historic references. In one of her most extensive works, Neptuno alegórico (1680), a symbolic welcoming of the twenty-eighth Viceroy of New Spain, Tomás Antonio de la Cerda, Count De Paredes, Marquis De la 
Laguna (Arenal 27), Sor Juana supplies the following arguments, tracing the evolution from pagan traditions to Christianity:

Y esto hicieron no solo con las deidades, pero con todas las cosas invisibles ... y también con las de quienes era la copia difícil o no muy agradable, como la de los elementos, entendiendo por Volcano el Fuego, por Juno, el Aire, por Neptuno el Agua y por Vesta la Tierra ...

... Decoro de mejores luces que aprobó el Real Profeta ... Y de nuestro Redentor dice el sagrado cronista San Mateo . . . (De la Cruz, Obra 777-78)

And they did it not only with deities, but with all the invisible things and also with those whose copies were difficult to produce or were not pleasant, such as the elements, understanding the Fire as Vulcan, the Air as Juno, the Water and Neptune, and the Earth as Vesta.

The decorum of the brightest lights endorsed by the Regal Prophet ... And the holy chronicler St. Mathew says about our Savior. . ${ }^{94}$

Among these deliberations, the image and the allusions to the Colony are carefully and almost always tacitly inserted in the narration and the broader philosophical and religious discussions. This makes Sor Juana's claims more assertive, as she establishes the parallelism between two historical processes. On the one hand, Sor Juana portrays a positive development (guided by God's word and knowledge) from the original polytheistic worldview of the ancients to the monotheism of advanced society; on the other hand, she portrays the Colony as a Utopian possibility for the metropolis. 
This becomes the leitmotif of Sor Juana's poetry and prose. As George Thomas states, her works reveal her constant "consciousness of Mexico's peripheral position in the Spanish Empire and criollo ... pride" (37).

The juxtaposition of the two worlds and, at the same time, the continuity between the decline of the one and the rise of the other, as will be later theorized by Oswald Spengler in The Decline of the West, are the basis for Sor Juana's selfOrientalization. For instance, in Primero sueño, published first in 1692, one of Sor Juana's most iconic poems, she not only lays the basis for the opposition between the "nuestro Hemisferio" and the other one, but most importantly, she creates a juxtaposition using the traditional Orientalist terms of "su Occidente" versus "nuestro Oriente" or "Ocaso ... fugitivo" versus "Mundo iluminado" ("our Hemisphere"; "their Occident"; “our Orient”; “fugitive Sunset”; "enlightened World"; De la Cruz, Obra 20001). Especially the second pair of attributes is indicative of Sor Juana's selfOrientalization practices, as ocaso also symbolizes the decline while the light that is brought to the New World represents its rebirth and is the sign of future prosperity. ${ }^{95}$ It is only logical then that in the conclusion of the poem, where the reinterpreted and inferior Oriental "rüina" ("ruins"; De la Cruz, Obra 201) is symbolically represented as the place where the sun sets, and the new world is associated with the sunrise. Hence in the poem, Orientalism not only reinterprets the Other but also there is a nascent intent to differentiate from the Other, in its initial phase, the Oriental Other. Similar tendencies can be observed in the other poetic and prose works by Sor Juana.

On the other hand, as it was noted earlier in the late Colony, in the process of interaction with the Other, the Asian references and entities were gradually giving way 
to the American. As Taboada states, "en la amplia literatura sobre los "orígenes Americanos" que tanto preocuparon a la Colonia, los moros están casi del todo ausentes" ("in the broad literature about 'American origins' that was so important for the Colony, the Moors are almost completely absent"; 131). As such, in Sor Juana's works the Orient per se appears only in conjunction with Biblical references. However, as Kushigian notes, her poetry "is purely mystical and greatly influenced also, either directly by Arabic-Spanish mystics or indirectly by the writings of Raimundo Lulio," whose ambivalent interest in Muslim mysticism became a source of inspiration for later authors (Orientalism 4). She further traces the roots of Sor Juana's Orientalism to the Medieval Peninsular tradition, comparing her to ulemas, the educated Muslim women in Andalusia and judias cultas, whose intellectual impact on society was significant (Sor Juana 176-77).

Octavio Paz in his study of Sor Juana's life and legacy also traces several Orientalist influences. He repeatedly argues for the association of Sor Juana's symbolic fertility with that of Isis, the Ancient Egyptian goddess of fertility, Paz declares that "la madre Juana es Isis, señora de las letras, y también la pitonisa que predice en su cueva (en su celda), encinta no de hijos sino de metáforas y tropos" ("Mother Juana is Isis, the lady of letters; she is also the pythoness who foretells in her cave (her cell), pregnant not with children but with metaphors and tropes"; Sor Juana 288). Paz also finds Oriental influence is Sor Juana's poetry of loving friendship. While in these poems Sor Juana oscillates between the expressions of courtly love (amor cortés) by the bard to his dame and the pledge of vassalage between the patron from his/her vassal, the very nature of the amor cortés, according to Paz, was undoubtedly determined by "la influencia de la 
erótica árabe. A su vez, ésta recoge y elabora la interpretación del platonismo hecha por los filósofos árabes helenizados y por los sufíes" ("the influence of Arabic eroticism, which subsequently retakes and elaborates on the interpretation of Platonism by Hellenized Arab philosophers and Sufis"; Sor Juana 264-65). As a result, Sor Juana's Orientalism is less direct than that of her predecessors. However, its metatextual character reveals a deeper interpenetration of the Christian and Muslim cultures as a result of their eight-century-long coexistence.

A close analysis of Sor Juana's references reveals the continuity of the process of reinterpretation of the traditional Orient and its historical role. However, the purpose of such reinterpretation in Sor Juana's works differs slightly from her predecessors', indicating a further development of Hispanic Orientalism. It is designed to complement the process of self-Orientalization initiated by the inclusion of the Colony into the European historic and cultural paradigm. The proper Orient that Sor Juana refers to in her text arises from the biblical texts. Both in her poetry and prose, it is Egypt and its history that are the center of attention. Her images of Egypt, especially the pyramids, can be attributed to the influence of Plutarch and Piero Valeriano, whose works became popular in the metropolis and also circulated in the colonies. However, as Rocío Olivares Zorrilla notes, these are images of "un Egipto idealizado y fantástico," in other words, Orientalized (“an idealized and fantastic Egypt”; 185).

As such, in Primero sueño, the comparison between the "barbarous" Egypt and the pious Christian world of her contemporaries is carried out on several levels (De la Cruz, Obra 190). Like in the mechanism used in Neptuno alegórico, Primero sueño demonstrates the positive impact of the development propitiated by Christian 
knowledge. Sor Juana, unlike the followers of Peninsular Orientalism, does not despise the Other. On the contrary, she highlights its achievements and glory, knowing that the higher it is in the eyes of the reader, the more dramatic will be its fall. ${ }^{96}$

The two worlds through have something in common, ${ }^{97}$ as "pirámides se juntan al Orbe" (De la Cruz, Obra 190). This represents the nexus that allows for them to communicate and for the new world to learn from its predecessor, much as the actual New World for Sor Juana becomes a better more progressive place after absorbing the Old World. But despite all the advances, the older civilization, as Egypt, "retrocedió cobarde" when faced with Christian world supremacy (De la Cruz, Obra 192). This parallelism based on both biblical tradition and Orientalist influence on Sor Juana reveal that she is following the interpretative path of Orientalization that her predecessor had successfully used to defend their theses and advance their thoughts.

Julia Kushigian indicated another interesting parallelism between Primero sueño and the general orientalism tradition. She points out that the topic of the nocturnal voyage, the circular nature and space of the poem and the limitless possibilities for perfection and imagination can be compared to the nocturnal voyage of the imagination in Thousand and One Nights (Sor Juana 180-81). This reinforces the thesis of Sor Juana's Orientalism as deeply rooted in the previous Hispanic tradition, significantly marked by the East-West dichotomy.

Like her early colonial predecessors, Sor Juana does not avoid the topic of the righteous power of the king that it linked closely to religion. Nor does she avoid the religious references, as the contraposition between the two worlds is carried out not only on the literal, but mostly on the symbolic level. The pyramidal form associated with 
Egypt, the symbol of its beliefs and self is opposed to the eternal circle, the symbol of Christianity. For Sor Juana, the "Pirámides fueron materiales;" they have "céntrico punto donde recta tira / la línea, si ya no circunferencia, / que contiene, infinita, toda esencia" ("Pyramids were material"; "center point, through which passes the line that is different from an infinite circumference that contains the essence of everything"; Obra 191). At the same time, its "bárbaros jeroglíficos de ciego" ("barbarous hieroglyphs of the blind"; De la Cruz, Obra 190), a means to convey the invisible God, as Sor Juana also suggests in Neptuno alegórico (Obra 777), lead to the collapse of not only Egyptian society, but also its soul. Even the same word "alma" ("soul") is used differently when referring to the two worlds, with a capital letter in case of the new more advanced world and written in lower case when referring to the old (De la Cruz, Obra 190-91). ${ }^{98}$

This picture of religious, cultural and historical decline is reinforced by the examples of other cases of the Orient's fall, such as the "blasfema altiva Torre" ("arrogant blasphemous Tower"), an indirect reference to the Tower of Babel, of whose futile existence "dolorosas son señales" ("the signs are so painful”; De la Cruz, Obra 191). These are opposed to the world, defined by Sor Juana as "maravilloso," the world that embraces Christianity and knowledge (De la Cruz, Obra 191). It is curious that this is exactly the same word that the previous chroniclers and religious men used when describing the New World and comparing it to the Old, hence, reinforcing the continuity of Sor Juana's Orientalism. The word "maravilloso" and its derivatives is a constant in the semantic field that describes the New World (for example, in Primero sueño it is used multiple times, see 191, 195, 199, etc.). In Neptuno alegórico it is not only the repetition of the word that is symbolic, but also the conclusion of the poet: 
Así, excelso Señor, claro Neptuno,

en el paterno amparo y oportuno

vuestro, la tantos años esperada

perfección deseada,

libra la soberana en cuanto brilla

Imperial Mejicana maravilla ... (De la Cruz, Obra 810)

This brings the parallelism of the use of this word to a new level: its meaning has changed from marvelous as unknown and unexpected, as in the early colonial writings, to marvelous as prodigy, something in which to take pride. Hence, Sor Juana not only successfully incorporates the New World through self-Orientalization into world history, but also lays grounds for the future development for this self-sufficient and valid in itself entity through the differentiation from the others and further elaborating on its uniqueness. The omens of the future can be seen in Sor Juana's description of her contemporary Mexico, "pobre en sus acciones" but "de deseos rica" ("poor in her actions"; "rich in her desires"; Obra 810). The poet culminates Neptuno alegórico praising "vuestra grandeza" that cannot but evoke La grandeza Mexicana (1604), the elaborate tribute to Mexican history and culture by Bernardo Balbuena ("your grandeur"; Obra 810).

In Neptuno alegórico, the contraposition between Old and New Worlds reaches its peak. The Orientalist mechanisms observed earlier are only reinforced by the direct juxtaposition of the Orient and contemporary Christianity presented earlier in the text, and the contraposition of the "Nuevo Mundo" and the metropolis: 
Éste pues, que aunque de altivo

goza tantos atributos,

hasta estar a vuestras plantas

no mereció el grado sumo,

la Metrópoli Imperial

os consagra por preludio

de lo que en servicio vuestro

piensa obrar el amor suyo,

con su sagrado Pastor,

a cuyos silbos y a cuyo

cayado, humilde rebaño

obedece Nuevo Mundo ... (De la Cruz, Obra 805)

Sor Juana's claims sound almost revolutionary, premonitory of the independence movement and showcasing the new phase of Hispanic Orientalism that strives to attest to the originality of the New World in its differentiation from the other civilizations. At the same time, in glorifying Mexico, Sor Juana shows respect to its deep connections to the European self, thus, undergoing the process of self-Orientalization. In the poem "Letra con que se coronó el festejo de esta asistencia" ("Bailes y tonos provinciales"), she notes:

... naciendo en Europa, pasó su luz matutina, 
brillando Estrella en Italia, a lucir Sol en las Indias. (Obra 89)

(“. . . being born in Europe, she passed her morning light as a bright Star in Italy and as Sun in the Indies"). However, Sor Juana does not have illusions as to when the New World will receive its recognition. As in the previous texts, she hopes that the Colony will someday attest to its marvel, but now "ya que no pueden con voces, / con el silencio lo explican" ("since they cannot do it aloud, they will explain it by silence"; Obra 89). This oscillation between the desire to be recognized as equal to Europe and to differentiate the Colony that prides itself in its uniqueness are characteristic of Sor Juana's Orientalism and is the precursor of post-colonial Hispanic Orientalism. Claudia Parodi who analyses the antagonistic processes of Hispanization of the Americas and the Indianization of the Colonial hegemonic society points out that Sor Juana often Indianizes, in other words, reinterprets the classical history for the purpose of glorifying the Colony (39). She singles out the epigram that uses the story of the Athena and Neptune who competed for the honor to name the capital city: "Si tamen hic certas: Neptunia Mexicus audit, / Neptuno, et Palmam nostra Lacuna refert" ("Yet, if you compete here, listen the Neptunia Mexico, our Lagoon gives the Palm to Neptune"; De la Cruz, Obra 799). This assertion, that if the battle took place in Mexico, Neptune would be the winner, brings this city to the same level as Athens (Parodi 39-40). At the same time, while Mexico is seen as equally important to Athens, it prides itself in its difference.

The Orientalism of Sor Juana, caught between the reinterpretative selfOrientalization and differentiation, such as is found in Primero sueño and Neptuno 
alegórico, can also be observed in the other poems. Although such instances are few, some of them also cast light on the nature of her Orientalist approach. Many of them, like the "Villancicos" of the "Primero nocturno" and "Segundo nocturno" (Santa Catarina, 1691) recur to the image of Egypt and the Nile that is reinterpreted through the Christian biblical tradition for the purpose of reflecting on the contemporary Christian world. Sor Juana skillfully uses these images to review the pivotal topics of her poetic career: the role of knowledge, the position of woman and the role of religion in contemporary society. The reinterpretation of the Orient plays a crucial role in this process.

Finally, there is a small number of poems where Sor Juana's self-Orientalization acquires a new dimension. While the previously analyzed works referred to the Colony as a sole entity, these poems show the ethnographic interest of Sor Juana who introduces to the reader the main groups (or later, castes) of colonial Mexico: Los Criollos, Los Blancos, Los Negros, Los Indios, etc. Similarly to the religious men (see Chapter 2), Sor Juana tries to recreate their image, mostly through their speech. It is curious that, unlike her predecessors, she not only showcases the semantic differences, but also phonetic and grammatical idiosincracies, something that became of interested to the friars only later in the colonial period.

Sor Juana's representation of the different layers of Mexican society seems to be coming from the point of view of the insider, not as much from the outsider that tried to mimic and blend into the society. Not only do her ceremonial verses usually adopt the position of the insider rather than the perspective of the metropolis, as indicated by George Thomas (38), but her other, less solemn works also follow this approach. That is 
why the Orientalization of the characters is carried out through their speech and is more tacit, as it appears to come from themselves. Some of the poems not only include the linguistic observations of Sor Juana, but also mimic the rhythms of Indigenous and African Languages, forming the "rhythm of the oppressed" (Miles 16-17). This allows the poet to address and represent a wider audience "with clear American character, distinct from the Spanish European tradition” (M. González 145).

As such, in the "Villancico VIII. - Ensaladilla," (San Pedro Nolasco, 1677) the Negro complains:

La otra noche con mi conga turo sin durmí pensaba, que no quiele gente plieta, como eya so gente branca. (De la Cruz, Obra 223)

('The other night with my conga I couldn't sleep and I was thinking hard that the Black people do not like the White people"). This passage not only highlight the phonotypical differentiations between the hegemonic and the subaltern groups, but also reveals the internal conflict voiced by the group that, as it was pointed out earlier, was condemned to silence (De la Cruz, Obra 89). The words of the Negro are preceded by a chorus "escrava no quede" ("don't become a slave") that are indicative of the social position of the signer (De la Cruz, Obra 223). This desire to give voice to the silenced echoes the intents of the religious predecessors of Sor Juana, like Fray Bernardino de Sahagún, who tried to approach the Other from positions different from the ones of the Hegemonic elite. 
Even more indicative of the latter is the representation of the Indio, who alternates the aboriginal language with Spanish, as well as his local traditions with Christian ones, as he says:

\author{
Sólo Dios Piltzintli \\ del Cielo bajó, \\ y nuestro tlatlácol \\ nos perdonó. (De la Cruz, Obra 224)
}

("Only our God Piltzintli came down from the Heaven and our tlatlácol gave us pardon"). However, and it is significant in the light of the previous Orientalist tradition, that the Indio also draws the following comparison:

\author{
"Téhuatl so persona \\ dis que se quedó \\ con los perro Moro \\ impan ce occasion. (De la Cruz, Obra 224)
}

("Téhuatl is the person who, they say, remained with the doggish Moors on impan ce occasion"). This reference that uses the typical negative adjective, applied to the Moors during the late Reconquest and the vestiges of which can be seen in the chronicles of the conquest and discovery, like the dog-headed people in Columbus's Diary, along with the images like the one of the Synagogue in El divino narciso, reveal the close connections of the Hispanic and Peninsular Orientalist tradition in the seventeenth century. And once again, as in the previously analyzed works, the Orientalization of the Other and the self served the purpose of self-definition for the greater purpose of differentiating, as Sor Juana states in "Loa para el auto sacramental de "El divino narciso"" "Dos Mundos," so 
that one day the Colony can overthrow "los Reales Pies / . . cuyas soberanas plantas / besan humildes las Indias" ("two worlds"; "the royal feet . . whose sovereign feet / the Indies humbly kiss"; De la Cruz, Obra 390; De la Cruz, Selected 87).

Another significant poem, "Villancico VIII. - Ensaladilla," (Asunción, 1681) can be seen as a precursor of what will be known in Mexico as castas paintings and portrays the social segregation as a result of deeply rooted Orientalist practices that reinterpret the subaltern societal groups by ascribing them certain pejorative characteristics. In the poem, Sor Juana singles out several of such groups: Los Negros, Los Mestizos, Los Galleguiños, and Las Mulatas. It is indicative that the White people, Los Blancos, are never mentioned in the poem; however, the other groups are inadvertently compared to them and judged by their principles. The principle of blood purity is manifested in the following words: "ha de ser todo blanco / y nada negro" ("everything has to be white, and nothing should be black"; De la Cruz, Obra 348).

The members of different castes are represented not only with their typical attributes, but are surrounded by the stereotypes that were the results of the previous Orientalization. As such, Los Negros are signing, Los Mestizos are portrayed as mentally inferior, as they "no entienden / tanto Misterio" ("Do not understand the Mysteries [of God]"; De la Cruz, Obra 348). It is curious the case of Las Mulatas (and the gender here is also indicative), as their Orientalization seems to go back to the original Peninsular Orientalism. There are even described as Orientals, similar to the descriptions of the Indigenous population found in the first chronicles of discovery. They have "rostro alazán/ algo tostado" and "de color de la pasa / traen tocado," the colors and the use of Arabisms (alazán) creating the appropriate Oriental entourage ("their face the color of 
cinnamon slightly burnt"; "they wear a headscarf of the color of raisins"; De la Cruz, Obra 348-49). However, despite the apparent step back to the Peninsular Orientalism, Sor Juana, as we saw earlier, seems to distance herself from the judgmental approach of her predecessors and to portray the castes more as an observer than a part of the hegemonic class.

In conclusion, the seventeenth-century works of Sor Juana reveal two growing tendencies in Hispanic Orientalism. She continues the tradition of the reinterpretative Orientalism. Like her predecessors, she shows ethnographic interest in the Amerindian Other. However, unlike those before her, she portrays them from the point of view of the insider. The Oriental Other serves Sor Juana as a tool to assert the predominance of the Catholic Church and European tradition, much like her predecessors. She reinterprets the Oriental Other in order to prove the superiority of the current civilization over the ancient, and with it, to showcase the importance of the Colony for world history, balancing between its uniqueness and its relevance to world history.

On the other hand, the Colony in Sor Juana's narrative undergoes a process of self-Orientalization in order to occupy an equally important place in a predominantly European history and imagery. This moment is crucial for late colonial Orientalism, as it consequently allows for a process of differentiation --first from the Oriental Other, then from Europe, and later, from others-- which results in the independence of the Americas. Being a self-sufficient and equally important entity are the most important conditions that would allow for this to happen, since the role of a subdued Other would not prove the legitimacy of striving for independence. Paraphrasing the words of Stephanie 
Merrim, Sor Juana orientalista "pieced together her own world" (231), whose fragile equilibrium she tried to preserve in her works.

\section{$\S$ 3. Orientalization through Segregation in the Castas Paintings of the Eighteenth Century}

The racial diversity in the New World, enhanced by the interracial relationship posed a destabilizing threat to the social structure of the colony. Despite the wide variety of the racial mixtures in the Colony, towards the beginning of the nineteenth century, the demographic map of the Hispano-American population was approximately, the following: $40 \%$ - black, Mestizo, Mulatto and other mixed groups, $40 \%$ - indigenous population, and 20\% - white (Tuñón de Lara 375-76). These three groups existed in the New World in constant opposition to each other, which led to their segregation on all levels, civil and religious. ${ }^{99}$ As Nicolás León describes it, "de las tres razas, una mandaba, la otra obedecía, y la tercera estaba en una servidumbre de derecho" ("among the three races, one dominated, the other one obeyed, and the third one was a part of lawful slavery"; 7). The dominance of the "blanco" ("White") led to the gradual Orientalization of the other two, the "indio" and the "negro" ("Indian" and "Black"), as seen in the previous chapter.

However, in the late colonial period the hegemonic group, in the absence of an

immediate local threat, becomes more and more heterogeneous. ${ }^{100}$ The concept of purity of blood, inherited by the colonizers from the period of the Reconquest, continues playing an important role in the late colonial period. While the opposition "gente 
blanca" / "gente de color" and "gente con razón" (Whites and Mestizo) / "gente sin razón" is crucial for the social hierarchy, there is a segregation tendency among the very colonizers ("white people - colored people"; "rational people- irrational people"; León $8,27)$. And, curiously, it is based on the degree of interference of the both Amerindian Other and Reconquest Other (Moors and Jews). On one hand, "los blancos . . eran todos limpios; la mancha que en su sangre pudiera encontrarse para la sociedad, solo podia provenir de los delitos que traía consigo la infamia, de tener mezcla de moro o de judío, de haber sido penitenciado por la inquisición" ("The Whites were all pure; the only defect that they could possess in the eyes of the society was the result of the disgrace: having Moorish or Jewish blood or having been sentenced by the Inquisition"; León 8). The distinction between the inhabitants of the colonies was based on the principle of raza, coined during the period of the Reconquest. The notion of raza, as Magali Carrera notes, "connoted generational associations with Jews and Moors and was used in Spain as a means to legitimize the discrimination and persecution of the nonChristians and their descendants (10). As a result, the basic principle of the relationship between the layers of the society or castes was imported from the metropolis with all its Orientalist attributes.

On the other hand, and it is crucial for the nature of the relationship with the self and the Other in the Americas, not all the members of the "white" group in the Colony were pure descendants of the Europeans. Some of them had indigenous blood. Even though this presence could be minimal, it automatically displaces such individuals from the hegemonic position in society. Similar attitudes towards one's own heritage led to the idea of blanquemiento or mejoración de la raza ("whitening" or "race 
improvement"), which imposed on the Other the desire to be associated with the colonizer by his appearance, language, and social status. In this case, the Other would not only accept his lower position, compared to the European, but also Orientalize himself and try to mimic the colonizer in order to solve this self-imposed dilemma.

Finally, there was a rivalry between the newly arrived Spaniards, contemptuously called gachipunes (cachupines), and the lineages of the original conquistadors and explorers of the New World. The differentiation between these two groups was not as radical as in the cases of others, so anything would serve to point out their lack of relevance for the top social class, like in this popular lyrics widely spread in New Spain:

Gachu en arábigo hablar

Es en castellano Mula

Y Pin en guineo articula

Acá en nuestro idioma dar;

De donde vengo a sacar

Que el nombre de Gachupin

Es un Muladar en fin

Donde el Criollo siendo Culo

Podrá con gran disimulo

Cagar en cosa tan ruín. (sic). León 18

What Gachu is in Arabic

Is Mula in Castile 
And what Pin is in Manila

Dar in our language is,

So, the conclusion is deep:

That Gachupin is a Dung Heap;

While the Criollo is a Behind,

So one wouldn't really mind

To shit on such thing without guilt.

As it can be seen, the criollos, Spaniards born in the colony, had a similar fate. ${ }^{101}$ León in his analysis of the caste system in colonial Mexico suggests that this denomination is an "americanismo," but at the same time he indicates a more Orientalist explanation, which would point to the not-so-pure origin of this group. According to Mexicanismos by Fray Pedro Simón, “criollo es vocablo de negros, y quiere decir persona nacida en la tierra, y no venida de otra parte" ("Criollo is a Negro word that mean a person born in the land and not coming from somewhere else"; qtd. in León 19). The relationships between different categories of whites in the colony were conflictive, eventually igniting the independentista movement.

This differentiation in hegemonic society is indicative of the vectors of Orientalization in the transitional period of the formation of the Hispanic Orientalist paradigm that took place in the late colony and during the early independence. As Latin American nations were moving towards their independence, there was a strong need for differentiation. In the early colonial period, the crucial point for this differentiation was the Amerindian Other. However, towards the $19^{\text {th }}$ century, the differentiation from Europe, the old colonizer, became indispensable for the creation of independent nations. 
Yet, the prolonged contact between colonizer and colonized could not but influence the perception of hegemonic society, following Browne's thesis that "through mimesis, human beings make the Other ... their own" (166).

The attempts to create "an impression of the society that is orderly, stable, and clearly defined" led to the appearance of the so-called cuadros de castas or castas paintings. According to the Franciscan friar Juan de Torquemada, they represented "variedad de colores" ("variety of colors") in the colony; through, their apparent order and tranquility are a "carefully arranged illusion" (Guzauskyte 176). Curiously, these paintings originally were not meant to place emphasis on cultural diversity, but rather to glorify the colonial pride of the criollos. As the metropolis was distancing itself from the colonies, the criollo elite became increasingly interested in their immediate surroundings. This, combined with the not-so-friendly relationship with the Spaniards, led to a strong link, as Katzew argues, between castas paintings and criollismo to the point that the latter was fundamental for their appearance (1-2).

Taboada reveals a remarkable assimilation by the criollo chroniclers of the Andalusian world that led to "la reaparición americana de una toponimia reconquistadora o pasajes donde los españoles se comparan a sí mismos con los héroes de la Reconquista" ("resurfacing in America of the Reconquest toponymy, where the Spaniards compare themselves to the heroes of the Reconquest"; 192). In the chronicles, this mechanism served to differentiate between hegemonic society and the settlers, elevating the roles of the former and reinterpreting the image of the latter. The castas paintings used a similar mechanism to implement the mechanism of racial and social differentiation by the way the castes were portrayed. Their violent or non-violent 
behavior, exotic environment, typical occupation - all of this, reflected in the paintings, served as an anthropological landscape, the tacit reference which was Spain and the white Spaniard. The popularity of such images arose as a result of the centuries-long Orientalization of the Amerindian and African Other in the New World, rooted in the mentality of the early colonial period in Latin America.

In order to understand the social and racial complexity of the New World, as well as the fertile grounds where Hispanic Orientalism set roots, it is important to determine the function that castas paintings had in the life of the colony. There is an argument about the functionality of the paintings that is closely related to their Orientalism. Anthropologists like Francisco de las Barras de Aragón (1929) argue for the presence of a great degree of realism in the castas paintings due to the scientific curiosity typical of the Enlightenment. On the other hand, a more contemporary theory by Concepción García Sáiz argues for a certain level of exoticism. Finally, the most recent studies of Ilona Katzew and Estrada de Guerlero emphasize "the degree of artifice present in the genre" (Katzew 6-9). In this light, if the reality portrayed in the castas paintings was deliberately manipulated, they represent a perfect example of Orientalist approach, much like the chronicles of the conquest. The reinterpreted reality here, however, served not only for the purpose of appropriation. Given that criollismo served to promote this genre, it was also intended for differentiation purposes. Yet, it is important to note that this pursuit of differentiation was still in its initial stages.

Ultimately, as an Orientalized portrayal of colonial reality, castas paintings served as a reflection of the desire of hegemonic society - itself heterogeneous - to stabilize colonial society by ascribing each group a role and, along with it, a certain 
Orientalized image designed to make the new castes fit into the prevailing social hierarchy. This pictorial genre voiced the prejudice the dominant class had towards the Other(s). In this sense, it is consistent with the depiction of violence in castas painting. Evelina Guzauskyte points out twenty four paintings, which reveal that, in the eyes of hegemonic society, mixing with the Other, especially with those of African descent, only meant el empeoramiento de la raza ("worsening of the race"). Among these, "three paintings portray unions between individuals having some proportion of Spanish and Indian blood, and only two depict Black African and Indian relationships, while nine paintings show Black African and Spanish unions. The latter focuses, however, on gender, not on racial differences" (179). This is significant, as it proves that the process of racial mixing not only negatively affected the population, but even violated the traditional role of women, who become disobedient and even violent. It reflected the concern of the contemporaries about the wide-spread moral decay in the colony (Lehman 125), something that can be seen already in the later chronicles of the conquest. All in all, as Pierce notes, "casta sets advertised the natural abundance, in both products and people, of the American territories and exhibited a new sense of chauvinism and pride about the wealth of the Americas" (53). However, such images "inevitably apprehended European cultural features according to the internally determined parameters of their own dispositions" (Browne 167).

The castas painting represent the gradual development of the process of mestizaje ("racial mixtures") in the Americas, which led to the imminent desire on the part of the local upper class to redraw and reestablish their hegemony in the Colony. According to Nicolás León, there were fifty five different groups that represented 
various degrees of racial mixture (some castes out of the fifty five can be seen as synonymic denominations of the same caste) (21-27). ${ }^{102}$ Bonnie Gasior notes a curious and significant fact about these groups: ${ }^{103}$ thirty of them referred to the mixtures with Africans (1:245). It is interesting to note the obsession of the colonizer for depicting all the minutest racial differences that eventually define social and cultural barriers. Such groups depicted all the possible racial mixtures in several generations, which could point to a strong need on the part of the ruling class to establish a new type of hierarchy in the Colony.

Most of such groups had pejorative names, which indicated their lower, subdued position, compared to the dominant white race and even other "pure" races: for example, Saltarás for a darker offspring ("Jump back"), No te entiendo ("I-don't-understandyou") or Mulato ("Mulatto" derived from "mule"). In this sense, the castas paintings represent an popular source of information about racial mixtures in the Colony, and at the same time, an illustration of the mechanisms of migration of the original paradigm of Hispanic Orientalism to the New World. It is frequently argued that these derogatory names were often "fanciful inventions created by a few intellectuals and the artists of casta paintings" (Katzew 44). While this can be indicative of the fact that these names were not as common among the non-elite population. It shows that the vector of Orientalization proceeded, as usual, from hegemonic society, which created an Orientalized image of the subedits that the latter did not necessarily shared.

The castas paintings originated in colonial Mexico and became very popular toward the end of the eighteenth century. ${ }^{104}$ This type of art was especially popular in the Viceroyalty of New Spain; however, similar paintings were produced as well in the 
Southern Cone (modern Peru, Ecuador, and Bolivia) (Guzauskyte 177). Often, the series were ordered by the metropolis, and were perceived as a type of souvenir, which resulted in creating of a large number of such paintings. This suggests that castas paintings were successfully used in the New World as a vehicle to promote social and racial differences among different groups that formed during the conquest and exploration of the Americas.

The castas paintings, as most early colonial art, was an heir to European artistic traditions and trends, while at the same time developing its own distinguishable and unique style. Asian influence, as a result of the ongoing trade via the Manila galleons, was prominent in eighteenth-century Mexico, where a burgeoning nationalistic sentiment resulted, among other things, in this type of human cataloguing (Pierce 48, 5657). This aspect of the paintings is significant in the light of the Orientalizing nature of this type of art.

A very important aspect of castes, represented in the castas paintings, is the notion of "calidad" (quality) as a means for mimicry, ambiguity, and hybridity, as suggested by Magali Carrera (6-15). ${ }^{105}$ It was widely believed that the mixture of races resulted in quality degradation (with few exceptions, such as the offspring of Spaniard and Castiza, who would be considered a Spaniard). In this sense, the product of racial mixtures in the New World can be compared to the offsprings of Jews, Christians, and Arabs in the fifteenth-century Spain, whom premier grammarian Antonio Nebrija considered of "sangre corrompida" ("corrupted blood") (qtd. in Guzauskyte 181). This parallel is especially important in the transition of Hispanic Orientalism, as it 
contributed to a similar perception of the Other in the Americas and its association with the Other in Medieval and Renaissance Iberia.

Since, the castas paintings represent an attempt to categorize the diverse racial mixtures originated from the three dominant races in the New World: Europeans (Peninsular Spaniards), Indians (Native Americans) and Blacks (Africans), they are often painted in series of twelve or fourteen and depict a mother, a father, and their child; as well as show the daily life in the colony, representing the clothing, typical for the caste, fauna and flora, etc. (Sullivan 86). Over a hundred castas paintings sets are known to exist and more continue to surface (Deans-Smith 169). Castas paintings, in a way, are similar to Spanish "cuadros de costumbres" or depiction of manners (a part of the costumbrismo movement) and can serve as an encyclopedia of the everyday life of the period. The decline of the castas paintings is often associated with the independence movement in Mexico and the search for national identity (Carrera 136-37). As a matter of fact, the nineteenth-century political changes in Mexico resulted in the prohibition of castas paintings in September 1822 and the declaration of the equality of the citizens before the law, stated in the Constitution of 1824 (Ladd 122). These reforms aimed to establish a new national identity, dramatically different from the colonial subject.

The depiction of the all possible outcomes of miscegenation in the colony, as Wendy Phillips points out, is to "acknowledge and document the presence of Africans and of Europeans and indigenous groups as the roots of . . mestizaje, or cultural blending" (775). While the white population was atop, the indigenous people and the people of African descent ${ }^{106}$ were not treated equally. Indians were associated with unskilled labor and agriculture, while Africans were perceived as a rather homogenous 
sector of society that did not have any rights. The alliance of Indians and Africans and their potential revolt was feared by the ruling class, which was amply outnumbered (Katzew 39-41).

Of especial interest for the study of Orientalism is a group that gained significant presence by the seventeenth century and was mentioned in many official writings well into the eighteenth century. These are the ladinos, the westernized, mostly mestizo, locals who broke with their customary ways of life and adopted Spanish manners (Katzew 41). While there is no documented presence or influence of the Jewish community on Latin American ladinos, it is remarkable that this term, denominating the Hebraic-Spanish language of the Sephardic community (which in itself is a corrupted version latino), was used to denominate the cultural converts of the Americas.

The castas paintings portray a colonial diversity that goes beyond the three main races. Several of these groups exemplify the Orientalist tendencies regnant in the New World during its transition from the colony to the independence. These are the groups, whose treatment by the hegemonic society denotes an Orientalist-like approach to the representatives of the caste. In the chronicles of the previous centuries, as it was seen previously, the prominent and active Oriental reference was gradually disappearing. However, it is important to note, as Taboada points out, that while the direct identification with the Orient disappeared rather fast, the process of association of Amerindians and Muslims did not have the same fate because of certain more or less unconscious attributes ascribed to either of these Others (Taboada 221-22). There is much evidence of this in the folkloric and linguistic heritage: expressions like moros en la costa (Moors on the shore), games like juegos de moros y cristianos in Spain and 
gioste del Sarracino in Italy (Majid x, 162-66), words used to denominate maíz ("corn"): "minho marroco," "millo mouro," "grano de Turquía," "blé sarrazin," "arabósitos," or "frumento turchesco" (Taboada 222). The relative abundance of Orient-related caste names in the colony is another example of the persistence of Reconquest-type imagery in Latin America, as the mindset of the participants continued well after 1492 both in the Peninsula and in the colonies.

In this light, of special interest for this study are the castes of Albarazados (or, in other transcriptions, Albarasado, Alvarasado or even Albarrasado), Barzinos (or Barcino, Barnocino or Varsino), Chinos ("Chinese"), Moriscos ("Moresque"), and Genizaros ("Janissaries") and other groups that derive from them. These groups are referred to as mano prieta (dark hand), which distinguishes them from the whites and Indians ${ }^{107}$ (Katzew 42). Their image, the denomination of the caste, and the peculiar characteristics related to their appearance shed light on the development of Hispanic Orientalism in the late colonial period.

The above mentioned castes can be divided into two groups based on their name. The first group contains the Albarazado and the Barcino, whose names may have derived from Arabisms in Spanish. However, according to the Dictionary of the Royal Academy of the Spanish Language, only the name of the first group is indeed rooted in the Arabic word albarás, meaning a very white, very pale skin, which can be used derogatively ( $\underline{\mathrm{RAE}})$. This caste that represented the seventh generation of SpanishAfrican descent did not constitute one of the basic categories. However, by the end of the eighteenth century it became much more popular among the castes painters (Carrera 53). Barcino, defined as "dicho de ciertos animales, especialmente de perros, toros y 
vacas: de pelo blanco y pardo, y a veces rojizo," is of unclear origin ("said about certain animals, especially dogs, bulls and cows: of white, brown and sometimes reddish color"; $\underline{\mathrm{RAE}})$. León, citing Diccionario de la Lengua Castellana, traces the root of the word to Arabic baraxa, a spot on horse's skin (21).

However, what is important in the case of these two groups is the fact that hegemonic society chose these names that can potentially be traced to the language of the traditional Other and kept the derogatory meaning that was typical for the denominations of the other castes. This tactic, the expansive use of Arabisms to describe the reality of the New World and convey the perception of the new phenomena, was typical for the early colonial period, where the Amerindian Other was reinvented, and indeed reinterpreted, in order to be included in the social hierarchy. The Albarazado and the Barcino share a similar fate, which can be explained by the strong presence of Indian blood in these castes. As a matter of fact, the Indian blood is dominant in both groups. ${ }^{108}$ Their representation was rather popular in the castas painting series, which allowed for the persistency of their Orientalization in Mexican Yucatec folklore. ${ }^{109}$

However, a greater interest accompanies the second group of castes, represented by the Chinos, the Moriscos, and the Genizaros (Chinese, Moors, and Janissaries,). Despite the apparent referral to people of Chinese and Moorish origin or the military men serving the Ottomans, these names refer to the local hybrid castes and lack any direct connection to Oriental cultures. These groups become indicative of the vector of Orientalization that is being established in the late colonial period. All of them share a common denominator: they are not directly associated with the non-American Other, which means that their image is rather the result of reinterpretation based on the vague, 
mostly phenotypical similarities between the groups; rather than of reinvention, which was typical for the early colonial period, when the general lack of information contributed to the wide use of imagination by the first conquistadors and explorers.

Evidence for this hypothesis is the use of the images of the three castes by the artists. They differ in frequency of occurrence in the castas paitings and, therefore, in general popularity among the painters. Since the basis for their Orientalization was reinterpretation, hence, this preference would depend on the public's familiarity with the subject of comparison. And indeed, a significant difference can be observed here: ${ }^{110}$ the representations of some of the castes are not as popular as the others. In order to establish the reason for this and reveal the nature of Orientalization in its transition from the colonial to an independentista paradigm, it is crucial to look into the components of the racial mixtures denominated as the Chinos, the Moriscos, and the Genizaros, and their links to the original Others they seem to evoke.

Based on the catalogues analyzed, as well as the castas painting series, exhibited nowadays both in Mexico, Spain, and the Unites States, it was established that the most popular group among the three Orientalist castes was the Moriscos. According to Ilona Katzew, the caste name morisco appeared in the seventeenth century, along with castizo (44). They were also the group that was easiest to identify racially. ${ }^{111}$ In most of the castas paintings, the Morisco's ancestors are always the same: a Spaniard and a Mulatta (Mulatto being a mixture between Spaniard and African). ${ }^{112}$ Hence, the similarities in phenotype of the Peninsular Moriscos and the new hybrid caste in Latin America allowed the colonizer to export the name and the connotations associated with it to the new territories. This original perception that the American continent was a part of Great 
Asia and the presence of Arabs and even Chinese was to be expected (it is not accidental that Columbus brought an Arabic interpreter with him), played a crucial role in the initial denomination, when the Orientalization process of appropriation of the Amerindian Other went through the path of reinvention. However, as the years went by, this denomination persisted, not as a direct association but as a comparison to the original Moriscos.

While the representations of the Moricos can be found in most of the castas paintings series, it is unusual that, unlike the others, in the painting Las castas from the Museo del Virreinato, Tepotzotlán, part 4 represents a slightly different variation, which sheds light on the roots of Latin American Orientalism. Its title, "Español con Mora Mulato," at first, introduces the spectator to another type of racial mixture present in the Colony. However, the deeper meaning of this inscription, the quintessence of Peninsular Orientalism transported to Latin America during the early colonial period, can be seen only in comparison with the other similar castas paintings. As such, painting \# 4 of the castas paintings series of Miguel Cabrera (1763), Andrés de Islas (1774), and Francisco Clapera ${ }^{113}(1775)^{114}$ refers to Mulatto as a child of Spaniard and African. This reinforces the hypothesis that the transatlantic migration of the Peninsular Orientalist paradigm was natural. In the New World the colonizer found himself surrounded by, in his opinion, the same or similar ethnic groups that he had Orientalized previously in order to understand and fit them in the paradigm ${ }^{115}$ he was accustomed to.

Another group affected by transatlantic Orientalism are the Chinos. Unlike the Moriscos, this group does not represent a homogeneous entity and is described differently in the castas paintings. ${ }^{116}$ The Chinos constitute a very varied group, as it 
often refers to the offsprings of different castes of mixed blood. Also, unlike in the case of the Moriscos and the Genizaros, there are several variations of this caste, such as for example Chino Cambujo and Cuarterón de Chino. If one takes into consideration the representations of the Chinos in the castes paintings, it is difficult to establish a clear general racial pattern: in some of them African or Indian blood predominated (Clapera, Cabrera); in others, it was Spanish blood (see the painting from Museo de Virreinato unlike in the pattern suggested by León, in others, Indian (Islas). However, this racial mixture with the (strong) presence of Latin American Indio and African Black is the feature that they have in common.

Hence, the Orientalization path of these groups, rooted in physical appearance, is similar to that of the Moriscos. The name of the caste - the Chinos - is also indicative of the Orientalization path that was typical of the Colony, itself deeply rooted in the syncretism of the actual Orient and the supposed Orient (the Americas) imposed by the colonizer upon the colonized and persisting in popular memory even after America was proven to be a different continent. As such, the word Chino (Chinese in Spanish), referred not only to the phenotype of the person, but also indicated his/her occupation, as it became associated with the Quechua word china, a "servant girl of Indian or Mestizo blood" (García Sáiz 26). It can also arise from the commonplace denomination of the inhabitants of the Philippines as chinos (León 69). This process of merging the Orientalized subjects will be rather common in the early colonial period. ${ }^{117}$ The fact that such denominations persisted shows the impact that traditional Peninsular Orientalism had on the Americas. However, this original Amerindian orientalism is gradually losing 
its fairytale-like nature, turning into reinterpretation, as demonstrated by the numerous attempts of looking for the local origins of the Chinos.

The origin of the third group, the Genízaros, in contrast with Moriscos and even Chinos, is rather obscure. Unlike others, the Genizaros are not regularly depicted in the castas paintings. In the collections mentioned by León, there is only one depiction of the Genizaro, and in the other works analyzed, they are mentioned only by Francisco Clapera in \# 15 (De Genizaro, y Mulata Gibaro) and \# 14 (De China, e Indio, Genizaro), both of 1775, and by Ignacio María Barreda y Ordóñez in \# 13 (De chino y genizara, albarazado, 1777), hence, leaving their social status and relations to the other groups unclear. ${ }^{118}$

The name of the groups, which derives from the Turkish word yeni-çeri ("new, inexperienced military force, new troops"), refers to another commonly-encountered Other of Europe, the Ottoman Empire, hence linking this group directly to the Orient (Armstrong 130). Europe at the time was very familiar with Janissaries, who emerged as a group in the fourteenth century and since then actively participated in the Ottoman military campaigns. These elite soldiers were selected from the population of the conquered lands, following the law of draft, devshirme, also known in Europe as "Law of Tribute Children" (Kinross 147). The Janissaries were Christian-born ${ }^{119}$ and unlike general non-Muslim subjects, such as Greeks or Slavs, were forced to convert to Islam (Kinross 58-59). This hybrid nature of the Oriental subject, converted into the Other and then reshaped to fit dominant society by the Orient itself, approximates the situation of the Genizaro group in the Americas. Drawing a conclusion from the paintings representing the Genizaro groups, these were the product of mixture of European, 
African, and Indian bloods, with a predominance of the latter. Nevertheless, the fact that such name, referring to Turkish warriors, was used to denominate a caste in the Colony reaffirms the hypothesis about the development of the original paradigm of Hispanic Orientalism in the Colony towards a more interpretative approach.

In conclusion, the castas paintings reflect the results of the social processes that originated in the early colonial period. Their creation was the culmination of the attempt by hegemonic society to bring stability to the multiracial world created in the Colony. However, as a result, this society "marchó de la hibridez al casticismo, en una evolución empobrecedora que le hizo perseguir toda huella que pudiera recordar la diferencia religiosa" ("in the process of an impoverishing revolution, it went from hybridity to caste system, making sure that even the smallest trace of religious difference would disappear"; Taboada 239-40).

Several of the castes reveal in their names and racial structure the path that Peninsular Orientalism took in America. While the initial selection of the name could be related to the Orientalist-like reinvention of the Other, the later pictorial endeavors aimed to clarify the origins of the castes like Chinos or Genizaros demonstrate that late colonial Orientalism was switching from a process of reinvention to one of reinterpretation of the Other. This indicated that the Europe/Asia dichotomy is gradually shifting towards America/Europe, which becomes characteristic of the transitional phase of Hispanic Orientalism.

The castas paintings, charged with hegemonic colonialism, became the predecessors of a series of postcards representing the American aboriginal population, which circulated well into the twentieth century. Despite the prohibition of pejorative 
castas representations, their orientalist legacy continued in Latin America. In his analysis of the postcards that were part of an exhibit by Guillermo Gómez-Peña and Coco Fusco, dedicated to the five hundredth anniversary of the discovery of America, Jorge Barrueto notes that similarly to castas paintings even nowadays, "esta representación étnica visual, presente en la tarjeta postal, refleja las ideas e intereses de las élites locales que dominan la nación, en donde los indios son sujetos sualternos en el escenario político nacional" ("this ethnic representation in the postcards reflects the ideas and interests of the local elites who dominate the nation where the Indians are subaltern subjects in the national political arena"; 47). Therefore, it is clear that the legacy of eighteenth-century Orientalist representations found its repercussion in the minds of the hegemonic social group that continues to use it for its political purposes.

\section{§ 4. Differentiation through Reinterpretation: The Gaucho and the Oriental in Sarmiento's Narrative}

Historically and politically, the late Colonial period in Latin America was a tumultuous and unstable period, when the constant power struggle was gradually reshaping the distribution of influence and powers in Colonial society. As seen previously, Hispanic Orientalism did not avoid this transition as well, oscillating between the Peninsular-indebted tradition of appropriation of the Other and the nascent attempt at differentiation for the sake of self-definition and taking pride in one's own newly found identity. The Independence movement and the struggles of the early postIndependence period ignited this process in the political as well as the literary arena. 
This section analyzes one of the fundamental post-Independence texts, Facundo: civilización y barbarie (1845), by Domingo Faustino Sarmiento (1811-1888), where the struggle for Argentinian independence forms a parallel with the clash of Orientalist traditions in Latin America, thus revealing the predominant tendency in Hispanic Orientalism in the newly liberated states of the New World.

Sarmiento was born into a new era; only a year after Argentina proclaimed its independence from Spain. However, the fight for independence started much earlier and culminated much later; and it was far from its end, as he himself noted, when Facundo was first published as a series in the Chilean journal El Progreso in 1845. The key to understanding Sarmiento's political position and, consequently, his approach to the Orient and the problem of the Other can be found in the deep political controversy that reigned both in the Colony and in the metropolis on the verge of the wake of the Independence movement in Latin America. On one hand, the exploitation of the New World was reaching new heights, as the continent watched the benefits slipping away from the Colony. For instance, in 1785, 3.5 million pesos in wealth were taken out from New Spain alone, and this figure rose to 6 million pesos during the mid-1790s (Haring $305)$.

The exploitation of the Colony was not only economic but also cultural. The undermining of the colonial self became a constant in the relationship between the colonizer and the colonized. As Covadonga Lamar Prieto states, "tres son los temas que vertebran la minusvaloración a lo americano durante la polémica del Nuevo Mundo: la desintegración física de todo lo criado en el Nuevo Continente, las escasas o evanescentes virtudes intelectuales de los criollos y, por último, la configuración política 
de la sociedad" ("there are three topics that are the foundation of the underestimation of everything American in the polemics of the New World: the physical disintegration of everything created in the New Continent, the scant and fleeting intellectual virtues of the criollos, and, finally, the political configuration of society"; 79). The criollos themselves, as the "product" of the Colony, were under a constant attack despite the significant demographic disparity between the European-born and Latin America-born white population of the Colony. For instance, by 1790, in the Intendancy of Mexico only $0.1 \%$ of the population were European-born, $2.2 \%$ in Mexico City (Carrera 39). The stronger and the more independent economically and politically the Colony became, the more its self-awareness grew and its desire to take pride in its difference from the metropolis, and later, from the world asd a whole. The Orientalist separation between the self and the Other became a perfect mechanism with which to carry out this task.

On the other hand, and contributing to the process of the awakening of the Colony, was the political crisis in the metropolis that affected its presence in and governance of the New World. Towards the beginning of the eighteenth century, the Bourbon monarchs in Spain launched significant reforms for the Colony. Started by Philip V (1700-1746) and reinforced and continued by Charles III (1759-1788) and Charles IV (1788-1808), they aimed to counteract the gradually increasing distance between the metropolis and the colony. Among those acts were increased taxation, restructuring of the colonial administrative system, decreasing the powers of the local laic and religious authorities (Katzew 112). However, the Napoleonic invasion interfered with the colonial plans of Spain, setting the grounds for the chain of revolutions that 
culminated in the independence of most of the Spanish colonies by the mid-eighteenth century.

The Independence process in Argentina began as a result of its economic empowerment. The independent Viceroyalty of La Plata with Buenos Aires as its capital was established in 1776-1777 as a result of its separation from the Peruvian viceroyalty. Its major consequence was that the elite could no longer exercise the artificial control of the commerce and trade flow (MacLachlan 99). In 1810 came the proclamation of the official separation from the metropolis; however, the process of the establishment of the new state took much longer, as the "Colonial government was no more arbitrary than that of the parent states, and no special forms of constitution were contrived for the American colonies. Each colonizing power automatically exported a simplified form of its own system of government and law" (Fieldhouse 97).

All of the above characteristics were part of the political climate of Argentina where Sarmiento grew up and where his political views as a member of the Generación de 1837 forced him into exile to Chile where he wrote Facundo. An analysis of the country in making, the text portrayed the duality of the former Colony: its oscillation between the past and the present, between the capital and the interior, civilization and barbarism, and ultimately between "us" and the "Other." This oscillation defines Sarmiento's approach to these two selves, as he "tries to establish a 'civilized' yet criollo identity (Civantos, Criollo 44). In the Orientalist tradition, he stays between the innovative tendency of differentiation of Sor Juana, whose poetry and prose are permeated by the desire to be included into European history but also reflect the nascent desire for independence, and the castas painting, deeply rooted in traditional Peninsular 
Orientalism that strived to reinvent the Other for the purpose of its domination. ${ }^{120}$ This duality of traditionalism and progress, civilization and barbarism, is what defines Sarmiento's Orientalism and what makes it more complex and less linear than that of his predecessors.

In order to understand it, it is important to define Sarmiento's position in relation to what he calls civilization and barbarism, both in his narrative and in his personal experiences: how he describes both and what delineates his Orientalist model. William Katra in his analysis of the impact of Sarmiento's travels to the world outside the former Spanish Colony depicted in his books, such as Viajes, notes that "his previous illusions about an exalted 'civilization' had been thoroughly shaken" after he saw the "abject misery of . . . the general population" (74). This disillusion about the world that was for centuries the model against which the Latin American Other was tested led to a profound change in Sarmiento's attitude towards the "civilized" and the "barbarous." Katra argues that this caused that "from start to finish Sarmiento was predisposed to embellish what he saw, for this New World vision provided a new justification for his class, and revitalized directions for his own energies" (74-75). Because of this new light, the revision of the traditional perception of the Other, rooted in the Peninsular Orientalist tradition was inevitable.

However, the image of the Other created by Sarmiento in his works, especially in Viajes that reflected his travels to North Africa, among other places, is sometimes criticized precisely because of its Orientalist cut. Isabel de Sena, for instance, argues: “SSarmiento ha visto Argelia? . . Porque en cierta forma ... nunca salió de su cuarto, el viaje de circunnavegación de Sarmiento es una extensa alegoría sobre un centro (la 
civilización e industria del Norte) y sus márgenes (los desiertos, literales o metafóricos, del Sur) y su búsqueda de medios para integrarlos" ("'Did Sarmiento see Algeria? Because in a sense, he never left his room, his circumnavigation is an extensive allegory about the center (the civilization and industry of the North) and its margins (the deserts, literal or metaphorical, of the South) and his search for a means to unite them"; 86). This casts light on the traditionalism of Sarmiento's use of Orientalist mechanisms that, as before, are manipulated for the purpose of achieving political goals.

Some researchers, such as Paul Verdevoye and Christina Civantos, establish an unexpected connection between Sarmiento and the Orient, pointing out his possible Oriental origins through his maternal ancestors and that the writer himself traces the origins of Albarracín, his maternal last name, to a Saracen leader of the twelfth century (Verdevoye 707; Civantos, Orientalism 27). On the other hand, Cristina Civantos in her extensive research on the Oriental, and in particular Arabic, influence in Facundo, highlights the connection between the gauchos and the Arabs via Spain, the motherland perceived by the Americas "both as España and as al-Andalus" (Orientalism 25-28). Indeed, the interconnectedness between these two Others, the Amerindian in the Colony and the Arabic in Spain, lays on the surface of the text.

There is a significant discussion among literary critics about the function of the Orient and Oriental references in Facundo. Some of them, such as Ana María Barrenechea, Jaime Concha or Carlos Altamirano, attribute the appearance of the Orient in Sarmiento's narrative to various aspects of romanticism (Civantos, Criollo 51). Indeed, these picturesque images of the Orient that evokes certain connotations and perceptions abound in romantic European literature (for instance, José de Espronceda in 
Spain, Lord Byron in England, Mikhail Lermontov in Russia, and others). Civantos notes, the Orient could have been used also for a different reason. While the gaucho was unknown to Europe, the Oriental Other was a common reference. Using it to describe an Argentine Other would make it easier for the European reader to absorb its image. However, "we could almost say that the gaucho and the Arab are equally unknown to him; certainly he visits Algeria before he visits pampas" (Criollo 52).

The text displays an array of comparisons, both direct and implicit, between the gauchos, their character and habits, their nomadic lifestyle, and the typical landscape that serves as a canvas for their everyday life. The gauchos live in a "Babilonia americana," often surrounded by arid nature; they have mastered the art of horsemanship, much like their Andalusian counterparts ("American Babylon"; Sarmiento, Civilización 25; Sarmiento, Civilization 47). In the gauchos' customs and traditions Sarmiento finds nothing else but "los hábitos pastoriles de la América, reproducidos hasta los trajes, el semblante grave y hospitalidad árabes ("just as we find reproduced in the pastoral habits of America the same grave countenance, hospitality, and dress of the Arabs"; Sarmiento, Civilización 40; Sarmiento, Civilization 60). Even the structure of gaucho society resembles the Oriental, where the ruler, a caudillo, is the omnipotent tyrant and at the same time, an idol, a "Mahoma" whose reputation precedes his actions ("Mohammad"; Sarmiento, Civilización 60). The similarities continue throughout the text.

However, from the very beginning of Sarmiento's account, this Oriental-like image of the gaucho is polarized. One of the avenues of polarization chosen by Sarmiento is precisely the differentiation from the Oriental Other, as well as from the 
rest of the world. While talking about the disdain of the Argentinian gaucho towards the mighty economic potential of the rivers, the author notes that this "obstacle" in the rest of the world had an opposite effect: the river was "lo que hizo la celebridad remotísima del Egipto, lo que engrandeció a la Holanda y es la causa del rápido desdenvolvimiento de Norteamérica" ("what brought celebrity to remote Egypt, what made Holland great, and it is the cause of the rapid development of North America"; Sarmiento, Civilización 24; Sarmiento, Civilization 47). It is curious that, as Emeterio Santovenia and William Katra argue, the Anglo-Saxon America for Sarmiento is a part of this antithesis, and the idealization of this society in his narrative contains implicit criticism of the author's own society (Santovenia 71-72; Katra 80-81). Together with Old Europe and Egypt, a symbol of past civilizations, it serves as a backdrop for his campaign for Latin American selfidentification.

However, just like Sor Juana, Sarmiento does not depart definitively from the European tradition. At the dawn of Argentina's independence he still feels the need to be considered as a part of this tradition in order to attest to his own validity. As such, when describing Facundo Quiroga, Sarmiento notes that, despite not knowing it, the caudillo was "el César, el Tamerlán, el Mahoma” (“a Caesar, a Tamerlane, a Mohammed”; Sarmiento, Civilización 86; Sarmiento, Civilization 100). This desire to define Argentina, and ultimately Latin America, against other established and recognized countries is pivotal for Sarmiento's Orientalism and his treatment of the Other. Julio Ramos in his analysis of the text highlights this Sor Juana-like Orientalism. Ramos suggests that the use of the Oriental Other familiar to the Europeans as his reference 
allows Sarmiento to include Latin America in the literary and historical paradigm of the Old World (42-43).

At the same time, the "graspable" gaucho-Arab connection through Spain had a negative connotation for the representatives of the Generación de 1837, as "these thinkers blamed the political turmoil of mid-1800s Argentina on its having been colonized by a backward country, one they saw as inferior to, and distinct from, Europe (Civantos, Orientalism 21, 26). This assertion puts a new spin on the perception of the self and the Other in Latin America. If Spain is the Other of Europe, due to its marginal position and deep rooted connections to the Orient, Latin America, thus, is Europe's Other as well (hence, the repeated comparisons between the gauchos and the nomadic barbaric tribes). And more importantly, the Colony is no longer perceived as the Other of Spain from the perspective of the criollo insider. The parallel counterbalance for this so-called Oriental axis is the European axis that refers to the antagonistic comparisons between Latin American reality and the European one.

Ramón Menéndez Pidal goes as far as describing Sarmiento’s relationship with Spain as a bitter divorce from his mother-culture despite its continuing influence on him. He criticizes Sarmiento, who “con su acostumbrada violencia, que gustaba más de contemplar los defectos que las cualidades" writes about the metropolis: "Nosotros somos una segunda, tercera o cuarta edición de la España, no a la manera de los libros que corrigen y aumentan en las reimpresiones, sino como malos grabados, cuyas últimas estampas salen cargadas de tinta y apenas inteligibles. Sus vicios son los mismos de que adolecemos nosotros, hijos de tal madre ..." ("with his usual violence, as he preferred to point out defects rather than virtues"; "we are a second, a third or a fourth edition of 
Spain. Not like the books that are corrected and complemented in their new editions, but as bad engravings, whose last imprints are full of ink and are barely visible. Their vice is the same vice we suffer from, we, the sons of such a mother"; Menéndez Pidal, La lengua 136).

This approach was not unique to Sarmiento, as "el siglo XIX ahondó en estas semejanzas: la expresión 'África empieza en los Pirineos' tuvo ecos entusiastas entre los pensadores latinoamericanos ... que explicaba[n] así con facilidad las causas del atraso que habían heredado" ("the nineteenth century focused on these similarities even more intensely. The expression 'Africa begins in the Pyrenees' was echoed enthusiastically by Latin American thinkers who used it as an easy explanation for the backwardness that they inherited"; Taboada 235-36). However, in Facundo, Sarmiento cannot divorce himself completely from his Peninsular heritage. His ambivalent relationship to the metropolis manifests itself in his rhetorical question (note also the linguistic choice): “El problema de la España europea, no podría resolverse examinando minuciosamente la España americana, como por la educación y hábitos de los hijos se rastrean las ideas y la moralidad de los padres? ¿Qué!" ("Could not the problem of European Spain be resolved by closely examining American Spain, much like the upbringing and habits of children may be discerned from the ideas and morals of their parents? So!"; Sarmiento, Civilización 10; Sarmiento, Civilization 33). This historical and cultural interconnectedness defines Sarmiento's approach to the relationship between the self and the Other. The identity crisis in Latin America called for the redefinition of these two entities, and Facundo attests to this process, revealing the underlying struggles of the criollo elite. 
The so-called Oriental and European axes are intertwined in the book, contributing to the complexity of the apparently ambiguous (non-)Oriental and (non)Orientalized Other and self. At the beginning of the first chapter, Sarmiento makes a quintessential remark where he crosses the two axes in the most spectacular and cunning way. And to retain his neutral position as a supreme judge, he conveys his message through a quote from Sir Walter Scott, whose chivalric novels can be considered a perfect example of the romanticized and Orientalized treatment of the Orient. Sarmiento quotes the words of Walter Scott, who sees the vast Argentinian lands "pobladas sino por cristianos salvajes, conocidos bajo el nombre de gauchos . . cuyo principal amueblado, consiste en cráneos de caballos, cuyo alimento es carne cruda y agua y cuyo pasatiempo favorito es reventar caballos en carreras forzadas" ("are populated by Christian savages, known by the name of gauchos ... whose principal furnishings are horses' sculls, whose food is raw meat and water, and whose favorite pastime is racing horses until they burst"; Sarmiento, Civilización 28; Sarmiento, Civilization 51). ${ }^{121}$

This barbaric and primitive Latin American Other, at a first glance, is opposed to the exquisite "cultured" Europe, when Walter Scott continues: "Desgraciadamente . . . prefirieron su independencia nacional a nuestros algodones $y$ muselinas" ("Unfortunately ... they preferred national independence over our cotton and muslins"; Sarmiento, Civilización 28; Sarmiento, Civilization 51). However, ironically, both words that represent the so-called "civilization," algodones and muselinas, are of Arabic origin, hence questioning again the notion of culture and barbarism. This, along with the references from biblical stories and Greco-Roman mythology, gives a new perspective to the Orientalization process in the Americas. Diana Sorensen writes in her analysis of 
Facundo that "when the historical axis is taken into account, the succession of readings becomes part of a semiological chain in which the elements of the system interact with each other" (3). The novel, to a certain extent canonized in Argentine literature, went through several such readings, both within and from outside Argentina, each of them adding to the interpretation of civilization and barbarism, the self and the Other, the Old and the New Worlds.

Sarmiento's predecessors, like Sor Juana, longed to be included in the European cannon, and particularly in Spanish history, for the Colony to be recognized on a par with the metropolis. While not completely departing from that tradition, Sarmiento is looking for a certain separation from Europe, France in particular. Orientalizing the barbaric self, he strives for differentiation and not so much appropriation or reincorporation of the Other into hegemonic culture and history. In doing so, he passes through the process of transculturation and reassessment of European values (Mauro 256). Here lies the key difference between Hispanic Orientalism at the beginning of the Colonial period and after Latin American Independence.

Sarmiento reinforces this thesis by further referring to early European history. The Roman Empire considered all "outsider" cultures "barbaric" - those with different customs, social organization, and languages. Essentially, the so-called barbarians (Germanic tribes, Vikings, etc.) were the Other of Roman civilization, much like Latin America became for Europe. However, Sarmiento separates at the very beginning of his book two similar but unequal terms: salvaje ("savage") and bárbaro ("barbaric") (Sarmiento, Civilización 12). His descriptions of the good-willed but wild natured Facundo, and the atrocities of the Government of Juan Manuel de Rosas (1793-1877), 
and the dictator himself, serve as examples of his reinterpretation of civilization and barbarism, and, as a consequence, of the self and the Other. Facundo Quiroga, while committing atrocities, shows a constant intent of imposing an order on the lands under his control. Sarmiento defines him as barbaric but not as cruel; his life choices are dictated by his lack of education and the natural inclinations of the people of the land. $\mathrm{He}$ is a remorseful murderer, who laments the unnecessary massacres. Facundo is a romanticized wild spirit, who resembles a Medieval knight of the pampas as he appears on a white horse at the beginning of one of the battles. At the same time, Rosas, the representative of modern civilization, whose education would have polished his manners eradicating the barbarism that Facundo possesses, is portrayed as a ruthless assassin. He orders mass killings without any remorse and in excess, putting another spin on Sarmiento's argument about the difference between barbarism and savagery. This reorientation puts a dent in the reigning Eurocentrism of Orientalist discourse. As Hernán Taboada notes, it reveals the process of diversification of the Other in the former Colony:

Como han visto (¿con exageración?) los críticos del orientalismo a partir de Edward Said, el oriental es una proyección a la cual los europeos atribuyen todas las características negativas de las cuales quieren liberar su propia imagen. Es irreductible en su error. El Americano, en cambio, fue el prototipo, que después se iba a ramificar en muchos otros, del hombre natural, que era posible transformar, convertir. Este personaje tenía antecedentes en el pensamiento grecorromano y el árabe, pero 
reencarnó en Europa tras el primer encuentro con pueblos primitivos ... ${ }^{122}$ (231)

The established parallelism between the Oriental and the Amerindian Other, and the revision of the role of the Other in the New and the Old Worlds are crucial for establishing the paradigm of Hispanic Orientalism of the post-Independence period. Civantos goes even further by defining the romanticized and the popularized gaucho as "the true criollo" who is appropriated by the hegemonic ruling class in Argentina (Orientalism 30). This conclusion is significant, as it echoes our argument of Sarmiento's Orientalism as being rooted in early colonial Orientalism, which used appropriation mechanisms to reinvent or reinterpret the Other. On the other hand, Civantos also notes that Sarmiento, in his "drive to formulate an identity" goes through so-called Orientalist "self-essencialization" or "auto-Orientalism," which is her definition of this term, correlates with what we earlier identified as self-Orientalization (Orientalism 51, 215). This confirms our second thesis that the Hispanic Orientalism found in Facundo represents a step forward from appropriation and into differentiation, which is carried out through Orientalizing the self, something that was earlier observed, for instance, in the writings of Sor Juana.

It is Sarmiento's oscillation between the Other and the self, and his ultimate reinterpretation of both that defines his Orientalism. This multiplicity of voices is what reflects the "heteroglot reality" and the shift between the notions of civilization and barbarism captured in the pages of Facundo (Civantos, Orientalism 34, 222). In his Orientalist approach to the new Argentinian reality Sarmiento makes the first natural step "del orientalismo al americanismo," serving as a precursor of modern Hispanic 
Orientalism that aims toward differentiation ${ }^{123}$ ("from the Orientalism to Americanism"; Taboada 215). Even Sarmiento himself uses this term in his closing remarks. His opposition to Europe, partly as a reaction to the government's purposes of "whitening" the nation, results in his desire to affirm his country's own identity despite and in conjunction with Europe.

One of the bases for differentiation in Facundo, is that the Other, in the process of self-Orientalization, in given a chance to speak for himself. Since the early times of exploration, there were intents to give voice to the silenced Other, for instance, in the ethnographic works of some missionaries. Indigenous art towards the seventeenth century also manifests itself as liberating and raising the indigenous voice, ${ }^{124}$ contrary to the mainstream castas paintings created mostly by criollos or, through very rarely, by Spanish painters like Francisco Clapera (Mauro 257). Sarmiento not only seeks to give a voice to the Argentinian gaucho, the Other of civilization, but also to the criollo, as himself, who was for centuries, the colonial Other for the metropolis. In doing so, he intends to break up with the traditional segregation established between the hegemonic colonizer and the subaltern colonized, as well as to reevaluate the roles of the self and the Other within his own society.

In sum, Sarmiento, caught in political transition, exists between the past and the future of Hispanic Orientalism. As his predecessors from the early Colonial period, he uses preconstructed stereotypical images of the Oriental Other as a reference, this time for the barbaric self, the gaucho, in his dichotomy between civilization and barbarism. Like the castas painting, he attempts to classify the Other (hence, his types of gauchos in Chapter II: el rastreador, el baqueano, el gaucho malo, el cantor) for the purpose of 
its being catalogued and controlled by civilized society. However, as does the earlier Sor Juana, he attempts to give voice to the Other. By portraying Facundo as a romantic character he creates admiration for him in his readers. While complaining about the gauchos" "lack" of civilization and education, Sarmiento admires their natural intelligence and skills, and their rough but sensitive nature. He inadvertently praises the Other, the "barbarian," the counterpart of the dreaded Orient at the time of the Reconquest, thus undergoing the process of self-Orientalization for the purpose of differentiation from the European self and European-bound political movements in Argentina. Francisco Goyogama contemplates the possibility that Sarmiento shared the views of el deismo, a more liberal Christian theology, that cultivated "la razón," that consequently, "se convierte en la presuposición de la tolerancia que encuentra expresión en la rebelión contra la ortodoxia y el dogmatismo ("becomes a presupposition of the tolerance that finds its way in the rebellion against orthodoxy and dogmatism"; 244). In this light, it is of no surprise that Sarmiento prefers the "barbarity" of Facundo to Rosas's regime.

Sarmiento's criollismo, paraphrasing the words of Covadonga Lamar Prieto, is indebted to the new neo-Latin tradition based on cultural self-validation and recognition of the argentinidad of the criollos, but also keeping in mind their Peninsular heritage (80). This process of rethinking the self will eventually lead to hispanismo as the reconciliation and the revalorization of Spanish heritage in the Americas, as Civantos defines it (Criollo 27), as well as a more global reconciliation with the general Other, be it the Orient per se, as in the works of Borges, or the newly constructed Others, as in the works of Enrique Gómez Carrillo. It also marks a new stage of Hispanic Orientalism 
that gravitates towards self-Orientalization as a means of recognizing its own uniqueness and difference from the metropolis, as well as the rest of the world. In this sense, modern Hispanic Orientalism came to life as a consequence of the successful struggle for independence in Latin America. It was defined by the shift in political powers, as well as the shift in cultural hegemony.

\section{§ 5. Conclusion}

The late Colonial and the early Independence periods in Latin American constitute a transition from a subsidiary role in the world's political arena to a more prominent position as a sovereign entity. They also marked a transition in the paradigm of Hispanic Orientalism, which was significantly affected by the change of powers. During this time, Hispanic Orientalism displayed both the characteristics of the previous Colonial period that reinvented and reinterpreted the Other, but toward Independence, it also gradually gravitated towards a newer model based on differentiation.

The basis for this can be found in what Claudia Parodi defines as a cultural clash between two civilizations that led to a creation of a new one "que incorporó elementos culturales procedentes de los dos grupos en contacto, del medio americano y de su 'reinvención' en el Nuevo Mundo" ("that incorporated cultural elements from both groups in contact, the American milieu and its 'reinvention' in the New World"; 29).

From it, "la emergencia de una conciencia o identidad criolla en los virreinatos latinoamericanos, sobre todo en Nueva España" emerges during the seventeenth century ("the formation of Criollo identity or self - awareness in the Latin American 
viceroyalties, especially in New Spain"; More 72). It is heavily based on the hegemonic elite's search for its own identity and history, as distinct from Europe. In the writings by Sor Juana this oscillation between the desire to be equal to Europe and distinct at the same time became extremely prominent. In order to achieve balance between these two opposites, she resorts to self-Orientalization that springs out from the early colonial tradition of reinterpretation. However, her constant comparisons of Mexico to the metropolis are colored by the desire to differentiate herself from the hegemonic power. Although she does not fully embrace differentiating Orientalism, her approach foreshadows the post-Independence Orientalism of the late nineteenth and twentieth centuries.

While Sor Juana's approach to the treatment of the self and the Other was rather innovative compared to the early colonial writings, the seventeenth-century castas paintings represent, in a sense, a step back to traditional Peninsular Orientalism. Manifestations and reflections of the dominant colonial system, castas paintings skillfully used reinterpretation of the Amerindian Other in order to create the parameters of a rigid society based on race and blood purity. Unlike the literary works of the period, castas paintings were made to order and by the order, permitting the hegemonic society to legitimize its position. Exported to the metropolis, these depictions of Colonial life served as a confirmation of the image of the reinvented Amerindian Other, existing in the popular mentality in the Old World.

The clash of the Peninsular and Latin American views of the self and the Other sharpened towards the eighteenth century. As Jorge Rueda de la Serna points out, the process of mythmaking was intense on both sides of the spectrum: the image of the 
fertile and rich Colony and the natural intellect of its inhabitants was often outweighed by the image created by the dominant society, that of the degeneration of the European, especially the Spanish, race in the New World under the pernicious influence of its malignant climate that converted them into lazy and disloyal subjects, incapable of the great deeds of their ancestors (Rueda de la Serna 218). Anouar Majid finds an echo of this self-purifying tradition in Spain's need to "exorcise the ghost of its own mestizaje" (161); a dark spot on the crown of the metropolis. The eighteenth-century crisis in Europe sharpened this opposition, resulting in the consequent independence of most of the Colonies and the gradual separation of the overseas Hispanic Orientalism from the Peninsular.

This process of drifting away from the Peninsular tradition can be clearly seen in Sarmiento's Facundo, where his oscillation between the sociocultural phenomena of civilización and barbarie echo the above delineated traditional myths of the self and the Other. Sarmiento, much more prominently than Sor Juana before him, leans toward the revision of the traditional role of the former Colony through the process of selfOrientalization and differentiation from the traditional superpowers that become the Other of Latin America. This process will intensify in the upcoming century when the Latin American states become more established after having gone through political turmoil. Hispanic Orientalism will expand the notion of the Other: it will no longer be exclusively associated with the Orient, the traditional Other of the Peninsular Medieval tradition, but will embrace the other nations, including the former colonizer and emerging powers such as United States. 
In their effort to revise Latin America's role in world history, both Sor Juana and more so Sarmiento (unlike the mainstream castas paintings) tried to rescue the marginalized, read Orientalized, criollo identity, reinterpreted by hegemonic society. This was the result of the fact that "the criollo population of New Spain was beginning to grow, as was their sense of entitlement as they emerged from the secondary status they had had compared to the ruling European-born elite. The marginalization of these people, who were full blooded Spanish, demonstrates the importance of place in defining one's identity in colonial . . culture" (M. González 143). This subtle balance between the Orientalism that serves the purpose of segregation of the Other within its own society and the Orientalism that establishes the validity and the uniqueness of that society through self-Orientalization and differentiation from the European Other determined the definition of this period as transitional for the development of the Hispanic Orientalist paradigm.

As a result, the transitional period of the Hispanic Orientalist cultural paradigm marked a sharp break with the Peninsular tradition in the perception of self and Other, since Independence, in a way, inverted these roles. However, the Orientalization mechanisms did not change so dramatically. While appropriation through reinterpretation still takes place in the narrative of this early transitional period, it gradually gives way to the process of differentiation. Its integral part is selfOrientalization, a way to review the role and position in the world of the former Latin American Other. 


\section{NOTES}

${ }^{92}$ Hernán Taboada notes that after the year 1580:

se abrió una etapa de relativa paz e incluso desaparecieron algunos aspectos de la intolerancia española: la literatura del Siglo de Oro adoptó con entusiasmo el tema del Turco. En lo que respecta a Indias, esto significo el alivio en el hostigamiento naval . . . las relaciones de España con Marruecos adquirieron mayor cordialidad y los ataque piratas las costas españolas disminuyeron en el siglo XVII. Por su parte, los otomanos se apartaron de las rutas atlánticas; hacia aquella época consolidaron su poder en el Cáucaso, Yemen y el Mar Rojo. (171-72)

${ }^{93}$ The full quote and its translation is as following:

Durante siglos, los varones de la Cristiandad latina se habían distinguido de los muslimes o los judíos por su ausencia de barba. Al arribar al Nuevo Mundo anotaron, acertadamente o no, que su modalidad lampiña era compartida por los amerindios, cuya escasa pilosidad empezó a convertirse en un rasgo básico de las descripciones. Que los europeos comenzaran a portar barba a partir del siglo XVI es un hecho, y en alguna medida, aunque con seguridad la causalidad no es tan directa, el cambio nos señala que el Otro por excelencia, del cual había que distinguirse, no era ya el judío/muslim, sino el amerindio. (232)

During centuries, the men in Latin Christianity distinguished themselves from the Muslims and the Jews through the absence of a beard. When they arrived to the New World, they noticed, rightly or wrongly, that their beardless appearance was shared by the Amerindians, whose sparse hairiness gradually became their basic feature. It is a fact that the Europeans started growing beards beginning with the XVI century, and in a way, even though its causality is not so obvious, this change shows us that the Other, from which they wanted to distinguish themselves was not any more a Jew or a Muslim, but the Amerindian. (The translation is mine $-S . T$.)

${ }^{94}$ The translation is mine (S. T.)

${ }^{95}$ Sor Juana creates a color juxtaposition between the two world. "Nuestro Oriente" is called "lunimoso" while "su Occiedente" has "su luz en trémulos desmayos" (De la Cruz 200-01). Throughout the poem, two semantic groups define the two worlds: sol, luminoso, oro, colores, luz on one hand, representing the New World, and negro, sombra, reflejos, noche symbolize the past. Sor Juana even directly calls them "antípoda" (De la Cruz 200). 
${ }^{96}$ The more dramatic is "visüal alado atrevimiento" and the "señales externas," their "ambiciosa llama ardiente" only reinforces the image of "su figura trasunta" that cannot be compared to "mental pirámide elevada" from the summit of which these achievements look "tan atrasados" ("visual alated audacity"; "extreme signs"; "ambitious burning flame"; "its transitory figure"; "high-rising mental pyramid"; " so far away"; De la Cruz, Obra 190-91).

${ }^{97}$ The worlds seem to from a geometrical figure: a pyramid and an inverted pyramid that have only one point in common: the both pyramids summit. This is significant for Sor Juana's interpretation of the relationships of the two worlds. The inverted pyramid has an additional symbolic religious meaning as a representation of Holy Trinity (for instance, in the icons, where the space between the eyebrows and the nose of a holy figure was painted, following the Byzantine tradition, as forming an inverted pyramid that symbolized the Holy Spirit, the God Father and the Son.

98 The Oriental play on words "fiel infiel" for Sor Juana becomes the quintessential Other ("faithless faithful"; Obra 186).

${ }^{99}$ There were, for example, different monasteries for only while or only Indian nuns (León 5). In the Inde pro Indis (Edición Lorenzana), we read: "No se ordene sin gran discernimiento a los MESTIZOS, ya vengan de INDIOS o de MOROS, ni a los descendientes en primer grado de los que por parte de padre o de madre vengan de NEGROS" (qtd. in León 6). It is indicative of the Orientalist thinking of the period that the Moors, the conquered enemy that did not pose any significant threat to the colony was still under the scrutiny of the hegemonic society.

${ }^{100}$ In the light of the constant interracial mixing, it is important to note that the culture and the customs could not avoid certain level of interpenetration. For instance, María Concepción García Sáiz notes that the cultural and religious syncretism was natural in the New World. As an example, she points out that the presence of Inca in two versions of Adoration of Magi did not produce a dissonance, as "it would be like a European artist portraying an indigenous figure to conjure up other parts of the world" (36).

${ }^{101}$ See the first part of the above mentioned verse:

En el idioma Olandesa

Al culo le llaman cri,

Porque el llamarlo así

En su idioma se profesa

Viendo término más chulo

Con más cortés disimulo 
Al culo le llaman hollo;

Hollo y cri decen Crihollo

Y Crihollo es ojo de culo. (León 18)

102 León mentions the following castes: Ahi o Hay Te Estás, Albarasado (Albarrasado), Albino, Barzino, Cabra, Cambujo, Campamulato (Calpamulato), Castizo, Coyote, Coyote Mestizo, Cuarterón, Cuarterón de Chino, Cuarterón de Mestizo or Español, Cuarterón de Mulata, Chamiso, Chino, Cholo, Español or Españolo, Galfarro, Gente Blanca, Gíbaro, Grifo or Tente en el Aire, Harnizo, Jarocho, Limpis, Lob, Lunarejo, Mequimixtos, Mestindio, Mestiz, Morisco, Mulato, Mulato Obscuro, No Te Entiendo, Octavón (Ochavón), Postizo, Puchuela, Puchuela de Negro, Quinterón, Quinterón de Mestizo, Quinterón de Mulato, Requinterón de Mestizo or Español, Requinterón de Mulata, Rayados, Sambayo (Sambaigo, Sambahigo), Saltarás, Saltatrás Cuarterón, Saltatrás Quinterón, Tente en el Aire, Tercerón or Cuanterón Cuatralvo, Tresalvo, Torna antrás, Zambo, Zambo Prieto, Zambis (21-27).

103 Bonnie Gasior mentiones the following groups: Albarazado, Albino ("albine"), Barzino, Cambujo, Campa mulato, Cuarterón ("Quadroon," fourth generation), Cuarterón de mulata, Cuarterón de Chino ("Quadroon of Chinese"), Chino ("Chinese"), Genizaro ("Janissari"), Galfarro ("Lazyboy"), Gente blanca ("White people"), Gíbaro, Grifo, Jarocho, Lobo ("Wolf"), Morisco ("Mosrisco, of Moorish descend"), Mulato, Mulato obscuro ("Dark Mulatto"), No te entiendo ("I-don'tunderstand-you"), Pachuela de negro, Quinterón (fifth generation), Requinterón de mulata, Saltartrás cuarterón (“Jump back Quadroon”), Saltatrás quinterón, Tente en el aire ("Be in the air"), Tercerón (third generation), Zambo, Zambo prieto ("Black Zambo") (1:245).

104 The first major exhibit of castas paintings, "Inventing Race through Art," took place in Los Angeles in 2004 at Los Angeles County Museum of Art (Gasior $1: 246)$.

105 The classification depicted in the castas paintings was undoubtedly a mechanism of social control. In it, the existing classifications of the period found their reflection: "gente de razón" (people with reason) were opposed to the Indians; "gente decente" (respectable people) were against the plebs, and tributaries were opposed to non-tributaries (Katzew 43).

${ }^{106}$ According to Ilona Katzew, the subordinate position of people of African descent could be explained by the following:

Being black not only presupposed a possible Muslim background but also pointed to slavery and atavistic ancestry. In fact, blacks were long 
thought to be a damned people directly descended from Ham, Noah's youngest son. Genesis 10:9 relates that Ham committed a hubristic act when he exposed his father's nakedness to his brothers Shem and Japhet while Noah was asleep drunk. Upon waking up and realizing what Ham had done, Noah cursed him, condemning Ham's son Canaan to perpetual servitude. (46)

A similar explanation was offered with another biblical reference: blackness was considered a curse that God bestowed on Cain for the murder of his brother Abel (Carrera 11).

${ }^{107}$ Ilona Katzew quotes here the copy of the manuscript (c. 1735) that belonged to the Minister of the Marine, Don Antonio Enríquez: "No se hace mas distincion que blancos, ó de mano prieta: los primeros son los Europeos y sus descendientes, que se llaman criollos ... de mano prieta se llaman o entienden mestizos, coyotes, mulatos, lobos, zambaigos, moriscos, salta atrás, tente en el aire, gíbaros, chinos, e yndios los quales son la mayor población del reíno y los que componen los pueblos entre los que tienen estimacion los caciques y tlascaltecos, que son los que tanto ayudaron a Cortés en su Conquista" (sic) (Anonymous. Descripción del Estado político de la Nueva España. N. d. MS 9-4799, fol. 367г. Real Academia de Historia, Madrid, Spain).

108 According to Nicolás León's research, the racial components of the Albarazado and the Barcino group can be represented by the following chart (20):

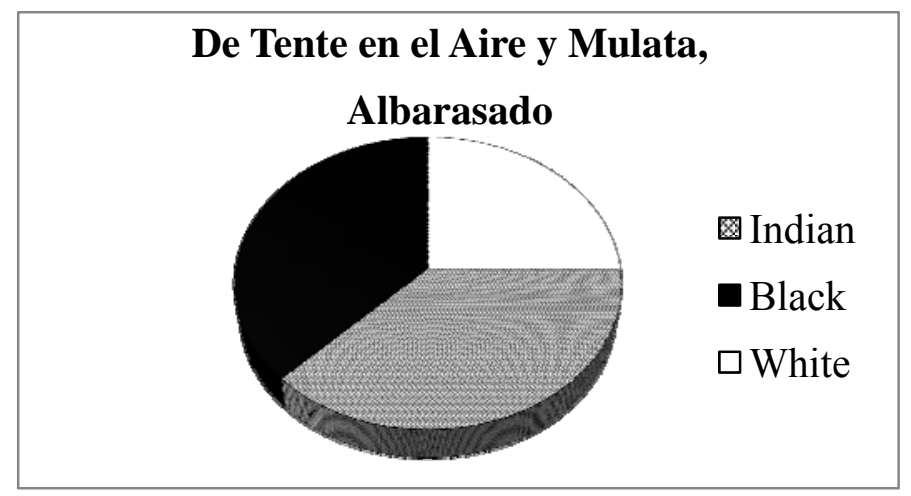




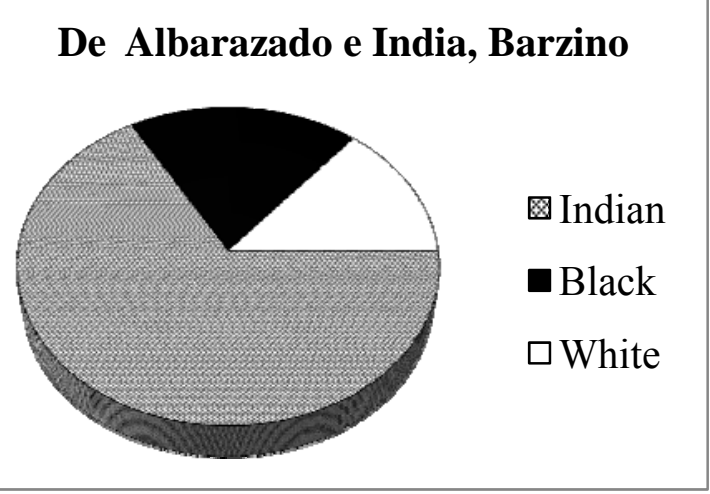

${ }^{109}$ For instance, Nicolás León in his research mentions nine collections of castas painting series, most of which contain images of both the Albarazado and Barcino parents and offsprings (28-65). See the following table:

Representation of the Albarazado and the Bercino group in the castas paintings of the eighteenth century

\begin{tabular}{|c|c|c|c|c|c|}
\hline Collection & $\begin{array}{c}\# \\
\text { (out of) }\end{array}$ & $\begin{array}{c}\text { Barcino } \\
\mathbf{O}^{*}\end{array}$ & $\begin{array}{c}\text { Barcino } \\
\mathbf{P}^{* *}\end{array}$ & $\begin{array}{l}\text { Albarazado } \\
\quad 0\end{array}$ & $\begin{array}{c}\text { Albarazado } \\
\text { P }\end{array}$ \\
\hline $\begin{array}{l}\text { Museo Etnográfico del } \\
\text { Trocadero (París, Francia). } \\
\text { Ignacio de Castro, fines del s.18. }\end{array}$ & $\begin{array}{l}9 / 16 \\
I^{* * *}\end{array}$ & $\# 13$ & $\# 14$ & & \\
\hline $\begin{array}{l}\text { Museo de Historia Natural. } \\
\text { Madrid. Anónimo, s. } 18 .\end{array}$ & $\begin{array}{l}17 \\
\mathrm{I} ?\end{array}$ & & & & \\
\hline $\begin{array}{l}\text { José Joachin Magón, fines del } \\
\text { s.18. (más moderna). }\end{array}$ & $\begin{array}{l}16 \\
\mathrm{I} ?\end{array}$ & & & $\# 15$ & $\# 16$ \\
\hline $\begin{array}{l}\text { José Joachin Magón, fines del } \\
\text { s.18. (más Antigua). }\end{array}$ & 20 & & & + & \\
\hline $\begin{array}{l}\text { Casa de Beamore-Hants } \\
\text { (Inglaterra). Hijo ilegítimo de } \\
\text { Murillo? S. } 18 .\end{array}$ & 14 & & & & \\
\hline $\begin{array}{l}\text { Colección Larrauri-Montaño. } \\
\text { (Mich.). }\end{array}$ & 16 & $\begin{array}{c}\# 12 \\
\text { Barnocino }\end{array}$ & $\begin{array}{c}\# 13 \\
\text { Barnocino }\end{array}$ & $\# 11$ & $\# 12$ \\
\hline $\begin{array}{l}\text { Museo Nacional de México. S. } \\
18 .\end{array}$ & $\begin{array}{l}16 \\
\text { cuadre- } \\
\text { tes }\end{array}$ & & & $\# 10$ & \#11 \\
\hline $\begin{array}{l}\text { Collección Riva-Palacio. } \\
\text { Museo Nacional de México. } \\
\text { Princ. del s. 19? }\end{array}$ & 16 & $\# 12$ & $\# 13$ & \#11 & $\# 12$ \\
\hline
\end{tabular}




\begin{tabular}{|l|c|c|c|c|c|}
\hline $\begin{array}{l}\text { Collección del Museo Nacional } \\
\text { de México. J. Ignacio Castro, } \\
\text { fines del s. 18. }\end{array}$ & $\begin{array}{l}7 \\
\text { I }\end{array}$ & $\begin{array}{c}\# 13 \\
\text { Varsino }\end{array}$ & & $\begin{array}{c}\# 12 \\
\text { Alvarrasado }\end{array}$ & $\begin{array}{c}\# 13 \\
\text { Alvarrasado }\end{array}$ \\
$\begin{array}{l}\text { Anónimo, fiena (Austria). } \\
\text { del s. 19? }\end{array}$ & $\begin{array}{c}10 / 19 \\
\text { I }\end{array}$ & $\# 18$ & $\# 19$ & $\begin{array}{c}\# 10 \\
\text { Albarrasada }\end{array}$ & \\
\hline
\end{tabular}

\section{Abbreviations:}

O* - offspring

$\mathbf{P}^{* *}$ - parent

I*** - incomplete collection

$+* * * *$ - present but no specified, which one.

${ }^{110}$ Among the collections, described by Nicolás León, one can find a certain pattern of the appearance of the three castes, being the most popular, the image of the Moriscos, and the least - the Genizaros (28-65).

\section{Representation of the Morisco, Chino and Genízaro group in the castas paintings of the eighteenth century}

\begin{tabular}{|c|c|c|c|c|c|c|}
\hline Collection & $\begin{array}{c}\# \\
\text { (out of) }\end{array}$ & $\begin{array}{c}\text { Morisco } \\
\text { O* }\end{array}$ & $\begin{array}{c}\text { Morisco } \\
\text { P** }\end{array}$ & $\begin{array}{c}\text { Chino } \\
\text { O }\end{array}$ & $\begin{array}{l}\text { Chino } \\
\mathbf{P}\end{array}$ & $\begin{array}{l}\text { Genízaro } \\
\mathbf{O}\end{array}$ \\
\hline $\begin{array}{l}\text { Museo Etnográfico del Trocadero } \\
\text { (París, Francia). Ignacio de } \\
\text { Castro, fines del s.18. }\end{array}$ & $\begin{array}{l}9 / 16 \\
I^{* * *}\end{array}$ & $\# 5$ & \#6 & $\# 9$ & $\# 10$ & \\
\hline $\begin{array}{l}\text { Museo de Historia Natural. } \\
\text { Madrid. Anónimo, s. } 18 .\end{array}$ & $\begin{array}{l}17 \\
\mathrm{I} ?\end{array}$ & & & \#17 & & \\
\hline $\begin{array}{l}\text { José Joachin Magón, fines del } \\
\text { s.18. (más moderna). }\end{array}$ & $\begin{array}{l}16 \\
\mathrm{I} ?\end{array}$ & $\# 5$ & \#6 \#15 & & & \\
\hline $\begin{array}{l}\text { José Joachin Magón, fines del } \\
\text { s.18. (más antigua). }\end{array}$ & 20 & $+* * * *$ & + & $\begin{array}{l}\# 17 \\
\# 18\end{array}$ & \#18 & \\
\hline $\begin{array}{l}\text { Casa de Beamore-Hants } \\
\text { (Inglaterra). Hijo ilegítimo de } \\
\text { Murillo? S. } 18 \text {. }\end{array}$ & 14 & $\# 13$ & \#12 & & & \\
\hline $\begin{array}{l}\text { Colección Larrauri-Montaño. } \\
\text { (Mich.). }\end{array}$ & 16 & $\# 5$ & \#6 & & $\# 10$ & \\
\hline $\begin{array}{l}\text { Museo Nacional de México. S. } \\
18 .\end{array}$ & $\begin{array}{c}16 \\
\text { cuadret } \\
\text { es }\end{array}$ & $\# 5$ & \#6 & \#6 & $\# 7$ \#9 & \\
\hline $\begin{array}{l}\text { Collección Riva-Palacio. Museo } \\
\text { Nacional de México. Princ. del s. } \\
19 \text { ? }\end{array}$ & 16 & \#5 & \#6 & & & \\
\hline
\end{tabular}




\begin{tabular}{|l|c|c|c|c|c|c|}
\hline $\begin{array}{l}\text { Collección del Museo Nacional de } \\
\begin{array}{l}\text { México. J. Ignacio Castro, fines } \\
\text { del s. 18. }\end{array}\end{array}$ & $\begin{array}{l}7 \\
\text { I }\end{array}$ & & & $\# 9$ & & \\
\hline $\begin{array}{l}\text { Museo de Viena (Austria). } \\
\begin{array}{l}\text { Anónimo, fines del s.18/ Princ. del } \\
\text { s. 19?. }\end{array}\end{array} \begin{array}{c}10 / 19 \\
\text { I }\end{array}$ & $\# 5$ & $\# 6$ & & & $\# 19$ \\
\hline
\end{tabular}

Abbreviations:

O* - offspring

$\mathbf{P}^{* *}$ - parent

I*** - incomplete collection

$+* * * *$ - present but no specified, which one.

Another indicative comparison of the popularity of the three castes can be seen in the following table, based on the seminal catalogue by María Concepción García Sáiz (Las Castas Mexicanas: Un Genero Pictorico Americano. Milan: Olivetti, 1989. Print.). The reason for differentiating the two tables is that, at the moment of research, it was impossible to establish, which of the painting collections overlap, since there was 65year gap between the two publications. However, both provide a similar picture, which proves the hypothesis about the existence of the relation between the popularity of the group and the familiarity of the non-American Other among the hegemonic society.

The castas paintings by Francisco Clapera were not included in this catalogue. Since the number of incomplete collections was considerable, only the collections containing seven and more paintings were selected for this table. Both the complete and incomplete collections are clearly marked; it is followed by the number of painting in the catalogue, as well as the total number of paintings (where available). The reason for selecting seven representations as the minimum is due to the fact that the castas paintings usually consist of twelve or fourteen images, so seven images constitute about at least half of an average castas paintings series. The school of painting is also kept in the description, as there are significant differences in representation of castes between them.

\section{Representation of the Morisco, Chino and Genízaro group in the castas paintings of the eighteenth century}

\begin{tabular}{|c|c|c|c|c|c|c|c|c|}
\hline School/Author/ Collection & Quality & $\begin{array}{c}\# \\
\text { aval.// } \\
\text { total }\end{array}$ & $\begin{array}{c}\mathbf{M} \\
/ \\
\mathbf{C}\end{array}$ & $\begin{array}{l}\mathbf{M} \\
/ \\
\mathbf{P}\end{array}$ & $\begin{array}{l}\mathbf{C} \\
\text { / } \\
\mathbf{C}\end{array}$ & $\begin{array}{l}\mathbf{C} \\
\text { / } \\
\mathbf{P}\end{array}$ & $\begin{array}{l}\mathbf{G} \\
/ \\
\mathbf{C}\end{array}$ & $\begin{array}{l}\mathbf{G} \\
/ \\
\mathbf{P}\end{array}$ \\
\hline $\begin{array}{l}\text { Mexican school. Private collection, Breamore } \\
\text { House, London, England. }\end{array}$ & I? & 14 & + & + & - & - & - & - \\
\hline Mexican school. Private collection. & $\mathrm{C}^{*}$ & & + & + & + & - & - & - \\
\hline $\begin{array}{l}\text { Luis de Mena. 1750. Museo de Américas, Madrid, } \\
\text { Spain. }\end{array}$ & I ?* & 8 & + & + & - & - & - & - \\
\hline $\begin{array}{l}\text { Mexican school (M. Cabrera, 1763). Private } \\
\text { collection / Museo de Américas, Madrid, Spain. }\end{array}$ & $\mathrm{I}$ & $13 / 16$ & + & - & + & + & - & - \\
\hline
\end{tabular}




\begin{tabular}{|c|c|c|c|c|c|c|c|c|}
\hline $\begin{array}{l}\text { Mexican school (J. Joachin Magon, 1770?). Museo } \\
\text { Nacional de Etnografía, Madrid, Spain. }\end{array}$ & $\mathrm{C}$ & & + & + & - & - & - & - \\
\hline $\begin{array}{l}\text { Andean school (1770-1780?). Museo Nacional de } \\
\text { Etnografía, Madrid, Spain. }\end{array}$ & $\mathrm{C}^{* *}$ & & - & - & + & + & - & - \\
\hline $\begin{array}{l}\text { Mexican school (Andrés de Islas, 1774). Museo de } \\
\text { Américas, Madrid, Spain. }\end{array}$ & $\mathrm{C}$ & & + & + & + & + & - & - \\
\hline $\begin{array}{l}1774 \text { (Illustrations in Idea Compendiosa del Reyno } \\
\text { de Nueva España by Pedro Alonso O’Crowley). } \\
\text { Biblioteca Nacional, Madrid, Spain. }\end{array}$ & $\mathrm{C}$ & & + & + & - & + & - & - \\
\hline $\begin{array}{l}\text { Mexican school (S. Salcedo, 1779?). Private } \\
\text { Collection, Avila, Spain. }\end{array}$ & I & $12 / 14$ & + & + & - & - & - & - \\
\hline $\begin{array}{l}\text { Mexican school (I. M. Barreda y Ordóñez, 1777). } \\
\text { Real Academia Española de la Lengua, Madrid, } \\
\text { Spain. }\end{array}$ & $\mathrm{C}^{*}$ & & + & + & + & + & + & + \\
\hline $\begin{array}{l}\text { Mexican school (last quarter of } 18^{\text {th }} \text { century). } \\
\text { Museo de Américas, Madrid, Spain. }\end{array}$ & $\mathrm{C}$ & & + & + & + & + & - & - \\
\hline $\begin{array}{l}\text { Mexican school (I. de Castro?). Museo Nacional, } \\
\text { Mexico. }\end{array}$ & $\mathrm{I}$ & 7 & - & - & + & - & - & - \\
\hline $\begin{array}{l}\text { Mexican school (I. de Castro, 1775-1785?). Musée } \\
\text { de L’Homme, Paris, France. }\end{array}$ & I & $10 / 16$ & + & - & - & - & - & - \\
\hline $\begin{array}{l}\text { Mexican school. Instituto de Cultura } \\
\text { Puertorriqueña, San Juan de Puerto Rico. }\end{array}$ & I & $15 / 16$ & + & + & + & + & - & - \\
\hline Mexican school. Private collection, Mexico. & $\mathrm{C}$ & & + & + & - & - & + & + \\
\hline $\begin{array}{l}\text { Mexican school (Disciple of M. J. Zendejas, } \\
\text { 1780s). Private collection, Mexico. }\end{array}$ & $\mathrm{C}^{*}$ & & + & + & + & + & - & - \\
\hline $\begin{array}{l}\text { Mexican school. (18th century). Museo del } \\
\text { Virreinato, Tepotzotlán, Mexico. }\end{array}$ & $\mathrm{C}^{*}, * * *$ & & + & + & + & + & - & - \\
\hline $\begin{array}{l}\text { Mexican school (M. Cabrera's circle). Private } \\
\text { collection, Mexico. }\end{array}$ & I & $8 / 16$ & - & + & - & - & - & - \\
\hline $\begin{array}{l}\text { Mexican school. Private collection / Banco } \\
\text { Nacional de México, Mexico. }\end{array}$ & $\mathrm{C}^{* * * *}$ & & + & $\begin{array}{l}\mathrm{n} \\
/ \\
\mathrm{a}\end{array}$ & + & $\begin{array}{l}\mathrm{n} \\
/ \\
\mathrm{a}\end{array}$ & - & $\mathrm{n} / \mathrm{a}$ \\
\hline $\begin{array}{l}\text { Mexican school (J. de Páez, mid } 18^{\text {th }} \text { century?). } \\
\text { Private collection. }\end{array}$ & I ? & 15 & + & + & + & - & - & - \\
\hline $\begin{array}{l}\text { Mexican school (J. Alfaro, 1787). Whereabouts } \\
\text { unknown. }\end{array}$ & I? & 12 & + & + & - & - & - & - \\
\hline $\begin{array}{l}\text { Mexican school (end of the } 18^{\text {th }} \text { - beginning of the } \\
19^{\text {th }} \text { century). Museum für Völkerkunde, Vienna, } \\
\text { Austria. }\end{array}$ & I & 10 & + & + & - & - & - & - \\
\hline $\begin{array}{l}\text { Mexican school (end of the } 18^{\text {th }} \text { century). Museo } \\
\text { Nacional, Mexico. }\end{array}$ & I & $12 / 16$ & + & + & - & - & - & - \\
\hline $\begin{array}{l}\text { Mexican school. Former Angel Cristóbal } \\
\text { collection. }\end{array}$ & $\begin{array}{l}\text { C*, } \\
* * *, \\
* * * *\end{array}$ & & + & $\begin{array}{l}\mathrm{n} \\
/ \\
\mathrm{a}\end{array}$ & - & $\begin{array}{l}\mathrm{n} \\
/ \\
\mathrm{a}\end{array}$ & - & $\mathrm{n} / \mathrm{a}$ \\
\hline $\begin{array}{l}\text { Mexican school (J. de Páez, } 18^{\text {th }} \text { century). Private } \\
\text { collection, Mexico. }\end{array}$ & I & $8 / 16$ & - & - & + & - & - & - \\
\hline $\begin{array}{l}\text { Mexican school. Private collection, Michoacán, } \\
\text { Mexico. }\end{array}$ & $\mathrm{C}^{*}$ & & + & + & - & + & - & - \\
\hline
\end{tabular}




\begin{abstract}
Abbreviations:
$\mathrm{M} / \mathrm{C}$ - Morisco child

$\mathrm{M} / \mathrm{P}$ - Morisco parent

$\mathrm{C} / \mathrm{C}-$ Chino child

$\mathrm{C} / \mathrm{P}-$ Chino parent

$\mathrm{G} / \mathrm{C}$ - Genizaro child

$\mathrm{G} / \mathrm{P}-$ Genízaro parent

$\mathrm{C}$ - complete

I - incomplete.

* One painting with sections representing different castes

** The Criollo group is mentioned in the painting

*** The Moro group is mentioned in the painting

**** The painter depicted only representatives of the respective groups. The author did not use the "standard" composition for the castas paintings (parents and their offspring).
\end{abstract}

There are several conclusions that can be drawn from the table above. First of all, the Morisco groups (both children and parents) appear on the overwhelming majority of the paintings (the exceptions being only the incomplete painting). At the same time, the Genizaro group was depicted only twice, which confirms the volatile nature of the name of this group, as sometimes the same parents whose offspring is Genizaro, give birth to the offspring denominated belonging to a different group, i.e., both Genizaro and Lobo can have parents who are Torna-atrás and India (García Sáiz 26-29). Unlike the names of the other Orientalized groups, the Genizaros seemed not to take root in the New World. Unlike them, the Chinos are well represented in the castas paintings. The dominant are the paintings of the offsprings rather than the Chino parents. As well, this groups has several subgroups, reflected in some of the paintings (Chino Cambujo, Chino Alvarazado, etc.), which indicated the transparency of the margins of this groups.

111 The tentative racial structure of the Morisco is the following (León 20):

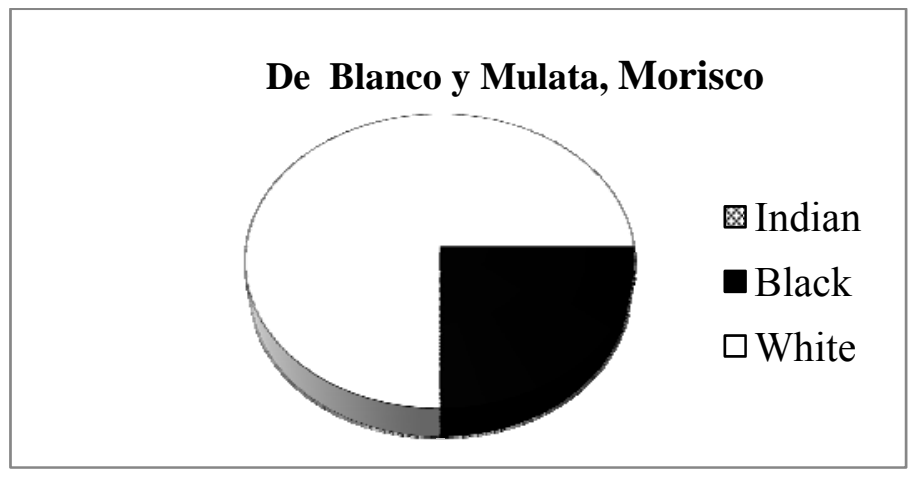

112 The Morisco children are constantly depicted in the castas paintings series. Some of them include the paintings by Francisco Clapera (1775) and another anonymous painting (1765); Miguel Cabrera's painting (1763), Andrés de Islas's (1774), 
José Joaquín Magón (c. 1770), Las castas painting (18 ${ }^{\text {th }}$ century) by anonymous in Museo del Virreinato, Tepotzotlán, among others. In most of the paintings, coincides not only the origin of the Latin American Moriscos (child of Spaniard and Mulatta), but also the order in which his representation appears in the series (often, it is the $5^{\text {th }}$ ). It is also significant, that in the taxonomic chart of castes in the Colony by María Concepción García Sáiz, unlike the Chinos and the Genizaros, who present a more complicated racial mixture and whose parents can vary, the Moriscos can be born from to Spanish and Mulatto parents only (24-25).

${ }^{113}$ The figure of Francisco Clapera (1746-1810) is of special interest for the process of Orientalization in the castas paintings. It is not only that in his series there is an obvious presence of racial conflicts (one scene depicting violence (\# 15, De Genizaro y Mulata, Gibaro), and another - drinking and being drunk (\# 5, De Mulato y Española, Morisco)), but also he is the only known Spaniard who created castas paintings (Katzew 26). It is noticeable that the violence occurs in the Orientalized groups of the Genizaro and the Morisco, and possibly derives from the connotation of the violent nature of the representatives of the respective groups in the peninsula. It is important also that among the twenty four castas paitings depicting violence, selected by Emilia Guzauskyte in the four catalogues, four refer to the scenes with Genizaros, Chinos or Moriscos and several others to the offsprings of these racial mixtures (193-94).

114 Ilona Katzew and the other authors, citing her seminal work on castas paintings in eighteenth-century Mexico (Casta Paintings: Images of Race in EighteenthCentury Mexico), date this Francisco Clapera's series from the year 1785 (23). However, in the exposition of Denver Art Museum, this series is dated from 1775.

${ }^{115}$ Here one can have as an example the figure of la tapada limeña that became popular in the sixteenth century and into the early republican period, whose image reminded many of the Moorish influence in America.

${ }^{116}$ Very generally, the representation of racial structure of the Chino caste can be as suggested by León (20): 


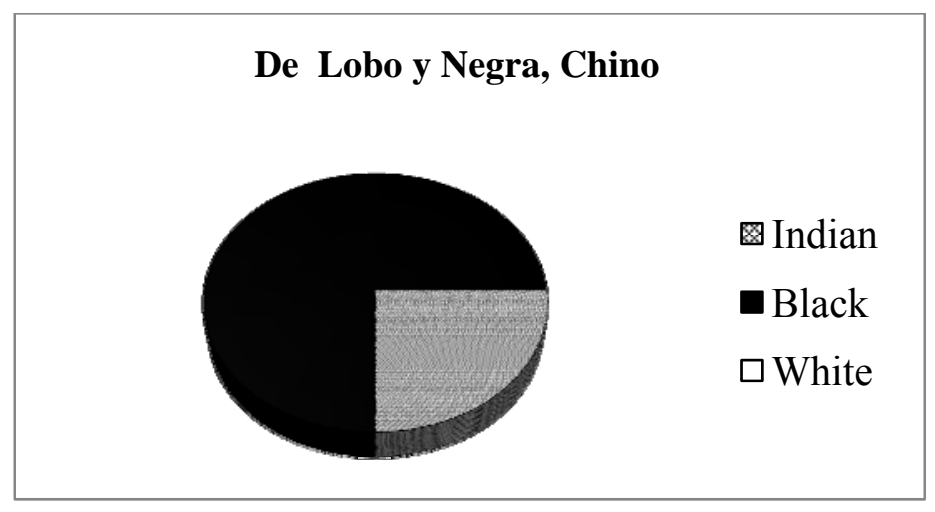

However, based on our analysis of the paintings, the actual representations of the Chino groups are much more complex. Based on the works analyzed could be summarized in the following table (based on the other paintings of the same series). Also, it is important to keep in mind that there are several other variations of the origins of the Chino group (see, for instance, No te entiendo con india, sale chino of Luis Berrueco). María Concepción García Sáiz, for example, points out the multifaceted nature of this group. She indicates that the Chino could be an offspring of the following parents: Lobo and Negra, Lobo and India, Mulato and India, Coyote and Mulata, Español and Morisca, Chamicoyote and India (26-27).

\section{The Chino group}

\begin{tabular}{|c|c|c|c|c|c|}
\hline Painting & Father & \begin{tabular}{|c|} 
Paternal \\
Grandparents
\end{tabular} & $\begin{array}{l}\text { Paternal } \\
\text { Great- } \\
\text { Grandparents }\end{array}$ & Mother & $\begin{array}{l}\text { Maternal } \\
\text { Grandparents }\end{array}$ \\
\hline \multirow[t]{4}{*}{ Clapera,\# 13} & Barcino & Mestizo & Español & Mulata & Español \\
\hline & & & India & & Negra \\
\hline & & Albarazada* & India & & \\
\hline & & & $\begin{array}{ll}\text { Lobo } & \\
\text { (Indio / Torna } \\
\text { atrás) }\end{array}$ & & \\
\hline \multirow[t]{2}{*}{ Islas, \# 10} & Lobo & India & & Negra & \\
\hline & & Negro & & & \\
\hline \multirow[t]{3}{*}{$\begin{array}{l}\text { Anonymous } \\
\text { (Museo del } \\
\text { Virreynato), } \\
\text { section } 8 \\
\end{array}$} & Morisco & Español & & Española & \\
\hline & & Mulato & Español & & \\
\hline & & & Negra & & \\
\hline $\begin{array}{l}\text { Cabrera, \# } 9 \\
\text { (China } \\
\text { cambuja) }\end{array}$ & Negro & & & India & \\
\hline
\end{tabular}


* I was not able to locate the painting \# 11, which might contain the information about Albarazado group. Therefore, I used the description provided in the painting of Miguel Cabrera, the most renowned among the painters analyzed here (\# 11, De Lobo y d'India, Albarazado) Other authors present their own variations: Gíbaro con Mulata, Albarazado (section 10, Anonumous, Museo del Virreinato); Tente en el aire y Mulata, nace Albarazado (\# 13, Islas).

${ }^{117}$ A similar process can be observed in the Morisco group. While the reference to the Moors (moros in Spanish) and the Morisco group in the Iberian peninsula are undisputable, García Sáiz offers another possible origin or, perhaps parallelism: "Morocho, ameneaus: "hard grained maize"; $19^{\text {th }}$ century, "a vigorous person," "darkskinned, swarthy"; perhaps from Quechua muruch'u, "something hard," "hard corn," 1560. But influenced by moro e moreno) (24). This is indicative of the fusion of Orientalization processes originated in Spain with the Orientalism in the Colony.

${ }^{118}$ María Concepción García Sáiz suggests that the parents of Genízaro could be Cambujo and China or Torna-atrás and India or Barcino and Zambaiga (26-27). This indicates the predominance of the Indigenous and African blood in the Genizaros. The in-depth analysis of their offsprings, such as Gibaros, can also cast light on the nature of Genizaro group and the role of Orientalization in its perception and denomination. See the following paintings: Clapera's \# 15 (De Genizaro, y Mulata Gibaro); Anonymous, Las castas (section 9, "Lobo con China Gibaro"); Anonymous, De china y mulato produce gibarao. The general racial structure by León suggests the following, which makes Genizaro racially closer to Barcino (20):

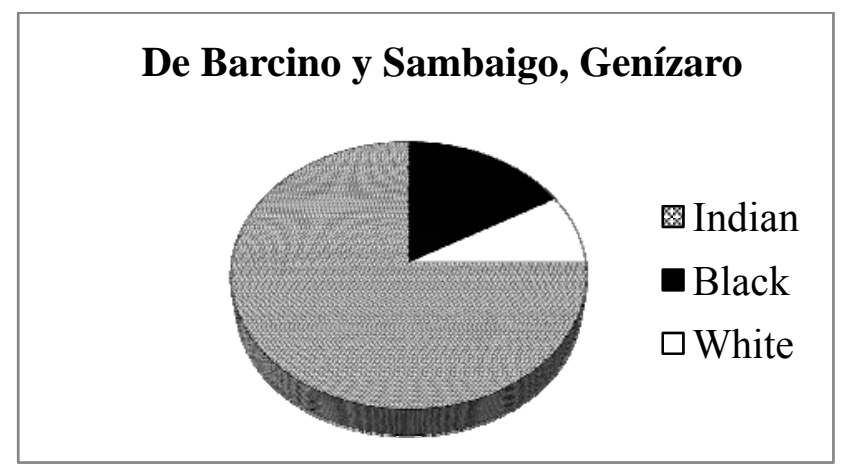

${ }^{119}$ The reason for selection of Christians was merely pragmatic. A Muslim in the same position was believed to be prompt to abuse his privileges. His relatives could be using his position to disobey local authorities, not paying taxes and event oppressing the peasants. At the same time, the Christian selectees, converted to Islam would be more zealous about their new religion and their new coreligionists (Kinross 147). The Janissaries, the elite sultan forces, became famous in the Christian Europe as a result of 
the numerous military campaigns of the Ottomans, as the one at Rhodes in 1522, when the Sultan Suleimans's fleet and army fought against European knights, Castile and Aragon knights being among them; or the campaigns that followed, such as the one in 1535 when the joint forces of Spaniards, Germans and Italians under the command of Andrea Doria disembarked in North Africa (Kinross 176-77, 220). However, towards the end of the sixteenth century, the Janissaries became more sedentary. They were allowed to work as artisan and receive profits from sales, as well as to get marry, which naturally affected both their discipline and warrior spirit (Kinross 285). Only in 1826, the Janissaries were officially abolished in Tanzamat (Regulations) of the Ottoman Sultan Mahmud II (1785-1839), as intent to modernize the army (Armstrong 150, 194).

${ }^{120}$ It is curios that in Facundo color, a crucial aspect for social segregation in the castas paintings is also used for differentiating the so-called civilization and barbarism. In Chapter 8, Sarmiento offers a long discourse on color and how it served as a distinction of Rosas's supporters. He then ties the use of color to barbarism, as it was used by barbaric civilizations, culminating his deliberations with a rhetoric question: “¿Es casualidad que Argel, Túnez, el Japón, Marruecos, Turquía, Siam, los africanos, los salvajes, los Nerones romanos, los reyes barbarous, il terrore e lo spavento, el Verdugo y Rosas, se hallen vestidos con un color proscrito hoy día, por las sociedades cristianas y cultas?" (Sarmiento, Civilización 122).

121 This dismal picture of Latin American barbarism echoes the descriptions of the first explorers and colonizers, whose Orientalized image of el buen salvaje populated European literature and long after the end of the Conquest.

${ }^{122}$ See translation for this quote:

The critics of Orientalism, starting with Edward Said, regarded the Oriental (with exaggeration?) as a projection, to which the Europeans attribute all the negative characteristics they do not want to be associated with their own image. It is a persistent error. The American, on the other hand, was a prototype of hombre natural, that later was going to ramify into many others; it was easy to transform and convert. This character had its precursors in Greek and Roman thought, as well as Arabic, but reincarnated in Europe after the first encounter with the primitive nations.

${ }^{123}$ Taboada finds natural the connection of the Orientalism and Americanism: .. no es extraño entonces que el primer americanismo haya derivado algunos temas del orientalismo. Más tarde la experiencia del mundo Americano llegó a crecer en tales proporciones que desplazó a los escritores turcógrafos en España, país que se iba a convertir en el centro del saber americanista (hasta el siglo XVIII) mientras iba descuidando los estudios orientalistas, al tiempo que París y Ovaina los creaban. El Turco 
y el Moro reinaron en la literatura española del Siglo de Oro a partir de 1580 , y desde esa misma fecha fueron desapareciendo de su ciencia. (228-29)

${ }^{124}$ However, as Stacie Widdifield notes:

With the move toward independence, the body of the Indian became the critical nexus in the discourse of origin and authenticity. The Indian of academic painting was constructed in a historical light as a complex "simulacrum of the Indian [with] the aura of an elite culture from which the present of the nineteenth century could claim a legitimizing descent. These nineteenth-century representations also contained the regulatory associations of casta references. Specifically, the use of neoclassicism also maintained the Indian as a figure that was the continuous object of conquest and westernization. (10-11) 


\section{CHAPTER 4.}

\section{The Differentiation: Hispanic Orientalism in Modern Latin America}

\section{$\S 1$. Introduction}

The geopolitical and social impact of Latin American independence can be compared to the aftermath of the Reconquest in Spain. A new power structure impacted the development of society, and naturally led to the revision of the traditional Other. ${ }^{125}$ As Walden Browne notes, "the rise of nationalistic sentiments in Latin America coincides with the growing desire on the part of its inhabitants to establish an intellectual foundation separate from Europe or the United States" (63). As had happened earlier in the Peninsula, these profound political changes had a strong impact on the modern Hispanic Orientalist paradigm. The decline of the Spanish Colonial Empire, partly as a result of "the Indies gone, prosperity done" process (Etemad 193), also factored into the reconsideration of a new position on the world arena by the newly formed Latin American nations.

The early independence period was marked by significant political and economic clashes, as violence and poverty went hand-in-hand. It is notorious, however, that until now, even the countries of Latin America that had enjoyed a wide variety of mineral and natural resources, such as Mexico, Peru, and Argentina among others, have experienced great economic difficulties. ${ }^{126}$ The period of independence in Latin America was also marked by the more or less violent rule of succeeding military regimes. They appeared not only during the process of formation and stabilization of sociopolitical processes in 
the young nations but continued to emerge in the twentieth century. The ideas and policies of the leaders who wore military uniforms when they came to power, such as Juan Domingo Perón (Argentina), Fidel Castro (Cuba), Augusto Pinochet (Chile), Hugo Chávez (Venezuela) and others, up until today affect popular thinking and the development of sociocultural relations in their respective countries. In his study on the relations between ex-colonizer and ex-colonized, Albert Memmi traces a parallel between the decolonization of Latin America in the nineteenth century and the Arab world in the twentieth, pointing out that military regimes played crucial roles in the history of both excolonized $^{127}$ defining their post-colonial relationships (Decolonization 15-17). While such regimes often may have appeared attractive in the beginning, their strategies for maintaining political power have proven detrimental for the nation.

As a result, Latin American independence failed to bring prosperity and peace, or to solve social and political conflicts. Often, it meant the change from one "master" to another rather than a change in the system itself. In his comparative analysis of decolonization in the North African Arabic countries and the Southern Cone, Albert Memmi traces an interesting parallel: "Naturally, it is reassuring for a people to be governed by leaders of its own; flattering to see their flag flapping in the wind in place of that of the colonizers . . . but, for majority, things haven't changed much. There has been a change of master, but, like new leeches, the new ruling classes are often greedier than the old" (Decolonization 3-4). Furthermore, Memmi points out that the educated and highly motivated members of the upper middle class (criollos, in the case of Latin America) were expected to "have taken care of the administration of national business matters in the interests of its people ... instead, this class exacted privileges for itself and 
developed a political and administrative system to protect them" (Decolonization 4). Tired of being underprivileged, the Latin American criollos, who now took the place of the colonial master, needed to legitimize their position, as the Spanish conquistadors previously had done. The new criollo elite would also have to revise the image of Latin America and the Amerindian in order to differentiate themselves from the former metropolis.

In this sense, the following assertion by Hernán Taboada about the arrival of Spaniards to the New World can be metaphorically applied to the Latin America that suddenly came to the realization of its new political role and place, and the deep similarities between itself and the former metropolis that it tried to overcome through differentiation: ${ }^{128}$

Cuando la civilización europea alcanzó más vigor y autoconciencia, atribuyó esta capacidad de redimirse mediante la imitación a la cantidad de otros pueblos, incluyendo, desde el siglo XIX, a los muslimes, pero el americano resultó ser el espejo llamativo y hacia él dirigieron crecientemente las miradas los europeos. Durante siglos, los varones de la Cristiandad latina se habían distinguido de los muslimes o los judíos por su ausencia de barba. Al arribar al Nuevo Mundo anotaron, acertadamente o no, que su modalidad lampiña era compartida por los amerindios, cuya escasa pilosidad empezó a convertirse en un rasgo básico de las descripciones. Que los europeos comenzaran a portar barba a partir del siglo XVI es un hecho, y en alguna medida, aunque con seguridad la causalidad no es tan directa, el cambio nos señala que el Otro por 
excelencia, del cual había que distinguirse, no era ya el judío/muslim, sino el amerindio. (Taboada 232).

As in the case of Spaniards, not so much the physical, but rather the cultural and sociopolitical resemblance of the former colony was perceived as an obstacle to the successful and independent development of the Latin American countries. As such, it is addressed through Orientalizing the self and the Other(s).

As the power rested in the hands of the people once considered "the product" of the New World and, hence, second class citizens, towards the beginning of the twentieth century there began a significant movement toward locating a new niche for Latin America in world history. As Marcel Merle suggests, the process of decolonization provoked "pasiones en lugar de reflexión" ("passions instead of reflexion"); however, once the tumultuous Independence period was over, the new nations felt the urge to "ascender hasta los orígenes de la aventura colonial para identificar las corrientes de pensamiento que la favorecieron y las que se opusieron" ("to get to the origins of the colonial enterprise to identify the ideas that favored and opposed it"; 13). So, as the states progressed and gained more recognition, their attention moved from the search for the external Other, as a means for differentiation, to the revalorization of the Latin American heritage. As such, the previous periods, both in literature and politics, are characterized by the virtual absence of an indigenous voice, unless it was represented in Orientalist fashion by, and served the interest of, the dominant group. Therefore, even though the colonial master has changed, the autochthonous population continued to be the Otherwithin of the newly born independent Latin America, often Orientalized and surrounded by a preconceived concept of their nature and self. With the exception of Benito Juárez in 
México, it is not until well into the twentieth century that we see influential figures of indigenous ancestry, such as Juan Evo Morales Ayma or Rigoberta Menchú.

These circumstances - the presence of the ethno-cultural group, overlooked or oppressed by the ruling class, on the one hand, and the historical memory of the ruling class itself as having been oppressed, on the other hand, as the former colonized defined Hispanic Orientalism in post-Independence Latin America. Already during the transitional period the authors of the New World started to look at the rest of the world, as well as into their own restructured society, for a new Other, against which to define the emerging nations. This process only intensifies into modernity as the threat of a new "reconquest" by the former metropolis diminishes.

The parallel with the historical past, once again, is not incidental. As Hernán Taboada notes, "antes de tener parlamentos, ejércitos y universidades de cartón pintado, tuvimos una Reconquista de cartón pintado; desde el Cid mucho habían cambiado los tiempos, aunque los hombres que llegaron a Indias no siempre lo vieran, dominados por algunas míticas ideas de lo ocurrido en la España medieval" ("before having puppet parliaments, armies and universities, we had a puppet Reconquest; a lot had changed since the times of the Cid, even though those who arrived in the New World were not always able to see it, possessed as they were by mythical ideas of what had happened in Medieval Spain"; 194). This parallel illustrates the continuity of Hispanic Orientalism as a dynamic paradigm that, despite its rather superficial shifts in actors and circumstances along its temporal and geographical journey, continued to project its political agenda onto modernity. So, as in the Renaissance with the Moors, Latin American nations in the twentieth century became more benevolent toward the internal/external Other. The 
difference in this perception is often marked by the desire for self-affirmation on the part of the newly independent state, which leads to a more favorable representation of the Other, and even its "veneration," as argued by Julia Kushigian.

Consequently, two main Hispanic Orientalist strategies result from the new political dynamics of post-Independence Latin America. Both of them served the purpose of differentiation through self-Orientalization. As Latin American nations moved towards their independence this need for self-assurance only grew stronger. During the postIndependence period, it manifested in further differentiation not only from the former metropolis, but from the other Others, including the Oriental (Asian) Other. One of these strategies is focused on the role of the outsider, and looks for the Other both in the traditional Orient and in Europe, the former colonizer. This approach is copiously reflected in twentieth-century literary works, for instance those of the representatives of the modernista movement.

This chapter looks into the search and the interpretation of the European/Oriental Other(s) in works by Enrique Gómez Carrillo: his modernista travel logs, such as Japón heroico y galante (1912), La Rusia actual (1906), and literary criticism as Literaturas extranjeras (1895). Also, we will analyze the relationship with the external Oriental Other in the short stories of Jorge Luis Borges. The selection of Borges's works allows for a dialogue with Kushigian's suggesion of a sincere veneration of the Orient in Hispanic Orientalism.

The other modern Orientalist strategy is focused on the image of the Amerindian self, previously Orientalized by hegemonic society. Erik Camayd-Freixas notes that “"orientalization' of Native Americans, which depicted them as foreigners in their own 
land so as to justify colonization, is a direct antecedent of modern Orientalist discourses about Latin America" (Controversy 1). Indeed, the shift of power in the New World called for the revision of the Eurocentric model and a push towards constructing a new perspective centered on Latin America. This leads to what Cristina Civantos defines as hispanismo, the reconciliation and the revalorization of the Spanish heritage in the Americas (27). It is carried out through self-Orientalization and the revalorization of the Other for the purpose of differentiation from the mentality and the political dominance of the former colonizer.

Silvia Nagy-Zekmi states that "la visión eurocéntrica de la escritura orientalista se construye a partir de esta misma distancia entre el Uno (self) y el Otro que se establece para impedir la realización del deseo del observador y para permitir que las cualidades negativas del sujeto se subrayen y lo atractivo se represente como un extraño elemento de una cultura incomprensible e impenetrable" ("the Eurocentric vision of Orientalist writings is based on this very distance between the self and the Other that is established to prevent the realization of the observer's desires and to allow for the exaltation of the negative qualities of the subject while presenting its attractiveness as a strange element of an incomprehensible and impenetrable culture"; 17). If so, Latin America-centered Orientalism inverts these elements, making the former hegemony "strange" and "incomprehensible," while attributing positive characteristics to the formerly Orientalized self.

This inversion of the roles is not new to Latin America. The switch of dichotomous elements is an Orientalist relationship that took place previously both in Renaissance Spain and during the Independence period in Latin America. In order to 
analyze this path of revalorization of the past, this chapter analyses the twentieth-century image of the Orientalized figure par excellence of Latin American history, La Malinche. It looks into the revision of her role during the Conquest, in Elena Garro's "La culpa es de los tlaxcaltecas." Confronted with the masculine stereotypical image of this legendary interpreter and the symbolic mother of mestizaje, Garro attempts to de-Orientalize her protagonist in an effort to revalorize colonial history.

In order to recreate the contemporary paradigm of Hispanic Orientalism, the approach of each of the above mentioned authors is analyzed in the context of previous Orientalist tradition. The goal and the outcomes of their Orientalist strategies, focused on self and the non-Latin American Other, are then compared in order to trace similarities among them, which ultimately allows for establishing the characteristics of Hispanic

Orientalism in the twentieth century. This allows us to define the paradigm for Hispanic Orientalism during the post-Independence period, when Latin America, the former colonized self, is striving to find its place in the modern world, in order to establish relationships with Europe, Asia, and North America, and at the same time to review its own sociopolitical order and the relationships between different classes and sociocultural groups (castes) within its own society.

\section{§ 2. Differentiation through Reinterpretation: The Traditional and the Non-Traditional Other}

The beginning of the twentieth century for post-Colonial Spain and Latin America was marked by two significant but opposite tendencies. By 1898, Spain lost its remaining 
overseas colonies as a result of the Spanish-American War, which negatively affected its image on the world's arena, as well as weakened its political influence. At the same time, the former colonies, emerging from the tumultuous process of national formation and having obtained a new political identity, felt more secure about the diminished colonial European threat. Under these new circumstances "early twentieth-century Latin America is known for its hispanismo, or Hispanism, a spirit of reconciliation with Spain that entailed a revalorization of Hispano-America's Spanish heritage" (Civantos 27). For Hispanic Orientalism it meant that its Eurocentric nature, which characterized the discourse of civilization and barbarism during the nineteenth and part of the twentieth century, was gradually giving way to a different approach (Nagy-Zekmi 18). Michel Foucault also argues that by the twentieth century, Europe increasingly looked for an outsider Other to help it reestablish its identity after the nineteenth-century turmoil (Les mots 339). Latin America did not fall short of similar aspirations. During the period when the image of the actual Orient as a threat was too historically removed to be preserved in the popular imagery, and Latin America was self-assured enough to move forward with its own version of Orientalism, it was the search for the new Other that marked modern Hispanic Orientalism.

At the beginning of the twentieth century while the search for the negative image of Latin America continued, many of the authors resorted once again to the Oriental Other. This approach fits substantively with the theory of Edward Said, whose "book became emblematic of the coherent criticism of the Western colonial enterprise in the Orient, and subsequently, in the so-called 'Third World,' by unmasking the creation of the colonial/colonizing discourse, which naturally forced upon us the idea of an exotic 
Orient" (Nagy-Zekmi, 14-15; my translation). This idea of the Orientalized exotic Oriental Other became immensely popular during the modern period. Araceli Tinajero in her book Orientalismo en el modernismo americano argues for this tendency for exoticism in the representations of the Orient in the works of Latin American modernista authors, such as Juan José Tablada, Efrén Rebolledo, Enrique Gómez Carrillo, Rubén Darío, Julián del Casal, and others. These authors not only refer to Oriental topics, they also experiment with Oriental literary forms. For instance, Juan José Tablada is the first Latin American poet to write haikus, as seen in his collection of poems Un dia (1919) (Whittingham 218). However, often their use of Oriental themes and forms was merely decorative: their search for an enhanced sensibility and their rejection of Western rationality forced them to reinterpret the Other (Camayd-Freixas, Tao 120).

This proposition, the exoticizing Orientalist approach to the Oriental Other, contrasts with Julia Kushigian thesis about the veneration of the Orient in the Latin American Literary tradition. While the abundance of Orient-related images is indicative of the interest in the topic, the quality of representation speaks to the curiosity of the authors and their admiration of the often pre-constructed image of the Other. Examples of this are the travelogues of Enrique Gómez Carrillo (1873-1927), a Guatemalan with deep roots in the European cultural and literary tradition. Born in post-Independence Latin America, only relatively independence economically and politically, Gómez Carrillo, using the terms of Rana Kabbani, felt that he was "the agent of the superior civilization" when he looked at the Orient. However, his exoticizing look is slightly different than that of the original Peninsular Orientalism. While reinventing the Other, he seeks selfOrientalization at the same time, as a way to differentiate his Latin American identity 
from that of the others. In his attempt to carry out this process, Gómez Carrillo refers to the notion of the proper Orient, as well as a broader approach to it, for instance, including images of Eastern Europe in his "Oriental" travelogues. This section analyses his Orientalized perception of the Other in his travel narrative and literary criticism, such as El Japón heroico y galante (1912), La Rusia actual (1906), and Literatura extranjera (1895).

The debate between the predominantly negative Saidian approach to Orientalisttype relationships and Kushigian's thesis about the veneration of the Orient in the Hispanic literary tradition is crucial for understanding the perception of the Orient in the narrative of the "errant chronicler" Gómez Carrillo. A Guatemalan writer, educated in Europe and proud of his European ancestry, Gómez Carrillo worked as a correspondent for both Spanish and Latin American newspapers, visiting numerous countries of the socalled Orient, from Russia to Japan and North Africa. But it is Japan and Japanese culture that seemed to attract his attention the most, possibly because of the widespread japonofilia in France, Paris being the center of the artistic world at the time (Whittingham 219). Ivan Schulman in his argument about the new modernista approach to Orientalism(s) also indicates that the Latin American representatives of this movement were strongly influenced by the nineteenth-century predetermined images of the Orient they encountered in predominantly French texts (96). He also indicates that the Hispanic World, familiar with the Arab Other, was looking into the exotic Orient rather than the Middle East. At the same time, the political and social turmoil in countries like China often prevented European travelers from visiting, whereas Japan, which opened to the 
Western world in 1853, presented an exciting opportunity for an Orientalist discovery (96).

Gómez Carrillo's travel writings were not an exception to this tendency. He dedicated several travel memoires to the description and analysis of the customs and traditions of Japan and its inhabitants, as well as Japanese literature: Literaturas exóticas (1920), El alma japonesa (1905), and El Japón heroico y galante (1912). But it is perhaps the latter work (Heroic and Gallant Japan) that best reveals Gómez Carillo's use of Hispanic Orientalism in nominally "post-colonial" Latin America. ${ }^{129}$ It shows an interesting blend between the ideologies of the former colonizer and the colonized in the mentality of the author, as a Guatemalan who spent his formative years in France. This influences his approach to the Other, as well as his perception and his interpretation of Japanese culture and lifestyle.

At the time when Gómez Carrillo visited Japan it had emerged as a victor over the Russian Empire. Its future potential, as well as its process of cultural modernization were at the center of Europe's attention. For Gómez Carrillo, the case of Japan was especially significant: its Westernization and modernization in the twentieth century echoed similar processes that Guatemala and Latin America as a whole were aspiring to at the turn of the century (Clark 111). Therefore, Gómez Carrillo's interpretation of this process, as well as his understanding of Japanese culture was tacitly influenced by the desire of selfidentification.

In order to understand the nature of Orientalization in El Japón heroico y galante, it is important to refer to Said's concepts of "strategic location" and "strategic formation." Their thorough understanding casts light on the position of the author with 
respect to the Other that he observes and interprets, as well as the position of Japan itself, caught between the process of Westernization and the desire to preserve its own culture. As Memmi states, "writers have a marvelous tool at their disposal, imagination, which allows them to make believe. They can attribute to fictional characters things they themselves feel and think" (36). Likewise, Gómez Carrillo creates his own image of Japan influenced by his beliefs and experiences. Similarly, his contemporaries, such as José Juan Tablada and other Latin American modernists build their own rather exoticizing visions of Japan (Chang Shik 100). Gómez Carrillo as well, in the words of Francisco Morán, "va en busca de un topos en el que Occidente ya ha envasado su mirada: . . el Oriente literario de las fabulas y las leyendas, de las sensaciones que persigue el modernismo" ("looks for a topos that the Occident has already established: the Orient of fairy-tales and legends, a feeling that is pursued by Modernism"; 394).

At the beginning of Gómez Carrillo's travelogue, he reports, disappointed, that the influence of Western civilization has spread to Japan. However, as he leaves Yokohama and heads to Tokyo, he finds more and more representations of his idyllic "Japón soñado" ("the Japan I dreamed about"; Japón 10). He is amazed and at the same time amused by the paradoxical combination of sadness and gallantry in Japan. Submerged in the world of elegant musme (meaning "girl" or "daughter" in Japanese), naïve and carnal "women of pleasure," oiran, and ancient samurai, he founds what he sees as the essence of Japan: a blend of tragic and heroic spirits displayed in front of his eyes in a solemn slowness. Gómez Carrillo finds these qualities not only in the glorious samurai, but even in the lowest classes and the least revered professions (in the eyes of a European traveler), as in the legend of "virtuosa oirán" ("virtuous oiran"): "En mi 
ignorancia, yo no sabía, hace pocas semanas, que una hetaira ... puede ser modelo de honestidad" ("In my ignorance, I did not know till recently that a hetaera could be a model of honesty"; Japón 27). He uses the legends, the poetry, and the events in contemporary texts to attest to his observations and add to the veracity of his narration. In his descriptions, Gómez Carrillo also pays special attention to Japanese realia, recreating an exotic atmosphere: kimonos, exquisite silks, magnificent screens, bamboo furniture, exotic hairdos; all of them shape the profile of his "Japón admirable" (“admirable Japan"; Japón 12).

As a result, Gómez Carrillo sees Western influence on Japan as menacing and destructive. He concludes his analysis of the Westernization of the country with the following words: "la miseria tal como hoy existe . . . es una fatal consecuencia de la influencia europea" ("misery in its current state is the fatal consequence of European influence"; Japón 204). Furthermore, he declares that this pernicious and distructive influence is dangerous not only for Japan, but also for the whole world, as it diverts this Oriental giant from its historic mission: "Las civilizaciones de todos los países deben reunirse en el Japón; y el Japón transformará estas civilizaciones por su influencia propia y dotará al mundo de una civilización única y verdadera. Esta es la misión particular del Japón" ("The civilizations of all countries should meet in Japan; and Japan will transform these civilizations through its own influence and give the world a real and unique civilization. This is the actual mission of Japan”; Japón 100).

The tacit comparison with Latin America here is pivotal. In the post-Colonial period, the new nations were at the crossroads of civilization: they had to choose whether to continue with the European traditions brought by the conquistadors or to go back to 
their pre-Colombian roots. By creating such parallelism with Orientalized Japan, Gómez Carrillo calls for revalorization of the past for the sake of differentiating the independent Latin American self that is being "destroyed" by Westernizing influence. This is a crucial aspect of modern Hispanic Orientalism; the call for the revision of the Orientalized past becomes only stronger as Latin America faces more political and cultural challenges in the twentieth century.

In this light, the image of this country created by Gómez Carrillo seems to be rather distant from the traditional Saidian negativism. The author praises the national character, both in men and women, openly admires the Japanese past and present. He singles out Japan among all other Oriental countries he visited and seems sympathetic to its historic mission conveyed to him by the locals, and found in the legends and myths of the country. However, does his view entirely follow Kushigian's positivist definition of Hispanic Orientalism and is Gómez Carrillo's approach a true and sincere veneration of the real Japan? In order to answer these questions it is important to go beyond the superficial descriptions of the country and its traditions and analyze the broader context in which they are given.

First and foremost, it becomes obvious to the reader from the very beginning that the travelogue purports to be written from a European point of view or is aimed at a European audience. This can be seen in multiple mentions of Europe and European artists and writers found on the pages of Heroic and Gallant Japan. In the first paragraph, a synthesis of the travelogue, Gómez Carrillo describes Japanese reality as "no como en Europa" ("not like in Europe"; Japón 10). Hence, the starting point for his observations is Europe and the Other is measures against its traditional values. One can attribute these 
numerous references to the European history, literature and culture to the fact that Gómez Carrillo saw his audience as primarily European. But even so, their abundance and their recurrence, and at the same time, the lack of references to Latin America (there are only three or four in the whole text) is indicative of the imperative desire of the Guatemalan writer to take advantage of the hegemonic discourse; therefore, it is natural to expect that he would use it in his narrative. Such supposition can explain why Japan interests him so much. Its ambivalent position between its glorious past and Westernized present echoes the personal dilemma of the author, caught between the Latin Americanism of the former colony and the Eurocentric approach to the Other of the former European colonizer. Gómez Carrillo has to reimagine himself first in order to reimagine the Oriental Other. In this sense, he follows Kushigian's argument about self-Orientalization as an integral part of Hispanic Orientalism.

Secondly, viewed through a European lens, the image of Japan cannot but undergo a process of reinvention. Gómez Carrillo arrives at this country, as he himself attests, looking for a Japan that he was dreaming about, to find "qué le falta a este Japón, en el que vivo desde hace algunas horas, para ser mi Japón soñado" ("what this Japan that I am living in for the past several hours lacks to become the Japan that I dreamed about"; Japón 10). His descriptions of the local customs and traditions are always carried out in comparison to European ones: "Los europeos llaman a Utamaro el pintor de las casas verdes" ("The Europeans call Utamaro the painter of green houses"; Japón 41), "Cree Usted que hay un occidental célèbre capaz de hablar así? Uno hubo . . . Se llamó Próspero Mèrimée" $\langle s i c>$ ("Do you believe that there is a famous Westerner able to speak like this? There was one. His name was Prosper Mérimée"; Japón 41), "El miedo a 
la muerte, este miedo que domina al Occidente, no ha invadida aún el Japón" ("The fear of death, this fear that dominates the Occident, has not yet invaded Japan"; Japón 135). These strong European bonds and the use of Europe as a reference are indicative of the fact that the appreciation of Japan's self and culture is carried out from the standpoint of the Occident. This reveals that despite the author's respect of the Other, its image is redrawn using European patterns, in other words, Orientalized. It is appreciated but its value is measured using European scale.

It is also indicative of Gómez Carrillo's Orientalization that it does not always take the form of an open and premeditated Europeanizing hegemonic discourse. While there are only few direct comparisons to Latin America in Heroic and Gallant Japan, there are various metatextual references to the New World and tacit comparisons of Japan and Latin America. Their significance lies, however, not only in the fact that such comparisons are silenced by the author, but in their nature. For instance, Gómez Carrillo describes the differences in Japanese referring to the notion of castes in Latin America, and even describes the lower class Japanese women as "lo mismo que las indias de América" ("same as Indigenous women in America"; Japón 20). This is especially peculiar in light of the fact that the castas painings, the representations of the castes popular in colonial Latin America, were banned in 1822 in Mexico for their discriminatory nature.

Another important metatextual comparison between the New World and Japan lies in the description of their religious practices and honor code. When describing hakakiri, the ritual suicide of the Japanese worriers, Gómez Carrillo notes that "sacrificio de la existencia como ... acto natural" ("sacrificing one's existence is a natural act"; 
Japón 49). It is this and other similar practices of the honor code and even everyday life that contributed to the grandeur and the gallant heroism of Japan's splendid past. This cannot but raise the argument about the role of the colonizer in the process of the conquest of the Aztec Empire and its impact on (paraphrasing the words of Bernardo de Balbuena, la grandeza latinoamericana) the Latin American grandeur and its history. The Orientalized image of Japan, thus, allows Gómez Carrillo to tacitly review the Latin American past without calling for such revision openly, which might not be welcomed by his contemporary readers from both Europe and Latin America.

But perhaps, the most indicative of Gómez Carrillo's Orientalization, as well as self-Orientalization is the reference to the wide-spread mito del buen salvaje (myth of the noble savage). Popularized in the chronicles of the first explorers and conquistadors, it originally described the indigenous population of the Americas as the naïve and lost children of the true faith, which later allowed for the religious campaigns and Christianization. Gómez Carrillo uses similar imagery to describe the contemporary Japanese, whom he sees as the lost children of a great civilization that is disappearing under the European pressure. The author is surprised by their shameless nudity, their harmonious living with nature, but at the same time their sins, their view of women divided into progenitors and prostitutes, and their inability to distinguish between good and evil, as in the case of oiran who are often surrounded by "aureola de perfecciónes" $<s i c>$ despite their not so noble profession ("halo of perfection”; Japón 39). He uses even more direct references to the myth, so deeply embedded in the perception of the Amerindian Other, when referring to the looks of the Japanese: "sin más traje que un taparrabos, un simple taparrabos de salvaje" ("wearing no more than a loincloth, the 
simple loincloth of a savage"; Japón 14). This comparative self-Orientalization plays a crucial role in Gómez Carrillo's political agenda. Without it, a process of differentiation would not be complete.

According to Kushigian, Hispanic Orientalism lacks imperial aspiration, which is what makes it able to comprehend and appreciate its Other. For her, Hispanic Orientalism "reflects not so much a political posture towards the Orient ... rather, a more thoughtful approach that values the dialogue of discourses, reflecting an antithetical denial of and openness to the Other ... providing an enriching discourse that does not seek to exercise social or political control over the Orient" (10-11). However, this is not entirely true in the case of Gómez Carrillo. While his goal is indeed not to control the Other, his dialogue with the Orient is not as open or as direct as Kushigian suggests. While she insists that the positivism of Hispanic Orientalism is the result of the yuxtapositional and nonhierarchical structure of the relationship with the Other that is reflected in its openendedness and polyglot nature (14), the Eurocentric approach to the image of Japan plays an important role in Gómez Carrillo's narrative. Even when he uses it as a mechanism to call for the revalorization of the Latin American past, the fact that he is forced to do it is significant. As such, the relationships between the observer and the Other are not entirely non-hierarchical. The Orient is portrayed and judged from an outside's perspective, which in case of Gómez Carrillo is complicated by his selfOrientalization.

Gómez Carrillo uses similar Orientalization tactics not only when addressing the proper Orient. In his critical essays and travel logs, he seeks to analyze a broader Other in order to highlight the uniqueness of Lain America's historical and cultural path. For 
instance, he refers to the images of Europe, especially Eastern and Northern Europe. Multiple times, he comes back to the image of czarist Russia, and the image of this nontraditional Other reveals his Orientalist approach that might not be as obvious in the case of the Orient proper, whose Orientalized traits became almost canonical by the beginning of the twentieth century.

As in case of Japan, Gómez Carrillo refers to the image of Russia, its history and culture on multiple occasions. He analyses the historical trajectory of the country in $L a$ Rusia actual (1906); while in Literaturas exóticas (1920) along with other authors from Eastern Europe (Albania, Montenegro), North Africa (Tunisia) and Asia (Corea, China, Japan) he analyses El rey de los judios, a sacrilege play that he attributes to Grand Duque Konstantin Romanov (see chapter "Un drama evangélico ruso"). In his earlier critical essay, Literatura extranjera (1895), he dedicates two chapters, respectively, to a Ukrainian-born Russian woman writer, Maria Bashkirtseva, and to the major Russian poet Alexander Pushkin, whose African roots were well-known. ${ }^{130}$

The very fact that the Slavic Empire became the center of Gómez Carrillo's attention is significant, especially in the light of Russian-Japanese conflict and the attack of Port Artur in 1904, and the might of these two world powers (Torres 153-54). The image of imperial Russia (1721-1917) that extended over Europe and Asia, with the Urals as a symbolic frontier between both worlds, resulted very attractive for the Guatemalan writer: formed as a result of the process of consolidation of its relatively developed European part and Asian (Siberian) wilderness, it was conquered and explored much like Latin America in the early Colonial period. On the other hand, it served as a reminder of 
the metropolis, the country where nunca se ponía el sol ("the sun never goes down") and whose mythical natural treasures became legendary in Europe.

This duality and, at the same time, the similarities between Russian and Latin American colonial history served Gómez Carrillo as a basis for his revision of Latin America's future and its position in respect to the old metropolis. The geographic position of the Russian Empire, two thirds of which were located in Asia, contributed to its easy inclusion in the often diverse and multifaceted group of "Orientals." On the other hand, the Russian Empire was seen for a long time as the Other of Europe, barbaric and wild compared to the "civilized" Old World, much like Latin America in its relation to Spain. Gómez Carrillo embraces the opportunity of rescuing the image of traditional Russia from oblivion through the Orientalization of its image, which could allow for the revalorization of the past in the New World.

At the center of Saidian Orientalism lies the thesis that it is customary that a dominant culture "actively makes place in it for a foreign Other" through the process of Orientalization that includes attributing to it all negative or unwanted characteristics (xxv). Gómez Carrillo, who oscillated between the Eurocentric sociocultural traditions that Orientalized Latin America in the first place, and the former Colony's quest for differentiation, skillfully uses this duplicity to disguise his criticism under the mask of traditional Eurocentrism. His approach to the image of Russia, similarly to the previous case of Japan, combines the two Orientalist approaches. It is not a coincidence, that Gómez Carrillo included the chapter on Cuban-born French poet José María de Heredia in the same volume where he theorizes about Russian literature and the role of Alexander Pushkin. 
Gómez Carrillo resorts to the image of the Russian Empire multiple times. In his travelogue, La Rusia actual, he describes its land and its capital at that time, St. Petersburg, along with the other "Oriental" cities and countries (from a European point of view): India, Shanghai, Damascus, Athens, Tokio, and others. In his literary criticism, he claims to rescue from oblivion the names of certain writers unjustly forgotten by mainstream European society. However, very often, these images have a certain exotic appeal: they are often the Others opposing the dominant literary tradition or transgressing social boundaries, like Maurice Barrès or Carmen Sylva, the Romanian queen-artist, or Alexander Pushkin, the most significant Russian poet whose rebellious and elegant poetry and prose reformed not only national literature but the language itself. In order to revalue and rescue their image, and as a result, to validate the Other, Gómez Carrillo cannot but use the same technique that Orientalized it in the first place.

Sharpened by exoticism, in the words of Ivan Schulman (105), Gómez Carrillo's Orientalism, however, serves a different purpose. Indeed, it would be erroneous to assert that Gómez Carrillo's Orientalism is only disguised or shrouded in European tradition. "Un verdadero hijo de Francia" ("a true son of France") according to Julio César Anzueta, he shares the European taste for the exotic, predominantly in Oriental cultures (46). One of the most vivid examples of this is his very publicly discussed relationship with Mata Hari. That said, Gómez Carrillo's Orientalism still kept a certain distance from the Reconquest and even the Conquest tradition, as he was more aware of the negativism of the exclusivist position of his predecessors. As such, he praises Emilia Pardo Bazán's efforts to rediscover Nordic literature for the readers in Spain and Europe. His Literatura extranjera shows the oscillation of Gómez Carrillo between the hegemonic and the 
subaltern cultures: on one hand, he praises contemporary French literature, on the other, he brings to life the literary works of Nordic authors - Swedish, Norwegian, German, English, and Russian.

Gómez Carrillo himself admits that, for many, there is still a "misterio exótico y lejano," something that explains why "nuestro entusiasmo por las letras eslavas es apasionado" ("exotic and remote mystery"; "our passionate enthusiasm for Slavic literature"; Gómez Carrillo, Crítica 65). His "alma irónica de comentarista marginal" ("ironic soul of a marginal commentator"), his personality, which was often compared to Jules Verne's or Gustavo Aymard's, allows Gómez Carrillo to have a fresh look at old facts (Ugarte 134, 138). However, despite his awareness of the imperfections of an Orientalist glance at the Other, he cannot avoid it, partly influenced by the dominant tradition, partly because it was the only literary weapon he knew he could effectively use to achieve his goals.

As such, the brief analysis of the trajectory of Russian literature in Western Europe that precedes his analysis of the life and literary legacy of Alexander Pushkin (1799-1837) in Literatura extranjera is a brilliant example of reinterpretation. Unlike his predecessors, Gómez Carrillo is more aware of this Orientalization, which he carries out through his manipulations of perspectives and historical facts. Hernán Taboada notes that the Hispanic world, in the absence of an Islamic threat, centers its attention on the exoticism of the Other (56). Similarly, Russian literature sparked curiosity in the European mind as long as it remained in the periphery and did not significantly interfere with it. "La fijación de una frontera hasta entonces cambiante" ("fixation of the previously unstable frontier"), in the case of the Russian and Spanish Empires vis a vis 
the "Turkish threat," started to take shape by the end of the eighteenth century (Taboada 173). This crucial moment of the rise of the Northern power that coincides with political and social reforms, along with the military victories of Catherine the Great (1729-1796) in the South, is a period of especial interest for Carrillo, not only because of its temporal proximity to the Independence of Latin America, but also because of the ideological significance of this period when Russian national identity was being formed. This is what possibly made it so convenient for the revision of the Latin American Orientalized image proposed by Gómez Carrillo.

The introduction to his essay on Pushkin at first seems to be extremely rational, thus denying the Orientalist approach. The author is ironical towards nationalistic writers and critics: "los profesores de las Universidades nos hablaron ... de herencia grecolatina, asegurándonos que sólo lo ligero y lo elegante podía florecer bajo el sol del Mediodía"131 ("university professors talked to us about Greco-Roman legacy, assuring us that only the subtle and the elegant could prosper under the Midday sun"; Gómez Carrillo, Crítica 66). He seems to mock the secular stereotypes of such interpretation: "todo lo que el extremo Septentrión nos envía es odioso; los rusos son cosacos, y los cosacos son los hijos de la nieve y de la bruma ... Al principio casi llegamos creer en la verdad de tales razones" ("everything that is sent to us from the far North is detestable; the Russians are Cossacks, and these are the children of the snow and the mist... At first, we might almost believe in the truth of such arguments"; Gómez Carrillo, Crítica 66). This, along with the abundance of dates and historical references should assert the trustworthiness of the narrative. 
Nevertheless, other than this brief introduction, the rest of the text is an example of Orientalist manipulations, as a result of which the historical Pushkin gives way to an exoticized image, well in line with the traditional Orientalized images of the Other. As Juan Mendoza notes, "bien sabía él que el hombre de carne y hueso conmueve más que la sombra; sabía también que la caricatura es risible, pero comprendió al mismo tiempo, que el retrato auténtico es otra cosa;" so he makes his protagonist take part in "una existencia real por la vitalidad de la exactitud que les imprimía" ("he very well knew that man of flesh and bone affects us more than his shadow; he know that caricature is laughable, but at the same time he understood that an authentic portray is a different thing"; "a real experience because of the vitality of its image's precision"; 310-11). As in his other essays, Gómez Carrillo chooses "un ambiente cultural generalizado, que propiciaba su temática, que adoptó sin reservas" ("a culturally generic ambience that favored his topic, which he boldly implemented"; Gutiérrez 414). This allows him to easily manipulate historical figures by transforming them into literary characters.

As such, the biographic account of Alexander Pushkin's life appears Orientalized bearing more resemblance to the plot of a novel than to a historic figure. Only to the reader familiar with the poet's life and works does it become soon evident that Gómez Carrillo traces a parallel between the romantic protagonist par excellence of Eugene Onegin (1823-1831) and his author. Despite the fact that his novel in verse bears some resemblance to Pushkin's life, the Guatemalan writer makes these similarities absolute, which results in significant historical errors and misinterpretations. The romantization and Orientalization of the poet is carried out in similar fashion to the figure of Abencerraje in early post-Reconquest Spain. Pushkin's life, his infancy and his literary 
career seem to be at the center of such transformation. Impoverished noblemen, the Pushkins were able to place young Alexander in the famous Lyceum of Tsarskoe Selo opened recently for the purpose of the education of the golden youth of the Russian capital at the time, St. Petersburg. The phantasmagoric imagination of Gómez Carrillo transforms them into "nobles cortesanos a quienes la vida en el palacio les impedía consagrar diariamente algunas horas a la educación del niño" ("noblemen whose life in court prevented them from dedicating several hours daily to the education of their son"; Gómez Carrillo, Crítica 67). Some factual mistakes also take place, as it seems that, according to Gómez Carrillo, Tsarskoe Selo was located close to Moscow.

Alexander Pushkin's fame and influence on Russian literature is defined by his elegant and agile poetry and prose. It is of no surprise then that the reinvention of this figure is centered around his creative work. Gómez Carrillo, once again, as in the case of Japan, introduces two opposite forces that fight for dominance. It is the deep influence of French tutors and his Russian nanny that allows Pushkin to understand that "su fantasía septentrional necesitaba versos amplios, robustos y tiernos, que el francés no podía darle" ("his Nordic fantasy needed ample, robust and gently verses that French could not provide"; Gómez Carrillo, Crítica 69). Gómez Carrillo theorizes and reinforces this idea by referring to the theory of "idiomas nórdicos," quoting Prosper Mérimée and others who believed that "el ruso parece hecho para la poesía" ("Nordic languages"; "Russian seems to be made for poetry"; Gómez Carrillo, Crítica 70). Once again, the revision of the Other brings the Guatemalan writer to the same conclusion: the necessity to revalorize the Latin American past that, as in the case of the life and legacy of Pushkin, was unjustly misunderstood and forgotten, and declare its uniqueness. 
To reinforce this idea, Gómez Carrillo goes even further by Orientalizing, as does Sarmiento, the "barbaric" and opposing it to the "civilized" Europe:

Los idiomas del Norte, por el contrario, parecen hechos para expresar sentimientos llenos de intensidad nebulosa. El choque frecuentísimo de las consonantes, la gran libertad de los giros y el sonido prolongado de algunas palabras, se prestan para expresar con nobleza cosas que en italiano, en francés o en español parecerían ridículas. El ruso tiene todas las cualidades de los dialectos bárbaros, con algo, además del movimiento armónico de los idiomas meridionales. (Gómez Carrillo, Crítica 69-70; my emphasis)

The languages of the North, on the contrary, seem to be created to express feelings filled with nebulous intensity. Very frequent clash of consonants, great freedom of order and prolonged sound of some words are fitting to express in noble way things that in Italian, French or Spanish would sound ridiculous. Besides the harmonic flow of Southern languages, Russian also has all the qualities of the barbarous dialects.

Such descriptions attest to the existence of the two antagonistic entities, the self and the Other, even on the semantic level. Both Pushkin and the Russian language, which was later greatly influenced by the poet, are perceived as the Other, albeit closely linked to the European dominant self. These Orientalized mirror images, like the images of Abencerraje and Narváez in post-Reconquest Spain, establish the external and internal 
connections between the two entities revealing a complex nature of their interactions. ${ }^{132}$ However, the reinvention and reinterpretation of the Other and its comparison to the dominant society is not carried out in the same way. It is done by "a third party," the former Other; thus the aim is not appropriation of the Orient by hegemonic society, but revalorization of the self, a self-(de)Orientalization or differentiation. This marks the difference between the original and the modern paradigms of Hispanic Orientalism.

Having justified his linguistic preference for Pushkin, Gómez Carrillo only reinforces his barbaric image, emphasizing the parallelism between the Russian and Latin American Others. Pushkin appears for the reader as a wild, arrogant, and selfish copy of the protagonist of Eugene Onegin. As in the case of the poet's education and language preferences, he does not disclose the real reasons for Pushkin's multiple exiles caused by his political disagreements with the government: such was the case of his support of the Decembrists, the participants in the first revolt of the nobles against the tsar in 1825 . Many of them were exiled to Siberia without the possibility of appeal or return to St. Petersburg, ${ }^{133}$ but Gómez Carrillo's Orientalizing imagination draws a different, more vicious picture: "embriagado por los primeros triunfos . . . metióse en política, compuso epigramas ... la justicia se enteró del asunto, y después de hacer un largo análisis, tuvo a bien considerar que el poeta necesitaba un baño de nieve para que se calmasen sus ardores líricos: le mandó a las montañas del Cáucaso" ("intoxicated with the first triumphs, he got involved in politics, composed epigrams; the justice system learned about this case and after long considerations, decided that the poet needed a snow bath to calm down his lyrical ardors: they exiled him to the Caucasus"; Gómez Carrillo, Crítica 71). Several stereotypes about Russia agglomerate here, like "un baño de nieve" that 
paradoxically refers to one of the best hot spring resorts of the Russian Empire. Almost satirical is the reference to "largo análisis," especially in the light of other of Gómez Carrillo's comments about Russia, like: "no hay en el mundo entero un ser tan caricaturesco como el empleado moscovita" ("in the whole world, there is no more caricature figure than that of the Moscow clerk"; Gómez Carrillo, Impresiones 213).

These circumstances, according to Gómez Carrillo, only instigate the rebellious nature of Pushkin whose life becomes "orgía elegante y sinfín;" his image becomes not only metaphorically but literally barbaric: "La sed de amar y ser amado le abrasa el pecho ... su pelo de cautivo, corto y vulgar, crece fantásticamente en su imaginación y cubre el rostro de las enamoradas increíbles ... ninguna sombra femenina le es indiferente" ("endless elegant orgy"; "the thirst of love and to be loved was burning in his chest, his hair of a prisoner, short and vulgar, grows fantastically in his imagination covering the face of his amazing lovers; he does not miss a single female shadow"; Gómez Carrillo, Critica 71-72). This transformed image of the poet is culminated with the translation of his poem about the encounter of a disturbed poet with a seraph. ${ }^{134}$ This oscillation between the hegemonic "civilized" and subaltern "barbaric" becomes even more intricate at the end of the essay, when Gómez Carrillo creates an idealistic scene of Pushkin's rescue by European literary tradition: "Durante el destierro, Pushkin no tuvo más consuelo que los libros de Byron" ("during his exile, Pushkin's only consolation were the Byron's books"; Gómez Carrillo, Crítica 71). However, even the literary figure chosen for Pushkin's comeback is a renowned Orientalist, famous precisely for his romantic reinterpretation of the Other. 
For Gómez Carrillo, it is this Byronian influence that makes Pushkin the national poet of Russia. In the same way, the Moorish protagonist who supports and shares Christian and monarchical values in Abencerraje or Guerras civiles de Granada becomes a part of the hierarchical societal structure. Nevertheless, both in the case of the Moorish prince and the Russian poet, the Orientalized Other occupies an inferior position (Lumsden-Kouvel 103). This is probably the reason why Gómez Carrillo shows no interest in the violent and typically romantic death of Pushkin in a duel defending the honor of his wife, Natalia Goncharova, considered the most beautiful and elegant lady in St. Petersburg, among whose admirers was even the Tsar Nicolas I. ${ }^{135}$

Finally, in the selection of the figure of Pushkin for his essay, it is hard to overlook the deep Oriental connections of the poet. His great-grandfather, an African slave, was given as a present to Peter the Great, and was known in Russia as an arap (Arab, in its translation from nineteenth-century Russian). Even in his appearance, Pushkin bears a resemblance to his ancestor. So does his Orientalists works, like The Prisoner of the Caucasus (1821), The Gypsies (1824), The Fountain of Bakhchisaray (1823), The Journey to Arzrum (1836), and others. Thus, the image of Pushkin, much like Latin America, was already Orientalized by hegemonic society, making his figure even more convenient for Gómez Carrillo.

In conclusion, in his effort to transmit the exoticism of Oriental culture, along with a description of traditional life and customs, Gómez Carrillo often Orientalizes both the proper as well as the less traditional Oriental Other like Russia or Romania. His Latin American background, influenced by the European paradigm of the relationship with the Other, determines his perspective. His depictions of the reality of the Other and his 
reinterpretation are carried out for the purpose of manipulating the existing linguistic and cultural stereotypes. By reviewing the past and the present of the Other, Gómez Carrillo asks the reader to revalue their ethnic and cultural singularity, thus calling for their differentiation from the traditional hegemonic power. Consequently, this serves him as a platform to claim the revalorization of Latin America, an idea that he tacitly introduces through bold but scarce comparisons. He uses typical Orientalization mechanisms such as reinterpretation and reimagination, but for a new purpose: to differentiate the earlier Other from the dominant power.

While Gómez Carrillo's Orientalism lacks Saidian negativism, it still carries out his assessment of the Other from the standpoint of hegemonic European civilization and its achievements. Both his essays about Russia and Japan reveal his interest in local history and culture. However, the image created and praised by Gómez Carrillo in his travelogues is somewhat different from the real one. In order to effectively carry out his agenda, Gómez Carrillo constructs it from preconceived ideas and expectations about the Oriental Other, which find their echo in history and folklore. In this sense, Gómez Carrillo's Orientalism occupies a middle ground between Said's and Kushigian's formulations. This allows the author to distance himself from the Other, but at the same time to appreciate the Orient for its Otherness, without appropriating it, as it happened in the case of Hispanic Orientalism during the Medieval and the Renaissance periods when hegemonic culture was under an immediate threat by the Other. 


\section{§ 3. The Search for Latin American Identity in the Oriental Mirror: The Forking Orientalism of Jorge Luis Borges}

Towards the mid-twentieth century, the exoticizing image of the Orient in Latin America, which prevailed at the beginning of the century, was gradually transformed into a more multifaceted and perhaps less fabulized representation. Erik Camayd-Freixas finds that this "evolving nature of this [Oriental] influence" is profoundly related to the authors' "deepening understanding of Latin American affinity with the East" (Tao 119). Indeed, several parallels can be traced between Latin America and its history and that of the traditional and non-traditional Orient. Like the Moors at the time of the Christian Reconquest in Iberia, Latin Americans became a new Other. Similarly, their independence from Spain raised the need to "exorcise the ghost of its own mestizaje" that resulted in "anxiety about the perceived lack of purity, religious and political unity, and even orthodox Christianization" (Majid 161). In the twentieth century, the search for national identity led to almost an obsession about the question of Otherness and its role in the formative process of Latin American nations.

In this process, the concept of the Orient is used as a canvas, on which the authors draw their own theories of Americanism. Rosario Hubert points out that toward the second part of the century there is an increasing number of literary works that take place

outside Latin America, especially in places traditionally considered as "Oriental." She notes that in the new era of global migration, immigration, and exile, "the new cartographies of fiction ... transcend what is considered - or expected - to be Latin American." These writers aim for a more global approach, so that the "new narrative 
geography is not necessarily linked to the historical contingency of the writer but has to do instead with deliberate aesthetic and political gestures" (Hubert 43). This marks a more global approach to both the Latin American as well as the Oriental Other. In such circumstances, mere exoticism would not be enough to address the question of the Other.

On the other hand, within the criticism there exists an alternative approach to modernism. Some, as does Francisco Morán, suggest that there exists another perspective of the Other parallel to the exoticizing trend developed during that period. This so-called anti-Orientalism was based on the perception of the Oriental subject as "un cuerpo extraño en el cuerpo de la Nación, y como constitutivamente decadente, tanto en el sentido físico como moral. Esa decadencia representaba, ponía en peligro - y cuestionaba desde dentro - el vigor de la Nación, en particular, y de América Latina, en general” (“A foreign body within the body of the Nation, structurally decadent both physically and morally. This decadence represented, endangered, and questioned from within inside the vigor of the Nation in question, and Latin America in general”; Morán 385). From this point of view, traditional modernism for Morán appears to be exported from the former metropolis. As such, it could not be used to address the question of Latin American national identity, and a new Orientalist approach needed to be found.

In light of this, it is not surprising that modern Orientalism is indebted to Romanticism (Nagy-Zekmi 19). It relies on the riotous image of the Latin American Other in its search for its real self. It is not accidental that many find parallels between the nineteenth-century Romantic and twentieth-century works. For instance, Marina Kaplan argues that Facundo should be "read as a work of fiction, which resembles a romance more than it does a novel," tracing parallels with the literary legacy of Jorge Luis Borges 
(316). The authors in this process, paraphrasing the words of Rosario Hubert, "do not exoticize the Oriental but instead use the Oriental setting as a rhetorical device to discuss the notion of exoticism, that is, the treatment of any cultural particularity as distant and fixed" (Hubert 48). This approach allows for an easy parallelism between the traditional Orient and Latin America, something that the authors started to take advantage of already at the beginning of the century, as for instance in the works of Enrique Gómez Carrillo.

In this context, the works of Jorge Luis Borges (1899-1986), who systematically used the image of the Orient in his writings, is emblematic of modern Orientalism. In her research on Hispanic Orientalism, Julia Kushigian extensively studies Borges's legacy and concludes that his Orientalism is characterized by a polyphony arising from the Hispanic Orientalism's polyglot nature that allows for a dialogue between the East and the West (Orientalism 26). She then includes the representations of Borges's Orient into the positive paradigm of Hispanic Orientalism marked by a sincere veneration of the Other and its recognition by mainstream culture. Similarly, Kushigian uses the works of Severo Sarduy and Octavio Paz to exemplify her thesis. However, such reading of modern Hispanic Orientalism can be seen as unilateral and often does not address the complexity of the historical relationship of the Hispanic world with the Oriental Other. Neither can it be applied to all the stages of development of Hispanic Orientalism.

Rubén Gallo in his analysis of Mexican Orientalism criticizes Kushigian's theory and opts instead for Said's approach:

Though useful in thinking about writers like Sarduy and Borges and their relation to a fictionalized Orient, Kushigian's study does not serve as a useful model for understanding Mexican orientalism. What would prove 
extremely useful for understanding this phenomenon is Said's method of relating works of art and literature to the larger historical context in which they were created, especially his insistence on how representations of the Orient are always shaped by the extra-literary circumstances of the author's life, including the political climate, cultural debates, and economic interests that shaped his or her life. (63)

While it does seem that the application of Kishigian's model of Hispanic Orientalism based on the analysis of Borges's works is limited, it is not altogether "useless" as Gallo argues. It is true that Hispanic Orientalism in the twentieth century is characterized by polyphony. However, what is not established precisely is the nature of the dialogue between the East and the West. Despite the curiosity and apparent reverence toward the Orient in Borges's works, one cannot but see between the lines the hierarchical structure of his relationship with the Other.

Such relationship is conditioned by several factors. On one hand, Borges could not avoid the temptation, as indicated earlier, to use the Orient as a canvas to draw this own image and that of Latin America. In doing so, he resorted to the tradition of Hispanic Orientalism existing in the works of his predecessors. Kushigian's descriptions of Borges's Orientalist tactics inadvertently conform to this supposition. Not only does she mention the traditional Orientalist motives in his narrative, she also points out his generalization of the West and the East, which is an unavoidable consequence of the reinterpretation of the Other (Orientalism 24). Kushigian refers to Foucault's notion of utopia that "affords consolation because they unfold in a fantastic, untroubled region" 
(Orientalism 21). It is created by means of fantasy; it is a fascinating mystery that irresistibly attracts Borges (Orientalism 23, 39). Nonetheless, this fatal attraction does not automatically make both parts of the dialogue equal. It reveals the fascination with chinoiserie, and thus the reinterpretation of the Orient from an outsider perspective. At the same time utopia, and this is important for our Orientalist quest, reveals the dissatisfaction of the author with the present; it sharpens his desire to retreat to the past, to the original stage, often idealized, where the pure essence of self is not yet contaminated by the hegemonic discourse of powers (Camayd-Freixas, Realismo 20). This symbolic return to the origins of Latin Americanism for Borges would mean the revision of the Colonial enterprise and its Orientalist imprint.

On the other hand, Borges uses this Orientalised image of the Other for selfdetermination and differentiation, just as Kushigian argues: "In the Orient Borges has located a culture that is radically different from our own, and he describes it in the sharper language of fantasy ... therefore, while the other culture is distinctive, it does identify itself as we do. In other words, its categories are our own, it is as we want it to be" (Orientalism 23). However, it is not this veneration that becomes the motor of Borges's Orientalization but instead the desire to define itself against the Other, much like it was done centuries ago in post-Reconquest Spain. That is why the fantasy, the reinvention of the Other, is crucial for Borges's representation of the Orient. This echoes Gallo's interpretation of Saidian Orientalism, when he states that Said "investigates 'the Orient' much as a psychoanalyst would interpret a fantasy: his emphasis is not so much on factual accuracy, but on the desires and fears that are projected into its construction. Analyzing 'the Orient' as a fantasy ... will allow us to interpret the cultural fantasies and 
fears about alterity" (Gallo 63). It will also allow Borges to define himself against this alterity.

A closer analysis of some of Borges's short stories and poetry allows us to see the continuity of Orientalist tradition in Latin America. It is notorious not only in his expressly Orientalist narratives, such as "El Aleph" (“The Aleph”), "El Zahir" ("The Zahir"), "Los traductores de las 1001 noches" (“The Translators of The 1001 Nights"), "La busca de Averroes" ("Averroës's Search"), "Funes el memorioso" ("Funes the Memorious" or "Funes, His Memory"136), "El jardín de los senderos que se bifurcan" (“The Garden for Forking Paths"), "El acercamiento a Almotasím” (“The Approach to Al-Mu'tasim"), and others, but also in his texts depicting Latin American reality. Borges continues the long-existing tradition of self-definition through the Other. Like his predecessors during the transitional period, he opts to Orientalize the self in order to be able to revise the traditional, canonized representation of Latin America, imposed by the metropolis.

In the twentieth century, having overcome the fear of a return to colonial times, Latin American authors engage in a more dynamic dialogue with the East, using it to define the self through the process of Orientalist differentiation. Marina Kaplan in her analysis of "El Evangelio según Marcos" ("The Gospel According to Mark," 1970) by Jorge Luis Borges places the author within the group of Orientalist post-Independence authors, from Domingo Faustino Sarmiento to Julio Cortázar and Juan Rulfo: "The central conflict occurs between two orders of the real, which traditionally, had been the divine and the demonic, white and black magic, or the civilized castle and its opposite: the enchanted forest (the site of adventure par excellence)" (317). The latter is nothing 
else but the Latin American pampas, a quintessential space of Otherness, a time capsule where the Orientalized protagonist exists till he confronts his civilized adversary. The similarity of the negative character of the old gauchos, according to Kaplan, is also symbolic, as "these gauchos now represent the intellectual barbarism, which for Borges consists in mistaking the text for reality. In this sense, the whole story is a mockery of literal readings and, therefore, a criticism of romances" (Marina Kaplan 327).

Thus, for Borges, the process of Orientalization of the Other is not done solely for the purpose of addressing the foreign or the national subject. Through the process of selfOrientalization and the Orientalization of the traditional Orient, he propagates his ability to engage in Orientalist discourse. This attests to his belonging to the dominant, not dominated culture, as the latter's versión de los vencidos ("version of the vanquished") is never strong enough to create and perpetuate an Orientalized image. This is an important underlying message of Borges's Orientalism that defines the so-called dialogue with the East: rather than a dialogue between two equally important and mutually respecting entities, it is a dramatization by Borges, carried out for the purpose of self-assurance of a Latin America that seeks to exchange the subaltern discourse with the hegemonic.

For instance, in his short story "Yo, judío" ("I, a Jew," 1934) Borges plays with the notion of the Other and the self. He questions his and, ultimately, his readers' desire to comprehend the present through questioning one’s own past: “¿Quién no jugó a los antepasados alguna vez ... Yo lo hago muchas veces, y muchas no me disgustó pensarme judío" ("Who has not, at one time or another, played with thoughts of his ancestors ... I have done so many times, and many times it has not displeased me to think of myself as a Jew"; Borges, Ficcionario 87; Borges, Selected 110). The image of a 
Jew results attractive to the narrator because of its historical exclusivity that acquired for him a romantic aura, especially in the nineteenth century. However, it is this romanticized, in other words, Orientalized, image of the Jewish Other that results attractive to the author who, unfortunately for his Oriental fantasia, comes to a mundane conclusion that his ancestry was "casi irreparablemente español" ("irreparably Spanish"; Borges, Ficcionario 87; Borges, Selected 110).

He ridicules the anxiety of belonging to the once marginalized Other in order to differentiate oneself, as he states: "Nuestros inquisidores buscan hebreos, nunca fenicios, garmantas, escitas, babilonios, persas, egipcios, hunos, vándalos, ostrogodos, etiopes, dardanios, paflagonios, sármatas, medos, otomanos, bereberes, britanos, libios, cíclopes y lapitas" $<$ sic $>$ ("Our inquisitors seek out Hebrews, but never Phoenicians, Garamantes, Scythians, Babylonians, Persians, Egyptians, Huns, Vandals, Ostrogoths, Ethiopians, Illyrians, Paphlagonians, Sarmatians, Medes, Ottomans, Berbers, Britons, Libyans, Cyclopes, or Lapiths"; Borges, Ficcionario 88; Borges, Selected 111). He accepts the charm of such quests; however, his protest is not against Orientalization, but against its Eurocentric version imposed on Latin America. It is significant, that the enumeration that starts with historical nations ends up with mythical creatures. It accentuates the idea of the universality of the concept of the Other. Borges uses this metaphor to question our reinterpretation of the Other and our desire to be identified as such in order to be different and pertain to this mythical attractive structure that the dominant culture has created in the first place.

In another short story, "Historia del tango" ("A History of the Tango," or "History of the Tango, $\left.{ }^{, 137} 1955\right)$, Borges himself indulges in the process of Orientalization. The 
origins of the tango are the perfect grounds for this process. Originated as "orgiástica diablura," the tango is viewed through the lens of its "capacidad sexual y capacidad belicosa" ("devilish orgy"; "sexual potency and combative potential"; Borges, Ficcionario 329-30; Borges, Selected 396). As such, Borges offers a page-long excursion into the question of virility with examples from Historia de los godos, Iliad, Beowulf, using almost as a epigraph to his review the words of an Afghani protagonist in Rudyard Kipling's Kim: “A los quince años, yo había matado a un hombre y procreado a un hombre" ('When I was fifteen, I had killed a man and begotten a man')" (Borges, Ficcionario 330). These references place tango in the Orientalized past, thus Orientalizing its present, and consequently, Argentina.

This image then is opposed to that of the gaucho that Borges sees as a symbol of national identity, unlike the soldier that he references above. However, his perception of the gaucho seems to arise from a Facundo-like narrative, where his image is Orientalized. Thus, Borges sees him as bearer of "tradiciones orales" who "no está al servicio de una causa y es puro;" his "valor cifrado" (reminiscent of maravillas of the first chronicles of the conquest) is enigmatic and attractive ("oral traditions"; "not in the service of a cause"; "courage ascribed to the former"; Borges, Ficcionario 331; Borges, Selected 398). It is not occasional then, that this authentic self is presented as the opposite to the tango, rooted in European Orientalism. Borges advocates for the revision of the traditional perception of Latin America, and its role in historical processes.

As such, he rejects the Orientalist image imposed by the metropolis and calls for differentiation. Borges almost echoes the comparison between Japan and Latin America by Gómez Carrillo in El Japón heroico y galante when he opposes the Orientalized self 
to the others: "El gaucho y el compadre son imaginados como rebeldes; el argentino, a diferencia de los americanos del Norte y de casi todos los europeos, no se identifica con el Estado" ("The gaucho and the hoodlum are seen as rebels; Argentines, unlike North Americans and most Europeans, do not identify with the state"; Borges, Ficcionario 33132; Borges, Selected 398). ${ }^{138}$ Thus, the Latin American self undergoes a process of Orientalization in order to throw off the shackles of European hegemony.

The perception of the proper Orient in the narratives of Borges does not avoid this anti-colonialism. For instance, in his poem "El otro tigre" ("The Other Tiger," 1960) the author evokes an exotic image of the animal that becomes an iconic symbol of the East. As such, his tiger is mysterious and ephemeral; Borges deciphers his shadow surrounded by the Oriental entourage in the labyrinth "entre las rayas de bambú" ("Among the slivers of bamboo"; Borges, Ficcionario 354; Rodríguez Monegal, and Reid 281). It is significant that the tiger, a perfect metaphor of the Orient, exists in a vacuum, as "En su mundo no hay nombres ni pasado / Ni porvenir, sólo un instante cierto" ("in its world, there are no names, nor past, nor future - / only the sureness of the passing moment"; Borges, Ficcionario 354; Rodríguez Monegal, and Reid 281). This anticipates and addresses the future criticism of the artificial imaginative nature of his images.

Borges is not alone in this enterprise. Other authors, like Alejo Carpentier, also resort to the Orientalist myth to find the answer to the question of Latin Americanism, as it interweaves the universal and the local, the individual (Camayd-Freixas, Etnografia 94). For instance, in his novel El arpa y la sombra (The Harp and the Shadow, 1979), Carpentier retakes the story of Columbus and his voyages, which in itself became a myth, Orientalized by the hegemonic power and perpetuated in subsequent literature. It is 
significant that Carpentier looks into the past in order to define the present and the future of Latin America (similarly, Elena Garro and Laura Esquivel and other female writers use this mechanism to carry out their iconic revision of La Malinche). He aims to revalorize the Colonial period for the purpose of differentiation from the imposed dominant discourse. In order to do so, Carpentier places his protagonist in a relative historical vacuum in order to preclude the traditional perceptions that could influence his revision: Columbus himself meticulously reconstructs the discovery, thus changing the Orientalizing discourse from the inside. It is also important, as Molly Metherd points out, that the narration is "isolated" in time, as Columbus reviews his Diary at the end of his life (232). This allows him, as in case of the chronicles narrated long after the events, to gain a certain perspective that legitimizes the revision.

Similarly, one can assume that Borges's image of the East is also isolated, and therefore Orientalized. Timothy Weiss points out a significant difference between him and other contemporary authors, which lies in Borges's acceptance that his idea of the Orient "derives from text books and books; it constitutes an imaginative space, a feeling, a collection of philosophical ideas," rather than real life experience; his only brief travel to Asia sparked his "library" interest in the Orient (20). So, unlike his predecessors, his Orientalization is conscientious, and the author openly admits it: for him, the mysterious shadow loses its enigma because "ya el hecho de nombrarlo / Y de conjeturar su circunstancia / Lo hace ficción del arte y no criatura / Viviente" ("but still, the act of naming it, of guessing / what is its nature and its circumstances / creates a fiction, not a living creature"; Borges, Ficcionario 355; Rodríguez Monegal, and Reid 282). 
Furthermore, Borges opposes this Oriental tiger "verdadero, el de caliente sangre" to the other tiger, "un tigre de los símbolos y sombras," the Latin American literary tiger of Borges ("the real one, whose blood runs hot"; "a tiger made of symbols and of shadows"; Borges, Ficcionario 354-55; Rodríguez Monegal, and Reid 282). Though opposed, at first glance, these two are intricately related. While between them "se interponen los convexos / mares y los desiertos del planeta," it is "en vano," as Borges "desde esta casa de un remoto puerto / de América del Sur, te sigo y sueño" ("the convex oceans and the desearts / spead themselves across the earth between us"; "in vain"; "from this one house in a remote lost seaport / in South America, I dream you, follow you"; Borges, Ficcionario 354; Rodríguez Monegal, and Reid 281). Furthermore, the point of departure of the two tigers is similar: it is the "penumbra" of the "Biblioteca laboriosa;" therefore, it is of no surprise that both share the same virtual geography, "su selva," where both "salvará[n] las bárbaras distancias" ("half-light"; "painstaking library"; "its jungle"; "it will cross the wilderness of distance"; Borges, Ficcionario 354; Rodríguez Monegal, and Reid 281). The word bárbaras here is key for establishing the link between the Oriental and the Latin American tigers from the point of view of the Orientalist dialogue of civilization and barbarism, ongoing from the early post-Independence period.

The parallelism established by Borges between the Orient and Latin America is possible only through the Orientalization of the former, its reinterpretation from the point of view of modern circumstances, and the self-Orientalization of the latter. The Orient for Borges is oxymoronic: he admits that the Oriental tiger is the product of his imagination. At the same time, the ephemeral Latin American tiger surpasses its counterpart by fictionalizing it through their contact. This can be seen as an allusion to the Latin 
American past and present Orientalized by the Colonial power. In this light, it is of no surprise then that Borges seeks to find the third, "el otro tigre" (the real Latin America?) that exists "más allá de mitologías;" however, he feels he cannot embark on this journey, "esta aventura indefinida, / Insensata y antigua" ("the other tiger"; "out of reach of all mythology"; "this ancient and vague adventure, / unreasonable"; Borges, Ficcionario 355; Rodríguez Monegal, and Reid 282). It seems that for Borges the enterprise of deOrientalizing the past appears almost impossible; however, he keeps on looking. He does not lose hope of rescuing the third tiger, the real Latin America, different from the one almost everyone believes in at the moment. This is his "trans-modern response to the European modernity" where the truth emerges from the borderland and not from the metropolis (Barragán-Ekhause 294). Thus, is truth of the subaltern offers a new selfOrientalized version of Latin America that is set off against both Europe and its own Orientalized image imposed by the latter.

The notion of memory and history is crucial in Borges's Orientalism. It allows him to establish the relationship between the Latin American past and present, and by reviewing the latter, the former would be consequently de-Orientalized. Curiously, in criticism, the analysis of these two phenomena in Borges was not only made from a literary point of view. Neuroscientists like Rodrigo Quian Quiroga (University of Leicester, UK), analyzed Borges's short stories like "Funes the Memorious" and "The Garden of Forking Paths" as related to the functions of memory and fourth dimension, coming to the conclusion that they might have predicted the hypertext and the Internet (Kodama vii-viii). Though, he is cautious and warns against over interpretations and suggestions that Borges "foresaw modern neuroscience," Quian Quiroga, however, finds 
that Borges's narrative "had the perfect words to express the results of my research [in neuroscience] and ... with astonishing clarity ended up sorting the pieces of the puzzle I had been working on" (8). Therefore, he finds a palpable, real representation of the literary interconnectedness of Borges's world.

This interconnectedness, on the metaphorical level, is what allows Borges to travel through space and time in his Orientalist journey. Shlomy Mualem in his research on the influence of the ideas of Plato on Borges notes that in Western history, the intellectual dramas of the former and the philosophical fiction of the latter are among the most sophisticated examples of the synthesis of mythos and logos, idea and fantasy, whose juxtaposition is meant to demonstrate, first and foremost, the connectivity between classical and contemporary history, thought and narrative (13). The above mentioned approaches, like the two tigers of Borges, one - on the imaginative level, the level of mythos, and the other - scientific, on the level of logos, attest to Borges's global understanding of the world, and Latin American history in particular. The revision of the past and present of the latter in his narrative paves the road for the process of differentiation of Latin America through its special and temporal interconnectedness and connection to the imaginary or real Orient.

From a psychological point of view, these interwoven concepts, real and unreal, memory and oblivion, essence and vacuum, are critical for the ontological development of a human being, when the time is "marked, lost, and recovered in the critical junctures of presence-absence of the first, indispensable object" (Woscoboinik 223). For a human it is usually the mother figure who plays this essential role; for the onflow of Borges's cyclic history and time, it is the presence-absence of the de-Orientalized self, and 
subsequently, Latin America that defines these critical junctions where the development takes place. This echoes the suggestion of Ana Tissera, who in her analysis of the structural complexity of Borgean worlds proposes that he constructs their image "en torno al sí o no del sujeto que los evoca," so all the manifestation of his time are mere reiterations of propositional attitude related to the self ("around the yes or no of the subject who emulates them"; 203). Like the law of communicating vessels, Borges is looking for a delicate equilibrium between the West and the East; it is only then when the Latin American vessel overflown with Colonial Orientalism can recede to historic reality. The cyclical notion of time allows for this communication between different entities, and it is underlined over and over by Borges in his narrative. ${ }^{139}$

In conclusion, the narrative of Jorge Luis Borges showcases a more dramatic turn towards Americanism than at the beginning of the twentieth century. While his predecessors, like Gómez Carrillo, use the dialogue with the West to legitimize Latin American autonomy, Borges is able to manipulate the conversation between East and West, de-Orientalizing the image of the former Colony. At the same time, he uses preconstructed and self-Orientalized images, such as that of the gaucho, to oppose mainstream European Orientalization. This allows him to intensify the process of differentiating Latin America from the Old World through his narrative, which seeks to exchange subaltern and hegemonic discourses. 


\section{§ 4. Differentiation through Self-Orientalization: Revalorization of the Traditional Colonial Other}

It becomes clear from the analysis in the previous sections that there was a gradual tendency in the twentieth century to address the issues of Latin Americanism from a new perspective. Orientalization played a crucial role in this process; so did the Oriental Other that played the role of the counter weight in the process of selfOrientalization (or de-Orientalization, if seem from the standpoint of the European hegemonic power). However, towards the second part of the century, it became more and more common to look at the Latin American past in order to get to the "source" of the problem. It also allowed looking at history from a greater distance, which could contribute to a better analysis of the negative and positive consequences of colonialism in Latin America, such we have seen in the works of Borges and Carpentier.

The analysis of both official history and official historical discourse became primordial to the "nationalization" of the Latin American image. Magali Carrera points out that this process started already during the independence movement, when "the body of the Indian became the critical nexus in the discourse of origin and authenticity" (147). However, it was not until the twentieth century that Latin American authors embarked on a full-scale campaign to rescue the image of the Amerindian and the mestizo. The nineteenth century was able to provide only a "simulacrum of the Indian [with] the aura of an elite culture from which the present of the nineteenth century could claim a legitimizing descent." This had a strong connection with the profound Orientalization by hegemonic society as seen in the eighteenth-century castas paintings and the neoclassic 
tendency to represent the Indian as the conquered object subjected to colonization and Westernization (Widdifield 10-11). Especially during the second part of the twentieth century, the efforts to rescue and revalorize the colonial subject coincided with the growing political and cultural awareness of this long-ignored entity.

To the extent that a glance at the colonial past may address the issue of the Orientalization of the Amerindian by the dominant power, perhaps one of the most powerful of such revisions is that of the figure of La Malinche (Malintzin), the Orientalized figure par excellence of Mexican Colonial history. Her image was constantly present in the chronicles of the discovery and the conquest in the narration about the Mexican campaign of Cortés. However, as indicated in Chapter 2, different authors ascribed to La Malinche varying roles in those historical events. As such, Gómara's chronicle only occasionally mentions her name and does not attribute to her any protagonism. At the same time, Bernal Díaz del Castillo draws an exceptionally positive image of La Malinche, naturally, from the point of view of the conquistadors. These and the other renderings of the historical Malinche in the writing of the period were heavily influenced by the agenda of their authors and the interests of the Spanish Crown, thus presenting reader with an Orientalized rather than historically accurate Malintzin.

This Orientalized Malinche became an iconic image and a negative symbol of the Westernization of the Americas and is copiously reflected as such in Mexican arts. Daniel Meyrán suggests that her depictions displayed a surprising equanimity and persistence in rendering her image based on "el romanticismo ahistórico y el patriotismo con un tema común: el tratamiento peyorativo de Malintzin/Marina/Malinche" ("historical romanticism and patriotism with a common theme: the pejorative treatment of 
Malintzin/Marina/Malinche"; 167). One of the reasons for this tendency, as Lucía Guerra Cunningham argues, is the patriarchal tradition dominant in the arts before the twentieth century. Literature was no exception: it was a territory dominated by masculine imagination where patriarchal hegemony deeply impacted not only the art of writing but also the approach to certain literary topics (Guerra Cunningham 21). In this type of writing, the female subject speaking and acting for herself was unheard of, or better said, ignored (Jardine 25). The Independence of the Colonies, however, called for the reconsideration of the Orientalized Latin American past, and the image of $\mathrm{La}$ Malinche was no exception.

The revision of La Malinche happened gradually, and for long, many of the authors, including those who criticized the official nationalist discourse, were not able to make significant changes, thus, mostly recreating and, therefore, perpetuating the existing paradigm in their own style (González Hernández 164). This revision did not come only from women writers (although Elena Garro, Laura Esquivel, Lucha Corpi and others were the ones who completed the de-Orientalization project by seeking to give a voice to the silenced subjects). Before these successful revisions, there were several attempts, both from female and male authors, to rescue this historical character that became a symbol of surrender to the colonizer and a curse word in contemporary Mexico. One of them, for instance, is Sergio Magaña (1924-1990) with his historic drama Cortés y La Malinche (Los Argonautas) (1985) or Moctezuma II (1954). Sandra Messinger Cypess notes that by establishing parallels between the myth of Jason and Medea, Magaña shifts the blame from Malinche to both her and Cortés (Myth 46-47). Although, despite giving Malinche certain protagonism in history, this and similar 
revisions failed to free her image of the pre-established Orientalized canon in which she was placed by hegemonic society.

One of the first successful attempts to give a voice to La Malinche is Elena Garro's (1920-1998) short story "La culpa es de los tlaxcaltecas" ("Blame the Tlaxcaltecs") in Semana de colores (The Week of Colors, 1964). Her success can be attributed not only to her new de-Orientalizing approach, but also to the changed circumstances of the social situation of women writers in this period. During the second part of the twentieth century, women writers and subjects emerged with a new strength to oppose the patriarchal tradition that had dominated literature. At the heart of this process was the movement of l'ecriture feminine under the lead of Simone de Beauvoir, Julia Kristeva, Luce Irigaray, Hélène Cixous, and others who argued for a creation of an exclusively female text as a result of their gender differences, which would express themselves through their bodies, thus opposing the existing masculine literary tradition (Zepp 6). It is this recognition of the female subject and its protagonism in literature and history that allowed Garro to embark on her revisionist journey.

Past and present are intricately related for Elena Garro. This cyclical notion of history, as it was seen previously in Borges, allows the author to revise the past through the present, as well as speculate about the repetition of history in the future. It is not by accident that the binary rhythm that is typical in Borges can also be observed in Garro's works (Cruz García 64-65). The dichotomies formed by historical duplicity are what creates cyclical time and force upon the characters an imminent connection with the past. In the case of women, and La Malinche in particular, as Sandra Messigner Cypess argues in her study of Garro's approach to the figure of Cortés's translator in Los 
recuerdos del porvenir (Recollections of Things to Come, 1963), "this implies that women must repeat the tragic past of La Malinche until the sociocultural conditions are themselves changed to allow for a new pattern of behavior to develop" (Garro 120). This original tragic pattern results from the Orientalization of the Colonial Other by hegemonic society. Thus, the only way to break with this tradition is to rescue, revalorize this past, and de-Colonize it, so that Latin American woman and Latin America itself could escape the vicious circle of Orientalized history.

Patricia Gonzalez in her study of Garro's female subjects argues that the archetypical feminine image that Garro recreates in her works is bound to overcome her isolation through fantasy, imagination, madness, or eternal death (78). Laura-Malinche, the protagonist of "La culpa" shares this fate, as she and her Indian husband from the past are longing for the end of time, when present, past and future fuse and become one. Since the Orientalization of La Malinche is deeply rooted in the historiography of the early colonial period, Garro launches her review of the traditional myth of La Malinche by looking at the past through the lens of the present. As such, in the story "La culpa," two parallel worlds coexist in the narration, modern Mexico with its cultural and political issues and Tenochtitlan, the Aztec capital, at the time of the conquest. It is not an accident that the point of contact for both seems to be the chronicle of Bernal Díaz del Castillo, read by the main character. One of the main sources of the Orientalization of Colonial Mexico, Bernal's chronicle functions as an Oriental folding screen or mirror, framing the actions of the characters in the past and present. Thus, both worlds are mutually penetrable and intertwine in the mind and life of Laura, the protagonist, as Garro carries out her historical revision through her eyes. 
Garro was not alone in this effort. Several writers and filmmakers before and after undertook such historical emendations in their quest for revalorizing the historical past, Orientalized by the mainstream social groups. For instance, one later revision is the film by Brazilian filmmaker Nelson Pereira dos Santos, who in 1971 released his rendering of one of the sixteenth-century chronicles (1557), "Como era gostoso o meu francês" ("How Tasty Was My Little Frenchman"). As does Elena Garro, he superimposes the traditional narration and his contemporary society, creating a sharp critique of the latter. As Silvia Nagy-Zekmi suggests, they both take advantage of Orientalism "to create a domestic Latin American discourse and, in some cases, a discourse of resistance against the dictatorial powers" (18; my translation). This discourse is, in a sense, anti-Orientalist, as it protests the hegemonic approach to the subject of the Latin American Other. However, it embarks on its own campaign of self-Orientalization in order to rewrite the Colonial past.

Pereira dos Santos exposes the cultural and mental gap between the Europeans and the aboriginal society where the captive Frenchman is forced to live, a factor that defined the development of Hispanic Orientalism in its transatlantic journey. As did Sarmiento earlier, he puts in perspective and questions the traditional perceptions of civilization and barbarism: the atrocity of the ritual anthropophagy as opposed to the greed-driven Europeans, one of whom, the captain, betrays the Frenchman to ensure his upper hand in the future negotiations with the Tupinambás, and the Frenchman himself, who kills the captain and plunders the grave of the deceased husband of his indigenous wife looking for loot (Young 86). This revalorization of the Orientalized self allows 
Pereira dos Santos to question not only the canonized image of the aboriginals, but also his contemporary hegemonic powers and their actions.

The anthropophagy here, as in the historical visions in "La culpa," serves as an avenue to transport the contemporary reader to the past and transform the (his) popular memory in order to "redigest" the Orientalist image of the Amerindian self and history. Pereira dos Santos carries this out on a metaphoric and literal level, as the protagonist of his film is ultimately devoured by the Indians. This echoes the Manifesto Antropófago by Oswald de Andrade (1928), which as Cristina Rocha notes, tried to offer a modernista "response to the perceived problem of Brazilian cultural dependency by celebrating creolization's ability for absorbing or 'cannibalizing' European metropolitan culture and thus giving it a local flavor" (202). Similarly, memory for Elena Garro allows for a similar process for her contemporary Mexican society.

In the same way, Elena Garro achieves this through the dialogues between Laura, the protagonist, on the one hand, who oscillated between the mirrored worlds of the past and the present, and personifies La Malinche, and, on the other hand, Nacha, her mysterious maid who, as her señora, also belongs to both worlds. Garro plays with stereotypes of the past and the present in order to revalorize the Mexican past. "La culpa" superimposes both images of the world, and it is in the difference between them that she finds the hegemonic Orientalism imposed by Colonial society. For instance, Laura admits that her husband Pablo looks very much like her "primo marido" ("cousin husband"; Garro 19). The difference, however, lies in their personalities. Pablo is wrathful and violent, while her Indian husband is often idealized and portrayed as kind and forgiving (he does not kill Laura for her betrayal). It might be significant, in light of the biblical 
references in the traditional chronicles that the name of the "marido nuevo" serves as a reference to the figure of St. Paul, whose convertion was followed by his vehement dedication to spreading Christianity around the world with his symbolic sword, that is, the Bible ("new husband"; Garro 17). Thus, he is expected to share the hegemonic vision of the conquistadors who also brought la espada y la cruz ("the sword and the cross") to the New World.

Indeed, the portrayal of Laura's Indian husband, made up of references by the other characters, approximates the style of the chronicles, both semantically and lexically. The difference lies in the distribution of these characteristics. Laura, for instance, points out the Indian's nudity and closeness to nature. His physical wound, constantly oozing blood, can be perceived as a symbolic Latin American trauma: its Orientalization led to the permanent and recurring damage to its image that leaks throughout the pages of historical documents and literature. On the other hand, the references to the Indian by Pablo Aldama and his world are, as expected, traditionally Orientalized: he is dark, both physically and metaphorically; he is "asqueroso," "sádico," and "brujo" ("disgusting"; "sadistic"; "witch-like"; Garro 22-23). Pablo also tends to generalize and extend his characterization of Indians as regards their ethnicity rather than their individuality, when he refers to Laura's husband from the past as "estos indios salvajes" ("these savage Indians"; Garro 16). These opposing or dialoguing perspectives allow Garro to create a depth in the image of the Other that was lacking as a result of the Orientalization by the hegemonic power.

This second dimension serves as a backdrop for the revalorization of the main character, Laura-La Malinche. A symbol of the colonial chingada, this image, if rescued 
and given a proper voice, could facilitate the revisionist campaign of Latin Americans in their search for differentiation from the West. The traditional dichotomy of the representation of women in literature allowed for two categories: first, what is known as marianismo followed the example of the Virgin Mary; the other was that of a lost woman. Silence is the key characteristic of both of these representations (Araújo 120). By extension, both were represented as an object rather than a subject. In traditional literature the symbolic and physical surrender of La Malinche as the new Eve of colonial patriarchal society becomes in the eyes of machista society the quintessential cause of the loss of the Aztec Empire (Guerra Cunningham 21). By extension, "she may be also considered the first mother of the Mexican nation ... symbol of national betrayal" (Messinger Cypess, La Malinche 2). Such visions were copiously reflected in literature even in the twentieth century. For instance, in El laberinto de la soledad (1950) by Octavio Paz, his campaign to cast new light on the Orientalized Latin America led to the recycling of the traditional patriarchal approach, manifested in assertions like: "Es verdad que ella se da voluntariamente al conquistador" ("It is true that she gives herself up voluntarily to the conquerors"; Paz, Laberinto 77). Thus, the female subject here remains objectified, as the perspective of El laberinto de la soledad continues to be hegemonic and phallocratic.

Such patriarchalism is what Garro's Malinche has to overcome along with the hegemonic Orientalization of the colonial subject. Sandra Messinger Cypess in her comparative study of the literary and personal opposition between Elena Garro and Octavio Paz, symbolically entitled Uncivil wars, points out that precisely this differential approach to the question of gender is what defined their historical 
perspective of Latin American subjects: a passive object of sexual desire versus an active subject who creates his/her own history (Wars 17). Garro herself set an example for such reading: Rhina Toruño recalls the episode of Garro's life when she asked to be placed in a female juvenile facility as a delinquent in order to narrate the story of the young women in detention and to denounce the cruelties of their captors (36-39). Garro's campaign to revalorize La Malinche and the female subject more broadly has a double meaning: as she becomes a symbol of the colony itself. Latin America can be perceived as a female subject, chingada by the colonizer and neglected by the colonized who did not take pride in her. Only a de-Orientalizing discourse that breaks with the patriarchal hegemonic view of the female subject could lead to a successful historical redemption for Latin America.

Therefore, Garro protest such hegemonic representation by carrying out her narration of the world of La Malinche through her own perspective. It is she, along with Nacha, who narrate and advance the actions in the story. Throughout the narrative the modern Laura is gradually transformed into La Malinche, symbolically reversing the process of Orientalization. At the beginning of the story, the Indian husband notes that she is too pale, to the point that her hand "está muy desteñida, parece una mano de ellos" ("is very pale; it looks like their hands"; Garro 14). Under "ellos" he understands the conquistadors; however, he never refers to them as such, nor does the name La Malinche appear in the story. Laura also perceives this whiteness; she is almost blinded by it. This whiteness is what ignites the process of change, as "el tiempo había dado la vuelta completa" ("time had come full circle"; Garro 12). It is opposed to the darkness 
of the Indian, to the night when the narration takes place, and to the "cafecito" ("coffee") served by Nacha throughout the story.

The more Laura interacts with her other husband, the more Indianized she becomes. At some point, when a doctor is called to assess her, she is so lost between her past and her present, that she is not sure which story she had to tell. When Pablo, a senior official in the Mexican Government, perceives her "betrayal," he calls Laura "tan baja" ("so low"; Garro 23). This echoes the Orientalized perception of the Amerindians in general, as low, savage, and incomparable with the colonizer. By comparing both worlds, Garro achieves --to paraphrase the words of Charles Perrone-- the juxtaposition of the "old (primitive, native, savage, under-developed) and the new (modern, industrialized, developed)" that allows her "to ridicule social values and criticize the statute of ... [the Mexican] subject" (72). It discloses the Orientalization path of the Amerindian Other, that is, Orientalization by association with it. However, unlike the traditional Malinche, Garro's character becomes an active subject. It is not the men who decide her fate, but herself (Messinger Cypess, Garro 131). This is crucial, as it reflects the revalorization path of Garro's Orientalism, which gives a voice to the previously silent subject.

However, what is more important for Garro's revisions is the internalized sense of "culpa" ("fault") of her Malinche. While she repeatedly says, that "la culpa es de los tlaxcaltecas," her story-long dialogue with Nacha seems to be carried out in an attempt to persuade herself that it is true ("the Tlaxcaltecs are to blame"; Garro 11). Similarly, the image of La Malinche in Latin American literature always appeared Orientalized, despite the claims of the authors to address it from a new refreshing point of view, as it was seen 
in the works of Sergio Magaña or Octavio Paz. To add to this binary opposition, Garro plays with the notion of "la noche triste" ("the night of sorrows," the traditional reference to the forced retreat of the Spaniards during the conquest of Mexico). This is done, again, on several levels. First, the word "triste" (lit. "sad") is constantly repeated in the story, concentrated mostly at the beginning when Laura is still undergoing her transformation. Secondly, it is mostly during the night (or in little light) when the Indian and Laura can see each other. She leaves Pablo forever also during the night. This can be seen as a symbolic revenge: the Indians recover what is "theirs" causing the defeat of the colonizer (literally, Pablo's illness).

Thus, Elena Garro is reconstructing the process of Orientalization of the Other. The association with the Amerindian is what causes Laura to become La Malinche, both in her own eyes --as she sees the chaos of the defeat of Tenochtitlan and the corpses in the canals that now became the modern-day Periférico or beltway of Mexico City-- and in the eyes of her husband, who Orientalizes her and ascribes to her the traditional characteristics of the Other found in the chronicles of the conquest. This societal post mortem of Orientalization allows Garro to reveal its causes and objectify them. Only such conscious revision can fully address the question of the revalorization of the past and lead to differentiation. Nevertheless, Orientalization occurs even during this process, albeit from a different standpoint and for a different purpose. The somewhat idealized image of the Other points out to self-Orientalization, without which, as seen in the works of other twentieth-century authors, the process of differentiation would not be complete.

Elena Garro's Orientalism, therefore, relies on a historical revision of the past for the purpose of its revalorization that will allow bringing to light the uniqueness of the 
historical path and role of Latin America, overlooked by traditional Orientalism. This allows the author not only to address the Orientalized image of the Colony, but probably, most importantly, to revise the patriarchal image of the female subject, Orientalized not only by the colonizer but also by the colonized masculinity. Such revision inspired a more open debate on the question, and produced even further attempts to redefine the female subject. For instance, Guadelupe Cortina notes that several Jewish-Mexican authors, like Margo Glantz, Ethel Krause, Sara Levi-Calderón, and Sara Sefchovich, embark on a similar journey looking to define the place of a Jewish-Mexican female subject in the history and culture of Mexico through the revision of its hybrid nature and its relationship with mestizaje (12-13). Garro's approach became very fruitful, especially for Hispanic authors residing outside of Latin America who addressed the problem of mestizaje and cultural memory in relation to temporal and geographical displacement, like Lucha Corpi in her novel Black Widow's Wardrobe, or Dreaming in Cuban by Cristina García.

The revalorization of the past, thus, became one of the most prominent characteristics of Hispanic Orientalism in the twentieth century. From Abel Posse's Perros del paraíso (1983) to Ana Lydia Vega's Falsas crónicas del Sur (1991) and Paloma Pedrero's La isla amarilla (1995), many contemporary authors followed this path in order to redefine the Latin American subject and differentiate it from the canonical, stereotypical Other, forced upon the continent by hegemonic colonial discourse (GosserEsquilín 202-03; Berardini 276). The desire to give a voice to the silenced Other, then, approaches the perspective of the self-Orientalizing writings of the mestizo and 
indigenous chroniclers, who also sought differentiation from the stereotypical image created by the "official" chronicles of the discovery, conquest, and colonization.

\section{§ 5. Conclusion}

The twentieth century brought new concerns to the Latin American continent. Its preoccupation with its own history and identity only intensified after the creation of the Latin American nations in the nineteenth century. Ivan Schulman argues that "a detailed revisionist study of Modernism's Oriental strategic formation . . . will confirm everpresent emancipatory projections and epistemological concerns linked to the reconstruction of the self, the nation, and the universe through the visioning of an alternative cultural space" (Schulman 105). These concerns became the catalyzer for the development of the new Orientalist mechanisms of the modern period, with its redefined frontiers and power shifts.

In the twentieth century the now independent Latin America could allow itself to indulge in traditional reinterpretive and reimaginative Orientalism directed to both the traditional and non-traditional Orient. Modernista authors, such as Gómez Carrillo, produced numerous texts marked by exoticism and admiration for the reconstructed image of the Other, in similar fashion to early Peninsular Orientalism. However, already during this period, a significant distinction is established between these approaches. While the original paradigm of Hispanic Orientalism is used by the authors for the purpose of appropriation of the Other, the modern paradigm is implemented to seek differentiation from the former hegemonic powers. 
Gómez Carrillo's Orientalist revisions of past and present, East and West, allow him to argue for the revalorization of Latin American history, but not for the purpose of domination of the Other, but rather to create a distinction from the traditional image of the subaltern. In this sense, Gómez Carrillo occupies a middle ground between the negativism of Saidian Orientalism and the positivism of Kushigian's. This approach allows the author to occupy the position of spectator (flanêur) rather than actor, distancing himself from the Other. He seems to appreciate the Orient for its Otherness, without appropriating it, contrary to what Hispanic Orientalism did during the Medieval and Renaissance periods when the Other was perceived as a threat to the existing hegemony.

These tendencies only intensify with time, and display sharpened revalorization mechanisms that do not rely as heavily on traditional Orientalism as does modernista literature. For instance, the present analysis of Hispanic Orientalism's processes of appropriation and differentiation reveals that the works of Jorge Luis Borges - so often criticized as "evasive" and "cosmopolitan" - actually become the stage for a more dramatic turn towards Americanism than at the beginning of the twentieth century. His Orientalization springs not as much from the unilateral manipulations of the Other, but rather from a dialogue with the West in order to legitimize Latin American autonomy. Consciously or not, what Borges does is to manipulate the conversation between East and West to de-Orientalize the image of the former Colony. In doing so, he uses preconstructed and self-Orientalized images created by his predecessors during the postIndependence period (like the gaucho), with which to oppose European mainstream Orientalism. As a result, he seeks Latin American differentiation from the West by 
inverting the subaltern and the hegemonic discourses. By being able to produce hegemonic discourse, he allows the Latin American Other to exonerate itself and establish itself as another of the world's powers.

The globalization processes and political changes of the late twentieth century only intensified this desire for differentiation. Many authors find an effective path in this direction, not so much by addressing the canonized Orient, but rather by looking at how history has been Orientalized by the hegemonic Colonial powers. One such author, Elena Garro, embarks on this historical revision in order to redeem one of the most emblematic symbols of colonial domination, La Malinche. She dismantles the traditional Orientalized image of this historical figure by presenting her, to use a mathematical expression, as a case of "proof by contradiction." Skillfully replicating the path of traditional Orientalism that converts Laura-Malinche into the Colonial Other, she reveals the artificiality of this approach and the need for its revision. Despite (or perhaps because of) the fact that the images of the past she creates are somewhat idealized, her thesis, the imminence of historical revalorization, becomes obvious to the reader. This revalorization then addresses the question of the differentiation of Latin America and its cultural and historical uniqueness.

In sum, modern Hispanic Orientalism displays an intensifying tendency to revise the Latin American past, as well as reconsider its interaction with East and West. This is affected by means of a number of techniques, from the juxtaposition of Latin America and the traditional Oriental Other, to the contraposition of the versions of the conquerors and the vanquished, the colonizers and the (formerly) colonized. The main goal of these manipulations, however, remains the same: to differentiate Latin America from the 
traditional hegemonic colonial discourse for the purpose of establishing a more autonomous national identity and defining a place for Latin America in a de-centered contemporary world.

\section{NOTES}

${ }^{125}$ The decolonization of Latin America reached its apogee in the first half of the nineteenth century. During that period, Spain was considerably weakened politically and economically as a consequence of Napoleonic invasion. The American colonies were not something of an immediate concern of Spain at that moment, and the rupture became imminent. The year 1810, especially after the meeting of Las Cortes de Cádiz in Spain, was the turning point in the history of the New World. Las Cortes de Cádiz convened on September $24^{\text {th }}, 1810$. Among other important decisions, Las Cortes voted on the first Constitution of Spain. In its 384 articles, the Constitution guaranteed freedom to print any material (except for religious texts), inviolability of domicile, legal egalitarianism, among others (Tuñón de Lara 398-99).

The criollos, taking advantage of the political instability in Spain, launched the campaign for independence that achieved almost immediate results. As such, already on May $25^{\text {th }}, 1810$, the Viceroy of the Viceroyalty of Río de la Plata had to resign and yield his position in Buenos Aires to the Junta led by Manuel Belgrano (1770-1820) (Tuñón de Lara 401-02). On September 16 ${ }^{\text {th }}, 1810$ the Viceroyalty of Nueva España launched its independence campaign with "grito de Dolores" ("Cry of Dolores"). The "grito de la independencia" or "grito de Dolores Hidalgo" is one of the iconic moments of the Mexican independence campaign. On the Sunday morning of September $16^{\text {th }}, 1810$, the local priest of the town of Dolores, Manuel Hidalgo, called his fellow citizens to fight for the independence of their country and the abolition of "mal gobierno" ("bad government") and the so-called "Gachupines." (The last term is a derogatory name for the Spanish noblemen, hidalgos, that is considered to originate from a last name of Spanish nobility from the South, the Cachopines).

The process of rupture between the colonizer and the colonies accelerated after Napoleon's defeat during the rule of Ferdinand VII (1813-1833). The two key figures of the independence movement of the period, José de San Martín and Simón Bolívar, between 1818 and 1823 bring independence to Chile, Nueva Granada, Venezuela, Colombia, Mexico and Peru contributing to the establishment of an independent country. This moment marks the rupture of the former Other with its "patron" and, hence, initiates a new era, when the nature of Hispanic Orientalism has to be revised due to the dramatic change in the circumstances. 
${ }^{126}$ Albert Memmi describes this paradox of Latin America in his latest book Decolonization and the Decolonized (2006). He compares the situation in post-colonial Latin America with post-colonial Northern Africa, finding striking parallels in the ways of functioning of the former colonies. However, the question remains if and how the colonizer prevented the colonized from developing his leadership strategies and decisionmaking that ultimately impedes the latter to successfully govern the newly formed society. See:

Why Mexico, also an oil-producing country and one of the leading beneficiaries of tourist dollars, has been subject to periodic crisis that have led it to the brink of bankruptcy and forced it to beg for debt relief from foreign debtors? In 2003 Argentina declared that it would unilaterally cancel three-quarters of its debt; between individuals this would be considered fraud and subject to prosecution.

Such is the paradox. Generally speaking, the third world is poor and dying of starvation. Potentially it has the wherewithal to supply the needs of all its citizens, but lacks organization and suffers from an ineffective, absurd, and scandal-ridden system of distribution. (Decolonization 7)

${ }^{127}$ Memmi argues that the attractiveness of the military regimes is rooted in the fact that "the military, which is far from being reclusive, has the advantage of being able to impress the crowds with their uniforms, their weapons, their medals, and their theatrical ceremonies. The list of soldiers who have held power in once colonized nations is extensive" (Decolonization 16). However, it is crucial to remember that it is not only the "exterior" that differentiates the military regimes from the other types of regimes. Unlike them, the military is by default, organized; strategizing is their way to survive and succeed in combat. Therefore, in a situation of instability and uncertainty, the military men are often the only ones who are able to make fast and effective decisions and the only ones who have organizational skills. Hence, political power often rests in their hand. And they maintain it in military-style way, insuring the "discipline" of their subjects by using repressive measures, and gradually becoming tyrants.

${ }^{128}$ The translation of the quote is the following:

When European civilization strengthened its power and selfconsciousness, it attributed this capacity to redeem themselves through imitation to a number of other nations, including, since the seventeenth century, the Muslims. But the Amerindian was a striking mirror, and the Europeans diverged increasing attention to it. During centuries, the men of Roman-Catholic tradition had distinguished themselves from Muslims and Jews by not wearing a beard. As they arrived to the New World, they noted, rightly or not, that they shared this quality with the Amerindians, 
whose sparse hairiness gradually became a basic characteristic of their descriptions. It is a fact that Europeans started wearing beards beginning with the nineteenth century, and somehow, even though surely the causality is not so direct, this change tells us that the Other par excellence, the one to distinguish oneself from, was not any more the Jew or the Muslim, but the Amerindian.

${ }^{129}$ The application of the Western term "post-colonial" to the neo-colonies, such as Guatemala, may be problematic because of its relative economic and political independence on the international arena.

130 Alexander Pushkin's great-grandfather, Abram Petrovich Gannibal was brought to Russia from Africa as a gift to Tsar Peter the Great who educated him and made him a nobleman. Pushkin will write a historic novel The Negro of Peter the Great (unfinished), which curiously in Russian original does not use the word "negro" but "Arab."

${ }^{131}$ It is of interest as well the relationship between "the Shadow of Islam," in terms of Hernán Taboada and "la bruma del extremo Septentrión" by Gómez Carrillo (Gómez Carrillo, Crítica 66).

${ }^{132}$ In order to establish the basis for his revalorization campaign, Gómez Carrillo needs to assure his readers of his impartiality. He is familiar with the criticism of the Eurocentric views of many of the travel logs by European and even non-European travellers. Therefore, in the introduction, he acknowledges and ridicules the preexistent stereotypes about Russia based on its perception as the other of Europe. But the battle between French and Russian influences on Pushkin is won by the exotic Other that allows the poet to embrace the mysterious inclinations of his soul dormant at the time. This approach, however, disregards the fact that Russian nobility of the nineteenth century was highly influenced by France to the point that many could not speak Russian well (for instance, some of the members of the Decembrist noble revolt against the tsar in 1825 had to be interrogated in French because they could not express themselves well enough in Russian). These prosaic facts, if used, would not have the same impact as the road that Gómez Carrillo takes, so they are omitted.

${ }^{133}$ Such omission by Gómez Carrillo is, however, strategic. In his travel log dedicated to Russia, he recalls this revolt and its consequences in the chapter "La obsesión de Siberia." 
134 The poem in question is "The Prophet." Inspired by biblical episode, it is perceived by Pushkin and later other poets as a metaphor for the messianic role of poetry as a weapon for sociopolitical struggle.

${ }^{135}$ Pushkin was shot, and did not die because of a stab wound, a more romantic variant of the duel suggested by Gómez Carrillo. An important detail is that his death resulted in the discovery of another Russian national poet who became a symbol of Romanticism in Russia, Mikhail Lermontov after he composed and read an ode dedicated to Pushkin's passing.

${ }^{136}$ See Borges, Fictions 131.

${ }^{137}$ See Borges, Fictions 260.

${ }^{138}$ It is crucial here to note that the notion of "American" for Borges here is more inclusive, than that of his predecessors. Unlike Gómez Carrillo who uses the terms latinoamericano and norteamericano, he implements americano when referring to all the inhabitants of the American.

${ }^{139}$ For the par excellence manifestation of this idea, see "El tiempo circular" ("Circular time"), where Marcus Aurelius states that "No one loses the past or the future, for no man can be derived of what he does not have" (Borges, Selected 227). 


\section{CONCLUSION}

The relations between the hegemonic and the subaltern, the colonizer and the colonized, were under an intense revision in the second half of the twentieth century. Edward Said, Michel Foucault, Albert Memmi, and many others - as Magali Carrera defines it - contributed to the shift in scholarly thinking and redefinition of the concept of colonialism, the perception of which shifted from a static to dynamic, making it an active mechanism of construction of the Western history (15). The present research constitutes a systematic analysis of the development of a dynamic Hispanic Orientalist paradigm across space and time. It is focused on the Orientalizing practices and mechanisms adopted by the hegemonic part of Hispanic society, first in Medieval Iberia

and Renaissance Spain, then in its spatial transition to Colonial Latin America, and finally in its temporal displacement toward Independence and Latin American modernity. This broad approach reveals gradual and subtle changes that occurred over the years and influenced or altered the original paradigm. It is important to emphasize that the authors of the texts analyzed for each of the four stages of development of Hispanic Orientalism generally belong to the dominant sociocultural group. Therefore, the patterns and the mechanisms found in those texts depict the evolution of hegemonic Hispanic Orientalism. Parallel to this narrative is the so-called narración de los vencidos, the narrative of the vanquished, the subaltern, the Other. Such texts were purposefully omitted in the present research for the sake of consistency in point of view.

Four stages proved to be crucial for the development of Hispanic Orientalism. The original paradigm was coined in Medieval Iberia and Renaissance Spain during the 
first significant encounter with the Semitic Other, the Moors and the Jews. As a threat to the nascent Spanish kingdom, both groups went through a process of reinvention by hegemonic society. The lesser a threat they became, the more distant these two Others became from their historical portrait, in other words, the more idealized. It is also significant that their initial mode of Orientalization differed. While the Moors were included in the Christian-Muslim dichotomy, the Jews were marginalized or excluded from this social construction. Hence, the Muslim Other underwent a process of reinvention for the sake of being neutralized through its appropriation, while the Jewish Other was reinvented in order to be placed outside the social order, and therefore neutralized as a threat nonetheless. By the end of the Reconquest, the Orientalist paradigm was well established and did not meet any significant resistance in its overseas journey.

The early Colonial period marks the second stage in the development of Hispanic Orientalism. It is generally accepted that the Colonial enterprise was a logical continuation of the Christian Reconquest crusade in the Peninsula. It set a precedent not only for the treatment of the Amerindians, but any Other at the time. It is rooted in the fact that in the European imagination, the descendants of the Moors were only partly defined by their religion; more importantly, they were outsiders, non-Europeans, tainted by their religious "impurity." For the expanding Euro-American sense, the colonial minorities (Native Americans, Africans, Jews, and mestizo population) became the metaphoric and the symbolic descendants of the Moors (Majid 5). Hispanic Orientalism in the Americas set in motion an othering mechanism that affected the perception of the subaltern cultural self well into the Independence period. 
Indeed, the first chronicles of conquest and discovery reveal zealous attempts on the part of their authors not only to Orientalize the New World but to find the true Orient in it. However, the more information and the faster it penetrated Old Europe, the harder it was for hegemonic society to convince its audience of the veracity of the reinvented Other and its Oriental ties. The ideological and the tactic parallels between significant historical events, like the fall of Granada and the conquest of Aztec Empire, when conversion and education were used as offensive mechanisms, fueled the Orientalist theories calling for similarities between Moriscos and Amerindians (Majid 66). However, both curiosity on the part of the colonizer and the attempts on the part of colonized to manifest themselves as independent subjects, led to the implementation of a new Orientalist approach. The traditional trio of the conquistadors, to paraphrase Michael Householder's study Inventing Americans in the Age of Discovery, "encounter, invention, narration" gave way to "encounter, reinterpret and appropriate" (1). It seems that the shift from reinvention to reinterpretation for the purpose of appropriation is insignificant. It involves a substantial change in the approach to the Other. It requires a more meaningful and extensive dialogue between hegemonic and subaltern cultures.

This dialogue intensifies during the third stage, the late Colonial and the early Independence periods. Political and social instability were reflected in the transitional character of Hispanic Orientalism during this time. It combines the traditional appropriation approach to the Other (as seen in such typical hegemonic representations as those of the castas paintings) with the more novel approach -that of differentiation through self-Orientalization and the revalorization of the Other, instigated by the Independence movement. 
This leads to hispanismo, the reconciliation and the revalorization of Spanish heritage in the Americas, as Civantos defines it (27), as well as a more global reconciliation with the general Other, be it the Orient per se, as in the works of Borges or even Europe, as in the works of Enrique Gómez Carrillo. This marks the last, modern stage of Hispanic Orientalism that gravitates towards self-Orientalization as a means of recognizing its own uniqueness through self-differentiation from the metropolis, as well as from the rest of the world.

Modern Hispanic Orientalism came to life as a consequence of the successful struggle for independence in Latin America. It was defined by the shift in political power, as well as the change in cultural hegemony. In this sense, it can be correlated with another term describing the relationship of colonizer and colonized in Latin America, tropicalismo. The latter is also based on Eurocentric ideology as it exoticizes the primitive aboriginal Other; and yet, at the same time, it allows for multiple perspectives (Aparicio, and Chávez-Silverman 1-9). Such approximation (as does Hispanic Orientalism) produces in the mind of hegemonic society tainted with the fear of the Other, an image of 'mythical latinidad' (Nagy-Zekmi 18). This Orientalized image is the one that the newly independent Latin American nations try to rescue through differentiation from the colonial hegemonic discourse.

The task of establishing the developmental path of hegemonic Hispanic Orientalism throughout the history of the Hispanic world is challenging and can face significant skepticism and even criticism because of its broad nature. It is almost unrealistic to analyze all the manifestations of this phenomenon in Spanish and Latin American literature and culture. However, it was never the purpose of the present 
research to delineate an exhaustive picture of Hispanic Orientalism, but rather to reveal the dominant tendencies and landmark moments in its overall evolution, as well as to shed light on the underlying causes for these changes. Our first hypothesis stated that the paradigm was not static, and that historical forces and its migration from Spain to Latin America brought about its most significant changes. The textual corpus selected for this research serves as a litmus test that unveils this changing nature in Hispanic Orientalism. Across time and space, it proved to be a developing phenomenon defined by everchanging social strategies often in the face of political and religious turmoil. The shift in hegemonic power, be it the successful conclusion of the Spanish Reconquest, the Conquest of America, or the Independence movement that led to the Colony's separation from the metropolis, proved to be the engine of change within the original paradigm of Hispanic Orientalism. It reacted to changes in the official discourse of power by adapting to it through the process of mimicry implied in Said's concept of Orientalism. Therefore, a true model of Hispanic Orientalism arises only as a result of analyzing this changing paradigm.

Our second hypothesis, that the model of Hispanic Orientalism reflects sociopolitical processes and, as a result, contains a number of characteristics pertinent to a specific type of discourse (e.g., imperial or non-imperial) was also confirmed. It was reflected in the predominance of certain Orientalist approaches during different time periods. For instance, during the stages when the imperial discourse of power was in play, Hispanic Orientalism revealed a marked tendency toward the appropriation of the Other through various mechanisms, like reinvention or reimagination and reinterpretation. This echoes the negative view of Orientalism by Edward Said, who 
critiqued the preconceived and stereotypical image of the Other created by the hegemonic sociopolitical group.

At the same time, in early Independence and into modernity, an era dominated by the non-imperial discourse of power, the leading Orientalist approach is based on the process of differentiation and self-Orientalization, as argued, among others, by Julia Kushigian. Unlike the imperial discourse, the non-imperial discourse is based on juxtaposition, not on hierarchy. This interaction among adjacent powers, each of them trying to dominate the other culturally, politically, or economically, amplified the need to rethink oneself in comparison to the often pre-established images of the Other(s), like early modern Europe had done, in order to confirm one's validity and importance in the world's political arena. Hence, Hispanic Orientalism does not entirely follow either one of the above mentioned theories. Both of them exhibit certain limitations in their approach: Said's Orientalism is based on nineteenth-century British and French Oriental policies in Africa, while Kushigian's argument is centered on modernity; her theory based on the sincere veneration of the Other by hegemonic society cannot be entirely applied to the manipulative strategies of the dominant sociocultural group during the preIndependence period.

In a way, Said's and Kushigian's approach to Orientalism seem to be most appropriate to describe the initial and the final stages in the development of the Hispanic Orientalist paradigm. Said's universal approach, in the words of Debra Lee-DiStefano, is an invitation to begin the dialogue of cultures (17-18). At the same time, Kushigian's approach is closely related to the process of gaining independence in Latin America and the weakening of the religious factor in a post-colonial context, when the newly formed 
states attempted to raise awareness of their uniqueness by differentiating themselves from the former metropolis and the rest of the world. Their independence from Spain allowed them to have the upper hand in negotiating their own identity, something that was rather impossible during the Colonial period. Only in this case, when the threat of the Other, either political or cultural, is diminished, can Hispanic Orientalism gradually become positive in its portrayal of the Other. By "positive" here I mean a greater and more sincere appreciation of the Other, as evidenced in much (although by no means all) of the literature from post-Independence into modernity, rather than reinventing the Other, as was the mark of Hispanic imperial Orientalism during the Reconquest, Conquest, and Colonial enterprises.

Born in Iberia, Hispanic Orientalism came a long way not only geographically but also structurally. It changed along with the discourse of power. Appropriation through reinvention and reinterpretation gave way to a more open-minded and open-ended, but nevertheless Orientalizing, mechanism: differentiation through self-Orientalization and revalorization of the Other(s), its history and culture. Yet, after all the changes that Hispanic Orientalism embraced, one question still remains: is there a Hispanic Orientalism or is there instead a multitude of Orientalist discourses in the Hispanic tradition? The answer to this question lies in the approach to the analysis on Hispanic Orientalism in this work. It focuses on the texts produced by the mainstream culture of the different periods. It does not provide a definitive answer to the question, as posed by Christina Civantos: "Can the subaltern speak in a language that will be listened to?" (222). Hispanic Orientalism did produce - from the first literary works in Spain and the folios of the Láminas Granatenses (Sacromonte Lead Books ${ }^{140}$ ) to modern cultural 
productions on both sides of the Atlantic — an Orientalist discourse by the Other, as well as attempts by hegemonic society to give a voice to the Other (not to be confused with the attempts by the same society to purposefully reinvent the Other): These are some of the other avenues of Hispanic Orientalist inquiry that were only delineated in this work and will constitute a topic for future research. Given the ample literary and artistic production featuring Orientalist practices, I recognize the limitations of such study and the impossibility to describe the phenomenon in all its variations. Therefore, the paradigm described here attempts to reflect Hispanic Orientalism as produced by the hegemonic group, as a first step in the analysis of the complex nature of Hispanic Orientalism.

Hispanic Orientalism came a long way from the alienation of the Other to its idealization and appropriation, and finally, to the differentiation from the Other by the Orientalized self. Along the way, it was used as a tool for colonialism, political propaganda, domination, and self-revalorization. Subject to political and sociocultural influences, it evolved along with the dominant discourse of power. Presently, new political circumstances - such as unprecedented migrations, the election of the first Jesuit and first Latin American Pope, Francis, his new politics of making Catholicism more embracing and accessible, as well as the reconfiguration of the old alliances in and between the Old and the New Worlds - will undoubtedly reflect in the discourse of Hispanic Orientalism in the years to come. 


\section{NOTES}

${ }^{140}$ See: García-Arenal, Mercedes, and Fernando Rodríguez Mediano. The Orient

in Spain: Converted Muslims, the Forged Lead Books of Granada, and the Rise of Orientalism. Trans. Consuelo López-Morillas. Boston, Leiden: Brill, 2013. Print. 


\section{BIBLIOGRAPHY}

Abellán, José Luis. “1492-1992.” El País. 1 Apr. 1993. Web. 31 Aug. 2010. $<$ http://www.elpais.com/articulo/opinion/1492-1992/elpepiopi/19930104elpepiopi_12 $/$ Tes $>$.

Acaso, Francisco. Historia y poesía del Cid Campeador. Madrid: Fenicia, 1971. Print.

Aguirre Beltrán, Gonzalo. La población negra de México: Estudio etnohistórico. Mexico City: Fondo de Cultura Económica, 1989. Print.

Alemán, Nicolás. "The Expulsion of Muslims and Jews in Don Quixote and the Picaresque of the Sixteenth Century." One World Periphery Reads the Other: Knowing the "Oriental" in the Americas and the Iberian Peninsula. Ed. Ignacio López-Calvo. Newcastle upon Tyne: Cambridge Scholars Publishing, 2010. 232- 43. Print.

Álvar, Manuel. El Romancero. Tradicionalidad y pervivencia. Barcelona: Planeta, 1970. Print.

Anonymous. De china y mulato produce gibarao. 1790-1800?. Oil on canvas. Private collection (Mexico).

Anonymous. De español y mulata, morisco. 1765?. Oil on canvas. Denver Art Museum, Denver (USA).

Anonymous. Descripción del Estado político de la Nueva España. N. d. MS 9-4799, fol. 367г. Real Academia de Historia, Madrid, Spain.

Anonymous. Las castas. 18th cent. Oil on canvas. Museo del Virreinato, Tepotzotlán (Mexico).

Aparicio, Frances R., and Susana Chávez-Silverman, eds. Introduction to Tropicalizations. Transcultural Representations of Latinidad. Ed. Frances R. Aparicio and Susana Chávez-Silverman. Hanover: U P of New England for Dartmouth College, 1997. 1-20. Print.

Araújo, Helena. "El modelo mariano, tema y variaciones.” Eco 248 (1982): 119-25. Print.

Arenal, Elena. Introdución. Neptúno alegórico. By Sor Juana Inés de la Cruz. Madrid: Cátedra, 2009. Print. 
Aristotle. The Politics. Trans. H. Rackham. Cambridge: Harvard UP; London: William Heinemann Ltd., 1944. Print. Vol. 21 of Works, gen. ed. 23 vols. 1944-1945.

Armstrong, Karen. Islam. A Short History. New York: Modern Library Edition, 2000. Print.

Bandera Gómez, Cesáreo. El "poema de mío Cid”: Poesía, Historia, Mito. Biblioteca románica hispánica. Madrid: Gredos, 1969. Print.

Barragán-Erkhause, Roselia. "Borges, Ararou and the Other: An Intercultural Study." Peripheral Transmodernities: South-to-South intercultural dialogues between the Hispanic World and "the Orient." Ed. Ignacio López-Calvo. Newcastle upon Tyne: Cambridge Scholar Publishing, 2012. 282-97. Print.

Barreda y Ordóñez, Ignacio María. 13. De chino y genízara albarazado. 1777. Oil on canvas. Real Academia Española, Madrid (Spain). Las Castas Mexicanas: Un género pictórico americano. Ed. María Concepción García Sáiz. Milan: Olivetti, 1989. 141. Print.

Barrueto, Jorge. "El indio en las tarjetas postales: metáforas visuales del miedo y la ansiedad política en Latinoamérica." Moros En La Costa: Orientalismo en Latinoamérica. Ed. Silvia Nagy-Zekmi. Madrid: Iberoamericana, 2008. 41-67. Print.

Baudot, Georges. Utopia and History in Mexico: The First Chroniclers of Mexican Civilization (1520-1569). Trans. Bernard R. Ortiz de Montellano and Thelma Ortiz de Montellano. Niwot: U P of Colorado, 1995. Print.

Berardini, Susan P. "La isla amarilla: (Re)visión and Subversion of the Discovery." $A$ Twice-Told Tale: Reinventing the Encounter in Iberian/Iberian American Literature and Film. Ed. Santiago Juan-Navarro and Theodore R. Young. Newark: U of Delaware P; London: Associated U P, 2001. 275-85. Print.

Berrueco, Luis. No te entiendo con india, sale chino. 1740?. Oil on canvas. Private collection, Palma de Mayorca (Spain).

Blanchard-Demouge, Paula. Introducción. Guerras civiles de Granada. Primera parte. By Ginés Pérez de Hita. Madrid: Imp. de E. Bailly- Baillière, 1913. vii-lxxxvi. Microfilm.

---. Introducción. Guerras civiles de Granada. Segunda parte. By Ginés Pérez de Hita. Madrid: Imp. de E. Bailly- Baillière, 1915. vii-xxxi. Microfilm.

Blanks, David R., and Michael Frassetto. Western Views of Islam in Medieval and Early Modern Europe: Perception of the Other. New York: St. Martin's P, 1999. Print. 
Booth, Wayne. The Rhetoric of Fiction. Chicago: U Of Chicago P, 1983. Print.

Borges, Jorge Luis. Collected Fictions. Trans. Andrew Hurley. New York: Penguin Books, 1998. Print.

---. Ficcionario. Ed. Emir Rodríguez Monegal. Mexico D. F.: Fondo de cultura económica, 1992. Print.

---. Selected Non-Fictions. Trans. Esther Allen, Suzanne Jill Levine, and Elliot Weinberger. New York: Viking, 1999. Print.

Browne, Walden. Sahagún and the Transition to Modernity. Norman: U of Oklahoma P, 2000. Print.

Bryant, Shasta. Introduction. Guerras civiles de Granada. Primera Parte. By Ginés Pérez de Hita. Newark: Juan de la Cuesta, 1982. ix-xxiv. Print.

Cabrera, Miguel. Casta Painting. 4-5. 1763. Oil on canvas. Private collection (Mexico).

---. Casta Painting. 9. 11. 1763. Oil on canvas. Museo de América, Madrid (Spain).

Camayd-Freixas, Erik. Etnografia imaginaria. Guatemala: F\&G Editores, 2012. Print.

---. Realismo mágico y primitivismo: Relecturas de Carpentier, Asturias, Rulfo y García Márquez. Lanham: U P of America, 1998. Print.

---. "The Orientalist Controversy and the Origins of Amerindian Culture." Orientalism and Identity in Latin America: Fashioning Self and Other from the (Post)Colonial Margin. Ed. Erik Camayd-Freixas. Tucson: U of Arizona P, 2013. 1-18. Print.

---. "The Tao of Mexican Poetry: Tablada, Villaurrutia, Paz." Orientalism and Identity in Latin America: Fashioning Self and Other from the (Post) Colonial Margin. Ed. Erik Camayd-Freixas. Tucson: U of Arizona P, 2013. 119-44. Print.

Capitulation of Granada. Trans. L. P. Harvey. Medieval Iberia: Readings from Christian, Muslim, and Jewish Sources. Ed. Olivia Remie Constable. Philadelphia: U of Pennsylvania P, 1997. 344-50. Print.

Carman, Glen. Rhetorical Conquests: Cortés, Gómara, and Renaissance Imperialism. West Lafayette: Purdue U P, 2006. Print.

Carrera, Magali M. Imagining Identity in New Spain: Race, Lineage and the Colonial Body in Portraiture and Castas Paintings. Austin: U of Texas P, 2003. Print. 
Chang Shik, León. "El espacio asiático concebido y vivido en las crónicas deJosé Juan Tablada." Orientalismos: Oriente y Occidente en la literatura y las artes de España e Hispanoamérica. Ed. Joan Torres-Pou. Barcelona: PPU, 2010. 91-. 102. Print.

Chimalpahin Cuauhtlehuanitzin Muñón, Domingo Francisco de San Antón. Chimalpahin's Conquest: A Nahua Historian's Rewriting of Francisco López De Gómara's La conquista de México. Ed. and trans. Susan Schroeder, Anne J. Cruz, Cristián Roa-de-la-Carrera, and David E. Tavárez. Stanford: Stanford U P, 2010. Print.

Civantos, Christina. Between Argentines and Arabs: Argentine Orientalism, Arab Immigrants, and the Writing of Identity. Albany: State U of New York P, 2006. Print.

---. "Orientalism Criollo Style: Sarmiento's 'Orient' and the Formation of an Argentine Identity." Orientalism and Identity in Latin America. Fashioning Self and Other from the (Post)Colonial Margin. Ed. Erik Camayd-Freixas. Tucson: U of Arizona P, 2013.44-61. Print.

Clapera, Francisco. Castas paintings. 1. 4-5. 8. 12-15. 1775. Oil on canvas. Denver Art Museum, Denver (USA).

Clark, Zoila. "Enrique Gómez Carillos' Japan and Latin American (Peripheral) Orientalism." Orientalism and Identity in Latin America: Fashioning Self and Other from the (Post) Colonial Margin. Ed. Erik Camayd-Freixas. Tucson: U of Arizona P, 2013.108-18. Print.

Codex Mendoza. Ed. James C. Clarke. 3 vols. London: n. p., 1938. Print.

Cohen, J. M. The Four Voyages of Christopher Columbus: Being His Own Log-Book, Letters and Dispatches with Connecting Narrative Drawn from the Life of the Admiral by His Son Hernando Colon and Other Contemporary Historians. Harmondsworth: Penguin, 1969. Print.

Colón, Cristobal. Los cuatro viajes del almirante y su testamento. Ed. Ignacio B. Anzoátegui. Buenos Aires: Espasa Calpe, 1946. Print.

Columbus, Christopher. The Diario of Christopher Columbus's First Voyage to America, 1492-1493. Trans. Oliver C. Dunn and James E. Kelley, Jr. Norman: U of Oklahoma $\mathrm{P}, 1989$. Print.

Cortés, Hernán. Cartas de relación. México: Editorial Porrúa, 1973. Print.

---. Letters from Mexico. New York: Grossman Publishers, 1971. Print. 
Cortina, Guadalupe. Invenciones multitudinarias: escritoras jadiomexicanas contemporáneas. Newark: Juan de la Cuesta, 2000. Print.

Cruz García, Ana. Re(de-)generando identidades: Locura, femenidad y liberalización en Elena Garro, Susana Pagano, Ana Castillo y María Amparo Escandón. Bern, Peter Lang, 2009. Print.

Cummins, John G., trans. The Voyage of Christopher Columbus: Columbus's Own Journal of Discovery. By Christopher Columbus. New York: St. Martin's P, 1992. Print.

Daniel, Norman. The Arabs and Medieval Europe. London: Longman; Beirut: Librairie du Liban, 1975. Print.

---. Islam and the West; the making of an Image. Edinburgh: Edinburgh U P, 1966. Print.

De Chasca, Edmund. The Poem of the Cid. Boston: Twayne Publishers, 1976. Print.

De la Cruz, Sor Juana Inés. Obras completas. 7th ed. Mexico: Editorial Porrúa, 1989. Print.

---. Sor Juana Inés De La Cruz: Selected Writings. Ed. Pamela Kirk Rappaport. New York: Paulist Press, 2005. Print.

De Sena, Isabel. "Beduinos en la pampa: el espejo oriental de Sarmiento." Moros en la costa: Orientalismo en Latinoamérica. Ed. Silvia Nagy- Zekmi. Madrid: Iberoamericana, 2008. 69-89. Print.

Deans-Smith, Susan. "Creating the Colonial Subject: Casta Paintings, Collectors, and Critics in Eighteenth-Century Mexico and Spain." Colonial Latin American Review 14.2 (2005): 169-204. Print.

Deferrari, Henry Austin. The Sentimental Moor in Spanish Literature before 1600. Philadelphia: U of Pensylvania P, 1927. Print.

Díaz del Castillo, Bernal. Historia verdadera de la conquista de la Nueva España. 3rd. ed. México: Editorial Patria, 1983. Print.

---. The True History of the Conquest of Mexico. Ann Arbor: University Microfilms, 1966. Print.

Duggan, Joseph J. The Cantar De Mio Cid: Poetic Creation in Its Economic and Social Contexts. Cambridge: Cambridge U P, 1989. Print. 
Etemad, Bouda. Possessing the World: Taking the Measurements of Colonisation from the Eighteenth to the Twentieth Century. Trans. Andrene Everson. New York: Berghahn Books, 2007. Print.

Fieldhouse, D. K. The Colonial Empires: A Comparative Survey from the Eighteenth Century. New York: Delacorte P, 1967. Print.

Flint, Valerie I. J. The Imaginative Landscape of Christopher Columbus. Princeton: Princeton U P, 1992. Print.

Foucault, Michel. Les mots et les choses: Une archéologie des sciences humaines. Paris: Gallimard, 1966. Print.

Gallo, Rubén. "Mexican Orientalism." Review: Literature and Arts of the Americas 39.1 (2006). 60-73. Print.

García-Arenal, Mercedes, and Fernando Rodríguez Mediano. The Orient in Spain: Converted Muslims, the Forged Lead Books of Granada, and the Rise of Orientalism. Trans. Consuelo López-Morillas. Boston, Leiden: Brill, 2013. Print.

García Sáiz, María Concepción. Las castas mexicanas: Un género pictórico americano. Milan: Olivetti, 1989. Print.

Garro, Elena. La Semana de colores. México, D.F: Editorial Grijalbo, 1989. Print.

Gasior, Bonnie L. "Castas Paintings." Africa and the Americas: Culture, Politics, and History. Ed. Richard M. Juang and Noelle A. Morrissette. 3 vols. Santa Barbara, California: ABC-CLIO, 2008. Print.

Gil, Juan, and Consuelo Varela. Cartas de particulares a Colón y relaciones coetáneas. Madrid: Alianza Editorial, 1984. Print.

Gómez Carrillo, Enrique. El Japón heroico y galante. Madrid: Mundo latino, 1920. Print. Vol. 7 of Obras completas, gen. ed. 7 vols. 1920.

---. Evocación de Guatemala. Crítica. Guatemala: Editorial del Ministerio de Educación Pública, 1954. Print. Vol. 1 of Páginas escogidas, gen. ed. 3 vols. 1954.

---. Impresiones de viajes. Guatemala: Editorial del Ministerio de Educación Pública, 1954. Print. Vol. 2 of Páginas escogidas, gen. ed. 3 vols. 1954.

---. La Rusia oriental. Paris: Garnier Hermanos, 1906. Print.

---. Literatura extranjera: estudios cosmopolitas. Paris: Garnier Hermanos, 1895. Print. 
---. Literaturas exóticas. Madrid: Mundo Latino, 1920. Print.

González, Cristina. "El conflicto entre el héroe y el rey en el Poema de Mio Cid y en el libro del Cavallero Zifar." Studies on Medieval Spanish Literature in Honor of Charles F. Fraker. Madison: Hispanic Seminary of Medieval Studies, 1995. 178-82. Print.

González, Michelle A. Sor Juana: Beauty and Justice in the Americas. Maryknoll: Orbis Books, 2003. Print.

Gonzalez, Patricia. "Protagonistas de Elena Garro: mujeres acuosas, viajeras míticas, tristes rebeldes." Los colores de la memoria: Percepciones sobre Elena Garro. Ed. Alicia V. Ramírez Olivares, Patricia Rosas Lopátegui, and Alejandro Palma Castro. Puebla: Benemérita Universidad Autónoma de Puebla, Facultad de Filosofía y Letras, 2007. 77-86. Print.

González Hernández, Cristina. Doña Marina (la Malinche) y la formación de la identidad mexicana. Madrid: Ediciones Encuentro, 2002. Print.

González López, Emilio. Historia De La Literatura Española. New York: Las Americas Pub. Co, 1962. Print.

González Palencia, Ángel. Moros y cristianos en España medieval. Madrid: Consejo Superior de Investigaciones Científicas, Instituto Antonio Nebrija, 1945. Print.

Gosser-Esquilín, Mary Ann. “Ana Lydia Vega’s Falsas crónicas del Sur: Reconstruction and Revision of Puerto Rico's Past." A Twice-Told Tale: Reinventing the Encounter in Iberian/Iberian American Literature and Film. Ed. Santiago Juan-Navarro and Theodore R. Young. Newark: U of Delaware P; London: Associated U P, 2001. 193209. Print.

Goyogana, Francisco M. Sarmiento y el laicismo: Religión y política. Buenos Aires, Argentina: Claridad, 2011. Print.

Guamán Poma de Ayala, Felipe. Nueva crónica y buen gobierno. Ed. John V. Murra, Rolena Adorno, and Jorge L. Urioste. 3 vols. Madrid: Historia, 16. 1987. Print.

Guerra Cunningham, Lucía. Splintering Darkness: Latin American Women Writers in Search of Themselves. Pittsburg: Latin American Review P, 1990. Print.

Guillén, Claudio. "Literature as Historical Contradiction: El Abencerraje, the Moorish novel, and the Eclogue." Literature as System: Essays Toward the Theory of literary History. Princeton: Princeton U P, 1971. 159-217. Print. 
Gutiérrez, José Ismael. "Dos acercamientos a un motivo literario de fin de siglo: La Salome de Oscar Wilde y la de Enrique Gómez Carrillo." Hispanic Review 63.3 (1995): 411-31. Print.

Guzauskyte, Evelina. "Fragmented Borders, Fallen Men, Bestial Women: Violence in the Casta Paintings of Eighteenth-century New Spain." Bulletin of Spanish Studies 86.2 (2009): 175-204. Print.

Haring, Clarence Henry. The Spanish Empire in Americas. New York: Oxford U P, 1947. Print.

The Holy Bible. The Berkley Version in Modern English. Ed. Gerrit Verkuyl. Grand Rapids: Zondervan Publishing House, 1959. Print.

The Holy Quran. Ed. Muhammad Said Al-Roushd. Tehran: International Publishing Co., 2001. Print.

Householder, Michael. Inventing Americans in the Age of Discovery: Narratives of Encounter. Burlington: Ashgate, 2011. Print.

Hubert, Rosario. "Rewriting Travel Literature: A Cosmopolitan Critique of Exoticism in Contemporary Latin American Fiction." Peripheral Transmodernities: South-toSouth intercultural dialogues between the Hispanic World and "the Orient." Ed. Ignacio López-Calvo. Newcastle upon Tyne: Cambridge Scholar Publishing, 2012. 42-61. Print.

Iglesia, Ramón. "Las críticas de Bernal Díaz del Castillo a la Historia de la conquista de México, de López de Gómara." El hombre Colón y otros ensayos. México: El Colegio de México, 1944. 77-96. Print.

Islas, Andrés de. Casta Painting. 4-5. 8. 10. 13. 1774. Oil on canvas. Museo de América, Mardid (Spain).

Jardine, Alice. Gynesis: Configuration of Women and Modernity. Ithaca: Cornell U P, 1985. Print.

Kabbani, Rana. Europe's Myths of Orient. Bloomington: Indiana U P, 1986. Print.

Kamen, Henry. Spain, 1469-1714: A Society of Conflict. London: Longman, 1991. Print.

Kaplan, Marina. "The Latin American Romance in Sarmiento, Borges, Ribeyro, Cortázar, and Rulfo." Sarmiento, Author of a Nation. Ed. Tulio Halperín Donghi et al. Berkeley: U of California P, 1994. 314-46. Print. 
Katra, William H. "Reading Viajes: Race, Identity, and National Destiny." Sarmiento, Author of a Nation. Ed. Tulio Halperín Donghi et al. Berkeley: U of California P, 1994. 73-100. Print.

Katzew, Ilona. Casta Paintings: Images of Race in Eighteenth-Century Mexico. New Haven: Yale U P, 2004. Print.

Kedar, Benjamin Z. Crusade and Mission: European Approaches toward the Muslims. Princeton: Princeton U P, 1984. Print.

Kinross, Patrick B. The Ottoman Centuries: The Rise and Fall of the Turkish Empire. New York: Morrow, 1977. Print.

Kodama, María. Foreword. Borges and Memory. By Rodrigo Quian Quiroga. Borges and Memory: Encounters with the Human Brain. Cambridge: MIT P, 2012. Print.

Kushigian, Julia. "El Primero sueño y Las mil y una noches: Sor Juana Inés de la Cruz, orientalista." Moros En La Costa: Orientalismo en Latinoamérica. Ed. Silvia NagyZekmi. Madrid: Iberoamericana, 2008. 167-86. Print.

---. Orientalism in the Hispanic Literary Tradition: in Dialogue with Borges, Paz, and Sarduy. Albuquerque: U of New Mexico P, 1991. Print.

Lacoue-Labarthe, Philippe. Typography: Mimesis, Philosophy, Politics. Ed. Christopher Fynsk. Cambridge: Harvard U P, 1989. Print.

Ladd, Doris M. The Mexican Nobility at Independence, 1780-1826. Austin: U of Texas at Austin Institute of Latin American Studies, 1976. Print.

Lama, de Victor, and Emilio Peral Vega. El Abencerraje y la Hermosa Jarifa. Madrid: Castalia, 2000. Print.

Lamar Prieto, Covadonga. "El criollismo de José de Eguiara y Eguren en los Prólogos a la biblioteca mexicana." Centro y periferia: Cultura, lengua y literatura virreinales en América. Ed. Claudia Parodi and Jimena Rodríguez. Madrid: Iberoamericana, 2011. 79-90. Print.

Lee-DiStefano, Debra. "Theory, Orientalism and a Perspective on Their Place in the Study of Asians in the Americas." Peripheral Transmodernities: South-to-South intercultural dialogues between the Hispanic World and "the Orient." Ed. Ignacio López-Calvo. Newcastle upon Tyne: Cambridge Scholar Publishing, 2012. 12-22. Print. 
Lehman, Sara L. Sinful Business: New World Commerce as Religious Transgression in Literature on and of the Spanish Colonies. Newark: Juan De La Cuesta, 2010. Print.

León, Nicolás. Las castas de México colonial o Nueva España; noticias etnoantropológicas. Mexico: Talleres gráficos del Museo Nacional de Arqueología, Historia y Etnografía, 1924. Print.

Léon Portilla, Miguel. Hernán Cortés y la mar del Sur. Madrid: Ediciones Cultura Hispánica, 1985. Print.

López-Baralt, Luce. Huellas de Islam en la literatura española. De Juan Ruiz a Juan Goytisolo. Mardid: Hiperion, 1985. Print.

López Estrada, Francisco, and John Esten Keller. Antonio de Villegas' El Abencerraje. Chapel Hill: The U of North Carolina P, 1964. Print.

López de Gómara, Francisco. Historia general de las Indias. Primera parte. Barcelona: Editorial Iberia, 1965. Print.

---. Historia general de las Indias. Segunda parte. Barcelona: Editorial Iberia, 1965. Print.

Lucena Salmoral, Manuel. Hernán Cortés: La espada de Quetzalcóatl. Madrid: Anaya, 1988. Print.

Lumsden-Kouvel, Audrey. "A Counter-Reformation Hero: 'The Saint and Martyr in Calderón's El príncipe constante.” Bulletin of Hispanic Studies 77.1 (2000): 101-10. Print.

MacLachlan, Colin M. Spain's Empire in the New World: The Role of Ideas in Institutional and Social Change. Berkeley: U of California P, 1988. Print.

Magaña, Sergio. Moctezuma II. Cortés y La Malinche. México: Editores Mexicanos Unidos, 1985. Print.

Magón, José Joaquín. 5. De español, y mulata, sale morisca. 1770?. Oil on canvas. Museo Nacional de Antropología, Madrid (Spain).

Majid, Anouar. We Are All Moors: Ending Centuries of Crusades against Muslims and Other Minorities. Minneapolis: U of Minnesota P, 2009. Print.

Mauro, Frédéric. La expansión europea (1600-1870). Barcelona: Labor, 1975. Print. 
Medieval Iberia: Readings from Christian, Muslim, and Jewish Sources. Ed. Olivia Remie Constable. Philadelphia: U of Pennsylvania P, 1997. Print.

Memmi, Albert. Decolonization and the Decolonized. Minneapolis: U of Minnesota P, 2006. Print.

Mendoza, Juan de. Enrique Gómez Carrillo. Estudio crítico-biográfico: su vida, su obra y su época. Vol. 2. Guatemala: n.p., 1946. Print.

Menéndez Pidal, Ramón. Cantar de Mio Cid, texto, gramática y vocabulario. Madrid: Imp. de E. Bailly- Baillière, 1908. Print. Vol. 1 of Cantar de Mio Cid, texto, gramática y vocabulario, gen. ed. 3 vols. 1908-1911.

---. En torno al Poema Del Cid. Barcelona: E.D.H.A.S.A, 1963. Print.

---. La lengua de Cristóbal Colón: El estilo de Santa Teresa: y otros estudios sobre el siglo XVI. Madrid: Espasa-Calpe, 1942. Print.

Menéndez y Pelayo, Marcelino. Orígenes de la novela. Madrid: Imp. de E. BaillyBaillière, 1905. Print. Vol. 1 of Nueva biblioteca de autores españoles, gen. ed. 4 vols. 1905-1915.

Menocal, María Rosa. The Arabic Role in the Medieval Literary History: a Forgotten Heritage. Philadelphia: U of Pennsylvania P, 1987. Print.

Merle, Marcel. "Presentación." El anticolonialismo europeo: Desde Las Casas a Marx. Eds. Marcel Merle, and Roberto Mesa. Madrid: Alianza, 1972. 13-51.Print.

Merrim, Stephanie. Early Modern Women's Writing and Sor Juana Inés De La Cruz. Nashville: Vanderbilt U P, 1999. Print.

Messinger Cypess, Sandra. La Malinche in Mexican Literature. From History to Myth. Austin: U of Texas P, 1991. Print.

---. "Myth and Metatheatre: Magaña's Malinche and Medea." Bucknell Review 40.2 (1996): 37-52. Print.

---. "The Figure of La Malinche in the texts of Elena Garro." A Different Reality: Studies on the Work of Elena Garro. Ed. Anita K. Stoll. Lewisburg, Bucknell U P, 1990. 11735. Print.

---. Uncivil Wars: Elena Garro, Octavio Paz, and the Battle for Cultural Memory. Austin: U of Texas P, 2012. Print. 
Metherd, Molly. "The Americanization of Christopher Columbus in the Works of William Carlos Williams and Alejo Carpentier." A Twice-Told Tale: Reinventing the Encounter in Iberian/Iberian American Literature and Film. Ed. Santiago JuanNavarro and Theodore R. Young. Newark: U of Delaware P; London: Associated U P, 2001. 227-42. Print.

Meyerson, Mark. "Socializing and Violence on Corpus Christi Day (1491)." Trans. Mark Meyerson. Medieval Iberia: Readings from Christian, Muslim, and Jewish Sources. Ed. Olivia Remie Constable. Philadelphia: U of Pennsylvania P, 1997. 338-40. Print.

Meyrán, Daniel. “'Los misterios del eco' o la expresión americana en busca de una memoria." América sin nombre 5-6 (2004): 164-70. Print.

Miles, Margaret R. Reading for Life: Beauty, Pluralism, and Responsibility. New York: Continuum, 1997. Print.

Mohammed, Ovey N. Muslim-Christian Relations: Past, Present, Future. Maryknoll: Orbis Books, 1999. Print.

Morán, Francisco. "Volutas del deseo: hacia una lectura del orientalismo en el modernismo hispanoamericano." MLN (Hispanic Issue) 120.2 (2005). 383-407. Print.

More, Anna. "Carlos de Sigüenza y Góngora y el archivo criollo en la Nueva España." Centro y periferia: Cultura, lengua y literatura virreinales en América. Ed. Claudia Parodi and Jimena Rodríguez. Madrid: Iberoamericana, 2011. 71-78. Print.

Morison, Samuel Eliot. Journals and Other Documents on the Life and Voyages of Christopher Columbus. New York: The Heritage P, 1963. Print.

Motolinía, Toribio. Motolinia's History of the Indians of New Spain. Trans. Francis Borgia Steck. Washington, D.C: Academy of American Franciscan History, 1951. Print.

---. Historia de los indios de la Nueva España: Relación de los ritos antiguos, idolatrías y sacrificios de los indios de la Nueva España, y de la maravillosa conversión que Dios en ellos ha obrado. Ed. Edmundo O'Gorman. 3rd ed. México: Editorial Porrua, 1979. Print.

"Mozarabic Refutation of Islam." Trans. Thomas E. Burman. Medieval Iberia: Readings from Christian, Muslim, and Jewish Sources. Ed. Olivia Remie Constable. Philadelphia: U of Pennsylvania P, 1997. 143-47. Print.

Mualem, Shlomy. Borges and Plato: A Game with Shifting Mirrors. Madrid: Iberoamericana, 2012. Print. 
Muntaner, Ramón. "Chronicle (1325-1328)." Trans. Anna Goodenough. Medieval Iberia: Readings from Christian, Muslim, and Jewish Sources. Ed. Olivia Remie Constable. Philadelphia: U of Pennsylvania P, 1997. 232-36. Print.

Nagy-Zekmi, Silvia. "Buscando el Este en el Oeste: Prácticas orientalistas en la literatura latinoamericana." Moros en la costa: Orientalismo en Latinoamérica. Ed. Silvia Nagy-Zekmi. Madrid: Iberoamericana, 2008. 11-21. Print.

Navagero, Andrea. "Description of Granada and the Alhambra in 1526." Ed. Shasta Bryant. Guerras civiles de Granada. Primera Parte. By Ginés Pérez de Hita. Newark: Juan de la Cuesta, 1982. 313-18. Print.

"Nubdhat al-'așr." Trans. L. P. Harvey. Medieval Iberia: Readings from Christian, Muslim, and Jewish Sources. Ed. Olivia Remie Constable. Philadelphia: U of Pennsylvania P, 1997. 350-51. Print.

O'Gorman, Edmund. The Invention of America. México: Cultura, 1992. Print.

Olivares Zorrilla, Rocío. "Los tópicos del sueño y del microcosmos: la tradición de Sor Juana Inés de la Cruz." Ed. José P. Buxó. Sor Juana Inés De La Cruz y las vicisitudes de la crítica. México: Universidad Nacional Autónoma de México, 1998. 179-211. Print.

Orellana, Margarita. "The Fever of the Image in Castas Painting." Artes de México: la Pintura de Castas. 8 (1990): 84-85. Print.

Pagden, A. R. "Hernán Cortés." Letters from Mexico. By Hernán Cortés. New York: Grossman Publishers, 1971. 39-67. Print.

Parodi, Claudia. "Fiestas palaciegas: sor Juana Inés de la Cruz y el Neptuno alegórico, Carlos Sigüenza y Góngora y el Teatro de virtudes políticas." Centro y periferia: Cultura, lengua y literatura virreinales en América. Ed. Claudia Parodi and Jimena Rodríguez. Madrid: Iberoamericana, 2011. 29-43. Print.

Parry, J. H. The Spanish Theory of Empire in the Sixteenth Century. Folcroft: Folcroft Library Editions, 1973. Print.

Paz, Octavio. El laberinto de la soledad. México: FCE, 1982. Print.

---. Sor Juana Inés de la Cruz o Las trampas de la fe. 6th ed. Barcelona: Seix Barral, 1998. Print.

Pérez de Hita, Ginés. The Civil Wars of Granada; and the History of the Factions of the Zegries and Abencerrajes, Two Noble Families of that City, to the Final Conquest by 
Ferdinand and Isabella. Trans. Thomas Rodd. London: J. Bonsor, 1803. Web. 30 Aug. 2010.

---. Guerras civiles de Granada. Primera Parte. Ed. Shasta Bryan. Newark: Juan de la Cuesta, 1982. Print.

---. Guerras civiles de Granada. Segunda parte. Ed. Paula Blanchard-Demouge. Madrid: Imp. de E. Bailly- Baillière, 1915. Microfilm.

Perrone, Charles. Letras e letras da música popular brasileira. Trans. José Luiz Paulo Machado. Rio de Janeiro: Elo Editora, 1988. Print.

Phillips, Wendy E. "Representation of the Black Body in Mexican Visual Art. Evidence of an African Historical Presence or a Cultural Myth?" Journal of Black Studies 39.5 (2009): 761-85. Print.

Pierce, Donna. Companion to Spanish Colonial Art at the Denver Art Museum. Denver: Mayer Center for Pre-Columbian \& Spanish Colonial Art at the Denver Art Museum, 2011. Print.

The Poem of The Cid (El Poema del Mio Cid). Trans. W. S. Merwin. London: J. M. Dent \& Sons LTD, 1959. Print.

Poema de mio Cid. Ed. Ramón Menéndez Pidal. Madrid: Espasa-Calpe, 1971. Print.

Quian Quiroga, Rodrigo. Borges and Memory: Encounters with the Human Brain. Trans. Juan Pablo Fernández. Cambridge: MIT P, 2012. Print.

Quinn, Mary B. The Moor and the Novel: Narrating Absence in Early Modern Spain. New York: Palgrave Macmillan, 2013. Print.

The Qur'an. Trans. Yusuf Ali Abdullah. Istambul: Asir Media, 2008. Print.

Ramos, Julio. Desencuentros de la modernidad en América Latina: Literatura y política en el siglo XIX. Santiago: Editorial Cuarto Propio, 2003. Print.

Read, Malcolm K. The Birth and Death of Language: Spanish Literature and Linguistics, 1300-1700. Madrid: J. Porrúa Turanzas, 1983. Print.

Real Academia Española. Diccionario de la lengua española. 22nd ed. Real Academia Española, n. d. Web. 20 May 2014.

Rico, Fernando. La novela picaresca y el punto de vista. Barcelona: Seix Barral, 1970. Print. 
Roa-de-la-Carrera, Cristián A. "Francisco López de Gómara and La conquista de México." Chimalpahin's Conquest: A Nahua Historian's Rewriting of Francisco López De Gómara's La conquista de México. Stanford: Stanford U P, 2010. 35-49. Print.

---. Histories of Infamy: Francisco López De Gómara and the Ethics of Spanish Imperialism. Trans. Scott Sessions. Boulder: U P of Colorado, 2005. Print.

Rocha, Cristina. "Zen in Brazil: Cannibalizing Orientalist Flows." Orientalism and Identity in Latin America: Fashioning Self and Other from the (Post)Colonial Margin. Ed. Erik Camayd-Freixas. Tucson: U of Arizona P, 2013. 200-16. Print.

Rodríguez Monegal, Emir, and Alastair Reid, eds. Borges a Reader. A Selection from the Writings of Jorge Luis Borges. Trans. Alastair Reid et al. New York: E. P. Dutton, 1981. Print.

Ruedas de la Serna, Jorge. "Sor Juana Inés de la Cruz en la visión de la crítica romántica mexicana." Ed. José P. Buxó. Sor Juana Inés De La Cruz y las vicisitudes de la crítica. México: Universidad Nacional Autonóma de México, 1998. 213-24. Print.

Said, Edward. Orientalism. New York: Vintage Books, 2003. Print.

Sánchez-Albornoz, Claudio. El Islam de España y el Occidente. Madrid: Espasa Calpe, 1974. Print.

Santovenia, Emeterio S. Sarmiento y su americanismo. Buenos Aires: Editorial Américaless, 1949. Print.

Sarmiento, Domingo Faustino. Facundo: civilización y barbarie. Caracas: Biblioteca Ayacucho, 1985. Print.

---. Facundo: Civilization and Barbarism. Trans. Kathleen Ross. Berkeley: U of California P, 2003. Print.

Schulman, Ivan A. "Narrating Orientalism in Spanish American Modernism." Orientalism and Identity in Latin America: Fashioning Self and Other from the (Post) Colonial Margin. Ed. Erik Camayd-Freixas. Tucson: U of Arizona P, 2013. 95-107. Print.

Sears, Theresa A. "Echado De Tierra": Exile and the Psychopolitical Landscape in the Poema De Mio Cid. Newark: Juan de la Cuesta, 1998. Print.

Smith, Roger R. "Restatement: A Technique of Oral Composition in the Poema de Mio Cid." Ed. Nicolas Toscano Liria. Estudios alfonsivos y otros escritos. New York: 
National Endowment for the Humanities, National Hispanic Foundation for the Humanities: 1991. 216-25. Print.

"Song of the Cid." Trans. Rita Hamilton. Medieval Iberia: Readings from Christian, Muslim, and Jewish Sources. Ed. Olivia Remie Constable. Philadelphia: U of Pennsylvania P, 1997. 111-17. Print.

Southern, R W. Western Views of Islam in the Middle Ages. Cambridge: Harvard U P, 1962. Print.

Stefano, Luciana de. La Sociedad Estamental De La Baja Edad Media Española a La Luz De La Literatura De La Época. Caracas: Universidad Central de Venezuela, Facultad de Humanidades y Educación, Instituto de Filología "Andrés Bello," 1966. Print.

Sullivan, Edward J. "A Visual Phenomenon of the Americas." Artes de México: la Pintura de Castas 8 (1990): 85-86. Print.

Sorensen, Diana. Facundo and the Construction of Argentine Culture. Austin: U of Texas P, 1996. Print.

Taboada, Hernán. La sombra del Islam en la conquista de América. México: Universidad Nacional Autónoma de México, 2004. Print.

Thomas, George Antony. The Politics and Poetics of Sor Juana Inés De La Cruz. Surrey, England: Ashgate, 2012. Print.

Tinajero, Araceli. Orientalismo en el modernismo americano. Purdue: Purdue U P, 2004.

Tissera, Ana. Borges y los mundos posibles, 1975-1985. Argentina: Ed. FFyh (UNC), Universitas, 2005. Print.

Tolan, John V. Saracens: Islam in the Medieval European Imagination. New York: Columbia UP, 2002. Print.

Torres, Edelberto. Enrique Gómez Carrillo. El cronista errante. Guatemala: Librería escolar: 1956. Print.

Toruño, Rhina. Tiempo, destino y opresión en la obra de Elena Garro. Lewiston: Mellen U P, 1996. Print.

Tunón de Lara, Manuel, et al. Historia de España. Valladolid: Ambito, 1999. Print.

Unamuno, Miguel, and Miramón A. Suárez. Niebla. Madrid: Alianza, 1986. Print. 
Valli, Giorgio. "Ludivico Ariosto y Ginés Pérez de Hita." RFE 30 (1946): 23-53. Print.

Verdevoye, Paul. "Viajes por Francia y Argelia." Viajes por Europa, África y América 1875-1847 y Diario de gastos. By Domingo Faustino Sarmiento. Ed. and comp. Javier Fernández. Buenos Aires: Fondo de cultura económica de Argentina, 1993. 689-715. Print.

Wagner, Henry R. "The Lost First Letter of Cortes." The Hispanic American Historical Review XXI (1941): 153-74. Print.

Weiss, Timothy. Translating Orients. Between Ideology and Utopia. Toronto: U of Toronto P, 2004. Print.

Whittingham, Giorgina J. "Japón de Hiroshigué en las pioneras innovaciones de Juan José Tablada." Moros en la costa: Orientalismo en Latinoamérica. Ed. Silvia NagyZekmi. Madrid: Iberoamericana, 2008. 217-31. Print.

Widdifield, Stacie. The Embodiment of the National in the Late Nineteenth-Century Mexican Painting. Tucson: U of Arizona P, 1996. Print.

Woscoboinik, Julio. The Secret of Borges: A Psychoanalytic Inquiry into His Work. Trans. Dora Carlisky Pozzi. Lanham: U P of America, 1998. Print.

Wright, Diana M. "Temas moriscos: Del romancero a la novela morisca." Ed. Nicolas Toscano Liria. Estudios alfonsivos y otros escritos. New York: National Endowment for the Humanities, National Hispanic Foundation for the Humanities: 1991. 254-61. Print.

Young, Theodore Robert. "Tropicalismo and How Tasty Was My Little Frenchman." A Twice-Told Tale: Reinventing the Encounter in Iberian/Iberian American Literature and Film. Ed. Santiago Juan-Navarro and Theodore R. Young. Newark: U of Delaware P; London: Associated U P, 2001. 80-88. Print.

Zaid, Rhona. "Las Guerras civiles de Granada: The Idealization of the Assimilation." Ed. John V. Tolan. Medieval Christian Perceptions of Islam: A Book of Essays. New York: Garland Pub, 1996. 313-30. Print.

Zepp, Evelyn. "Theories of the Feminine: Kristeva." Enclitic 4.2 (1981): 5-15. Print. 
VITA

\section{SVETLANA TYUTINA}

2004

2006

2009

2010

2014
B.A., Second Language Acquisition, Instructional Technology

Herzen State Pedagogical University of Russia

St. Petersburg, Russia

M.A., Spanish

University of Northern Iowa

Cedar Falls, Iowa

Ph.D. Candidate, Spanish

Florida International University

Miami, Florida

Ph.D., Romance Philology

Herzen State Pedagogical University of Russia

St. Petersburg, Russia

Assistant Professor

Florida Polytechnic University

Lakeland, Florida

\section{SELECTED PUBLICATIONS AND PRESENTATIONS}

1. "La visión del mestizaje en la segunda mitad del siglo XX: La reivindicación femenina y masculina de la Malinche.” El Cid, 2013. xxiv-xxxi. Web.

2. "Gallant, Heroic and Orientalized Japan in the Narrative of Enrique Gómez Carrillo." LASA Congress. Washington D.C., May 2013.

3. "Incorporating Language for Special Purposes into Traditional Language Courses." MLA Congress. Boston, MA, January 2013.

4. "Foreign Languages in the Modern Job Market: Languages for Special Purposes." Proceedings of the $5^{\text {th }}$ ICT Conference, Nov. 15-16, 2012. Padova: Libreria Universitaria Italiana, 2012. 371-376. Print.

5. "Cantar de mio Cid: Creation of the Founding Paradigm of Hispanic Orientalism." Peripheral Transmodernities: South-to-South intercultural dialogues between the Hispanic World and "the Orient." Newcastle upon Tyne: Cambridge Scholar Publishing, 2012. 178- 196. Print. 
6. "Graduate Student Leadership and Community Service. Graduate Student Professional Organizations: to Join or not to Join?" MLA Congress. Seattle, WA, January 2012.

7. "The Manifestation of Eurocentric Orientalism in Eighteenth-Century Castas Paintings (Mexican School)." $4^{\text {th }}$ Conference on Orientalisms and the Asian and Arab Diasporas: Representaciones del/de lo oriental en las Américas y en la Península Ibérica. U of Fez, Morocco, March 2012.

8. "La imagen de moro y morisco en la novela de Ginés Pérez de Hita Guerras civiles de Granada." Serta Hispanica. St. Petersburg: St. Petersburg Academy of Postgraduate Pedagogical Education P, 2012. 33-37. Print.

9. "Competitive Strategies of Spanish Newspaper in the Contemporary Information Space." Annual Conference of Russian Academy of Science "Society, Language, and Culture." Russian Academy of Science, Russian Academy of Language, Moscow Institute of Foreign Languages, Moscow, Russia, September 2011.

10. "Using Business Section of Spanish Newspapers in Spanish for Business Class." 12th Annual Spanish Language Faculty Development Program "Teaching Spanish for Business: A Global Approach." Ávila-Madrid, Spain, June 2011. 